REGIS CAVINI FERREIRA

\title{
RESPOSTAS AUTONÔMICAS E NEUROENDÓCRINAS À RECUPERAÇÃO DE MEMÓRIAS TRAUMÁTICAS
}

SÃo PAULO

2006

REGIS CAVINI FERREIRA 


\title{
RESPOSTAS AUTONÔMICAS E NEUROENDÓCRINAS À RECUPERAÇÃO DE MEMÓRIAS TRAUMÁTICAS
}

\author{
Tese apresentada ao Instituto de \\ Psicologia da Universidade de São Paulo \\ para a obtenção do título de Doutor.
}

Área de concentração:

Neurociências e Comportamento

Orientadora:

Profa. Dra. Antonia Gladys Nasello

SÃO PAULO

2006 
FOLHA DE APROVAÇÃO

Régis Cavini Ferreira

Respostas Autonômicas e Neuroendócrinas à

Recuperação de Memórias Traumáticas

Tese apresentada ao Instituto de

Psicologia da Universidade de São

Paulo para a obtenção do título de

Doutor.

Área de Concentração:

Neurociências e Comportamento

Aprovado em:

Banca Examinadora

Prof. Dr.

Instituição Assinatura

Prof. Dr.

Instituição Assinatura

Prof. Dr.

Instituição

Assinatura

Prof. Dr.

Instituição

Assinatura

Prof. Dr

Instituição Assinatura 
A Ciência é feita por nós.

Um trabalho científico é uma tentativa de desatar os nós. 


\section{GLADYS}

Por voltas que o mundo dá, conheci Gladys em Buffalo, EUA, em 1990, num congresso sobre Hormônios e Comportamento, da International Society of Psychoneuroendocrinology, quando então descobrimos que trabalhávamos na Faculdade de Ciências Médicas da Santa Casa de São Paulo há muitos anos, em diferentes departamentos, sem termos nos encontrado antes!

Coisas da vida.

Fui conhecendo Gladys aos poucos.

O respeito inicial pela cientista se transformou em admiração pela pessoa. Tempos depois, gentilmente, aceitou ser orientadora de meu doutorado. A admiração se transformou numa grande amizade a apoiar nos instantes precisos, a indicar caminhos e a abrir perspectivas, a dirimir dúvidas e a estimular tentativas.

Hoje, dezesseis anos depois, continuo como antes, numa séria dúvida: Gladys é um cérebro brilhante envolvendo um enorme coração, ou um enorme coração que envolve um cérebro brilhante?

Não sabendo distinguir entre as alternativas, fico dialeticamente com as duas.

Assim, à PROF ${ }^{\mathbf{a}}$. DR ${ }^{\mathrm{a}}$. ANTONIA GLADYS NASELLO, o mais profundo agradecimento por ter me ajudado a transformar um sonho em realidade. 


\section{DEDICATÓRIA}

Aos meus pais (in memoriam), João Evangelista Ferreira e Guilhermina Cavini Ferreira, fundamentos de meus valores, que sempre leram o que escrevi.

Ao meu irmão, Dr. Pedro Césare Cavini Ferreira, amigo e companheiro de caminhada.

Às minhas filhas, Ana Paula Varella Ferreira e Flávia Melissa Varella Ferreira, amorosos e permanentes estímulos à minha existência.

Pedro, essa é mais uma das nossas! 


\section{AGRADECIMENTOS}

Ao Prof. Dr. Carlos Humes Jr., pelo exemplo de toda uma vida seriamente dedicada ao ensino e à pesquisa.

Ao Dr. Eduardo de Castro Humes, pela madura e afetiva disponibilidade em ouvir e opinar.

Ao Prof. Dr. Geraldo Lino de Campos, pela amizade, exemplo e pelas periódicas, contundentes e pertinentes críticas.

À Dra. Juliane Prieto Peres Mercante, pelo gentil, desprendido e inestimável auxílio.

Ao Dr. Júlio Fernando Prieto Peres, pelo apoio, entusiasmo, fraterna amizade e permanente estímulo.

À Dr$^{\mathrm{a}}$. Maria Júlia Moraes de Prieto Peres, mestre e amiga, exemplo de disponibilidade e dedicação desprendida aos semelhantes, sem cuja presença em minha vida este trabalho não teria sido possível.

À Profa. Dra. Miriam Garcia, pelo inestimável auxílio no tratamento estatístico dos resultados.

Ao Dr. Wolf José Singal, por abrir portas e indicar caminhos.

Aos Professores do Programa de Pós-Graduação do IP/NEC/USP, pelo conhecimento transmitido.

À Ana Maria Godoy, pela revisão do texto deste trabalho. 
O Homem é feito de memórias.

Sem elas não tem referências e, portanto, não se vincula àquilo que lhe permite saber onde está, o que faz e nem mesmo imaginar quem é.

Lembro-me, pois.

Lembro-me que surpreendido num instante de minha trajetória por um lampejo de consciência, ousei colocar a cabeça para fora de meu Oceano das Mesmices, só para ver o que existia além das águas.

O que vislumbrei provocou-me surpresa, fascínio, admiração.

Dei-me por mim mesmo numa dimensão insuspeitada, porém já ocupada por outros, que já haviam ousado, muito, muito antes de mim.

Acolheram-me com alegria, afeto, aceitação e compaixão.

Senti-me então parte de um todo muito maior do que mim mesmo e isso, em instantes tão difíceis, deu sentido à minha vida.

Este trabalho constitui uma simples tentativa de uma visão mais objetiva daquilo que existe além do impreciso limite das águas em eterno movimento. 


\section{RESUMO}

Cavini-Ferreira, R. Respostas autonômicas e neuroendócrinas à recuperação de memórias traumáticas. São Paulo: Instituto de Psicologia da Universidade de São Paulo, 2005.

Diversos procedimentos são capazes de induzir a recuperação de memórias traumáticas (RecMem). Técnicas de psicoterapia têm sido usadas para reduzir a resposta emocional a estas memórias, através de processos de re-estruturação e re-significação das vivências, baseados na resiliência dos sujeitos. Durante a Rec-Mem podem ocorrer sinais clínicos de ativação autonômica que não são reações devidas a estressores externos. Pelo contrário, constituem o resultado de estímulos de natureza psíquica. Assim, é possível se questionar se eles podem funcionar como estressores puramente psicológicos e, como tais, induzir respostas autonômicas e neuroendócrinas. O objetivo deste trabalho é determinar se estas respostas ocorrem, assim como identificar suas características qualitativas e quantitativas. Seis voluntários de ambos os sexos, previamente selecionados e avaliados por testes psicológicos (SICD, Hamilton e BDI), foram submetidos a duas condições: 1. condição controle (CC), e 2. condição de recuperação (CR). Nas duas condições os sujeitos foram colocados em ambiente controlado, com coleta de material destinado a dosagens de ACTH, adrenalina, cortisol, prolactina, TSH e GH a cada 15 minutos, por 2 horas, com a primeira coleta 30 minutos antes do início dos procedimentos. Os sujeitos repousaram durante este período. Após o início dos procedimentos os sujeitos permaneceram em repouso e, na CR foram submetidos aos processos de Rec-Mem, com seguimento psicoterapêutico subseqüente. Os dados obtidos foram avaliados quanto ao perfil das curvas de tempo e resposta para cada hormônio e submetidos a testes estatísticos de comparação da secreção hormonal. Concluímos que existiram respostas autonômicas e neuroendócrinas compatíveis com estresse psicológico, onde se ressalta a variabilidade das respostas individuais obtidas.

Palavras-chave: Neuroendocrinologia; Memória; Trauma Emocional, Stress, Psicoterapia 


\begin{abstract}
Cavini-Ferreira, R. Autonomic and neuroendocrine responses to traumatic memory retireval. São Paulo: Instituto de Psicologia da Universidade de São Paulo, 2005.

Several procedures are able to induce retrieval of traumatic memories (Rec-Mem). Psychotherapy techniques have been used to reduce emotional response of these memories through re-building and re-meaning of the traumatic memories based on the subject's resilience. Clinical signs of autonomic activation may be seen during Rec-Mem, not representing reactions to external stressors. On the contrary, they are the result of psychic inputs. Therefore, it is possible to speculate that they can act as pure psychological stressors and, as such, they are able to induce autonomic and neuroendocrine responses. The aim of the present report is to determine whether or not these responses actually happen, as well as to determine their qualitative and quantitative characteristics. Six volunteers of both sexes, previously selected, and submitted to psychological testing (SCID, Hamilton and BDI), were submitted to two conditions: 1 . Control condition (CC) and 2. Retrieval condition (CR). The subjects were placed in a controlled environment with ACTH, cortisol, adrenalin, prolactin, TSH and GH blood testing at every 15 minutes, for 2 hours; the first sample was obtained 30 minutes before the beginning of the procedures. All the subjects rested during this period of time. After the beginning of the procedures the subjects remained resting and, in the CR were submitted to Rec-Mem procedures followed by psychotherapeutic support. The resulting data were analyzed by time-responses curve profiles as well as were submitted to hormonal secretion statistical evaluation in both conditions. We conclude for autonomic and neuroendocrine responses compatible with psychological stress, with remarkable variability of individual obtained responses.
\end{abstract}

Keywords: Neuroendocrinology; Memory; Emotional Trauma; Stress; Psychotherapy. 


\section{LISTA DE ABREVIATURAS}

ACTH

ADR

CORT

$\mathrm{CRH}$

CREB

$\mathrm{CC}$

CR

EMC

FSH

FSO

$\mathrm{GH}$

GHrerin

GHRH

GnRH

GR

HPA

IGF

LC

LC/NA

LH

LHRH

MMT

MR

\section{hormônio adrenocorticotrófico, corticotrofina}

adrenalina

cortisol

hormônio liberador da corticotrofina

proteina ligadora do elemento respondedor ao AMP cíclico

condição controle

condição de recuperação

estado modificado de consciência

hormônio folículo estimulante (gonadotrofina)

fobia social

hormônio somatotrófico, somatotrofina, hormônio do crescimento

peptídeo estimulador da somatotrofina

hormônio liberador da somatotrofina

hormônio liberador das gonadotrofinas

receptor de glicocorticóides (tipo II)

eixo hipotálamo hipófiso adrenal

fator insulino-símile de crescimento

locus ceruleus

sistema locus coeruelus noradrenérgico autonômico

hormônio luteinizante (gonadotrofina)

hormônio liberador do LH (gonadotrofinas)

momento mais traumático

receptor de mineralocorticóides (tipo I) 
melanotrofina, hormônio melanotrófico

PNMT

feniletanolamina-N-metil transferase

PRL

prolactina

PROTEÍNA fos produto da expressão gênica imediata e precoce

Rec-Mem

recuperação de memórias traumáticas

RNA

ácido ribonucleico

R-PRL

receptor (es) de prolactina

R-PRL-RNAm

RNA mensageiro codificador do receptor de prolactina

SRIF

somatostatina, fator de inibição da somatotrofina

TAG

transtorno de ansiedade generalizada

TEPT

transtorno do estresse pós-traumático

TRH

hormônio liberador da tireotrofina

TRV

terapia re-estruturativa vivencial

$\mathrm{TSH}$

hormônio tireotrófico, tireotrofina

$\mathrm{T} 3$

triiodotironina

$\mathrm{T} 4$

tetraiodotironina, tiroxina

V

vivência

5HT 
SUMÁRIO

\section{RESUMO}

\section{ABSTRACT}

\section{LISTA DE ABREVIATURAS}

1. INTRODUÇÃO 13

1.1. Memória 14

1.2. Hormônios e memória 19

1.3. Hormônios e estresse 25

1.3.1. Eixo HPA - Sistema CRH 25

1.3.2. Estresse e eixo hipotálamo-hipófiso-adrenal (HPA) 27

1.3.3. Estresse, adrenalina e noradrenalina 32

1.3.4. Estresse e hormônio tireoestimulante (TSH) 33

1.3.5. Estresse e prolactina 34

1.3.6. Estresse e hormônio do crescimento $(\mathrm{GH})$

1.4. Transtorno do estresse pós-traumático (TEPT) 37

1.5. Recuperação de memórias traumáticas (Rec-Mem) 39

1.6. Conclusão 42

2. OBJETIVOS $\quad 44$

2.1. Objetivos 45

3. MATERIAL E MÉTODOS 46

3.1. Sujeitos 47

3.2. Consentimento 47

3.3. Condição médica dos sujeitos 47

3.4. Ambiente 47

3.5. Experimento 48

3.6. Dosagens hormonais 49

3.7. Procedimentos e testes prévios ao experimento 50

3.8. Análise estatística dos resultados 51

4. RESULTADOS 52

4.1. Sujeito 1

4.2. Sujeito 2

4.3. Sujeito $3 \quad 72$

4.4. Sujeito $4 \quad 81$

4.5. Sujeito 5

4.6. Sujeito $6 \quad 99$ 


\section{DISCUSSÃO}

5.1. Discussão Individual

5.1.1. Sujeito 1

5.1.2. Sujeito 2

122

5.1.3. Sujeito 3

131

5.1.4. Sujeito 4

137

5.1.5. Sujeito 5

142

5.1.6. Sujeito 6

149

5.2. Discussão Geral

156

5.2.1. Eixo HPA

156

5.2.2. Adrenalina

164

5.2.3. Prolactina

168

5.2.4. TSH

172

5.2.5. GH

175

6. CONCLUSÕES

180

6.1. Conclusões

181

7. REFERÊNCIAS

182

8. ANEXOS

190

Ata do Comitê de Ética

191

Tabela VII

192

Tabela VIII

193 
Sonhar é acordar para dentro.

(Mário Quintana)

1. INTRODUÇÃO 
O objetivo deste tópico é o de traçar um panorama geral do conhecimento relacionando áreas neurais com os processos envolvidos na resposta ao estresse, assim como com o fenômeno de memória, o que leva em conta principalmente os aspectos hormonais com ela envolvidos.

\subsection{Memória}

O fenômeno da memória envolve complexas ações dentro do sistema nervoso que vão de circuitos neuronais à sua expressão molecular. A abundante literatura disponível inclui eventos sinápticos (ABE, 2001;MAREN, 2000), síntese de receptores (AMPA, GABA-A, 5HT- $1^{\text {A }}$, ação de neurotransmissores, eventos intracelulares e intranucleares tais como a ação de quinases proteicas, a fosforilação da CREB e a expressão da proteína Fos (HALL et al., 2001), assim como processos neuroquímicos relativos à ação de hormônios e neuromoduladores relacionados com aspectos emocionais, afetivos, ou com o nível de alerta, de estresse, de ansiedade ou de prazer (IZQUIERDO, 1999).

Memória é uma função que permite a mudança do comportamento por meio da experiência (XAVIER, 1996).

Assim, memória pode ser entendida como a capacidade de organizar e reconstruir as experiências e impressões passadas a serviço das necessidades, dos temores e dos interesses atuais ou antecipatórios (SCHACHTEL, 1974). Isto é, ela permite a animais e seres humanos a capacidade de adquirir, reter e recuperar informação para uso oportuno, que se manifesta por meio da possibilidade de respostas flexíveis aos estímulos ambientais. Não existisse a memória como função, tenderíamos sempre a repetir um padrão inato de resposta.

A aquisição de memória explícita envolve: 1. codificação, 2. consolidação, 3. armazenamento e 4. recuperação de informação (KANDELL, 2000) ou 1. aquisição, 2. 
formação, 3. conservação e 4. evocação de informações, sendo que os maiores reguladores da aquisição, da formação e da evocação das memórias são as emoções e os estados de ânimo (IZQUIERDO, 2002). A recuperação, ou evocação de uma memória, será tanto mais eficiente quanto mais semelhante for o contexto de sua ocorrência ao da aquisição da informação, isto é, na presença das mesmas pistas disponíveis para o indivíduo durante o aprendizado, isto é, uma memória dependente do estado (IZQUIERDO, 2004). Em princípio, quanto mais complexo for o sistema nervoso maior a probabilidade de usar, com maior diversidade, as possibilidades ambientais. De um ponto de vista seletivo, quem é capaz de aprender e fazer uso do aprendizado de uma forma tal que lhe permita atingir o sucesso reprodutivo, terá este traço transmitido às gerações seguintes. Assim, os processos de percepção e de memória estão intimamente ligados à geração de comportamentos adaptativos. As estratégias que foram adaptativas e perfeitamente funcionais no passado são assim usadas como parâmetros de avaliação da situação presente, disparando modelos de resposta fundamentados no material estocado. É por isso que o aprendizado pode produzir comportamentos inadequados. Estes podem, em certas situações, levar, particularmente o ser humano, a distúrbios psicológicos. No dizer de Kandel (Kandel, 2000, p. 1227),

“[...] nem tudo o que aprendemos é benéfico. O aprendizado também produz comportamentos disfuncionais e estes comportamentos podem, no extremo, constituir distúrbios psicológicos. O estudo do aprendizado é, portanto, central para a compreensão de distúrbios comportamentais tanto quanto sobre o comportamento normal, já que aquilo que é aprendido pode, freqüentemente, ser desaprendido. Quando a psicoterapia tem sucesso no tratamento de distúrbios comportamentais, ela freqüentemente o faz por criar um ambiente no qual o indivíduo aprende a modificar seu padrão de comportamento".

O processo de recuperação de uma memória, particularmente traumática e emocional, parece ser de natureza reconstrutiva, pois o cérebro armazena traços de informação que são posteriormente usados para a criação de memórias que nem sempre representam a realidade factual da experiência geradora. Caso contrário, reconheceríamos uma dada situação somente se ela se apresentasse de maneira idêntica outra vez. 
De fato, é comum se observar grande variabilidade de respostas individuais a uma grande variedade de eventos. Isso leva à possibilidade de que a percepção subjetiva de uma situação é, provavelmente, o principal determinante do tipo de resposta. Assim, as características consideradas como objetivas de um determinado evento não são somente as únicas que determinam as respostas, pois cada evento em si pode ter um significado pessoal e idiossincrático, perdendo, assim, suas características de objetividade (BIONDI; PICARDI, 1999; PERES et al., 2005).

É de se supor, assim, que para a construção de uma memória e a sua reconstrução subseqüente, o mesmo fenômeno ocorra: o que é dramático para um, pode ser destituído de significado para outro. Não podemos, por outro lado, esquecer-nos de que o trauma determinante da formação de uma dada memória, particularmente se for repetitivo, pode ter efeitos plásticos sobre o hipocampo, com mudanças da citoarquitetura e supressão da neurogênese, inclusive em humanos, provocando deficiência do desempenho de memórias contextuais, espaciais e declarativas (McEWEN, 1999), e não apenas por meio da subjetividade perceptual acima aludida.

Por longo tempo, os mecanismos neurais de emoção e de memória foram considerados como processos paralelos, que se davam na intimidade do sistema límbico. Hoje, isso não é mais um conceito aceitável. Tendo em conta as bases neurais da memória e da emoção, tal conceito foi substituído pela idéia de circuitos específicos que respondem por esses processos.

$\mathrm{Na}$ atualidade, é consensual que a amídala está envolvida na mediação das emoções e do estresse sobre o aprendizado e a memória, por meio das já citadas interações dentro do sistema nervoso.

O núcleo basolateral da amídala parece ser um local crítico para a integração de influências neuromoduladoras que regulam a consolidação de diversas formas de memória, com a participação noradrenérgica de fibras provenientes do núcleo basal magnocelular, 
assim como acetil-colinérgica a partir do núcleo basal (McGAUGH et al., 2002). O efeito do estado de alerta emocional sobre a consolidação da memória parece ser também mediado pela liberação de hormônios supra-renais (adrenalina e glicocorticóides), assim como de neurotransmissores que convergem para a modulação do sistema noradrenérgico. Sugere-se que esse sistema modulador de memória possa estar envolvido na formação de memórias traumáticas e do Transtorno do Estresse Pós-Traumático (TEPT) (McINTYRE et al., 2003). Além do que, o próprio córtex, particularmente os córtices entorrinal e hipocampal, por meio de projeções que recebem a partir do núcleo basolateral da amígdala, parecem estar envolvidos crucialmente nos processos de consolidação e de expressão da memória (IZQUIERDO; McGAUGH, 2002; McINTYRE et al., 2003; MEDINA, 1993). Kandel (Kandel, 2000, p. 1227) é explícito ao dizer que:

"[...] apesar da amígdala estocar componentes da memória relacionadas com a emoção, ela não estoca a informação factual. Em contraste, danos seletivos no hipocampo e em áreas associativas polimodais no córtex temporal com as quais o hipocampo se conecta - córtices perirrinal e para-hipocampal - produz claro prejuízo na memória explícita”

Assim como descreve, em princípio, o caminho percorrido pelo processamento da memória:

\begin{abstract}
“[...] o conhecimento estocado como memória explícita é inicialmente adquirido através do processamento em uma ou mais de três córtices associativos polimodais (pré-frontal, límbico e parieto-occipto-temporal) que sintetiza informação visual, auditiva e somática. Daí, a informação é levada em séries para os córtices parahipocampal e perirrinal, então para o córtex entorrinal, o giro denteado, o hipocampo, o subículo e, finalmente, de volta para o córtex entorrinal. Deste, a informação é re-enviada para os córtices parahipocampal e perirrinal e, finalmente, para as áreas associativas polimodais do neo-córtex".
\end{abstract}

Sugere que o próprio hipocampo seja uma estação temporária para a consolidação de memória de longo prazo: ele lentamente transfere informação para o sistema de armazenamento do neocórtex, o que permite que novos dados sejam estocados de uma maneira que não prejudicam a informação pré-existente. As áreas associativas parecem, assim, ser os últimos repositórios da memória explícita. Quanto maior for o número de 
associações que fizermos em relação a um elemento, melhor será codificada a imagem deste elemento e melhor nos lembraremos das suas características no futuro: a palavra designativa desse elemento associa-se com todas estas peças de informação de tal forma que apenas um único elemento da informação pode abrir todo o acesso ao seu conhecimento. Todas as vezes que uma memória traumática é recuperada por meio dessas "pistas", ela provoca modificações cognitivas e emocionais, que podem estar associadas a fenômenos intracelulares e nucleares (HALL et al., 2001).

Observando imprecisões no processo de se lembrar de fatos passados, Loftus demonstrou o fenômeno de falsas memórias (LOFTUS, 1996; LOFTUS; POLAGE, 1999), dificilmente distinguíveis das memórias verdadeiras (DELMONTE, 2000), pois ambas podem conter elementos igualmente convincentes, o que sugere que as semelhanças entre memórias verdadeiras e falsas memórias são mais profundas do que se supõe (GONSALVES; PALLER, 2002; IZQUIERDO, 2004; LEICHTMAN et al., 2000).

As respostas aos traumas parecem ser guiadas por crenças emocionais a despeito de sua precisão, e podem provocar respostas neurofisiológicas relativas a memórias de fatos impossíveis de terem acontecido na realidade, tal como se dá no Transtorno do Estresse PósTraumático (TEPT) (BECKMAN, 2003). Peres e colaboradores (PERES et al., 2004), ponderam sobre o fato:

\footnotetext{
"[...] a pesquisa sobre os traumas e a psicoterapia encara um assunto crucial. Apesar de uma memória emocional nem sempre prover uma figura fática completa da experiência passada, o conteúdo emocional, configurado como uma memória, é absolutamente genuíno em sua representação de referências internas e suas dinâmicas psicológicas correspondentes. O processo humano natural de misturar e falsificar memórias não pode ser negado ou evitado pelos psicoterapeutas. Pelo contrário: ele precisa ser usado efetivamente para promover a saúde psicológica".
}

A recuperação de memórias traumáticas freqüentemente traz à tona material referido como memórias que, por suas natureza e contexto, são claramente impossíveis de terem acontecido durante a vida do indivíduo. No entanto, seu conteúdo emocional é genuíno, pois 
uma emoção enquanto tal jamais é falsa. Ela é independente do tipo de enredo, da natureza do conteúdo e do contexto temporal a ela incorporados. No escopo deste trabalho, tais vivências serão encaradas sob um puro ponto de vista fenomenológico.

\subsection{Hormônios e Memória}

A participação hormonal nos processos relativos à memória envolve a idéia de ação hormonal sobre o sistema nervoso.

Abundante evidência científica suporta essa hipótese. Experimentos clássicos eram realizados por meio dos efeitos da ablação glandular (cirúrgica ou química), sobre o aprendizado e a memória, assim como os subseqüentes efeitos da reposição hormonal. Trabalhos mais antigos, já chamavam a atenção para a importância temporal dos procedimentos, por meio de administração do hormônio depois da ablação da glândula e do treinamento, mas antes da recuperação do processo aprendido, assim como influência dos hormônios sobre o aprendizado, sobre a consolidação e a recuperação da memória (RIGTER et al., 1974; RIGTER, 1982). Posteriormente, demonstrou-se a ação de neuro-hormônios, e seus análogos, sobre o aprendizado e a memória, por meio de estudos sobre envelhecimento e sobre a deficiência de memória operacional em ratas, relacionando-os com o envelhecimento de seu sistema reprodutivo (ALLIOT; GIRDY, 1991; ALLIOT et al., 1993).

As relações do hormônio liberador da corticotrofina (CRH), molécula considerada como integradora das respostas neuroendócrinas e autonômicas ao estresse (FISHER, 1989) com memória, podem ser evidenciadas pela sua ação sobre o locus coeruleus de ratos, mediada por noradrenalina, na retenção da esquiva passiva, melhorando o desempenho de retenção de memória, que se dá concomitantemente com redução de noradrenalina no 
hipocampo e na amígdala, sugerindo a participação do sistema nor-adrenérgico dorsal nos processos de consolidação da memória (CHEN et al., 1992).

A ação dos hormônios hipofisários sobre o aprendizado, sobre a consolidação e a recuperação da memória passa, necessariamente, pelo modelo baseado na ação dos neurohormônios sobre a hipófise, induzindo a secreção ou inibição de seus hormônios. Este deve ser visto como um modelo simplificado, já que parecem existir processos muito mais complexos. Estes levam em conta não só a participação das células da glia na regulação neuroendócrina (GARCIA-SEGURA et al., 1996), como também as ações intra-hipofisárias de suas próprias secreções, o que se dá por meio de mecanismos autócrinos, parácrinos e endócrinos. Essa interação ocorre por meio de neuro-hormônios, de hormônios hipofisários e de diversas outras substâncias, tais como galanina, angiotensina I e II, ativina, interleucina-6, folistatina, neuropeptídeo $\mathrm{Y}$, neurotensina, endotelina 3, acetil-colina, peptídeo intestinal vasoativo, substância P e $\alpha$-MSH, entre outros (SCHWARTZ; CHERNY, 1992). Assim, a secreção de cada hormônio hipofisário reflete não só a ação de um neurormônio específico sobre células específicas em processos específicos, como também o resultado da interação recíproca das diferentes células hipofisárias entre si por meio de diversas substâncias.

Experimentos mais antigos já demonstravam o prejuízo provocado pela hipofisectomia sobre o desempenho do aprendizado na esquiva ativa em roedores, efeito que seria independente da ação da adrenocorticotrofina (ACTH) e de suas frações (ACTH 4-10 e ACTH 1-10) sobre a córtex adrenal, sugerindo que também não se devia à melhora da motilidade prejudicada pela hipofisectomia, mas sim por ação do ACTH sobre uma função de suporte, e não sobre o aprendizado propriamente dito; a fração ACTH 4-10 estaria relacionada com a melhora transiente da atenção, ou da motivação. Apesar de muitos dos efeitos do ACTH e peptídeos ACTH-símiles se darem pela modulação de alguma função de suporte do 
aprendizado e de recuperação da memória, é possível que algumas substâncias possam agir sobre o próprio mecanismo de formação de memória (MCGAUGH; GOLD, 1989).

Trabalhos realizados em roedores sugerem que o efeito da administração do hormônio do crescimento $(\mathrm{GH})$ sobre a memória de longo prazo parece depender do instante de sua administração (HODDES, 1979). Esses autores demonstraram retenção máxima com administração do GH aos 90 minutos antes do aprendizado e 30 minutos após ele, sendo que a mínima retenção se situou em torno dos 5 minutos antes do aprendizado original, isto é, uma tendência quadrática com curva de resposta em forma de "U". Outros trabalhos, utilizando tanto o GH quanto seu neuro-hormônio liberador (GHRH), mostram que ambos são capazes de modular tanto a memória de longo prazo quanto sua extinção, sendo a resposta dependente da idade do animal: GH e GHRH facilitam a memória de longo prazo em animais jovens, mas não em animais idosos. A única dissociação de efeitos se relaciona com o fato de que, enquanto o GH retarda a extinção tanto em jovens quanto em idosos, o GHRH só retarda a extinção da memória em ratos idosos (SCHNEIDER-RIVAS et al., 1995).

Estudos dos efeitos do GH sobre memória em humanos são contraditórios, talvez devido ao fato de terem sido realizados principalmente em pacientes que apresentavam deficiência de GH iniciada em diversos instantes da vida. Uns indicam a importância do hormônio do crescimento $(\mathrm{GH})$ sobre uma diversidade de capacidades cognitivas, incluindo memória de curto e longo prazo (DEIJEN et al., 1998), o que aumenta, em doses suprafisiológicas, o desempenho de recuperação de memórias explícitas; outros, não comprovam tal efeito (BAUM et al., 1998), sendo que o fator envolvido na ação do GH sobre a memória seria a idade do desenvolvimento da deficiência de GH. Com efeito, adultos com deficiência de GH desenvolvida na infância mostram-se sensíveis às ações do GH, enquanto que adultos que desenvolveram a deficiência de GH enquanto adultos, não mostram tais resultados. Mais recentemente surgiram evidências da ação do GHRH sobre a melhoria do 
desempenho de memória em humanos, sugerindo que o $\mathrm{GH}$ e o fator insulínico de crescimento (IGF-1) apresentam importantes efeitos sobre funções cerebrais, e que o declínio do GH e do IGF-1 com a idade contribui para as dificuldades relativas à memória observadas à medida que se envelhece. Essas alterações são reversíveis pela administração crônica do GHRH (THORNTON et al., 2000).

Ratos hiperprolactinêmicos apresentam melhor aquisição de respostas de esquiva ativa, sem alterações observadas na sua extinção, ou no paradigma de esquiva inibitória (DRAGO et al., 1983), o que sugere a existência de ação da prolactina (PRL) sobre o aprendizado. Neuro-hormônios também apresentam efeitos sobre a memória. Tanto o hormônio liberador de gonadotrofinas (GnRH, LHRH), quanto o hormônio liberador da tireotrofina (TRH) (NASELLO, 1980), são capazes de influenciar a esquiva condicionada em roedores. O LHRH em altas doses parece estar relacionado com a redução de sua aquisição, envolvendo interações com catecolaminas cerebrais (NASELLO et al., 1983) e aparentemente antagonizando a melhora da aquisição e retenção induzidos pela testosterona (MORA et al., 1983). O TRH, por sua vez, possivelmente através de mecanismos envolvendo catecolaminas cerebrais, melhora a esquiva condicionada em roedores (MORA, et al.,1980).

É consensual que os hormônios tireoidianos têm um papel crítico no desenvolvimento cerebral de mamíferos, existindo abundante literatura a respeito. A disponibilidade desses hormônios é essencial não só para o adequado desenvolvimento nos níveis funcional celular e molecular (ANDERSON, 2001) e maturação cerebral, controlando diversos genes no sistema nervoso central, como também para a diferenciação das células lactotróficas e somatotróficas hipofisárias (KÖHRLE, 2000), para um bom desempenho da cognição, o que envolve os processos de recuperação de memória, de concentração, de estado de alerta, de pensamento e de motivação (BURMEISTER et al., 2001). A administração de hormônios de tireóide parece recuperar o declínio cognitivo observado com a senescência, mas não do hipotireoidismo 
primário (MENNEMEIER et al., 1993). O hormônio tireotrófico (TSH) encontra-se positivamente relacionado com a performance da memória episódica, em termos de seus efeitos potenciais sobre sua codificação e a consolidação (WAHLIN et al., 1998). São tão importantes as ações dos hormônios tireoidianos sobre a memória que, mesmo na disfunção mínima da tireóide ("hipotireoidismo pré-clínico” ou "hipotireoidismo sub-clínico”), observam-se funções cognitivas prejudicadas, assim como disfunção da contratilidade miocárdica, o que justifica o tratamento precoce (MONZANI et al., 1991), assim como o uso de tais hormônios em pacientes psiquiátricos portadores de doença bi-polar (TREMONT; STERN, 1997) e em deprimidos (HENLEY; KOEHNLE, 1997), possivelmente por meio da interação dos hormônios tireoidianos com receptores $\beta$-adrenérgicos pós-sinápticos (WHYBROW; PRANGE, 1981) e com as possibilidades de compreensão dos mecanismos moleculares envolvidos na ação dos hormônios da tireóide sobre a base neural e a sua influência sobre sistemas de neurotransmissão que regulam o temperamento e o comportamento, tais como a serotonina e a noradrenalina (BAUER; WHYBROW, 2001). Há importante co-morbidade entre disfunções tireoidianas e doenças psiquiátricas (CAVINIFERREIRA, 1999; CAVINI-FERREIRA; SINGAL, 1994).

A despeito da possível interferência de sintomas de menopausa sobre o desempenho da memória, parecem ocorrer variações de certos aspectos de memória em mulheres com menopausa induzida cirurgicamente, coincidente com as alterações dos níveis plasmáticos de estrona e estradiol (PHILIPS; SHERWIN, 1992a), apesar de que as dificuldades de memória observadas em mulheres menopausadas podem também ser devidas à depressão, o que poderia ser responsável pelo declínio cognitivo pós-operatório. Durante o ciclo menstrual, observaram-se flutuações no desempenho de memória visual, associadas às flutuações de esteróides sexuais, sendo que os níveis de estradiol se correlacionam positivamente, e os de testosterona negativamente, com a memória verbal (PHILLIPS; SHERWIN, 1992b). Por 
outro lado, parece que os estrógenos apresentam uma ação ativadora geral sobre as funções cognitivas, em vez de efeitos específicos sobre elas (HOGERVORST et al., 1999, HOGERVORST et al., 2002, HOGERVORST et al., 2004).

Esteróides, tais como os glicocorticóides e hormônios sexuais, também se relacionam com o aprendizado e com a memória inclusive em humanos. Mesmo quando não se sabe com precisão o mecanismo da ação hormonal nesses processos, é o cérebro o alvo final de sua ação. Evidências indicam as células da glia como alvos da ação de esteróides e hormônios tireoidianos, com seus correlatos funcionais (GARCIA SEGURA et al., 1996). Hormônios gonadais e adrenais apresentam efeitos sobre o sistema nervoso, os quais são capazes de induzir alterações morfológicas da formação hipocampal. Observam-se mudanças na citoarquitetura e aumento do tamanho celular e do número de células CA3 e CA1 após a administração neonatal de hormônios tireoidianos, o que reforça a idéia de sua ação plástica, assim como a dependência da sobrevivência de células granulosas do giro denteado aos glicocorticóides. A ooforectomia bilateral em ratas é seguida por um significativo decréscimo das espinhas dendríticas das células $\mathrm{CA}_{1}$, efeito prevenível pela administração de estradiol. Portanto as flutuações dos esteróides ao longo do estro, quiçá no ciclo menstrual em humanos, do estresse, dos ritmos circadianos e do envelhecimento, devem ser considerados nos processos relativos ao aprendizado e à memória (GOULD et al., 1991; GOULD et al., 1990a, $1990 \mathrm{~b}$ e 1990c).

O efeito de hormônios do estresse (tais como adrenalina, noradrenalina e cortisol, entre outros), sobre a formação de memórias traumáticas tem sido estudado em pacientes internados em unidades de terapia intensiva (SCHELLING, 2002). Sabe-se que memórias traumáticas são formadas numa grande proporção desses pacientes e podem fazer parte do processo de desenvolvimento do Transtorno do Estresse Pós Traumático (TEPT). Em tais pacientes, rigidamente monitorizados, a administração de adrenalina, noradrenalina e cortisol 
em grandes doses por razões médicas, provocam melhor consolidação das memórias traumáticas relativas à hospitalização, mas com significativa redução de sintomas tipo TEPT após sua recuperação e alta hospitalar. Esse efeito pode ser teoricamente explicado pelo fato de que níveis elevados de cortisol plasmático não só resultam em melhor consolidação das memórias emocionais como causam um impedimento temporário na recuperação de tais memórias, o que parece ser independente dos efeitos do cortisol sobre a formação de memória, que age assim de maneira a proteger o desenvolvimento de TEPT. É possível que esse efeito duplo do cortisol, melhorando a consolidação das memórias emocionais, mas dificultando sua recuperação, seja devido à sua ação dependente da ativação noradrenérgica do complexo basolateral da amídala e suas interações com outras regiões cerebrais (ROOZENDAAL, 2002).

Parece que os hormônios do estresse, em particular a adrenalina, modulam os processos de consolidação de memória para experiências que induzem sua liberação (CAHILL; ALKIRE, 2003). O excesso de catecolaminas secretadas durante o trauma, não refreado pelos corticóides, tal como se observa no TEPT, levaria à consolidação excessiva das memórias traumáticas, pois os corticóides parecem modular a consolidação da memória induzida por catecolaminas (GRAEFF, 2003).

\subsection{Hormônios e Estresse}

\subsubsection{Eixo Hipotálamo-Hipófiso-Adrenal (HPA) - Sistema CRH}

Foi no início do século XX que se começou a estudar, objetivamente, as reações fisiológicas de um animal submetido a uma ameaça, por meio dos trabalhos fundamentais de Walter Cannon e Hans Selye. Em 1981, o grupo de Valle (VALLE et al., 1981) logrou identificar um peptídeo de 41 aminoácidos com potente ação estimuladora sobre a secreção hipofisária do ACTH. Com isso, finalmente se esclareceu a via através da qual o sistema 
nervoso era capaz de induzir a secreção do cortisol, em suporte à visão firmada por Harris, em 1948 (HARRIS, 1948) e dando sentido à proposição de Selye, feita cerca de meio século antes. Com a síntese em laboratório do $\mathrm{CRH}$, as pesquisas ganharam novo impulso. Hoje, admite-se a existência de um verdadeiro "Sistema CRH" no sistema nervoso central, com funções que ultrapassam sua mera relação com o $\mathrm{ACTH}$, tais como o comportamento e a regulação autonômica (PETRUZ; MARCHENTHALER, 1992). Os neurônios desse sistema se dividem em hipotalâmicos, provenientes do núcleo paraventricular em associação com o sistema porta-hipofisário, e extra-hipotalâmicos, cujos corpos celulares estão localizados e/ou inervam estruturas límbicas envolvidas com a ansiedade, tais como amídalas, locus ceruleus e substância cinzenta periaquedutal. Além desses, há pequenos neurônios bipolares da terceira camada do córtex frontal, relacionados com a resposta comportamental ao estresse. Há evidências que indicam o disparo temporalmente diferenciado destes neurônios que regulam uma resposta escalonada ao estresse: primeiro, o comportamento, segundo, a ativação autonômica e, finalmente, a ativação do eixo HPA (SCHULKIN et al., 1998; WOLF, 2003). Esse escalonamento temporal pode ser rompido, como ocorre no TEPT (GRAEFF, 2003). O CRH é considerado como molécula integradora das respostas autonômicas, endócrinas e, quiçá, imunológicas ao estresse (FISHER, 1989). Recentemente, têm surgido evidências que indicam a participação da adrenomedulina, peptídeo classicamente descrito como um potente agente vasodilatador, natriurético e diurético, como elemento que organiza a resposta do sistema nervoso central ao estresse, o que envolve não só a resposta do eixo HPA como também a regulação da secreção do $\mathrm{GH}$ e prolactina. Esse efeito, inibido pelo pré-tratamento de antagonistas do $\mathrm{CRH}$, sugere que a adrenomedulina age por meio do CRH em sua ação central relativa ao estresse (HAMID; BAXTER, 2005; TAYLOR; SAMSOM, 2004). 


\subsubsection{Estresse e eixo HPA (Hipotálamo-Pituitárico-Adrenal)}

O eixo HPA representa uma alça funcional onde se processa a ativação de uma reação em cascata: CRH (hipotálamo) > ACTH (hipófise ou pituitária) > cortisol (suprarenal ou adrenal). Portanto, a descrição dos eventos envolvendo estes três hormônios (e os citados sítios do sistema endócrino) será feita conjuntamente sob a designação de "Eixo HPA", tal como é referido na abundante literatura disponível.

Historicamente, o conceito de estresse tem sido associado a modificações do sistema endócrino observadas diante de uma situação adversa. De um ponto de vista fisiológico, o estresse apresenta certas características importantes: primeiro, uma diversidade de estímulos físicos e químicos é capaz de provocar a mesma resposta do eixo HPA, o que sugere um modelo filogenético de resposta. Nesse particular, o aspecto temporal do estímulo é de fundamental importância: estímulos agudos provocam resposta do eixo HPA, o mesmo não ocorrendo com estímulos crônicos (GANN, 1969).

Assim, o estresse pode ser considerado como uma reação geral de alarme de sistemas homeostáticos. No dizer de Ursin e Eirksen (URSIN; ERIKSEN, 2003):

A resposta ao estresse é uma reação de alarme num sistema homeostático, produzindo ativação neurofisiológica geral e inespecífica de um nível de alerta para outro, mais elevado.

Mason (MANSON, 1975) sugere que a reação fisiológica em parece se constituir no estímulo inicial para a cascata de fenômenos neuroendócrinos que se observa subseqüentemente à situação estressante. Devem existir, assim, diversos processos situados no sistema nervoso central que determinam se o eixo HPA será ou não ativado. Tsigos e Chrousos(2002) (TSIGOS; CHROUSOS, 2002) sugerem que o principal componente dos sistemas relacionados com o estresse é constituído pelo CRH e pelo sistema locus ceruleusnoradrenérgico-autonômico (LC/NA) e seus efetores periféricos: o eixo hipotálamo-hipófisoadrenal (HPA) e as alças do sistema nervoso autonômico. O CRH e o LC/NA são capazes de 
estimular o alerta e a atenção, assim como o sistema noradrenérgico dorsal. Durante o estresse, o CRH inibe a secreção do GnRH e, via somatostatina, inibe a secreção do GH, do TRH e do TSH, sistemas que recebem e dependem de estímulo catecolaminérgico. Os glicocorticóides, produto final do eixo HPA, simultaneamente inibem o CRH, o LC/NA e os sistemas beta-endorfínicos, e estimulam o sistema noradrenérgico dorsal e o núcleo central da amígdala. Em que pese haver evidências de que o GH é liberado pelo estresse (CONTEDEVOIS et al., 1993), os glicocorticóides inibem diretamente o hormônio luteotrófico (LH) e o hormônio folículo estimulante (FSH), assim como a secreção de GH e TSH, além de suprimir a ação da 5'deiodinase, o que reduz a conversão de tiroxina (T4) em triiodotironina (T3). O CRH central, via glicocorticóides e catecolaminas inibe a reação inflamatória, enquanto que o mesmo $\mathrm{CRH}$, secretado por nervos periféricos, a estimula. Isso tudo sublinha o papel importantíssimo do $\mathrm{CRH}$ como molécula chave integradora das funções endócrinas, autonômicas e imunológicas.

Evidências indicam que a percepção subjetiva da situação é, provavelmente, o principal agente determinador das respostas psicoendócrinas ao estresse. De fato, existe marcante variação da resposta individual a uma variedade de estressores. Assim, parece que cada dado estressor tem um significado estritamente pessoal, o que significa que o estressor pode perder sua característica “objetiva”, o que se superpõe à rígida dicotomia entre processos físicos e biológicos, indicando ser correta uma visão sistêmica do processo (BIONDI; PICARDI, 1999).

O enfoque psicobiológico para a compreensão da participação dos fatores fisiológicos na regulação da resposta do sistema HPA não pode escapar de uma referência cognitiva, pano de fundo para a descrição dos processos pelos quais o estado de excitação, ou de alerta, funciona; isto é, são considerados elementos excitadores: a novidade (elementos do estímulo), a incerteza (expectativa evocada pelo estímulo) e o conflito. 
Um dos mais poderosos estímulos para a estimulação das glândulas supra-renais é a novidade. Tal fato tem sido demonstrado tanto em animais quanto em humanos, e pode ser medido por meio do aumento da produção de cortisol.

Uma importante característica do processo cognitivo que resulta na ativação do eixo HPA é a capacidade de discriminação entre estímulos familiares e não familiares. De um ponto de vista quantitativo, se a novidade variar ao longo de um continuum com progressivos incrementos nos elementos do estímulo, haverá resposta gradual do córtex suprarenal, de acordo com o grau da discrepância com o ambiente ao qual o organismo está habituado. Em outras palavras, mínimas mudanças podem resultar em moderadas elevações da atividade do eixo HPA, mas menor do que as observadas quando o estímulo é totalmente novo, demonstrando claramente a capacidade que o sistema nervoso central tem de regular o efluxo hormonal das glândulas adrenais.

A incerteza faz parte de toda novidade, dado o reduzido nível de informação disponível para a predição do que vai ocorrer em seguida. A incerteza, assim, pode ser evocada pela insuficiente informação sobre a natureza dos eventos evocados, além de constituir, logicamente, num elemento resultante da apresentação de uma situação nova. Essa situação pode variar ao longo de uma gradação que vai desde eventos certos e altamente previsíveis até eventos altamente incertos e altamente imprevisíveis. Assim, teoricamente, se é dado ao organismo informação sobre a ocorrência do estímulo, é natural que se espere redução da resposta do eixo HPA. Por outro lado, em situações com absoluta ausência de previsibilidade, ocorrem grandes aumentos dessa resposta. Assim, animais submetidos a estímulos imprevisíveis apresentam níveis de ativação do eixo HPA muito maior do que a observada em animais submetidos a estímulos previsíveis, assim como pior desempenho diante de outros estímulos. Subseqüentemente, esses animais apresentam maior nível de ativação do eixo HPA quando expostos à novidade; em outras palavras, um organismo 
exposto a estímulos incontroláveis e imprevisíveis (situação de desamparo) mostra não somente maior atividade do eixo HPA como também conseqüências em longo prazo. A frustração, entendida como a falência de um animal em preencher expectativas desenvolvidas durante experiências prévias, pode ser considerada também como incerteza, e isso também provoca ativação do eixo HPA. Esses fatos são subsídios para a hipótese de que uma das condições primárias para a ativação do eixo HPA é a modificação das expectativas relacionadas com comportamentos bem estabelecidos.

A atividade do eixo HPA também pode ser inibida por estímulos psicológicos. Isto é, se a ausência de reforço leva à incerteza com conseqüente ativação do eixo HPA, a presença de estímulos previsíveis e de eventos de reforço pode levar à redução da ativação prévia do eixo HPA, o que reduz a atividade das glândulas supra-renais, indicando a existência de existam mecanismos destinados a manter a atividade supra-renal dentro de limites seguros.

Esses mecanismos podem ser fisiológicos e psicológicos.

Fisiologicamente, observa-se a regulação do eixo HPA por retroalimentação exercida pelo cortisol sobre áreas cerebrais específicas, tais como hipófise, hipotálamo e hipocampo, assim como com a retroalimentação positiva, tais como amígdala, córtex pré-frontal e tronco cerebral, em especial o locus ceruleus (LC). Sua ação se dá por meio de receptores específicos intra-celulares ou por via interativa com diferentes receptores de neurotransmissores de superfície celular (DE KLOET et al., 1998). A maioria dos efeitos do cortisol no sistema nervoso central se dá por meio de sua interação com receptores intracelulares do tipo I (MRreceptor de mineralocorticóides) e tipo II (GR-receptor de glicocorticóides), que diferem por suas afinidades específicas relativas ao cortisol: os do tipo II apresentam baixa afinidade, enquanto que os do tipo I, alta afinidade, sendo ocupado mesmo em níveis basais de cortisol. É bastante conhecida sua relação com os processos de consolidação de memória, inclusive em 
humanos, em que o cortisol parece aumentar a consolidação da memória emocional (BUCHANAN; LOVALLO, 2001).

Por outro lado, mecanismos reguladores da atividade do eixo HPA também existem no nível psicológico, envolvendo controle, retroalimentação e fatores sociais.

O controle é entendido como a capacidade de tornar ativas as respostas durante a presença de um estímulo aversivo. As respostas são usualmente eficientes para o animal evitar ou escapar do estímulo, mas também pode proporcionar uma oportunidade de mudança de um conjunto de estímulos para outro, em vez de simplesmente escapar do estímulo aversivo, o que reduz a resposta fisiológica do organismo, fato observado em primatas não humanos (HANSON et al., 1976) e em controladores de tráfego aéreo (ROSE et al., 1982).

A retroalimentação é entendida como o processo decorrente do estímulo e da informação que ocorre após a resposta comportamental, sinalizando se o organismo apresentou ou não uma resposta correta ao estímulo. Humanos em treinamento de páraquedismo mostram que a retroalimentação representada pela informação de que nada aconteceu de mau após o primeiro salto, potencialmente ameaçador, reduz significativamente os níveis plasmáticos de cortisol no segundo salto (URSIN et al., 1978).

Fatores sociais e a continuidade de relações interpessoais parecem ser elementos determinantes sobre a forma de o indivíduo administrar períodos de crises. Por exemplo, as complicações durante a gestação ocorrem em maior incidência em mulheres que experimentaram situações estressantes antes e durante a gestação, e que apresentavam baixo suporte social (NICKSOLLS et al., 1972). Outros estudos têm enfatizado a importância do suporte social na evolução do próprio câncer assim como no prognóstico de diversos processos (HUCKLEBRIDGE, 2001). 


\subsubsection{Estresse, Adrenalina e Noradrenalina}

Estressores exclusivamente psicológicos representam a origem mais importante da atividade do sistema nervoso autônomo. A participação da medula supra-renal é componente fundamental dessa resposta, capaz de promover grandes incrementos da secreção de adrenalina. Quando estes níveis plasmáticos atingem o cérebro, particularmente o hipotálamo, o resultado será uma ação facilitadora da tomada de decisão e de sua execução.

Recentes evidências indicam na íntima ligação entre a ativação do eixo HPA e a síntese de adrenalina pela medula suprarenal, mesmo levando em consideração o fato de que o córtex e a medula suprarenais possuem origens embriológicas, propriedades químicas e mecanismos de controle de sua atividade bastante diferentes. Evidências indicam a existência de uma circulação tipo porta córtico-medular, que provê para a camada medular, a partir da camada cortical, altas concentrações de glicocorticóide que são necessários para a estimulação de feniletanolamina-N-metil transferase (PNMT), enzima que controla a síntese de adrenalina a partir da noradrenalina (WURTMAN, 2002). Assim, a ativação do eixo HPA pode provocar, secundariamente, aumento da secreção de adrenalina pela medula suprarenal.

Neurônios noradrenérgicos localizados no LC inervam áreas chave do cérebro e, portanto, são importantes para os fenômenos que determinam a formação e a consolidação da memória. O LC parece ter ação principalmente inibitória sobre os alvos de sua inervação, parecendo ser a única fonte de noradrenalina para o hipocampo e o neocórtex, e recebe fortes conexões aferentes do núcleo supraquiasmático, o que sugere sua relação com o mecanismo de regulação do ciclo vigília-sono. Um único neurônio do LC pode projetar para ambos os hemisférios, para o hipocampo, para o tálamo e para o córtex, assim como para a medula espinal (FOOTE et al., 1983), o que suporta a idéia de que variações dos estímulos provenientes do LC podem influenciar simultaneamente diversas áreas, coordenando, assim, a atividade de diversos sistemas. O LC é alvo do próprio CRH (Sistema LC/NA - Locus 
ceruleus-noadrenérgico-autonômico). O CRH e o LC/NA estimulam o alerta e a atenção, e sua ação parece ser mediada pelo sistema noradrenérgico dorsal, envolvendo a hipótese de que o LC, como substrato anatômico da ansiedade, age por meio da ação ansiogênica do CRH (CHEN et al., 1992).

Nove subtipos de receptores noradrenérgicos parecem estar largamente distribuídos pelo cérebro e podem ser ativados pela noradrenalina. A seletividade de sua ação parece ser dada pela localização espacial dos receptores, por sua densidade relativa, pelas diferentes afinidades dos diferentes sub-tipos e pela seletividade temporal com que são ativados (GIBBS; SUMMERS, 2002).

\subsubsection{Estresse e TSH}

A secreção do TSH é rigidamente controlada por retroalimentação negativa exercido pelos hormônios tireoidianos. A secreção do TSH obedece a um ritmo circadiano, além de apresentar pequenos picos de secreção a cada 80 a 180 minutos, provavelmente devidos a descargas hipotalâmicas de TRH.

As alterações da secreção do TSH observadas no estresse têm sido debitadas ao metabolismo periférico do T4, como por exemplo, a elevação observada de T3 e T4 após o estresse cirúrgico (CHAN et al., 1978), mediante o rápido deslocamento de suas proteínas transportadoras, ou devido à ação de aminas biogênicas (LANGER et al., 1983).

Outros estudos sugerem inibição da atividade do eixo hipófiso-tireoidiano durante o estresse controlado. O estresse crônico também é capaz de induzir mudanças da secreção do TSH e do GH, possivelmente devido à liberação dos seus hormônios reguladores hipotalâmicos (ARMARIO, 1984; ARMARIO, 1987).

Em humanos submetidos a estresse agudo durante a prática do paraquedismo também se observou elevação do TSH, sendo que esta resposta não foi afetada pela experiência prévia do indivíduo, assim como não foram demonstradas associações entre as variáveis endócrinas e 
a performance em testes de ansiedade (SCHEDLOWSKI et al., 1992). A elevação de TSH plasmático em humanos submetidos ao estresse de exames acadêmicos sugere existir diferença sexual da resposta do sistema hipófiso-tireoidiano ao estresse psicológico (JOHANSSON et al., 1987).

\subsubsection{Estresse e Prolactina (PRL)}

A secreção de PRL é regulada por mecanismos de retroalimentação e influências neurais a partir do hipotálamo, apresentando ritmo circadiano aparentemente controlado por circuitos específicos. O estresse físico, a amamentação, a cópula, ciclo do sono e estresse emocional também influenciam sua secreção.É de conhecimento notório que a secreção da PRL é dramaticamente afetada por inúmeros estressores, tais como o éter, a imobilização forçada, o estresse térmico, a hemorragia, o conflito social e, mesmo em humanos durante conflitos acadêmicos. Estressores psicológicos puros podem não constituir estímulo freqüente para a secreção de PRL, tal como ocorre com o GH, mas a secreção de PRL como resposta ao estresse emocional parece relacionar-se com o tipo específico de emoção experimentada. Com efeito, raiva e humilhação, mas não outros estados emocionais, podem provocar elevação da secreção de PRL (SOBRINHO, 2003).

A resposta da PRL ao estresse, assim, parece diferir de acordo com a natureza do estresse.

Sabe-se que a hipoglicemia, o exercício físico e os procedimentos cirúrgicos são potentes estimuladores da liberação de PRL e GH, sendo que a PRL parece ser mais sensível que o $\mathrm{GH}$ ao estímulo físico, enquanto que este, e a hipoglicemia, estimulam mais diferencialmente a secreção do GH. Ambos, durante a hipoglicemia, somente são secretados em estados de neuroglicopenia sintomática.

A participação da PRL nos mecanismos de estimulação do córtex suprarenal, particularmente sobre a zona fasciculada em ratos hiperprolactinêmicos, tanto em adultos 
quanto em jovens, foi recentemente descrita, chamando a atenção sobre as complexas interações hormonais que se dão durante o estresse (SILVA et al, 2004).

É discutível a explicação teleológica para a elevação aguda da PRL em resposta ao estresse em humanos (DELITALA et al., 1987), não havendo uma explicação unitária para os mecanismos das respostas.

Historicamente conhecido como o hormônio hipofisário da lactação, têm lhe sidas atribuídas centenas de ações isoladas, que podem ser relacionadas com a distribuição ubíqua de seus receptores. Especula-se sobre sua participação na progressão de alguns tumores, tais como o carcinoma da próstata e das mamas, o que abre novas linhas de pesquisa para a compreensão de sua intrincada fisiologia (GOFFIN et al., 2002). Tem sido atribuída à PRL a participação em processos de auto-imunidade e doenças auto-imunes como o lupus eritematoso sistêmico (VERA-LASTRA et al., 2002). No entanto, sua importância é insuperável nos processos relativos à lactação e à reprodução, o que sugere que a maioria de suas outras ações descritas em outros tecidos alvos é relativa a processos não estritamente dependentes da PRL, mas por ela modulados.

Parece, portanto, que a PRL é um hormônio que assegura a sobrevivência da espécie por meio de seu papel na reprodução, e a sobrevivência do indivíduo por meio de seu papel na homeostasia. Um verdadeiro sistema prolactínico cerebral parece estar envolvido com a resposta adaptativa ao estresse da lactação. Com efeito, parece que este sistema estaria envolvido, por meio de ação ansiolítica e inibitória do eixo HPA e da oxitocina, num mecanismo de atenuação das respostas neuroendócrinas e comportamentais ao estresse que têm sido descritas durante a gestação e a lactação (TORNER; NEUMANN, 2002), o que reforça a idéia da PRL ser um forte candidato para regulação das respostas emocionais e neuroencócrinas ao estresse. Fatores sociais também influenciam na resposta da PRL ao estresse: a presença de conespecíficos durante a exposição à situação estressante provoca 
menor resposta de secreção de PRL do que a exposição isolada. O contato físico com conespecíficos reduz ainda mais o estresse medido pela secreção de PRL (WILSON, 2001).

Imunoreatividade para PRL tem sido detectada em terminais axônicos hipotalâmicos (FUXE et al., 1977), no córtex cerebral, no hipocampo, nas amígdalas, no septum (DEVITTO,1988), no caudatum-putamen (EMANUELE et al., 1987; HARLAN et al., 1989), no tronco cerebral e na medula espinal (DEVITO, 1988; HARLAN et al., 1989; SIAUD et al., 1989), no plexo coróide e nos órgãos circunventriculares (THOMPSON, 1982).

Receptores de PRL (R-PRL) assim como o seu RNA codificador (R-PRL-RNAm) são igualmente encontrados em diversas áreas do sistema nervoso, apresentando homologia de cerca de $30 \%$ com os receptores de GH. São encontrados no plexo coróide, no núcleo intersticial da stria terminalis, amídalas, na substância cinzenta, no tálamo, no hipotálamo, no córtex cerebral e no bulbo olfatório (FREEMAK et al., 1995; FREEMARK et al., 1996). Fora do sistema nervoso, diversos tecidos expressam R-PRL e R-PRL- RNAm: hipófise, coração, pulmão, timo, baço, fígado, pâncreas, adrenais, útero, musculatura esquelética e pele (BOYLE-FEYOT et al., 1998; NAGANO; KELLY, 1994).

\subsubsection{Estresse e Hormônio do Crescimento (GH)}

A secreção do GH pela adenohipófise é regulada tanto pelo hipotálamo quanto por mediadores das ações do GH. Os principais fatores reguladores incluem o hormônio de liberação do GH (GHRH), a somatostatina (SRIF), o peptídeo liberador do GH (GHrerin) e o IGF-I (insulin-like growth factor). Os principais mecanismos reguladores da secreção do GH são representados pelo ritmo neural endógeno (ritmo circadiano), o sono, o estresse, o exercício físico e os sinais metabólicos e nutricionais, como a hipoglicemia. A secreção do GHRH e de somatostatina é estimulada por ação adrenérgica: receptores $\alpha 2$-adrenérgicos estimulam o GHRH, e a somatostatina é estimulada por receptores $\beta 2$-adrenérgicos. A 
secreção adenohipofisária do $\mathrm{GH}$ resulta do balanço entre estímulos inibidores e estimuladores (CATALDI et al., 1994; GIUSTINA; VELDHUIS, 1998).

Há que se levar em conta, na resposta do GH ao estresse, a influência estimuladora de fibras provenientes do complexo basolateral da amígdala e inibidoras provenientes da amigdala cortico-medial. Como parte das estruturas envolvidas com as emoções, a amigdala está certamente envolvida com a resposta do $\mathrm{GH}$ ao estresse. É importante também, nesta resposta, a relação existente entre a secreção de adrenalina e a resposta do $\mathrm{GH}$ via estimulação de receptores $\alpha 2$-adrenérgicos. A resposta do GH ao estresse parece depender, também, da ação central de adrenomedulina que aparentemente atua por meio da estimulação do CRH (TAYLOR; SAMSON, 2004). Outro fator a ser levado em conta na análise da resposta do GH ao estresse é a ritmicidade pulsátil da secreção do GH que difere segundo o sexo (GIUSTINA; VELDHUIS, 1998). A secreção do GH é estimulada por estrógenos, progesterona, testosterona, hormônios tireoidianos, TRH, sendo suprimido por glicocorticóides através de sua ação hipotalâmica.

Sob condições basais, se observa secreção de GH em níveis bastante baixos, mas pode apresentar picos espontâneos e muito intensos de secreção durante o dia, ao acaso. Esta manifestação pulsátil, no entanto, é mais freqüente durante as primeiras fases do sono e se manifestam de maneira consistentemente uniforme (WINER et. al., 1990).

\subsection{Transtorno do Estresse Pós-Traumático (TEPT)}

O TEPT, inicialmente definido como uma condição ligada a uma vivência decorrente de um trauma de guerra, atualmente inclui o segmento da população civil que apresenta o transtorno decorrente da exposição a uma série de traumas ou experiências traumáticas.

Estima-se em 9\% a prevalência do TEPT na população em geral (BRESLAU et al., 1991). Adicionalmente, a despeito do fato de as memórias traumáticas constituirem o componente central do TEPT, uma grande maioria de pacientes que apresentam queixas 
relativas a memórias traumáticas não preenche os critérios definidos pelo DSM-IV para o TEPT (DSM-IV, 1995). Assim, nem todos os indivíduos submetidos a traumas intensos desenvolvem o TEPT.

O TEPT é uma reação anormal a uma adversidade intensa.

Uma das principais características do TEPT é a ocorrência de emergência espontânea de memórias (flashbacks), que representam a revivescência espontânea do evento traumático, o que leva o indivíduo a sentir ou a agir como se estivesse novamente diante do fato gerador. O indivíduo também pode ser levado a evitar contextos relacionados com o trauma original, pode ter dificuldades para se lembrar de aspectos relacionados com o evento, ou pode apresentar menor interesse em participar de diversas atividades significativas: isto é, o estabelecimento de padrões de comportamento que levam à disfunção social do indivíduo. Podem existir, paralelamente, fenômenos de hiper-excitabilidade autonômica, alterações do ritmo normal do sono, surtos de raiva, dificuldades de concentração, elevado nível de vigilância e reatividade exacerbada a estímulos comuns.

É comum se observar inibição da resposta do eixo HPA no TEPT, que se manifesta por baixa excreção de cortisol urinário e plasmático (YEHUDA et al., 1995; RESNIK et al., 1995). Considera-se que essa inibição se deva à exacerbação da retroalimentação negativa exercida pelo cortisol sobre seus receptores, hipersensíveis, do hipocampo, hipotálamo e hipófise (GRAEFF, 2003). Pode ocorrer, também, redução da resposta do TSH ao estresse, possivelmente devida à retroalimentação negativa exercida pela elevação de T3 sérico (FRIEDMAN et al, 2005; WANG; MASON, 1999 ).

Discute-se se os achados de neuroimagem em pacientes portadores de TEPT que indicam volume hipocampal diminuído indicam um fator pré-disponente ao transtorno (GILBERTSON et al., 2002; SAPOLSKY, 2002), ou se são devidos à ocorrência de eventos estressores repetidos com ação de glicocorticóides sobre o hipocampo, levando à sua 
hipotrofia (SAPOLSKY, 1992). Ambos os pontos de vista suportam a hipótese de que seja possível que no continuum que vai da normalidade à manifestação plena do transtorno possam realmente existir estados intermediários (TEPT sub-clinico ou parcial). Estima-se que a prevalência destes estados intermediários seja de aproximadamente 30\% (WEISS et al., 1992).

É possível, portanto, que estes estados possam apresentar distúrbios de secreção hormonal semelhantes aos do TEPT.

\subsection{Recuperação de Memórias (Rec-Mem)}

A técnica de reestruturação vivencial é uma abordagem psicoterápica que utiliza a recuperação de memórias traumáticas no sentido de substituir parâmetros cognitivos e comportamentais que levam ao sofrimento, por outros, mais saudáveis, por meio de uma ação transformadora (re-significação, re-estruturação vivencial), objetivo final da técnica. É, assim, a técnica, essencialmente dirigida para instantes traumáticos do passado, no sentido de, ao se revivenciar os traumas, identifiquem-se os registros que definiram os padrões de comportamento perniciosos ao paciente e, por meio de sua resiliência, contribuir para mudança do comportamento.

A Terapia Reestruturativa Vivencial (TRV) é uma terapia de exposição e reestruturação cognitiva padronizada em manual (PERES et al., 2005) que inclui: 1. Sessão Introdutória, 2. Sessões de Anamnese, 3. Sessões Reestruturativas (SR) e 4. Sessões Integrativas (SI). São nas sessões reestruturativas que se obtém a Rec-Mem.

A técnica é realizada sob fundo musical instrumental clássico de fundo, de baixa intensidade, e a Rec-Mem é obtida por meio da indução de um estado modificado de 
consciência (EMC) que é pessoal, particular e subjetivo, assim como as vivências nele experimentadas.

As etapas de uma sessão de Rec-Mem (sessão re-estruturativa) obtida pela técnica são dez, específicas e consecutivas:

1. Relaxamento: o terapeuta conduz o paciente a descontrair-se de acordo com seqüência pré-estabelecida.

2. Aprofundamento: é obtido por meio da construção de imagens mentais escolhidas pelo paciente e induzidas pelo terapeuta e destina-se a obter um estado de maior relaxamento. Esse é um passo necessário para que se entre em contato com os conteúdos traumáticos em relação de causalidade com o problema atual. As etapas 1 e 2 são realizadas em aproximadamente 30 minutos.

3. Recuperação (ou "vivência"): o paciente reconstrói e revivencia fatos traumáticos de seu passado. É freqüente a ocorrência de vivências sobre as quais o paciente não tinha consciência em vigília; no entanto, representam conteúdo emocional genuíno e próprio do paciente em relação de causalidade com o tema que está sendo tratado.

4. Momento Mais Traumático (MMT): é identificado o MMT da vivência experimentada. Esse se dá sobre uma configuração composta por emoções, sentimentos, sensações e pensamentos, que definem o padrão negativo de seu comportamento que se relaciona causalmente com o problema atual. As etapas 3 e 4 são cumpridas em aproximadamente 60 minutos.

5. Decisão: é o conjunto de resoluções tomadas durante o evento gerador do trauma, identificadas durante o MMT. A "decisão" é um padrão de comportamento, negativo e repetitivo que influencia negativamente a vida do paciente, sendo expressa por uma frase, palavra ou expressão, que envolve emoções, sentimentos, sensações, pensamentos e 
comportamentos. Nessa fase, incentiva-se o paciente a estabelecer a relação existente entre a vivência e as suas dificuldades temáticas atuais.

6. Redecisão: baseia-se na conscientização e no processamento da vivência traumática, obtida durante a MMT e sua respectiva "decisão". Constitui-se na elaboração, pelo paciente, de uma frase cujo teor invalida o conteúdo negativo fixado na "decisão". Ela deve ser objetiva, afirmativa, o que constitui o texto representativo daquilo que o paciente realmente quer imprimir como mudança em sua vida: o início de um processo terapêutico auto-educativo (re-estruturação do significado).

7. Desprogramação: o paciente se desvincula das emoções, sentimentos e sensações negativas experimentados durante a vivência traumática, por meio de mensagens verbalizadas pelo terapeuta, baseadas na "redecisão", que representam os melhores propósitos pessoais do paciente, o que reforça a compreensão de suas características pessoais.

8. Programação Positiva: visa a registrar, por visualização criativa de uma situação concreta na qual coloca em prática o novo comportamento, o conceito da "redecisão". O paciente é levado a imaginar uma situação na qual esteja diante da iminência de repetir a “decisão", sendo então estimulado a colocar a "redecisão" em prática.

9. Retorno: visa à superficialização do relaxamento e à recondução ao estado anterior de vigília.

10. Finalização: retomada da plena consciência de cada segmento corporal previamente relaxado, complementando o retorno ao seu estado anterior de vigília.

O terapeuta reforça a redecisão tomada na sessão, assim como o estado de equilíbrio físico e mental do paciente. As etapas de 5 a 10 são realizadas em aproximadamente 30 minutos. 


\subsection{Conclusão}

Podemos resumir as respostas relativas aos estressores (estressor entendido como qualquer ameaça à integridade física do ser ou que é percebido como tal), em três situações gerais:

1. condições externas resultantes de dor e desconforto;

2. distúrbios homeostáticos internos;

3. respostas associativas ou aprendidas à percepção de ameaça de perigo, de dor ou de desconforto (estresse psicológico)

Os circuitos neurais específicos e os sistemas de neurotransmissão envolvidos com essas respostas parecem diferir para cada sistema neuroendócrino e categoria de estressor (VAN DE KAR; BLAIR, 1999).

Do um ponto de vista do estresse psicológico, também temos três situais gerais.

1. uma situação relacionada com um estímulo ambiental (realidade objetiva) ao qual se responde inicialmente por meio de mudança comportamental, depois por uma ativação autonômica e, finalmente, por meio do sistema neuroendócrino, visando à manutenção da homeostase interna. O hodograma neural de tais respostas relaciona o estressor, via órgãos dos sentidos, com diversas porções do córtex cerebral e suas conexões com o giro cíngulo, com o complexo hipocampo-amigdalóide e suas conexões com o hipotálamo (sistema septohipocampal, rafe), com as vias de "saída do sinal” envolvendo o núcleo intersticial da estria terminal, a matéria cinzenta periaquedutal, o sistema nervoso autônomo e o sistema endócrino.

2. as manifestações emocionais e as alterações hormonais observadas no TEPT, com a ocorrência espontânea de memórias traumáticas e/ou de material relativo a vivências 
impossíveis de terem sido experimentadas pelo indivíduo durante a sua vida, que são atribuíveis ao intenso trauma, originador do transtorno.

3. o que ocorre em sonhos de caráter ameaçador (pesadelos), nos quais se observam, pelo menos, manifestações clínicas de ativação autonômica relacionadas com o conteúdo manifesto do sonho e sua constelação emocional.

Neste momento, cabe a seguinte pergunta:

Ocorrerão respostas autonômicas e/ou neuroendócrinas à obtenção intencional de vivências relativas a memórias traumáticas experimentadas pelo indivíduo?

A resposta a esta pergunta é o objetivo central desta dissertação.

Dadas as complexidade e imprevisibilidade da manifestação psíquica envolvida com os fenômenos de Rec-Mem, torna-se trabalhosa a construção de um modelo científico convencional para estudar estes fenômenos devido às dificuldades de se estabelecer a natureza e a forma de controle das variáveis a serem estudadas.

$\mathrm{Na}$ tentativa de responder a estas questões, imaginou-se um experimento envolvendo sujeitos submetidos aos processos de Rec-Mem com coleta simultânea de material destinado a dosagens hormonais. 
A liberdade do pensamento é a base de toda a criatividade.

2. OBJETIVOS 


\section{Objetivos}

Determinar os aspectos quantitativos e qualitativos das respostas autonômicas e neuroendócrinas em seis sujeitos submetidos aos procedimentos de recuperação de memórias traumáticas (Rec-Mem). 
Quem reclama por falta de tempo é porque perde tempo por falta de método.

(Renato Kohl)

3. MATERIAL E MÉTODOS 


\subsection{Sujeitos:}

Seis voluntários, três homens e três mulheres, de diferentes idades. Mulheres com 31, 46 e 49 anos e homens com 25,52 e 59 anos.

\subsection{Consentimento}

Todos os procedimentos foram realizados em obediência à resolução 196/96 do Conselho Nacional de Saúde e ao artigo 129 do Código de Ética Médica. Houve consentimento prévio e esclarecido dos seis voluntários de ambos os sexos. Protocolo aprovado pela Comissão de Ética do Instituto Nacional de Pesquisa e Terapia Reestruturativa Vivencial Peres, em 3 de agosto de 2000 (ANEXOS).

\subsection{Condição médica dos sujeitos}

Não eram portadores de moléstias endócrinas e metabólicas reconhecíveis por anamnese e por exame clínico, ou outras, crônicas e/ou descompensadas, hipertensão arterial, psicose ou história prévia de surto psicótico. Não tinham estado sob efeito de nenhum medicamento pelas últimas oito semanas, incluindo os de ação sobre o sistema nervoso central e o sistema endócrino. Os sujeitos do sexo feminino estavam no menacme e foram avaliados na primeira fase do ciclo menstrual.

\subsection{Ambiente}

Em ambas as condições, o procedimento se deu em sala apropriada para TRV e coleta de material, com divã confortável, silenciosa, sob música clássica instrumental suave de fundo, em penumbra (iluminação indireta por lâmpada incandescente de 40 watts, com foco dirigido para a poltrona do terapeuta, situada na cabeceira do divã, do lado esquerdo do sujeito). Temperatura controlada em 25 graus centígrados. 


\subsection{Experimento:}

Os procedimentos foram todos realizados rigorosamente no mesmo horário, no sentido de se evitar a influência dos ritmos circadianos dos diferentes hormônios nos resultados.

\subsubsection{Condição Controle (CC):}

Cada um dos sujeitos chegou ao laboratório aproximadamente no mesmo horário (por volta das 7:30 h), após refeição leve. Após a coleta de chegada ao laboratório, os sujeitos foram colocados em decúbito dorsal, em repouso, condição em que permaneceram por duas horas, em vigília, de olhos abertos, em silêncio, sem manter conversação com o pessoal em sala, tempo de referência suficiente para a realização dos procedimentos padrão de recuperação de memórias traumáticas segundo a TRV. O material foi obtido por punção venosa em veia de prega do cotovelo do membro superior direito, seguida por instalação e imobilização de coletor apropriado ("scalp”) com esparadrapo (Vacutainer Safety Lock Benton \& Dickinson Vacutainer Systems, - 0,8x19,0x178,0 mm), seguida de infusão de 0,5 ml de heparina a $1 \%$ em soro fisiológico. Em cada amostra, desprezou-se $1,0 \mathrm{ml}$ de sangue aspirado por seringa de 20,0 ml. Em seguida, colheu-se 7,0 $\mathrm{ml}$ de sangue em tubo de vidro (vacutainer) com 0,9 g EDTA $+0,7$ g GSH mantido previamente entre 0 e -10 graus centígrados e, posteriormente, $10,0 \mathrm{ml}$ de sangue em tubo seco (vacutainer). Após cada coleta, o coletor foi novamente heparinizado por infusão de $0,5 \mathrm{ml}$ de heparina a $1,0 \% \mathrm{em}$ solução fisiológica e, entre as coletas, submetido a pequenas lavagens com o soro heparinizado. Esse procedimento foi seguido em todas as coletas. Às 7:30 h, precisamente, foram colhidas amostras em situação de sala de espera segundo o procedimento descrito acima. Precisamente às 8:00 $\mathrm{h}$, colheu-se a primeira amostra de uma série de dez, incluindo a amostra de chegada, cada uma colhida a intervalos de 15 minutos. Durante todo o procedimento, foram mantidos em sala: observador 1: sentado na poltrona do terapeuta., observador 2: responsável técnico pelas coletas e observador 3: para a anotação sobre as 
condições dos sujeitos e de eventuais ocorrências. Os observadores permaneceram em silêncio durante todo procedimento, com movimentação mínima indispensável ao exercício de suas atividades.

\subsubsection{Condição de Recuperação (CR):}

As condições de realização dos procedimentos de TRVP na CR foram as mesmas descritas para a CC, com exceção de que, a partir das 8:00 h, coincidente com a primeira coleta, iniciaram-se os procedimentos de TRV, que se encerraram duas horas depois. O intervalo entre a $\mathrm{CC}$ e a $\mathrm{CR}$ nos sujeitos de sexo masculino foi de sete dias, e de cinco semanas para os sujeitos de sexo feminino. Nenhum evento significativo ou digno de nota foi identificado durante estes intervalos para ambos os sexos.

Apenas o observador 1 foi substituído pelo mesmo terapeuta para todos os sujeitos.

\subsection{Dosagens Hormonais:}

3.6.1. ACTH: radioimunoensaio (Immunlite ACTH - Diagnostic Products Corporation). Valores de Referência: 0-130 pg/ml pg/ml a 95\% às 09:00 h da manhã. Unidades de medida: pg/ml. Coeficiente de variação intra-ensaio: 7 a $16 \%$.

3.6.2. Adrenalina: HPLC (Clin Rep-Chemicals Instruments GmBH). Sensibilidade do teste: 10 a $2500 \mathrm{ng} / \mathrm{l}$. Valores de referência: 0-140,0 pg/ml. Coeficiente de variação intraensaio médio $7,6 \%$.

3.6.3. Cortisol: quimioluminescência (Cortisol ADVIA Centaur- Bayer Corporation). Sensibilidade do teste: 0,20-75 ug/dl. Valores de referência: 4,30-22,40 ug/dl a 95\% entre 07:00 e 09:00 h da manhã). Coeficiente de variação intra-ensaio: 3,69 \% para média de 3,88 ug/dl, 3,09\% para média de 5,63 ug/dl, 2,89\% para média de 14,17 ug/dl, 3,82\% para média de $27,53 \mathrm{ug} / \mathrm{dl}$ e $2,98 \%$ para média de 37,15 ug/dl (5 amostras sendo analisadas por 6 vezes em 24 corridas, em 6 sistemas, com $n=144$ para cada amostra, durante um período de 2 dias). 
3.6.4. Prolactina: quimioluminescência (Prolactin ADVIA Centaur - Bayer Corporation). Sensibilidade do teste: 0,3 a 200,0 ng/ml. Valores de referência: 3-18 ng/ml. Coeficiente de variação intra-ensaio: 3,3\% para média de 2,7 ng/ml, 2,3\% para média de 6,9 $\mathrm{ng} / \mathrm{ml}, 2,8 \mathrm{ng} / \mathrm{ml}$ para média de 10,4 ng/ml, 2,7 ng/ml para média de $23,7 \mathrm{ng} / \mathrm{ml}, 2,9 \%$ para média de 457,3 ng/ml e 3,2\% para média de 116,8 ng/ml (6 amostras analisadas por 6 vezes em 12 corridas em 3 sistemas, com $n=72$ para cada amostra, durante um período de 2 dias).

3.6.5. TSH: quimioluminescência (TSH ADVIA Centaur-Bayer Corporation). Valores de referência: 0,35-5,5 $\mu \mathrm{IU} / \mathrm{ml}$ Coeficiente de variação intra-ensaio: 2,48\% para média de 0,74uIU/ml, 2,44\% para média de 5,65 uIU/ml e 2,41\% para média de $18,98 \mathrm{uIU} / \mathrm{ml}$ (3 amostras analisadas por 6 vezes em 18 processamentos em 6 sistemas, com $n=108$ para cada amostra, durante um período de 10 dias).

3.6.6. GH: quimioluminescência (Immulite $h G H$ - Euro/DPC Ltd) Valores de referência: 0,06-5,0 ng/ml. Coeficiente de variação intra-ensaio: $8 \%$. Sensibilidade analítica: $0,01 \mathrm{ng} / \mathrm{ml}$.

\subsection{Procedimentos e testes prévios ao experimento}

3.7.1. SCID - 1/P, com resultados submetidos aos critérios do DSM-IV (DSM-IV, 1995)

\subsubsection{Escala Hamilton de Ansiedade}

\subsubsection{BDI - Inventário Beck de Depressão}

3.8. Questionário para Identificação de Indivíduos Matutinos e Vespertinos do Grupo Multidisciplinar de Desenvolvimento e Ritmos Biológicos (GMDRB) do Departamento de Fisiologia e Biofísica do Instituto de Ciências Biomédicas da Universidade de São Paulo (traduzido e adaptado de Horne e Ostberg (HORNE; OSTBERG, 1976), no sentido de se avaliar a interferência da variação de diferentes ritmos circadianos de secreção hormonal sobre os resultados). 


\subsection{Análise estatística dos resultados}

Os resultados, tomados individualmente para cada hormônio em cada condição (CC e CR), foram submetidos ao Teste C (“C-statistcs”) (YOUNG, 1941; TRYON, 1982), aplicável para a análise de séries temporais em casos individuais.

Dado que as CC e CR para cada sujeito foram realizadas com intervalo de sete dias para os sujeitos do sexo masculino e cinco semanas para os sujeitos do sexo feminino, não foi aplicado o C-teste para a análise comparativa das curvas de cada hormônio em ambas as condições $(\mathrm{CC}$ e $\mathrm{CR})$, por não terem sido consecutivas, limitando-se somente à análise de cada curva de secreção hormonal em cada condição individualmente..

Por isso, adicionalmente, para a comparação da secreção total de cada hormônio de cada sujeito em ambas as condições ( $\mathrm{CC}$ e $\mathrm{CR}$ ), os resultados foram submetidos, seqüencialmente, aos Testes de Bartlett, Kruskal-Wallis (ANOVA) e, finalmente, MannWhitney, não pareado, não paramétrico (U-teste) para a comparação de médias secreção hormonal $(\mathrm{p}<0,05)$. 
Alea jacta est!

(Júlio César, no Rubicão)

4. RESULTADOS 
As emoções, sentimentos e sensações experimentados pelos sujeitos durante as vivências obedecem à ordem cronológica com que surgiram e foram relatadas pelos sujeitos e podem ser vistos na Tabela VIII (ANEXOS).

Os resultados das avaliações prévias aos procedimentos podem ser vistos na tabela VII (ANEXOS).

Os fenômenos hormonais observados são exibidos por meio de gráficos expressando curvas de tempo e resposta em ambas as condições (CC e CR, figuras de 1 a 18). Dado que as curvas das CC e CR se situam em patamares diferentes em muitos dos sujeitos pelo fato de terem sido obtidas em dias diferentes (intervalos de sete dias para os sujeitos do sexo masculino e cinco semanas para os sujeitos do sexo feminino), foi feito o rescalonamento das curvas para a sua variação relativa a partir de um valor igual a 1 obtido pela divisão de todos os valores das séries temporais pelo valor observado no instante 0 em ambas as condições. Este rescalonamento tem a vantagem de revelar aspectos das curvas de secreção hormonal que não são detectáveis pela simples expressão de seus valores absolutos.

4.1. SUJEITO 1 - CMM - sexo feminino, 49 anos. Diagnóstico pelo SCID/DSM-IV: Transtorno de Ansiedade Generalizado (TAG) (300.02). BDI =0. HAM-A: $<17$. Tipo Matutino do GMDRB.

Resumo: instante 0: início do Relaxamento. 35 minutos: fim do Relaxamento e início do Aprofundamento. 40 minutos: fim do Aprofundamento. A partir dos 40 minutos, Recuperação, quando ocorrem as vivências. 45 minutos aos 60 minutos: MMT. 75 minutos: identificação da Decisão e Redecisão. 90 minutos, inicia-se a Desprogramação. 100 minutos: Programação Positiva. 105 minutos: início do Retorno e Finalização.

Resultados das dosagens hormonais: a Tabela I mostra os resultados das dosagens hormonais realizadas no sujeito 1 , em ambas as condições (CC e CR). 


\section{TABELA I}

Resultados do sujeito 1 - dosagens hormonais, médias, desvios padrão, erros padrão, medianas e intervalos de confiança CC - condição controle $\quad$ CR - condição de recuperação DP - desvio padrão $\quad$ EP - erro padrão $\quad$ IC - intervalo de confiança

Os cálculos estatísticos foram realizados utilizando-se os valores observados entre os instantes de 0 e 120 minutos.

\begin{tabular}{|c|c|c|c|c|c|c|c|c|c|c|c|c|}
\hline $\begin{array}{l}\text { Tempo } \\
\text { min }\end{array}$ & $\begin{array}{c}\text { ACTH-CC } \\
\mathrm{ng} / \mathrm{ml}\end{array}$ & $\begin{array}{l}\text { ACTH-CR } \\
\mathrm{ng} / \mathrm{ml}\end{array}$ & $\begin{array}{c}\text { ADR-CC } \\
\mathrm{pg} / \mathrm{ml}\end{array}$ & $\begin{array}{c}\text { ADR-CR } \\
\mathrm{pg} / \mathrm{ml}\end{array}$ & $\begin{array}{c}\text { CORT-CC } \\
\text { ug/dl }\end{array}$ & $\begin{array}{c}\text { CORT-CR } \\
\text { ug/dl }\end{array}$ & $\begin{array}{c}\text { PRL-CC } \\
\text { ng/ml }\end{array}$ & $\begin{array}{c}\text { PRL-CR } \\
\mathrm{ng} / \mathrm{ml}\end{array}$ & $\begin{array}{c}\text { TSH-CC } \\
\mathrm{uUI} / \mathrm{ml}\end{array}$ & $\begin{array}{l}\text { TSH-CR } \\
\mathrm{uUl} / \mathrm{ml}\end{array}$ & $\begin{array}{l}\mathrm{GH}-\mathrm{CC} \\
\mathrm{ng} / \mathrm{ml}\end{array}$ & $\begin{array}{c}\mathrm{GH}-\mathrm{CR} \\
\mathrm{ng} / \mathrm{ml}\end{array}$ \\
\hline-30 & 63,00 & 150,00 & 25,00 & 55,00 & 30,40 & 32,00 & 11,70 & 14,00 & 1,80 & 1,00 & 4,50 & 2,00 \\
\hline 0 & 55,00 & 118,00 & 29,00 & 44,00 & 11,30 & 15,90 & 17,60 & 14,70 & 1,50 & 0,82 & 3,90 & 2,60 \\
\hline 15 & 73,00 & 75,00 & 36,00 & 44,00 & 9,10 & 15,70 & 12,60 & 15,30 & 0,96 & 1,70 & 2,40 & 1,90 \\
\hline 30 & 5,00 & 3,00 & 24,00 & 66,00 & 8,80 & 13,00 & 10,30 & 9,80 &, 56 & 0,60 & 2,10 & 1,90 \\
\hline 45 & 75,00 & 134,00 & 25,00 & 21,00 & 12,20 & 10,90 & 19,40 & 8,10 & 0,34 & 0,91 & 1,80 & 1,80 \\
\hline 60 & 65,00 & 125,00 & 21,00 & 160,00 & 8,60 & 15,90 & 13,30 & 23,10 & 0,49 & 0,71 & 1,70 & 2,00 \\
\hline 75 & 80,00 & 111,00 & 36,00 & 121,00 & 10,50 & 15,60 & 10,70 & 29,40 & 0,40 & 1,20 & 1,90 & 2,10 \\
\hline 90 &, 00 & & 1,00 & 40 & 8,30 & 11,60 & 9,40 & 14,70 & 0,41 & 1,20 & 1,90 & 1,90 \\
\hline 105 & 00 & 00 & 55,00 & 31,00 & 6,30 & 12,40 & 10,70 & 15,40 & 1,00 & 1,50 & 1,80 & 1,80 \\
\hline 120 & 53,00 & 93,00 & 40,00 & 14,00 & 6,60 & 5,50 & 11,80 & 11,40 & 0,08 & 1,40 & 1,70 & 1,70 \\
\hline Média & 65,6670 & 106,7800 & 34,4440 & 60,1110 & 9,0780 & 12,9440 & 12,8670 & 15,7670 & 0,6378 & 1,1160 & 2,1330 & ,9670 \\
\hline DP & 10,3320 & 25,3220 & 10,9440 & 48,9220 & 1,9840 & 3,4250 & 3,4370 & 6,6680 & 0,4351 & 0,3782 & 0,6982 & 0,2646 \\
\hline EP & 3,4440 & 8,4410 & 3,6480 & 16,3070 & 0,6612 & 1,1420 & 1,1460 & 2,2230 & 0,1450 & 0,1261 & 0,2327 & 0,0882 \\
\hline Mediana &, 0000 & 111,0000 & 36,0000 & 44,0000 & 8,8000 & 13,0000 & 11,8000 & 14,7000 & 0,4900 & 1,2000 & 1,9000 & 1,9000 \\
\hline $\mathrm{IC}<95 \%$ & 57,7250 & 87,3140 & 26,0320 & 22,5060 & 7,5530 & 10,3120 & 10,2250 & 10,6410 & 0,3033 & 8,4280 & 1,5970 & 1,7630 \\
\hline IC >95\% & 73,6090 & 126,2400 & 42,8570 & 97,7160 & 10,6020 & 15,5770 & 15,5080 & 20,8920 & 0,9722 & 1,4060 & 2,6700 & 2,1700 \\
\hline
\end{tabular}


A

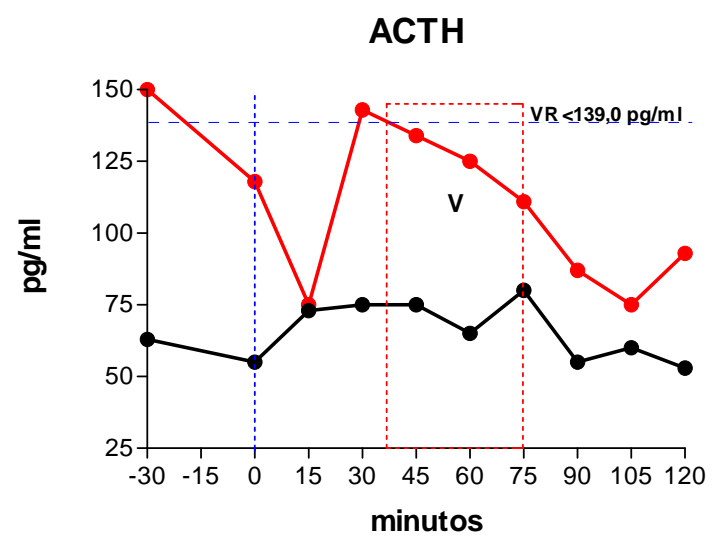

C

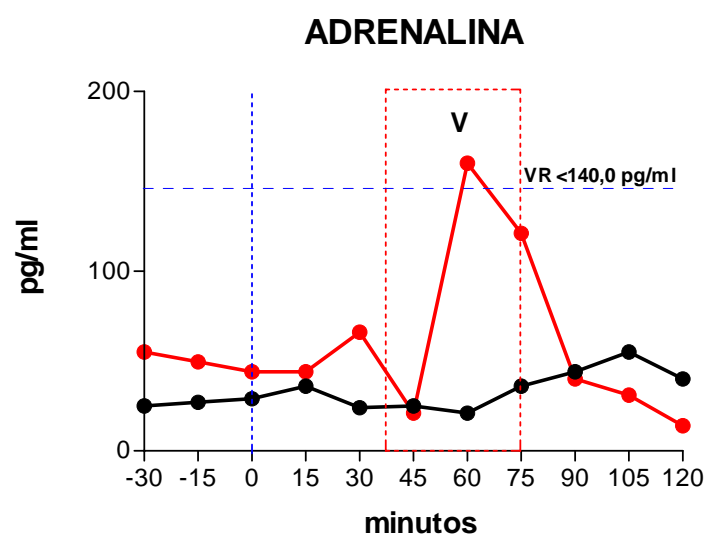

$\mathbf{E}$

TSH

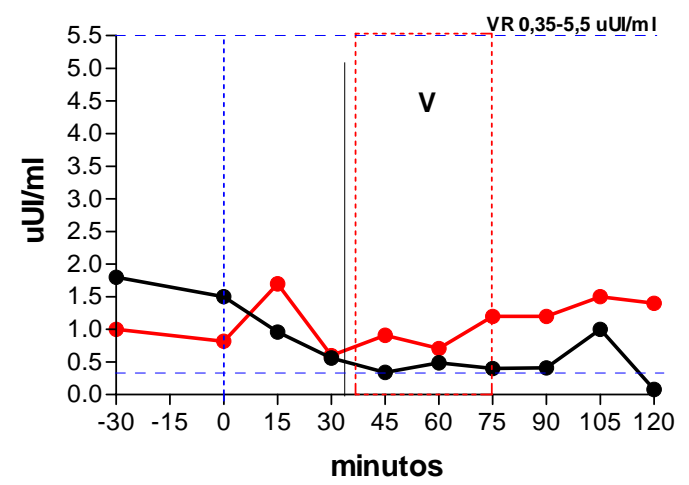

B

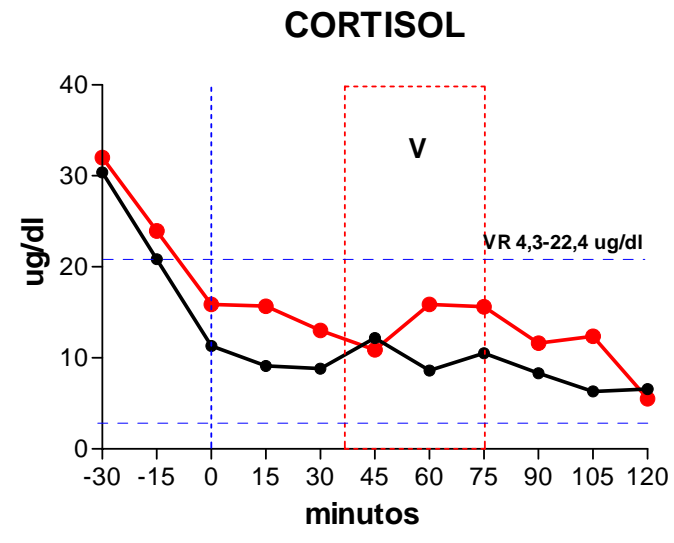

D

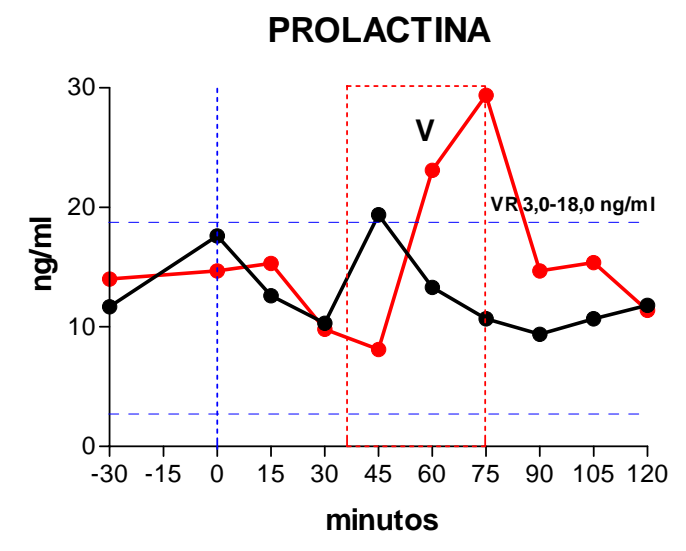

$\mathbf{F}$

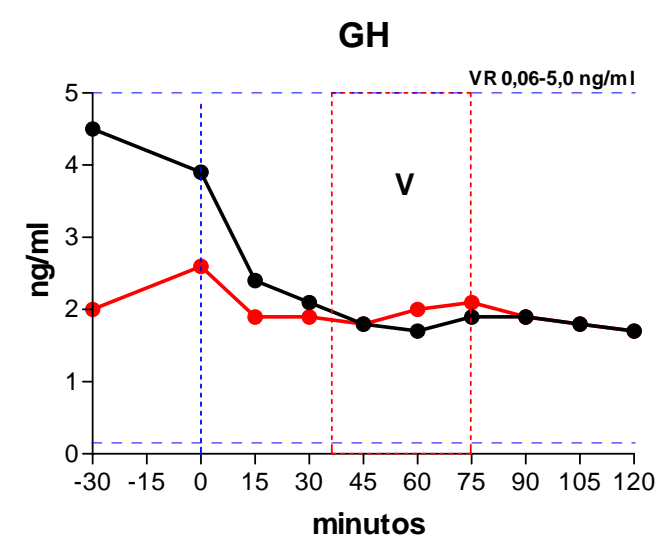

Figura 1 - curvas de tempo e resposta das variações hormonais do sujeito 1 submetido à recuperação de memórias traumáticas, .

$\bullet-\bullet$ - condição controle (CC).

$\bullet-\bullet$ - condição de recuperação (CR).

V - vivência.

VR - valores de referência para o ensaio 
A

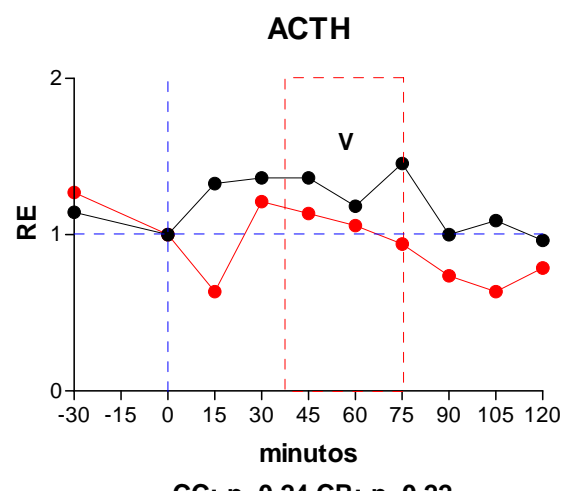

CC: $p=0,24$ CR: $p=0,22$

C

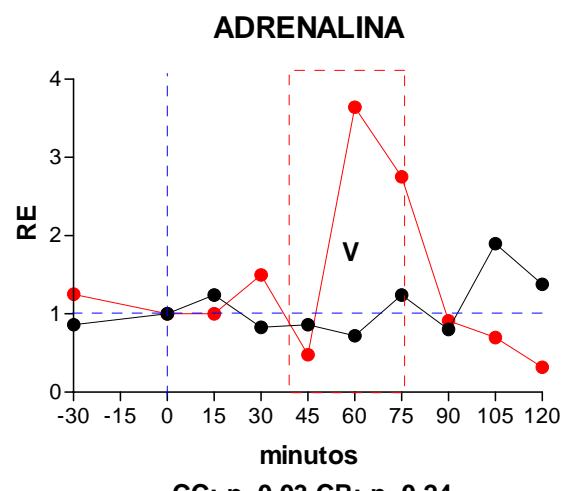

CC: $p=0,03$ CR: $p=0,24$

$\mathbf{E}$

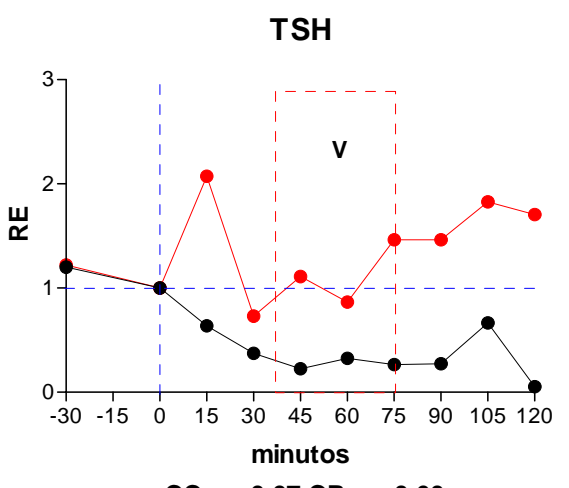

CC: $p=0,07$ CR: $p=0,60$
B

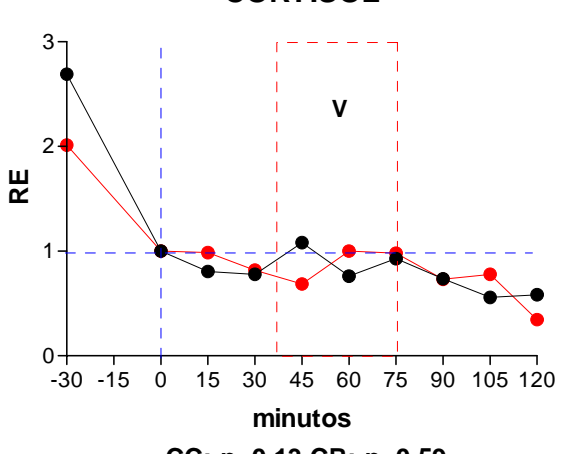

CC: $p=0,13$ CR: $p=0,59$

D

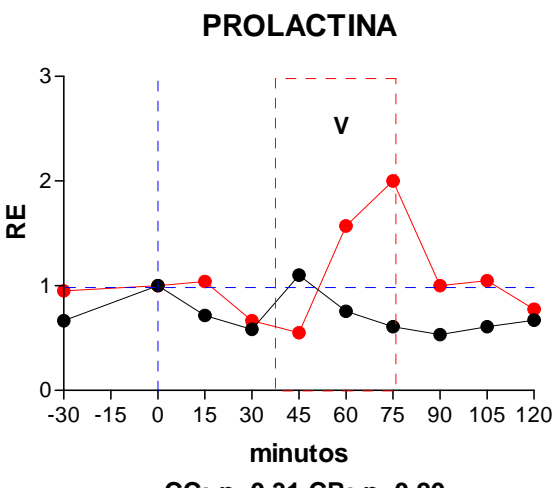

$\mathbf{F}$

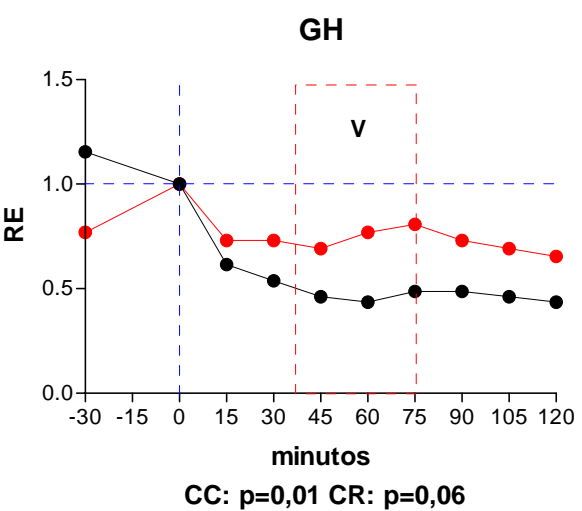

Figura 2 - curvas rescalonadas de tempo e resposta das variações hormonais do sujeito 1 submetido à recuperação de memórias traumáticas.

$\bullet-\bullet$ - condição controle (CC).

$\bullet-\bullet$ - condição de recuperação (CR).

V - vivência. 
A

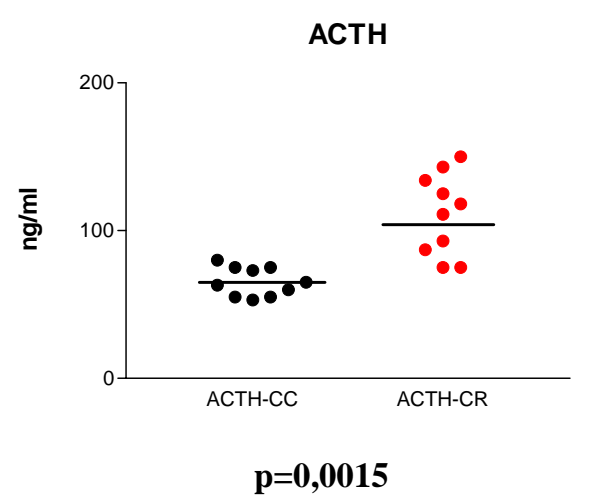

C

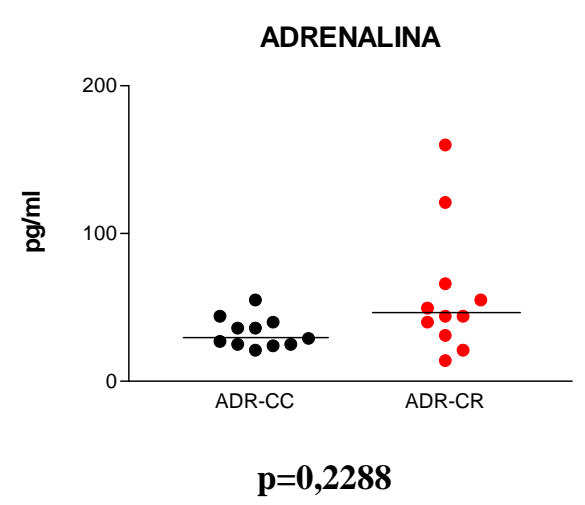

$\mathbf{E}$

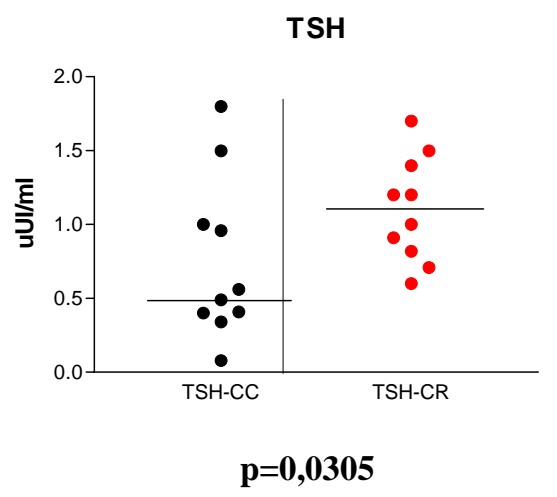

B

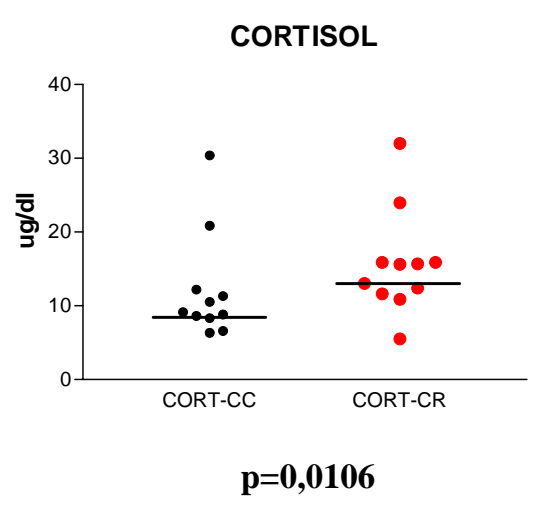

D

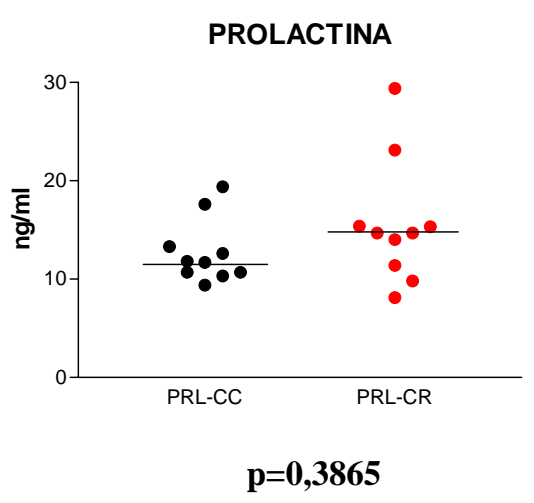

$\mathbf{F}$

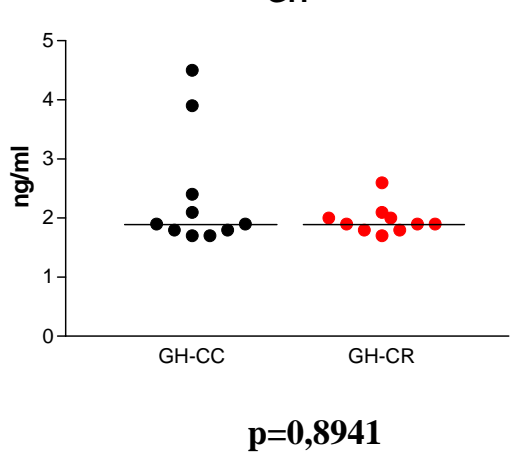

Figura 3 - variações hormonais em função do tempo do sujeito 1 submetido à recuperação de memórias traumáticas, expressas em medianas.

Mann-Whiney, $\mathrm{U}$ teste, $\mathrm{p}<0,005$.

$\bullet-\bullet$ - condição controle (CC).

$\bullet-\bullet$ - condição de recuperação (CR). 
Gráficos representativos das dosagens hormonais: as figuras 1, 2 e 3 exibem os gráficos representativos das variações hormonais observadas em ambas as condições (CC e CR).

Descrição das curvas de secreção hormonal: as condições de chegada ao laboratório na CC e na CR são expressas pelos valores observados aos -30 minutos.

\subsubsection{ACTH}

Condição Controle (CC): após o repouso de trinta minutos, o nível de ACTH se mantém praticamente constante até o final dos procedimentos.

Condição de Recuperação (CR): os níveis de ACTH na condição de chegada ao laboratório são cerca de duas vezes e meio mais elevados do que os observados na CC. Entre os instantes -30 minutos e 0 minuto, ocorre queda de $21,33 \%$ na secreção hormonal, que continua em queda constante até os 15 minutos, quanto atinge os níveis observados na $\mathrm{CC}$, o que representa uma queda de $50 \%$ em relação ao instante 0 . Entre os 15 e os 30 minutos ocorre elevação de $90,6 \%$ em relação ao tempo de 15 minutos, atingindo valores praticamente iguais aos da condição de chegada. A seguir, observa-se queda lenta e constante da secreção hormonal, que continua durante a vivência, até os 105 minutos, quando se iguala aos valores observados na CC, representando queda de 46,9\% em relação ao nível observado aos 30 minutos. No final dos procedimentos, ocorre elevação de $24 \%$ do nível de ACTH em relação aos 105 minutos.

\subsubsection{Cortisol}

Condição controle (CC): o nível de secreção hormonal na condição de chegada ao laboratório (-30 minutos) se situa acima dos limites superiores dos valores de referência para o ensaio. Após o repouso de 30 minutos, observa-se queda da secreção hormonal para valores dentro dos limites dos valores de referência para o ensaio. A secreção do cortisol se mantém 
em queda, com pequenas oscilações, atingindo, no final dos procedimentos, valores cerca de $44 \%$ mais baixos do que os observados no instante 0 .

Condição de Recuperação (CR): o nível de secreção hormonal na condição de chegada ao laboratório é coincidente com o observado na CC. Após o repouso de 30 minutos, o nível de secreção hormonal da CR é de 16,81 \% acima dos observados na CC. A partir daí, ocorre queda gradual de secreção hormonal igualando-se à curva da $\mathrm{CC}$ aos 45 minutos, o que representa uma queda de $31,44 \%$ a partir do instante 0 . Entre os instantes de 45 e 60 minutos, ocorre um incremento de 45,87 \% na secreção hormonal, o que se iguala aos valores observados no instante 0. A partir daí, ocorre queda lenta e progressiva da secreção hormonal até os 120 minutos, quando se iguala aos valores observados na CC.

\subsubsection{Adrenalina}

Condição controle (CC): o nível de secreção hormonal observado aos -30 minutos não se altera após o repouso e apresenta uma queda total de $27,58 \%$ entre os instantes 0 e 60 minutos, quando mostra discreta elevação, até os 105 minutos, representando $61 \%$ mais do que os níveis observados aos 60 minutos, e $89 \%$ maior em relação ao instante 0 minuto. No fim dos procedimentos, aos 120 minutos, ocorre queda de $27,27 \%$ em relação ao valor observado aos 105 minutos, mas 37,93\% mais elevados do que o observado no instante 0 .

Condição de Recuperação (CR): a secreção hormonal aos -30 minutos é 54 \% maior do que na $\mathrm{CC}$, com queda subseqüente até atingir valores muito próximos dos observados na CC aos 15 minutos. A partir de então, ocorre um pico de secreção hormonal aos 30 minutos ( $50 \%$ entre os instantes de 15 e 30 minutos). A isso se segue uma queda de secreção hormonal para valores um pouco menores do que os observados aos 45 minutos na CC. A partir desse ponto, observa-se um pico muito intenso de secreção entre os 45 e os 60 minutos, o que representa um incremento de 263, 63 \% em relação ao instante de 0 minuto e $661,9 \%$ em relação aos 45 minutos. A partir de então, ocorre queda rápida dos níveis de secreção 
hormonal, que atingem valores ainda menores do que os observados na $\mathrm{CC}$, constituindo uma queda de $68,18 \%$ em relação ao instante 0 e a menos de $10 \%$ dos valores observados aos 60 minutos.

\subsubsection{Prolactina}

Condição Controle (CC): após o repouso, observa-se elevação da secreção hormonal de 50,42\% em relação ao instante de chegada. A seguir, ocorre queda progressiva da secreção hormonal até os 30 minutos o que representa uma queda de $58,52 \%$ em relação ao instante 0 . A partir desse instante, ocorre um pico de secreção máximo, observado aos 45 minutos, com um incremento de 88,34 \% em relação ao instante de 30 minutos. Então, ocorre queda de 51,54 \% na secreção hormonal entre 45 e 90 minutos, seguida por uma lenta ascensão até o final dos procedimentos, com um incremento de $25,53 \%$ em relação ao instante 90 minutos.

Condição de Recuperação (CR): a secreção hormonal aos -30 minutos é 19,65\% mais elevado do que na CC. A secreção de prolactina se mantém constante até os 15 minutos, apresentando queda que atinge, aos 45 minutos, os valores mais baixos observados durante os procedimentos: $44,98 \%$ mais baixos em relação ao instante 0 . A partir desse instante, ocorre uma intensa elevação dos níveis de prolactina: aos 60 minutos, um incremento de $185 \%$ em relação aos 45 minutos e, aos 75 minutos, um incremento de 22,94\% em relação aos 60 minutos e 262,9 \% em relação aos 45 minutos. Então, ocorre queda rápida de secreção, seguida por uma pequena fase de relativa estabilidade e, assim, as curvas CC e CR novamente se tocam no fim dos procedimentos, aos 120 minutos.

\subsubsection{TSH}

Condição Controle (CC): entre os instantes de -30 e 0 minutos ocorre uma queda de $36 \%$ na secreção do TSH, a qual continua lenta e progressivamente até atingir valores de relativa estabilidade o que ocorre aos 45 minutos, com queda de $64,58 \%$ em relação ao instante 0 . Essa estabilidade se mantém até os 90 minutos, quando apresenta um pico de 143,9 
$\%$, aos 105 minutos, reduzindo-se aos 120 minutos, quando se observam os valores mais baixos observados nessa condição (queda total de $94,66 \%$ entre 0 e 120 minutos).

Condição de Recuperação (CR): a secreção de TSH aos -30 minutos é cerca de 50\% mais baixa do que a observada na CC. Entre -30 e 0 minutos, observa-se queda de 16,66 \% de secreção hormonal. A partir daí, observa-se um comportamento oscilante da secreção do TSH, com picos e depressões: um primeiro pico aos 15 minutos (incremento de 107,3\% em relação ao instante 0 ), com oscilações subseqüentes de $64,7 \%$ para menos, $51,66 \%$ para mais e $21,97 \%$ para menos, aos 30,45 e 60 minutos, seguido por estabilidade que se prolonga por 30 minutos (75 e 90 minutos), e, a seguir, nova oscilação de $25 \%$ para mais e 6,66\% para menos. Os instantes de 30 e 60 minutos, nas curvas $\mathrm{CC}$ e CR, equivalem-se.

\subsubsection{GH}

Condição Controle (CC): a partir da condição de chegada ao laboratório, observa-se queda de $13,3 \%$ para o instante 0 , início dos procedimentos. A secreção hormonal permanece em queda até os 45 minutos, representando uma redução de 48,7 \% em relação ao instante 0 , quando então se estabiliza até o final dos procedimentos, aos 120 minutos.

Condição de Recuperação (CR): o nível de secreção do GH aos -30 minutos são $55,5 \%$ menores do que na CC, seguidos por elevação de $50 \%$ até o instante 0 . A partir desse momento, a curva $\mathrm{CR}$ segue, ponto a ponto, a curva $\mathrm{CC}$ até o final dos procedimentos, aos 120 minutos.

\section{Análise estatística}

Os resultados da análise estatística acham-se expressos no Quadro I.

4.2. SUJEITO 2 - APVR - sexo feminino, 31 anos. Diagnóstico pelo SCID/DSM-IV: Fobia Social (300.23) - BDI = 08. HAM-A 17. Tipo Matutino do GMDRB.

Resumo: instante 0: início do Relaxamento. 25 minutos: início do Aprofundamento. Dos 38 minutos aos 75 minutos: ocorrem as vivências 1 e 2. Aos 81 minutos: identificação da 
QUADRO I - Sujeito 1 - valores de $\boldsymbol{p}$ : C-teste, Mann-Whitney ( U-teste), p<0,05.

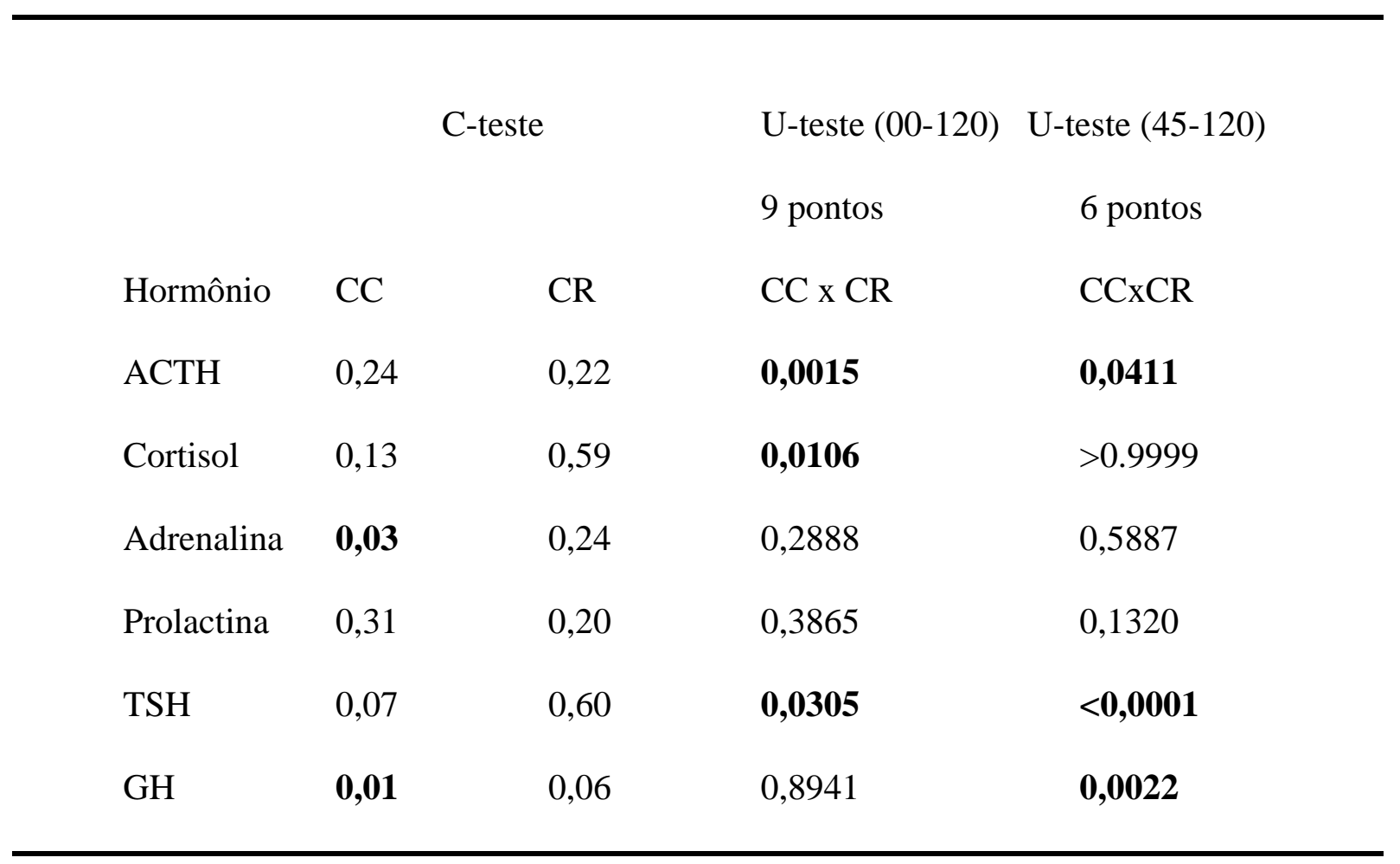

Em negrito, os resultados estatisticamente significativos.

00-120 - (minutos) intervalo de valores utilizados para a análise estatística 45-120 - (minutos) intervalo de valores utilizados para a análise estatística 
Decisão e Redecisão. Aos 92 minutos, inicia-se a Desprogramação. Aos 108 minutos: iniciase a Programação Positiva. Aos110 minutos: início do Retorno e Finalização.

Observações: na condição controle (CC), o sujeito referiu ter se emocionado com lembranças sobre as quais não conseguiu, posteriormente, se recordar. Durante todas fases da CR o sujeito permaneceu em repouso e não se observou agitação psicomotora. No final dos procedimentos, o sujeito se sentia bem, orientado no espaço e no tempo, com bom contacto com o ambiente. Foi submetido a acompanhamento psicoterápico subseqüente.

Resultados das dosagens hormonais: a Tabela II mostra os resultados das dosagens hormonais realizadas no sujeito 2, em ambas as condições (CC e CR).

Gráficos representativos das dosagens hormonais: as figuras 4, 5 e 6 exibem os gráficos representativos das variações hormonais observadas em ambas as condições (CC e CR).

Descrição das curvas de secreção hormonal: as condições de chegada ao laboratório na CC e na CR são expressas pelos valores observados aos -30 minutos.

\subsection{1. АСТH}

Condição Controle (CC): seguindo o repouso de 30 minutos, a secreção do ACTH permanece constante, até o final dos procedimentos. O perfil de secreção revela um padrão ligeiramente ascendente, atingindo um máximo aos 75 minutos, representando um acréscimo de 19,17 \% em relação ao instante 0 . Nessa condição, a paciente se emocionou durante o repouso, com lembranças sobre fatos dos quais não se recordou posteriormente.

Condição de Recuperação (CR): o perfil de secreção do ACTH na curva da CR segue o observado na curva da $\mathrm{CC}$, num perfil ascendente em direção à vivência, com um ponto máximo atingido aos 60 minutos, o que representa um aumento de $15,3 \%$ em relação ao instante de 0 minuto, seguido por queda discreta pelas fases subseqüentes da técnica, em direção de valor observado no instante 0 , atingido aos 120 minutos. 


\section{TABELA II}

Resultados do sujeito 2 - dosagens hormonais, médias, desvios padrão, erros padrão, medianas e intervalos de confiança CC - condição controle CR - condição de recuperação
DP - desvio padrão
EP - erro padrão
IC - intervalo de confiança

Os cálculos estatísticos foram realizados utilizando-se os valores observados entre os instantes de 0 e 120 minutos.

\begin{tabular}{|c|c|c|c|c|c|c|c|c|c|c|c|c|}
\hline $\begin{array}{l}\text { Гempo } \\
\text { min }\end{array}$ & $\begin{array}{r}\text { ACTH-CC } \\
\mathrm{ng} / \mathrm{ml}\end{array}$ & $\begin{array}{r}\text { ACTH-CR } \\
\mathrm{ng} / \mathrm{ml}\end{array}$ & $\begin{array}{r}\text { ADR-CC } \\
\mathrm{pg} / \mathrm{ml}\end{array}$ & $\begin{array}{r}\text { ADR-CR } \\
\mathrm{pg} / \mathrm{ml}\end{array}$ & $\begin{array}{r}\text { CORT-CC } \\
\mathrm{ug} / \mathrm{dl}\end{array}$ & $\begin{array}{r}\text { CORT-CR } \\
\mathrm{ug} / \mathrm{dl}\end{array}$ & $\begin{array}{r}\text { PRL-CC } \\
\mathrm{ng} / \mathrm{ml}\end{array}$ & $\begin{array}{r}\text { PRL-CR } \\
\mathrm{ng} / \mathrm{ml}\end{array}$ & $\begin{array}{r}\text { TSH-CC } \\
\mathrm{uUI} / \mathrm{ml}\end{array}$ & $\begin{array}{r}\text { TSH-CR } \\
\mathrm{uUI} / \mathrm{ml}\end{array}$ & $\begin{array}{r}\mathrm{GH}-\mathrm{CC} \\
\mathrm{ng} / \mathrm{ml}\end{array}$ & $\begin{array}{r}\mathrm{GH}-\mathrm{CR} \\
\mathrm{ng} / \mathrm{ml}\end{array}$ \\
\hline-30 & 71,00 & 95,00 & 90,00 & 1,00 & 24,70 & 13,40 & 7,00 & 12,20 & 3,21 & 2,28 & 5,47 & \\
\hline 0 & 73,0 & 3,00 & 2,00 & 99, & 28,00 & & & 10,10 & 2,85 & 1,97 & & \\
\hline 15 & 76,00 & 98,00 & 87,00 & 102,00 & 23,60 & 10,90 & 4,80 & 8,70 & 2,70 & 1,85 & 13 & \\
\hline 30 & 80,00 & 102,00 & 112,00 & 95,00 & 23,10 & 9,90 & 4,60 & 90 & 2,57 & 1,80 & ,04 & \\
\hline 45 & & & & 7,00 & 0,70 & 9,10 & 4,80 & 40 & 2,36 & 1,72 & ,42 & \\
\hline 60 & & & & & & 8,0 & & & 2,10 &, 77 & 71 & \\
\hline 75 & & & 00 & & & 7,30 & 4,7 & & 2,00 &., 70 & 39 & \\
\hline 90 & 5,00 & 0,00 & 96,00 & 8,00 & 15,50 & 6,70 & 4,80 & 70 & 1,88 & .74 & ,29 & \\
\hline 105 & & 0 & & & & 7,80 & 4,70 & 00 & 1,85 & 1,66 & 29 & \\
\hline 120 & 83,00 & 98,00 & 100,00 & & ,20 & 9,30 & 4,50 & 90 & 1,89 & 1,72 & 25 & \\
\hline Tédia & 81,6670 & 103,0000 & 100,5600 & 112,0000 & 19,1670 & 8,9560 & 4,8110 & 7,2780 & 2,2450 & 1,7680 & 1,7360 & 2,800 \\
\hline DP & 4,5830 & 5,6350 & 9,3420 & 17,1320 & 5,0280 & 1,6511 & 0,2848 & 1,5070 & 0,3848 & 0,0935 & 1,8740 & 3,377 \\
\hline D & 280 & 3780 & 140 & 10 & 760 & 513 & & 024 & 283 & 0,0312 & 0,6247 & 1260 \\
\hline Ulat & 0000 & 102,0000 & 100,0000 & 104,0000 & 9000 & 9,1000 & 000 & 000 & 2,0980 & 1,7390 & 0,7100 & 0,36 \\
\hline$<95 \%$ & 78,1440 & 98,6690 & 93,3740 & 98,8310 & 15,3010 & 7,6840 & 4,5920 & 5,0300 & 1,9490 & 1,6960 & 0,2949 & 0,20 \\
\hline$>95 \%$ & 85,1890 & 107,3300 & 107,7400 & 125,1700 & 23,0320 & 10,2270 & 6,1190 & 8,4360 & 2,5410 & 1,8400 & 3,1760 & 5,39 \\
\hline
\end{tabular}


A

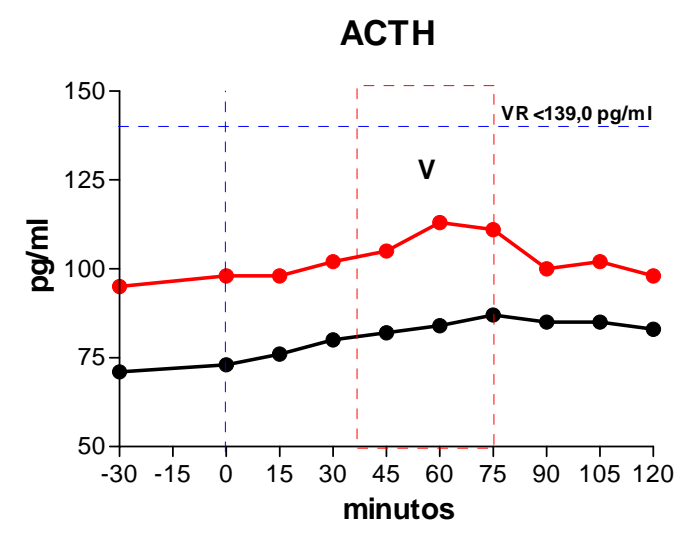

C

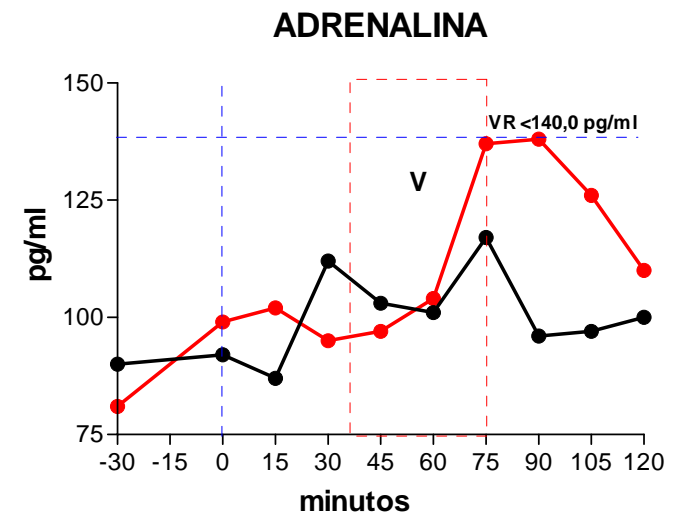

$\mathbf{E}$

TSH

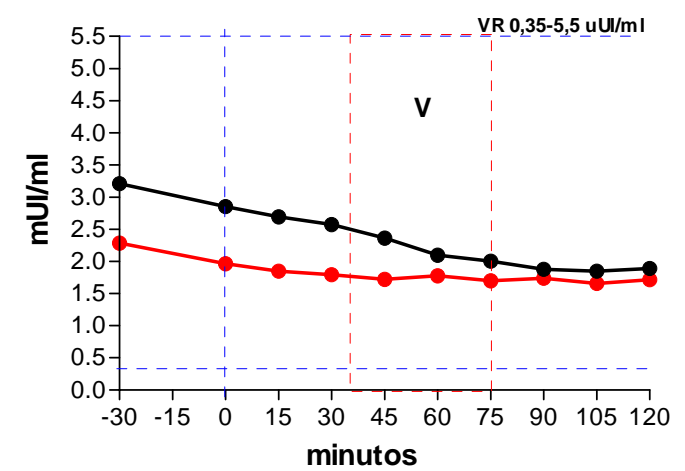

B

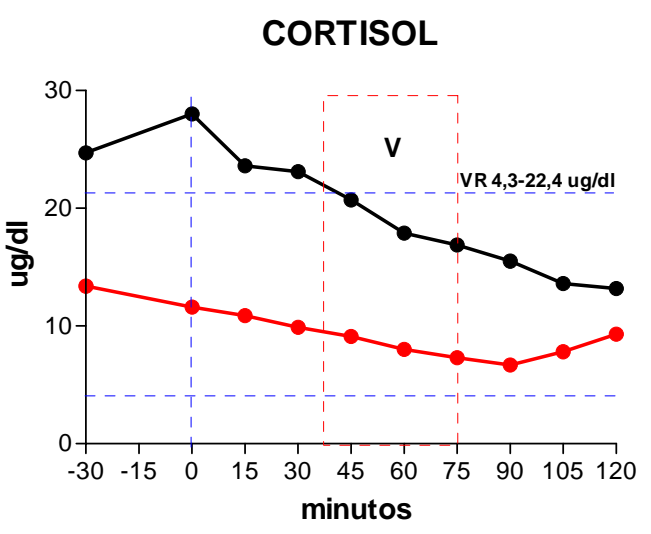

D

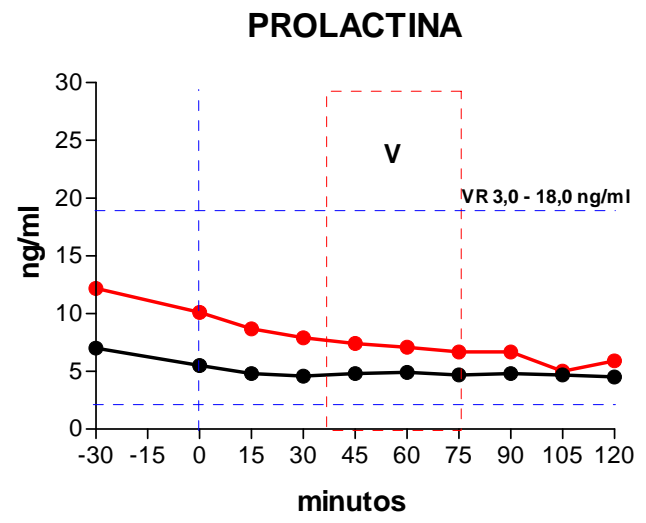

$\mathbf{F}$

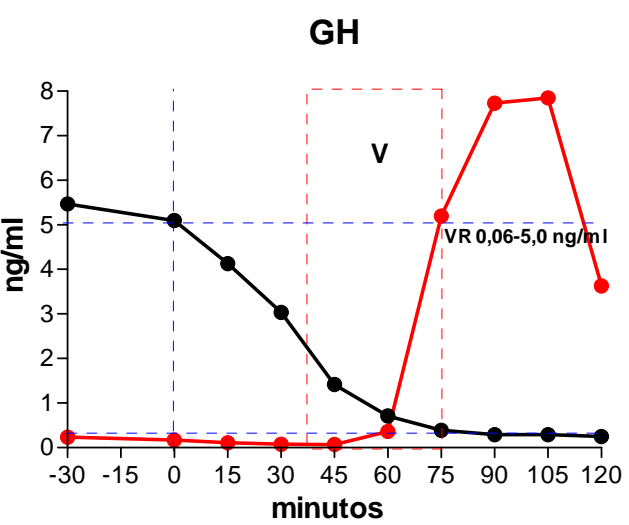

Figura 4 - curvas de tempo e resposta das variações hormonais do sujeito 2 submetido à recuperação de memórias traumáticas, .

$\bullet-\bullet$ - condição controle (CC).

$\bullet-\bullet$ - condição de recuperação (CR).

V - vivência.

VR - valores de referência para o ensaio 
A

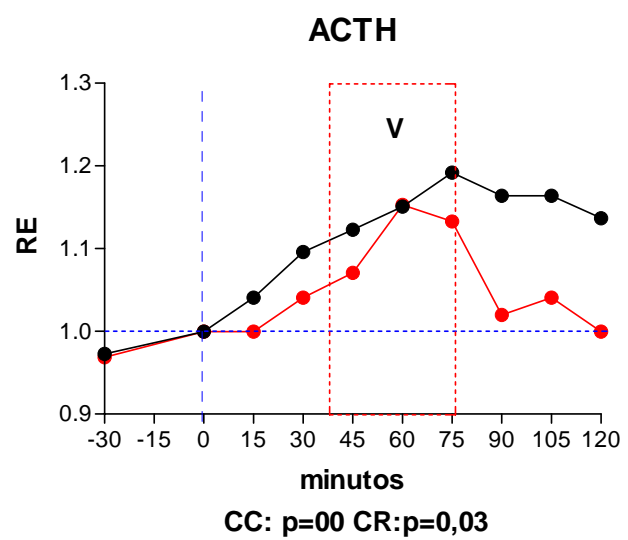

C

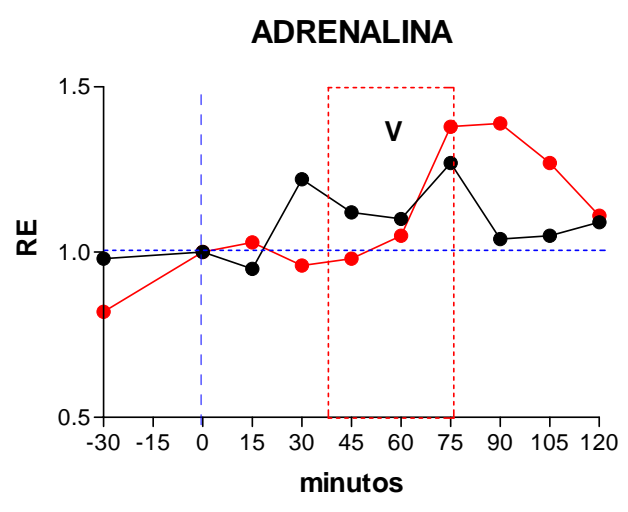

CC: $p=0,54$ CR: $p=0,01$

E

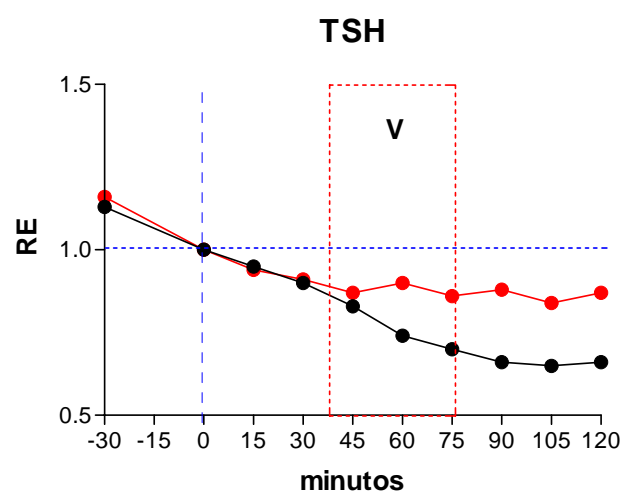

CC: $p=0,00$ CR: $p=0,01$
B

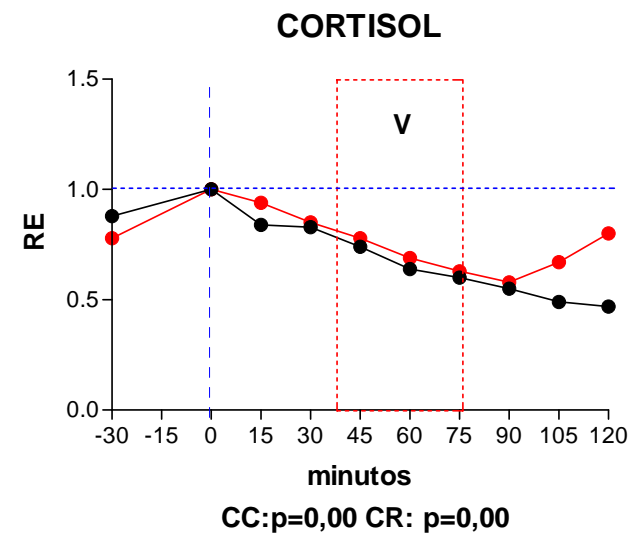

D

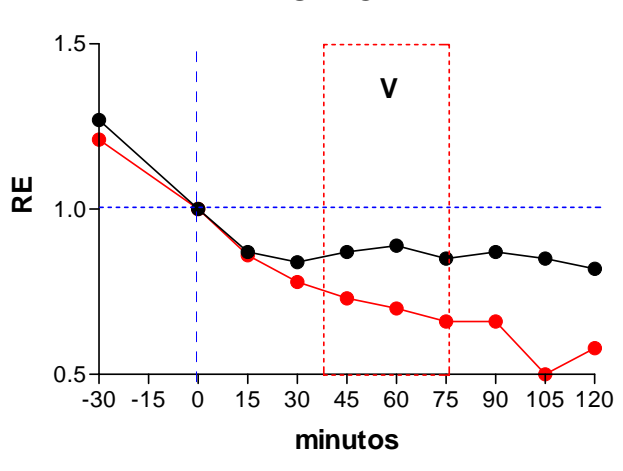

CC: $p=0,05$ CR: $p=0,00$

\section{$\mathbf{F}$}

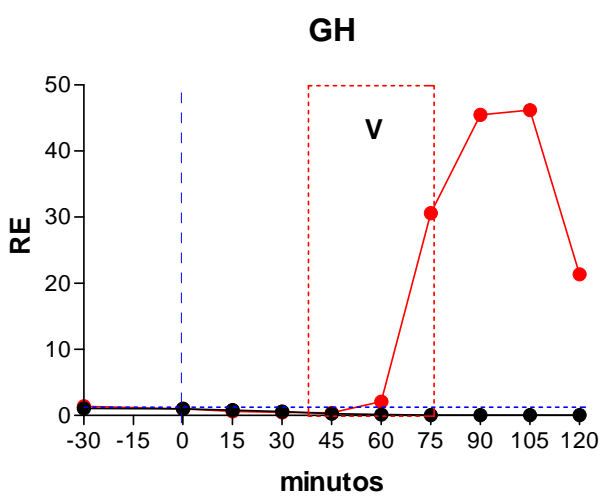

CC: $p=0,00$ CR: $p=0,01$

Figura 5 - curvas rescalonadas de tempo e resposta das variações hormonais do sujeito 2 submetido à recuperação de memórias traumáticas.

•-• - condição controle (CC).

$\bullet-\bullet$ - condição de recuperação (CR).

V - vivência. 
A

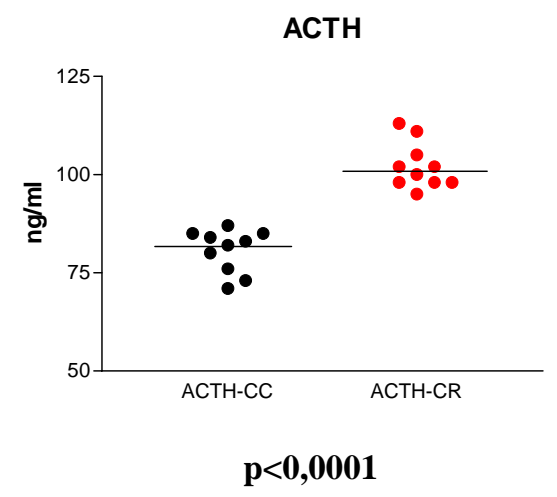

C

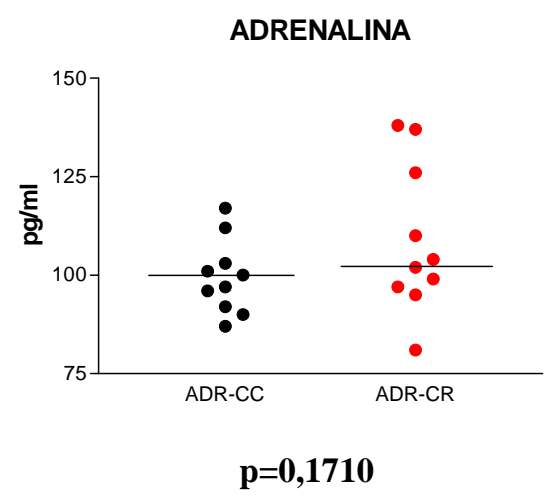

$\mathbf{E}$

TSH

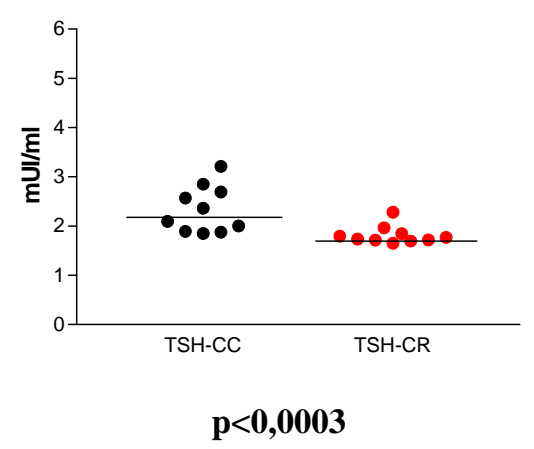

B

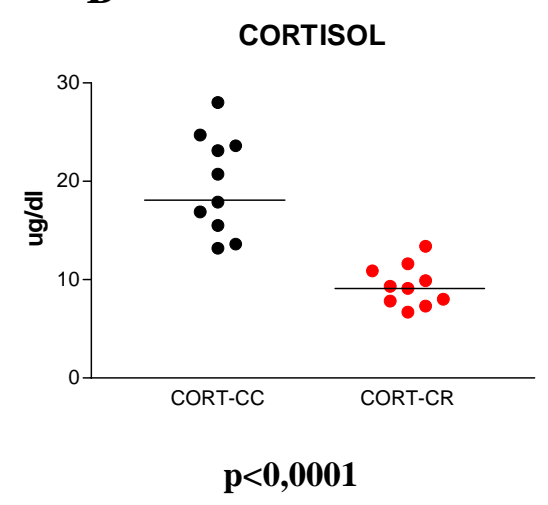

D

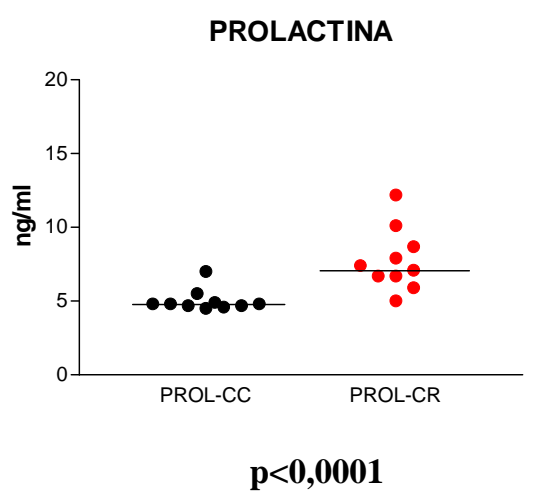

$\mathbf{F}$

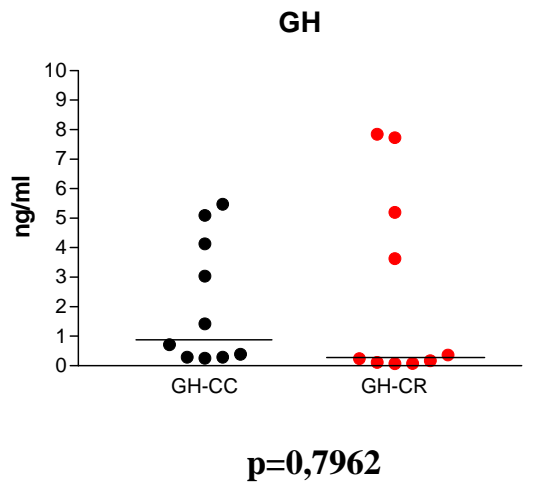

Figura 6 - variações hormonais em função do tempo do sujeito 2 submetido à recuperação de memórias traumáticas, expressas em medianas.

Mann-Whiney, $\mathrm{U}$ teste, $\mathrm{p}<0,005$.

$\bullet-\bullet$ - condição controle (CC).

$\bullet-\bullet$ - condição de recuperação (CR). 


\subsubsection{Cortisol}

Condição Controle (CC): entre os instantes -30 e 0 minuto, observa-se elevação de cerca de $16,3 \%$ na secreção hormonal. A partir desse instante, ocorre queda lenta e gradual do cortisol, até o valor mínimo observado aos 120 minutos, no final dos procedimentos, representando uma queda total, em relação ao instante 0 , de 52,85 \%.

Condição de Recuperação (CR): a partir do instante de chegada ao laboratório, os níveis de cortisol apresentam queda homogênea até atingir o valor mínimo observado aos 90 minutos, com uma queda total de 30,53 \% em relação ao instante 0 , quando, então, apresenta nova subida entre os 90 e os 120 minutos, de $38,80 \%$.

\subsubsection{Adrenalina}

Condição Controle (CC): observam-se duas elevações na secreção de adrenalina: entre os 15 minutos e os 30 minutos, de $28,73 \%$ e, entre os 60 e os 75 minutos, de 15,84\%, seguidos por queda rápida de $17,94 \%$, entre os 75 e os 90 minutos, seguida por estabilidade que se mantém até os 120 minutos.

Condição de Recuperação (CR): a condição de chegada ao laboratório é equivalente ao da CC. Segue-se uma elevação de secreção hormonal de $20,45 \%$ entre -30 e 0 minutos. A secreção hormonal permanece praticamente constante até os 45 minutos, quando, então, apresenta elevação significativa com um máximo atingido aos 90 minutos (aumento de 39,39 \%, em relação ao instante de 0 minuto, e de 45,26 \%, em relação ao instante de 30 minutos). Depois disso, ocorre queda lenta e progressiva de secreção, atingindo, aos 120 minutos, valores $11 \%$ mais elevados do que os do instante 0 .

\subsubsection{Prolactina}

Condição Controle (CC): entre o instante de chegada ao laboratório e o início dos procedimentos, observa-se queda de 10,9 \% na secreção da prolactina, quando então permanece constante, até o final dos procedimentos. 
Condição de Recuperação (CR): a curva representativa da secreção da prolactina segue o perfil observado na $\mathrm{CC}$, em valores discretamente mais elevados, com ambas as curvas se tocando aos 105 minutos, permanecendo estáveis até o final dos procedimentos, aos 120 minutos. Não se observou alteração significativa da secreção da prolactina a não ser a queda um pouco mais rápida entre os instantes de 90 e 105 minutos, quando as curvas se encontram.

\subsubsection{TSH}

Condição Controle (CC): a partir do instante de chegada ao laboratório, passando pelos 30 minutos de repouso, ocorre queda constante e homogênea da secreção do TSH, até atingir os valores mínimos observados aos 105 minutos, com queda, em relação ao instante de 0 minuto, de $33,6 \%$.

Condição de Recuperação (CR): a secreção do TSH segue o perfil de queda homogênea observado na $\mathrm{CC}$, com valores convergentes, até que ambas as curvas se tocam aos 90 minutos, permanecendo indistinguíveis até o final dos procedimentos. Não se observaram alterações da secreção do TSH nas diferentes fases dos procedimentos.

\subsubsection{GH}

Condição Controle (CC): após repouso de 30 minutos, a secreção do GH se reduz de uma maneira constante até se estabilizar aos 75 minutos e continuar caindo mais lentamente até atingir os valores mínimos observados aos 120 minutos, numa redução de 95,09 \% em relação ao instante 0 .

Condição de Recuperação (CR): após o repouso de 30 minutos, e atingindo seu valor mínimo aos 45 minutos, há uma queda de secreção hormonal constante de $58 \%$ em relação ao instante 0. A partir daí, observa-se um forte aumento da secreção de GH, subindo até os 90 minutos, quando, então, a subida se atenua, até atingir o pico máximo de secreção hormonal aos 105 minutos, num incremento de 4517,64 \%\% em relação ao instante 0 . Nos quinze 
minutos subseqüentes, até o final dos procedimentos, ocorre queda rápida da secreção do $\mathrm{GH}$, apresentando um declínio, em relação ao valor máximo atingido, de 53,57\% \%, mas ainda $2.035,29 \%$ maior do que os valores observados no instante 0 .

\section{Análise estatística}

Os resultados da análise estatística acham-se expressos no Quadro II.

4.3. SUJEITO 3 - RCM - sexo feminino, 46 anos. Diagnóstico pelo SCID/DSM-IV: não preencheu nenhum critério diagnóstico $-\mathrm{BDI}=0$. HAM-A 07. Tipo Matutino do GMDRB.

Resumo: instante 0: início do Relaxamento. 35 minutos: início do Aprofundamento. A partir dos 38 minutos: Recuperação, na qual ocorrem as vivências. 45 minutos aos 68 minutos: MMT. 78 minutos: identificação da Decisão e Redecisão. 85 minutos: inicia-se a Desprogramação. 98 minutos: inicia-se Programação Positiva. 105 minutos: início do Retorno e Finalização.

Resultados das dosagens hormonais: a Tabela III mostra os resultados das dosagens hormonais realizadas no sujeito 3 , em ambas as condições (CC e CR).

Gráficos representativos das dosagens hormonais: as figuras 7, 8 e 9 exibem os gráficos representativos das variações hormonais observadas em ambas as condições (CC e $\mathrm{CR})$.

Descrição das curvas de secreção hormonal: as condições de chegada ao laboratório na CC e na CR são expressas pelos valores observados aos -30 minutos.

\subsection{1. АCTH}

Condição controle (CC): o valor observado no instante de -30 minutos permanece constante durante o período de repouso, posteriormente subindo até os 30 minutos, com um incremento de $4,91 \%$ em relação ao instante 0 , seguido por uma pequena queda, entre os $30 \mathrm{e}$ os 45 minutos, de 7,47\%, quando, então, ocorre uma oscilação da secreção do ATCH: um 
QUADRO II - Sujeito 2 - valores de $\boldsymbol{p}$ : C-teste, Mann-Whitney ( U-teste), p<0,05

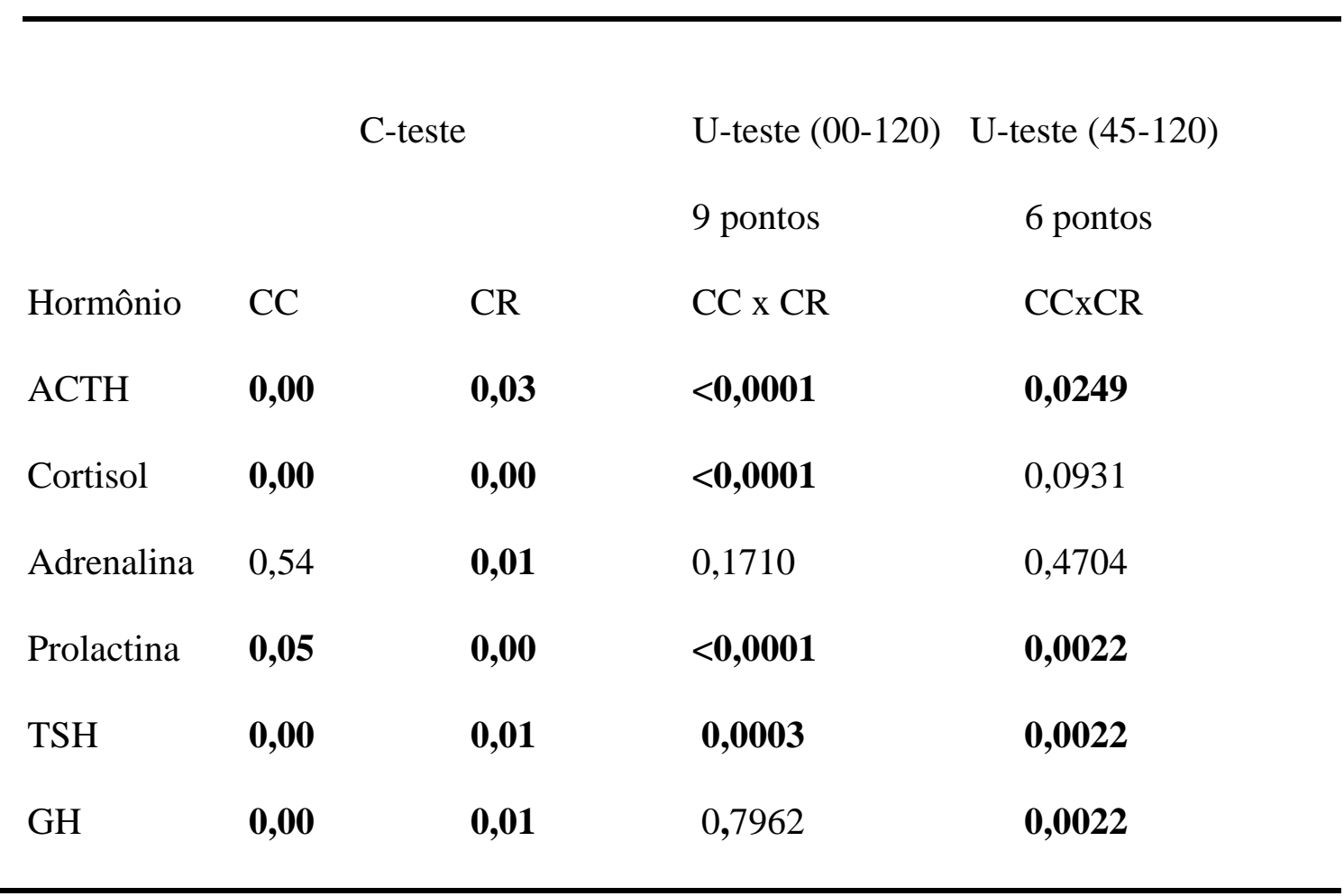

Em negrito, os resultados estatisticamente significativos.

00-120 - (minutos) intervalo de valores utilizados para a análise estatística 45-120 - (minutos) intervalo de valores utilizados para a análise estatística 


\section{TABELA III}

Resultados do sujeito 3 - dosagens hormonais, médias, desvios padrão, erros padrão, medianas e intervalos de confiança CC - condição controle CR - condição de recuperação

DP - desvio padrão

$$
\text { EP - erro padrão }
$$

IC - intervalo de confiança

Os cálculos estatísticos foram realizados utilizando-se os valores observados entre os instantes de 0 e 120 minutos

\begin{tabular}{|c|c|c|c|c|c|c|c|c|c|c|c|c|}
\hline $\begin{array}{l}\text { Tempo } \\
\text { min }\end{array}$ & $\begin{array}{c}\text { ACTH-CC } \\
\mathrm{pg} / \mathrm{ml}\end{array}$ & $\begin{array}{l}\text { ACTH-CR } \\
\mathrm{pg} / \mathrm{ml}\end{array}$ & $\begin{array}{c}\text { ADR-CC } \\
\mathrm{pg} / \mathrm{ml}\end{array}$ & $\begin{array}{c}\text { ADR-CR } \\
\mathrm{pg} / \mathrm{ml}\end{array}$ & $\begin{array}{c}\text { CORT-CC } \\
\text { ug/dl }\end{array}$ & $\begin{array}{c}\text { CORT-CR } \\
\text { ug/dl }\end{array}$ & $\begin{array}{c}\text { PRL-CC } \\
\text { ng/ml }\end{array}$ & $\begin{array}{c}\text { PRL-CR } \\
\mathrm{ng} / \mathrm{ml}\end{array}$ & $\begin{array}{l}\mathrm{TSH}-\mathrm{CC} \\
\mathrm{uUI} / \mathrm{ml}\end{array}$ & $\begin{array}{l}\text { TSH-CR } \\
\mathrm{uUI} / \mathrm{ml}\end{array}$ & $\begin{array}{l}\mathrm{GH}-\mathrm{CC} \\
\mathrm{ng} / \mathrm{ml}\end{array}$ & $\begin{array}{l}\mathrm{GH}-\mathrm{CR} \\
\mathrm{ng} / \mathrm{ml}\end{array}$ \\
\hline-30 & 98,00 & 92,00 & 88,00 & 72,00 & 15,20 & 16,70 & 8,40 & 13,80 & 1,856 & 1,975 & 0,16 & 0,32 \\
\hline 0 & 102,00 & 96,00 & 81,00 & 70,00 & 14,60 & 15,50 & 7,40 & 16,10 & 2,082 & 1,970 & 0,09 & 0,12 \\
\hline 15 & 5,00 & 0,00 & 108,00 & 95,00 & 14,00 & 12,80 & 90 & 13,10 & 65 & 40 & 0,07 & 09 \\
\hline 30 & $107, \mathrm{C}$ & 105,00 & 121,00 & 96,00 & 13,10 & 11,80 & 6,50 & 12,70 & 1,729 & 743 & 0,08 & 0,08 \\
\hline 45 & 99,00 & 98,00 & 133,00 & 107,00 & 11,70 & 11,50 & 5,30 & 10,10 & 1,793 & 1,746 & 0,10 & 0,06 \\
\hline 60 & 104,00 & 97,00 & 136,00 & 117,00 & 10,60 & 11,30 & 5,00 & 12,30 & 1,550 & 1,724 & 0,09 & 0,14 \\
\hline 75 & 7,00 & 100,00 & 124,00 & 130,00 & 8,90 & 10,00 & 4,70 & 12,00 & 1,728 & 20 & 0,11 & 7,28 \\
\hline 90 & 2,00 & 103,00 & 121,00 & 141,00 & 9,40 & 7,50 & 4,70 & 11,40 & 1,529 & 1,000 & 0,16 & 10,10 \\
\hline 105 & 0,00 & 8,00 & 111,00 & 133,00 & 7,50 & 5,90 & 4,90 & 9,80 & 1,558 & 1,666 & 0,30 & 7,96 \\
\hline 120 & 132,00 & 108,00 & 95,00 & 115,00 & 6,90 & 6,20 & 4,60 & 10,30 & 1,554 & 1,486 & 0,56 & 7,68 \\
\hline Tédia & 107,5600 & 96,8000 & 114,4400 & 111,5600 & 10,7440 & 10,2780 & 5,5560 & 11,9780 & 1,6880 & 1,6440 & 0,1733 & 3,7230 \\
\hline DP & 10,5960 & 9,5370 & 17,8050 & 22,2830 & 2,7940 & 3,2030 & 1,0770 & 1,9460 & 0,1765 & 0,2711 & 0,1614 & 4,3680 \\
\hline EP & 3,5320 & 3,1790 & 5,9350 & 7,4280 & 0,9314 & 1,0680 & 0,3591 & 0,6487 & 0,0588 & 0,0904 & 0,0538 & 1,4560 \\
\hline Mediana & 104,0000 & 93,6000 & 121,0000 & 115,0000 & 10,6000 & 11,3000 & 5,0000 & 12,0000 & 1,6650 & 1,7240 & 0,1000 & 0,1400 \\
\hline IC $<95 \%$ & 99,4410 & 89,4700 & 100,7600 & 94,4270 & 8,5970 & 12,8920 & 4,7280 & 10,4820 & 1,5520 & 1,4350 & 0,0493 & 0,3658 \\
\hline IC $>95 \%$ & 115,7000 & 104,1300 & 128,1300 & 128,6800 & 7,8160 & 12,7400 & 6,3840 & 13,4740 & 1,8230 & 1,8520 & 0,2974 & 7,0810 \\
\hline
\end{tabular}


A

\section{АCTH}

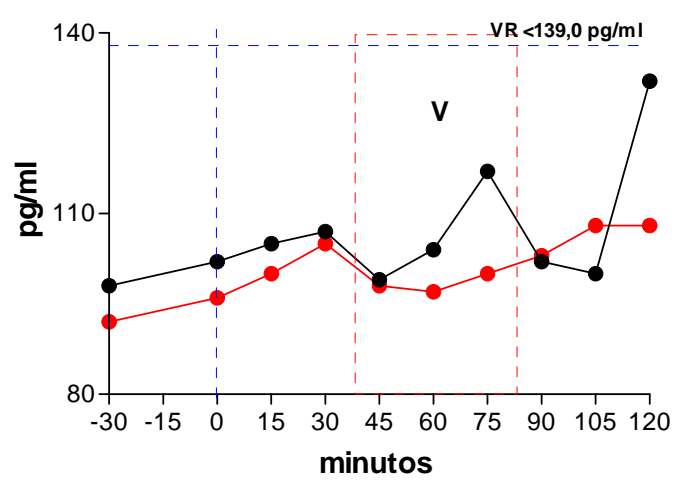

C

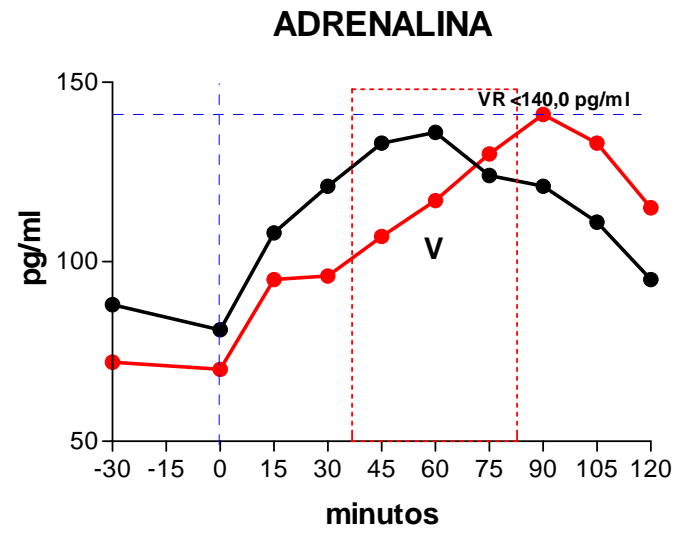

$\mathbf{E}$

TSH

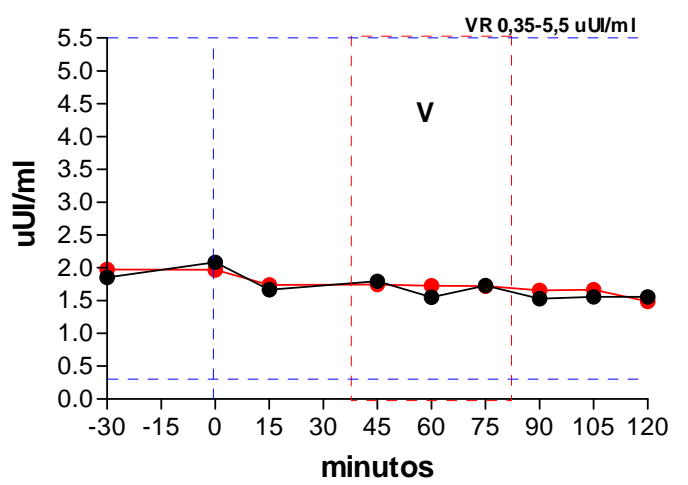

B

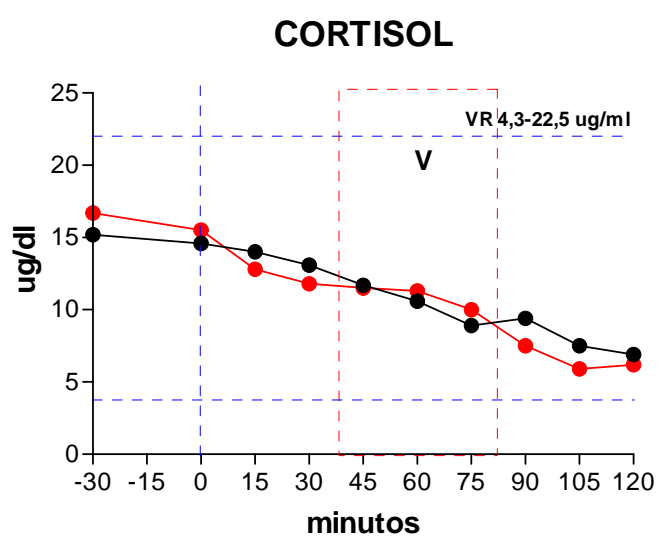

D

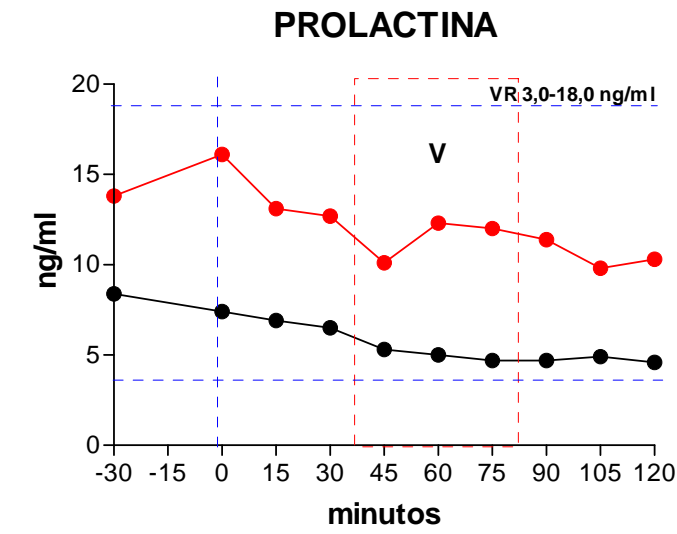

$\mathbf{F}$

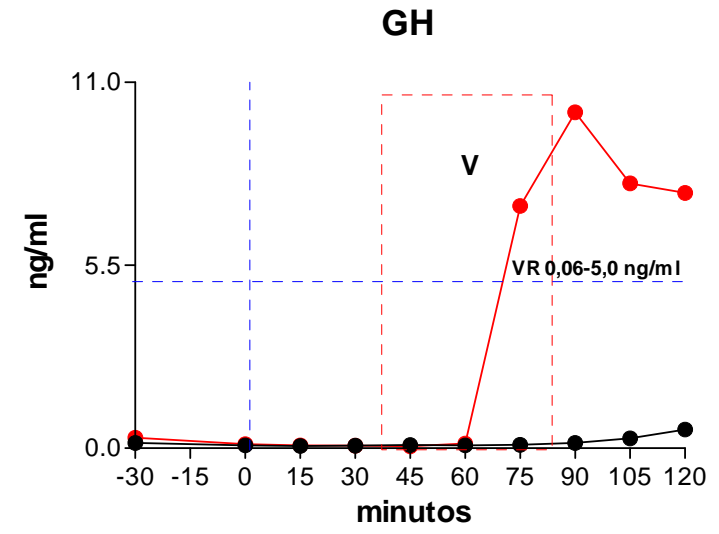

Figura 7 - curvas de tempo e resposta das variações hormonais do sujeito 3 submetido à recuperação de memórias traumáticas, .

$\bullet-\bullet$ - condição controle (CC).

$\bullet-\bullet$ - condição de recuperação (CR).

V - vivência.

VR - valores de referência para o ensaio 
A

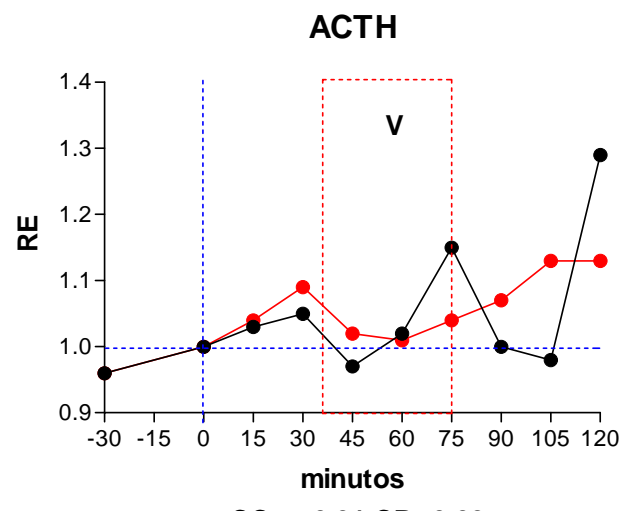

CC: $p=0,31$ CR: 0,02

C

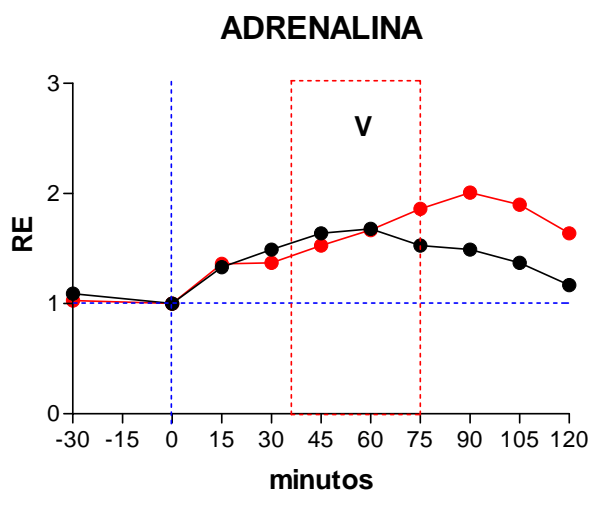

CC: $p=0,01$ CR: $P=0,00$

$\mathbf{E}$

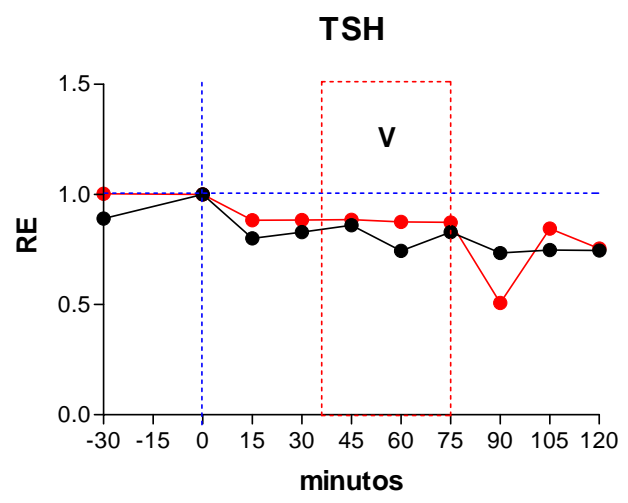

CC: $p=0,10$ CR: $p=0,36$
B

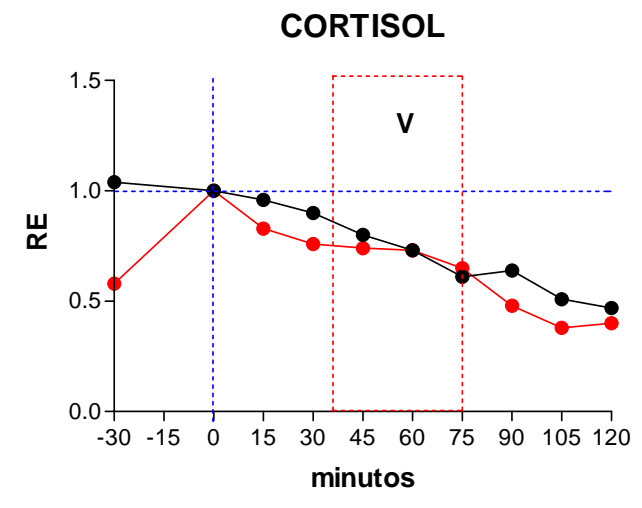

CC: $p=0,00$ CR $p=0,00$

D

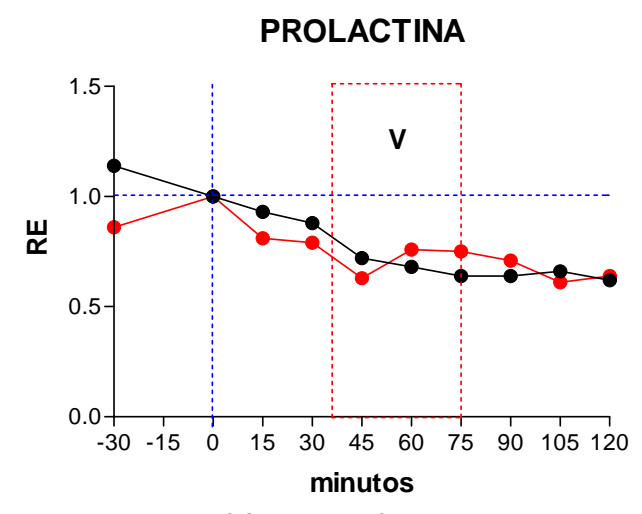

$\mathbf{F}$

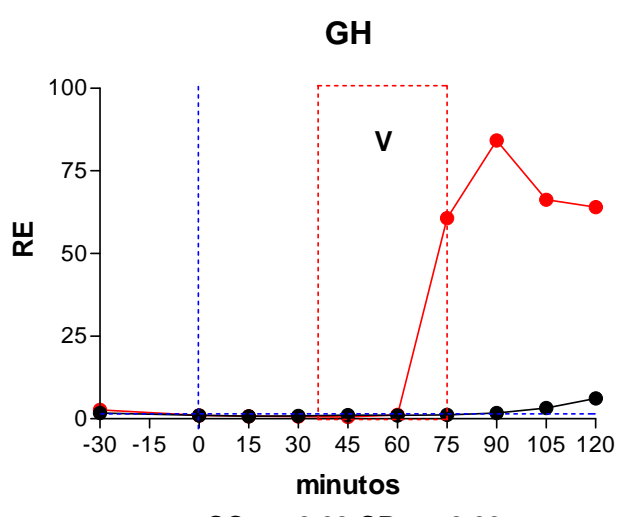

CC: $p=0,00$ CR: $p=0,00$

Figura 8 - curvas rescalonadas de tempo e resposta das variações hormonais do sujeito 3 submetido à recuperação de memórias traumáticas.

$\bullet-\bullet$ - condição controle (CC).

$\bullet-\bullet$ - condição de recuperação (CR).

V - vivência. 
A

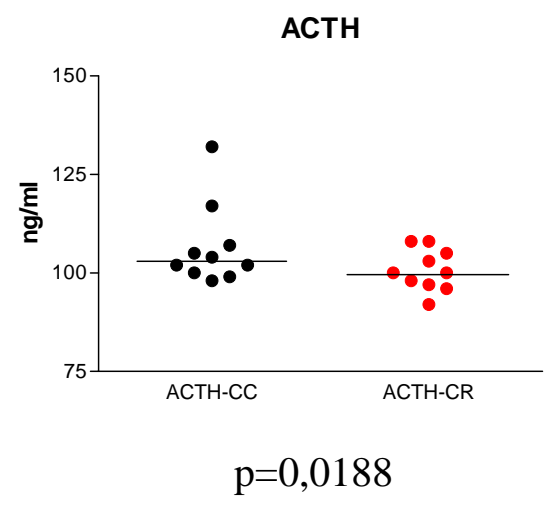

C

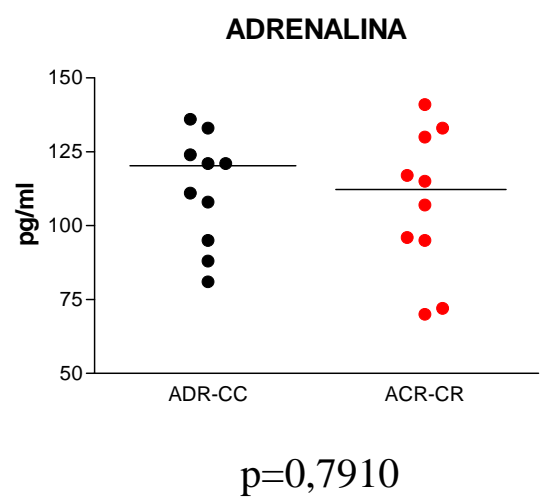

$\mathbf{E}$

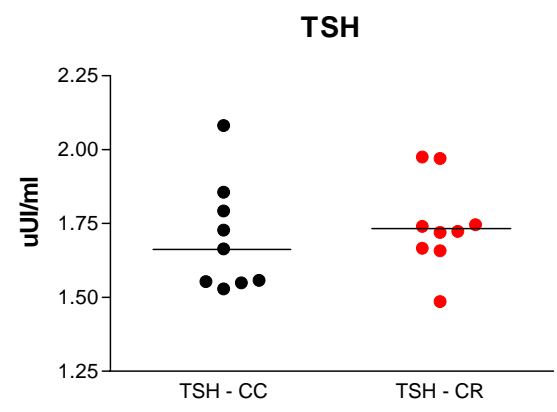

$\mathrm{p}=0,7962$
B

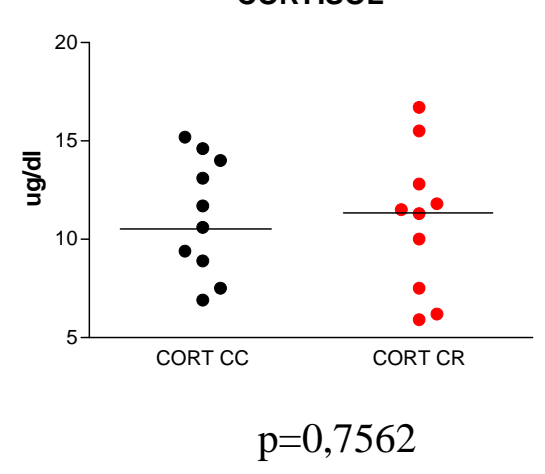

D

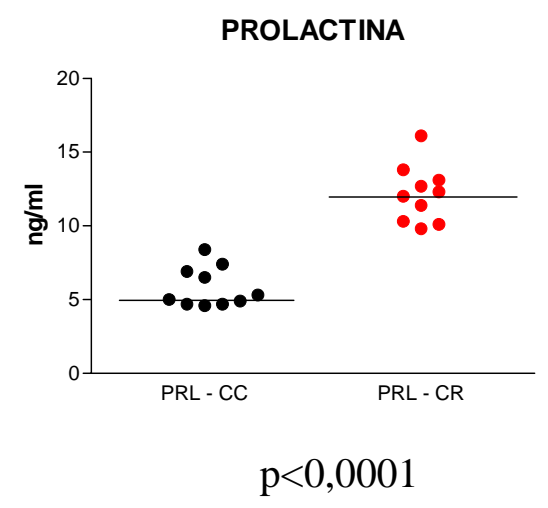

$\mathbf{F}$

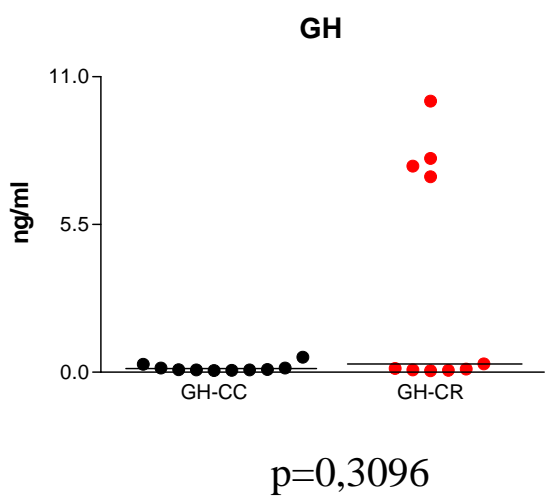

Figura 9 - variações hormonais em função do tempo do sujeito 3 submetido à recuperação de memórias traumáticas, expressas em medianas. Mann-Whiney, U teste, $\mathrm{p}<0,005$.

$\bullet$-• - condição controle (CC).

•-• - condição de recuperação (CR). 
incremento de $30 \%$ na sua secreção entre 45 e 75 minutos, seguido por um decréscimo de $14,0 \%$, entre 75 e 105 minutos, seguido por novo acréscimo de 32\% entre 105 e 120 minutos, momento final dos procedimentos. Entre 0 e 120 minutos observa-se um incremento de 29,41 $\%$ na secreção do ACTH.

Condição de Recuperação (CR): os valores relativos à CR praticamente se superpõem aos da CC: entre 0 e 30 minutos, um incremento de 9,37\%, seguido por uma queda, entre 30 e 60 minutos, de 7,61\%, seguido por uma ascensão até os 105 minutos, de $11,34 \%$, que se mantém constante até o final dos procedimentos. Entre 0 e 120 minutos, observa-se um acréscimo de $12,5 \%$ na secreção de ACTH.

\subsubsection{Cortisol}

Condição Controle (CC) e Condição de Recuperação (CR): a condição de chegada no laboratório é praticamente a mesma em ambas as condições. Após o repouso de 30 minutos, tais valores não se alteram. Ambas as curvas, a partir do instante 0 , correm paralelamente, em queda constante e homogênea, atingindo valores mínimos no fim dos procedimentos, com uma queda entre 0 e 120 minutos de aproximadamente $53,00 \%$.

\subsubsection{Adrenalina}

Condição Controle (CC): a secreção de adrenalina não se altera durante o repouso de trinta minutos. A partir do instante 0 , observa-se um aumento da secreção de adrenalina, que atinge o seu valor máximo aos 60 minutos, o que representa um aumento de $67,9 \% \mathrm{em}$ relação ao instante 0 . Entre os 30 e os 60 minutos, observa-se um acréscimo de 12,39 \%. Então, a secreção de adrenalina se reduz de maneira homogênea, atingindo seu mínimo aos 120 minutos, com uma queda de 33,82 \% em relação ao valor máximo observado aos 60 minutos e de $18,51 \%$ acima ao valor observado no instante 0 e $7,95 \%$ acima do valor de chegada ao laboratório. 
Condição de Recuperação (CR): a condição de chegada ao laboratório é 22,22 \% inferior ao valor observado na CC. Essa característica se mantém até os 15 minutos, quando a secreção hormonal na CR sobe menos rapidamente, mas atinge valores equivalentes ao pico dos 60 minutos observado na $\mathrm{CC}$, e chega a um máximo, aos 90 minutos, o que representa um incremento de $101,42 \%$ em relação ao instante 0 . Entre os 30 e os 90 minutos, há um incremento de 46,87 \% na secreção hormonal. A partir daí, a curva da CR segue o padrão representado pela curva da $\mathrm{CC}$, atingindo, aos 120 minutos, um valor $64,28 \%$ acima do observado no instante 0 .

\subsubsection{Prolactina}

Condição controle (CC): após o repouso de 30 minutos, observa-se redução de 11,8 \% e, a partir desse instante, uma redução progressiva da secreção de prolactina,, atingindo valores mínimos aos 75 minutos, o que representa queda de $36,48 \%$ em relação ao instante 0 , permanecendo constante até o final dos procedimentos.

Condição de Recuperação (CR): após repouso de 30 minutos, observa-se discreto aumento da secreção hormonal, o que representa uma elevação de 16,6 \% em relação ao instante de -30 minutos. A partir daí, a secreção de prolactina se reduz progressivamente atingindo o valor mínimo observado, aos 45 minutos, o que representa uma queda de 37,26\% em relação ao instante 0 . Entre os instantes de 45 minutos e 60 minutos, ocorre uma elevação da secreção hormonal em 27,78 \%, dentro da vivência, seguida por uma discreta queda até os 105 minutos permanecendo constante até o final dos procedimentos.

\subsubsection{TSH}

Condição Controle (CC): após o repouso de 30 minutos, há uma elevação de 12,17 \% na secreção do TSH. A partir do instante 0 observa-se um perfil oscilante de redução da secreção do TSH, com picos e depressões a cada 15 minutos (primeiro pico entre os 15 e os 45 minutos, com acréscimo de 7,68\% e o segundo pico entre os 60 e os 75 minutos, com 
acréscimo de $11.48 \%$ ), até que atinge o valor mínimo observado no final dos procedimentos, o que representa uma queda de $60,8 \%$ em relação ao instante 0 .

Condição de Recuperação (CR): após o repouso de 30 minutos, ocorre a mesma queda de secreção de TSH, no entanto sem o mesmo perfil de picos e depressões observados na CC. No instante dos 60 minutos (durante a fase de vivência), registra-se um afastamento de ambas as curvas (depressão da CC e constância da CR), seguido por queda comparável, até o final dos procedimentos, aos 120 minutos, quando os valores se equivalem. Entre os instantes 0 e 120 minutos, a queda total observada é de $24,56 \%$, sendo que $13,6 \%$ se dão entre os 75 e os 120 minutos.

\subsubsection{GH}

Condição Controle (CC): após o repouso de trinta minutos, a secreção do GH se reduz de maneira homogênea e permanece constante até o final dos procedimentos aos 120 minutos, com uma elevação de cerca de três vezes e meia do segmento final da curva de secreção entre os 75 e os 120 minutos

Condição de Recuperação (CR): a curva da CR segue indistinguível da curva da CC até os 60 minutos, quando, então, a secreção do $\mathrm{GH}$ aumenta de maneira intensa, atingindo um pico aos 90 minutos, o que representa um aumento de $8316 \%$ em relação ao início dos procedimentos (instante 0 ).

A seguir, apresenta uma discreta redução de 21,8 \% em relação ao valor dos 90 minutos, permanecendo constante até o final dos procedimentos, aos 120 minutos.

\section{Análise estatística}

Os resultados da análise estatística acham-se expressos no Quadro III.

4.4. SUJEITO 4 - RSJ - sexo masculino, 25 anos. Diagnóstico pelo SCID/DSM-IV: não preencheu nenhum critério diagnóstico - BDI $=3$. HAM-A 0. Tipo Matutino do GMDRB. 
QUADRO III - Sujeito 3 - valores de $\boldsymbol{p}$ : C-teste, Mann-Whitney (U-teste), p<0,05

\begin{tabular}{|c|c|c|}
\hline C-teste & U-teste (00-120) & U-teste (45-120) \\
\hline & 9 pontos & 6 pontos \\
\hline
\end{tabular}

\begin{tabular}{lcccc} 
Hormônio & CC & CR & CC x CR & CCxCR \\
ACTH & 0,31 & $\mathbf{0 , 0 2}$ & $\mathbf{0 . 0 1 8 8}$ & 0,5215 \\
Cortisol & $\mathbf{0 , 0 0}$ & $\mathbf{0 , 0 0}$ & 0,7572 & 0,6307 \\
Adrenalina & $\mathbf{0 , 0 1}$ & $\mathbf{0 , 0 0}$ & 0,7910 & $\mathbf{0 , 0 4 5 0}$ \\
Prolactina & $\mathbf{0 , 0 0}$ & $\mathbf{0 , 0 2}$ & $<\mathbf{0 , 0 0 0 1}$ & 0,8099 \\
TSH & 0,10 & 0,36 & 0,7962 & 0,1797 \\
GH & $\mathbf{0 , 0 0}$ & $\mathbf{0 , 0 0}$ & 0,3096 & 0,2403 \\
\hline
\end{tabular}

Em negrito, os resultados estatisticamente significativos.

00-120 - (minutos) intervalo de valores utilizados para a análise estatística 45-120 - (minutos) intervalo de valores utilizados para a análise estatística 


\section{TABELA IV}

Resultados do sujeito 4 - dosagens hormonais, médias, desvios padrão, erros padrão, medianas e intervalos de confiança CC - condição controle CR - condição de recuperação

DP - desvio padrão EP - erro padrão IC - intervalo de confiança

Os cálculos estatísticos foram realizados utilizando-se os valores observados entre os instantes de 0 e 120 minutos

\begin{tabular}{|c|c|c|c|c|c|c|c|c|c|c|c|c|}
\hline $\begin{array}{l}\text { Tempo } \\
\text { min }\end{array}$ & $\begin{array}{r}\text { ACTH-CC } \\
\mathrm{pg} / \mathrm{ml}\end{array}$ & $\begin{array}{r}\text { ACTH-CR } \\
\mathrm{pg} / \mathrm{ml}\end{array}$ & $\begin{array}{r}\text { ADR-CC } \\
\mathrm{pg} / \mathrm{ml}\end{array}$ & $\begin{array}{r}\text { ADR-CR } \\
\mathrm{pg} / \mathrm{ml}\end{array}$ & $\begin{array}{r}\text { CORT-CC } \\
\text { ug/dl }\end{array}$ & $\begin{array}{r}\text { ORT-CR } \\
\text { ug/dl }\end{array}$ & $\begin{array}{r}\text { PRL-CC } \\
\mathrm{ng} / \mathrm{ml}\end{array}$ & $\begin{array}{r}\text { PRL-CR } \\
\mathrm{ng} / \mathrm{ml}\end{array}$ & $\begin{array}{l}\text { TSH-CC } \\
\text { uUI/ml }\end{array}$ & $\begin{array}{r}\text { TSH-CR } \\
\mathrm{uUl} / \mathrm{ml}\end{array}$ & $\begin{array}{r}\mathrm{GH}-\mathrm{CC} \\
\mathrm{ng} / \mathrm{ml}\end{array}$ & $\begin{array}{r}\text { GH-CR } \\
\mathrm{ng} / \mathrm{ml}\end{array}$ \\
\hline-30 & 117,00 & 96,00 & 55,00 & 122,00 & 7,00 & 13,50 & 11,40 & 14,20 & 0,87 & 1,00 & 0,05 & 0,56 \\
\hline 0 & 98,00 & 98,00 & 63,00 & 76,00 & 4,70 & 13,00 & 9,70 & 13,60 & 0,71 & 0,99 & 0,05 & \\
\hline 15 & 92,00 & 95,00 & 73,00 & 68,00 & 3,90 & 12,80 & 8,00 & 13,00 & 0,68 & 0,90 & 0,05 & \\
\hline 30 & 90,00 & 92,00 & 74,00 & 71,00 & 3,90 & 12,60 & 7,60 & 12,80 & 0,66 & 0,91 & 0,05 & \\
\hline 45 & 86,00 & 92,00 & 96,00 & 92,00 & 3,80 & 12,90 & 7,40 & 12,70 & 0,57 & 0,89 & 0,05 & 43 \\
\hline 60 & 85,00 & 90,00 & 91,00 & 77,00 & 3,50 & 12,50 & 7,70 & 13,20 & 0,62 & 0,81 & 0,05 & ,42 \\
\hline 75 & 88,00 & 88,00 & 90,00 & 81,00 & 5,40 & 11,70 & 7,90 & 13,70 & 0,60 & 0,83 & 0,05 & 0,42 \\
\hline 90 & 85,00 & 87,00 & 76,00 & 90,00 & 4,00 & 10,30 & 8,00 & 11,80 & 0,54 & 0,90 & 0,05 & 0,40 \\
\hline 105 & 89,00 & 85,00 & 100,00 & 134,00 & 4,10 & 10,00 & 8,20 & 11,70 & 0,69 & 0,88 & 0,05 & ,38 \\
\hline 120 & 88,00 & 83,00 & 98,00 & 85,00 & 6,20 & 10,00 & 8,30 & 10,80 & 0,52 & 0,79 & 0,08 & , 37 \\
\hline Média & 89,0000 & 90,0000 & 84,5560 & 86,0000 & 4,3890 & 11,7560 & 8,0890 & 12,5890 & 0,6211 & 0,8827 & 0,0533 & 0,4411 \\
\hline DP & 4,0930 & 4,7960 & 13,2490 & 19,7230 & 0,8838 & 1,2990 & 0,6679 & 0,9662 & 0,0685 & 0,0604 & 0,0100 & 0,0603 \\
\hline EP & 1,3640 & 1,5990 & 4,4160 & 6,5740 & 0,2946 & 0,4330 & 0,2226 & 0,3221 & 0,0228 & 0,0201 & 0,0033 & 0,0201 \\
\hline Mediana & 88,0000 & 90,0000 & 90,0000 & 81,0000 & 4,0000 & 12,5000 & 8,0000 & 12,8000 & 0,6200 & 0,8900 & 0,0500 & 0,4200 \\
\hline IC $<95 \%$ & 85,8540 & 86,3140 & 74,3720 & 70,8400 & 3,7100 & 10,7570 & 7,5750 & 11,8460 & 0,5685 & 0,8363 & 0,0457 & 0,3948 \\
\hline IC>95\% & 92,1460 & 93,6860 & 94,7390 & 101,1600 & 5,0680 & 12,7540 & 8,6020 & 13,3320 & 0,6737 & 0,9291 & 0,0610 & 0,48 \\
\hline
\end{tabular}


A

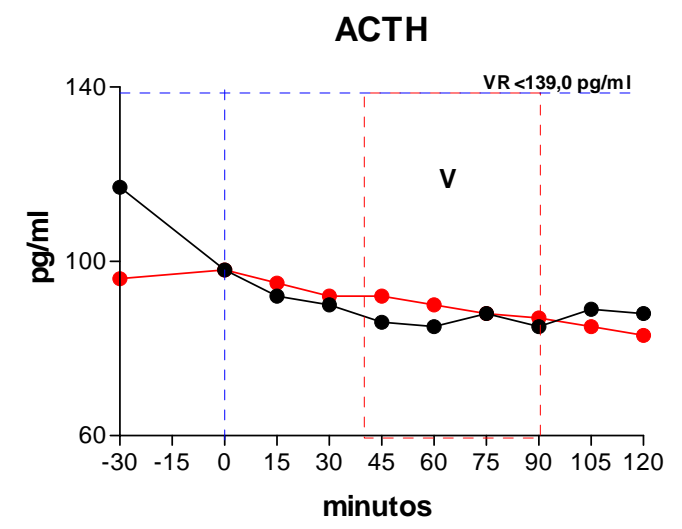

C

ADRENALINA

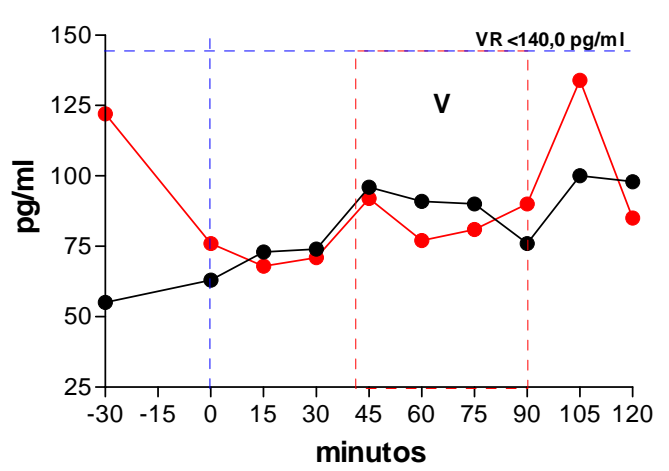

$\mathbf{E}$

TSH

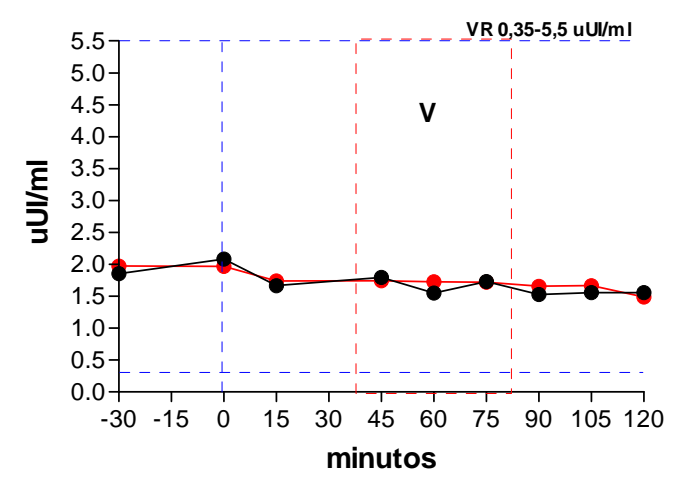

B

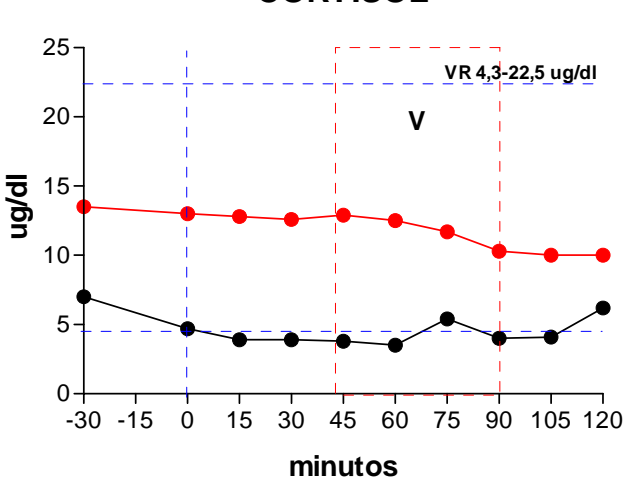

D

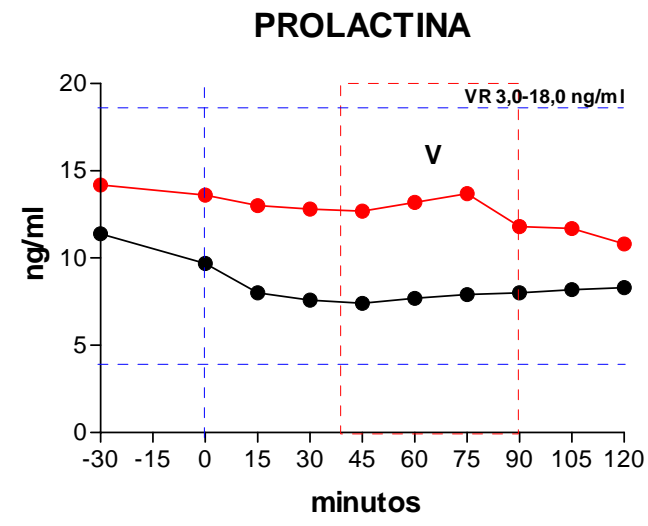

$\mathbf{F}$

GH

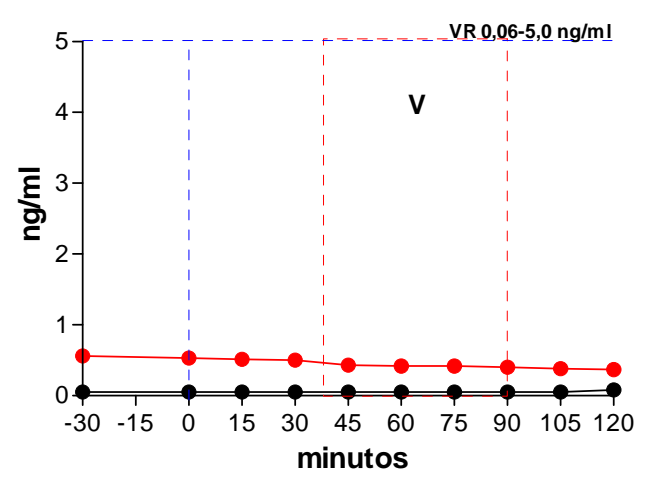

Figura 10 - curvas de tempo e resposta das variações hormonais do sujeito 4 submetido à recuperação de memórias traumáticas, .

$\bullet-\bullet$ - condição controle (CC).

$\bullet-\bullet$ - condição de recuperação (CR).

V - vivência.

VR - valores de referência para o ensaio 
A

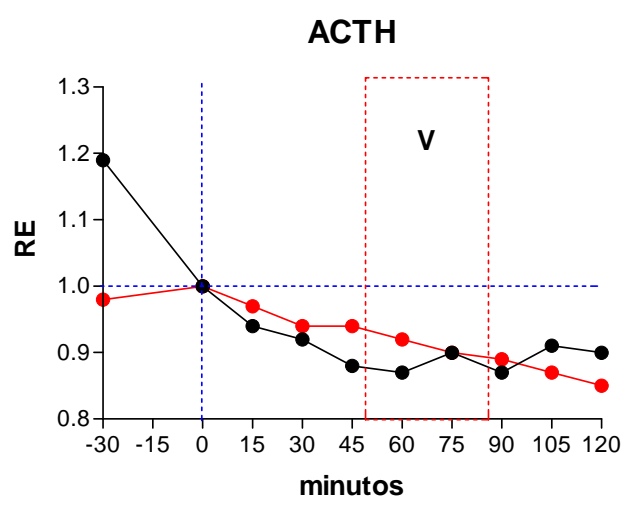

CC: $p=0,00$ CR: $p=0,00$

C

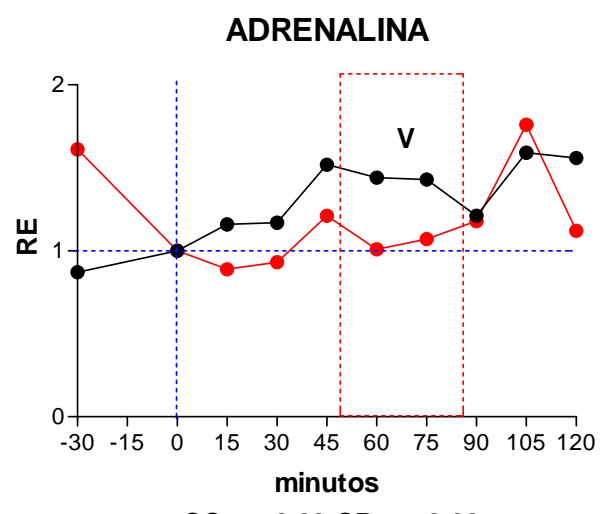

CC: $p=0,03$ CR: $p=0,28$

E

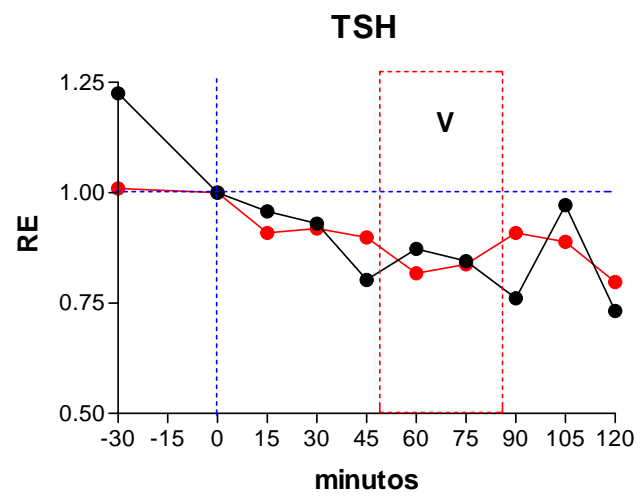

CC: $p=0,36$ CR: 0,04
B

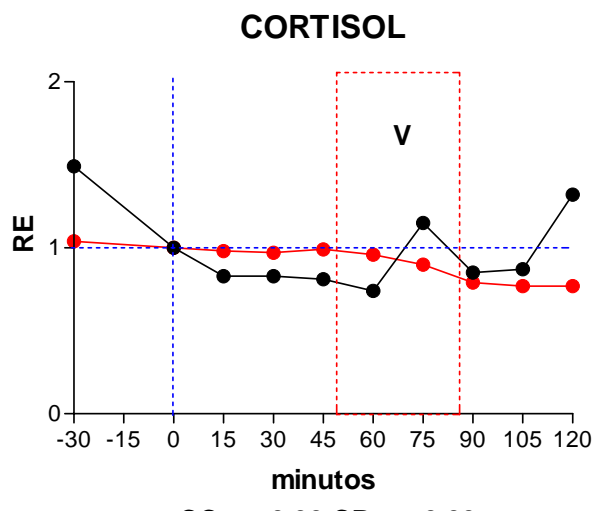

CC: $p=0,32$ CR: $p=0.00$

D

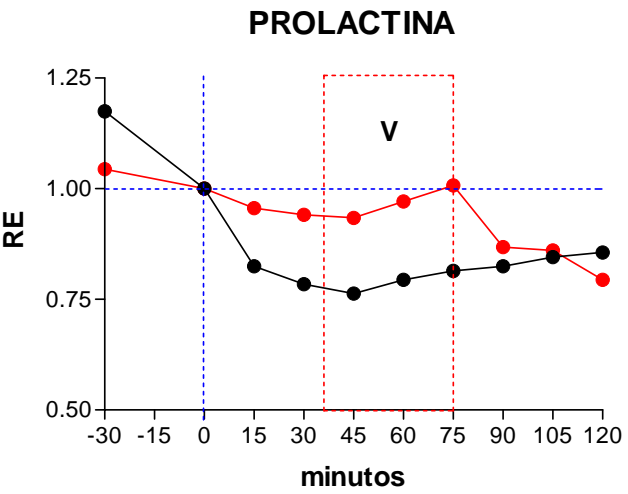

CC: $p=0,03$ CR: $p=0,02$

F

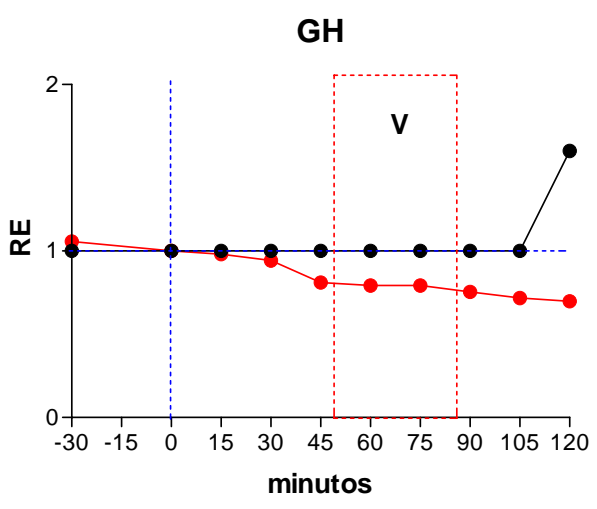

CC: $p=0,69$ CR: $p=0,00$

Figura 11 - curvas rescalonadas de tempo e resposta das variações hormonais do sujeito 4 submetido à recuperação de memórias traumáticas.

$\bullet-\bullet$ - condição controle (CC).

$\bullet-\bullet$ - condição de recuperação (CR).

V - vivência. 
A

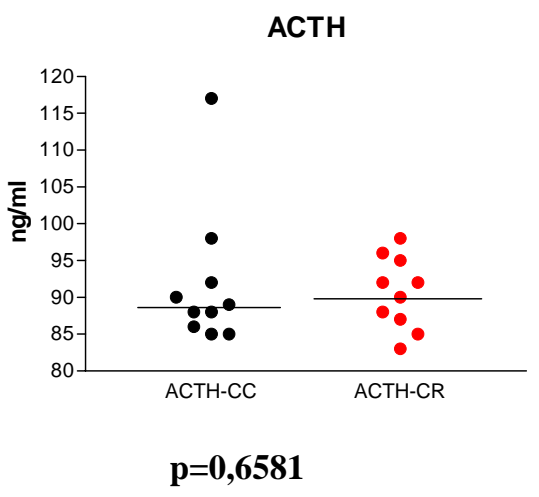

C

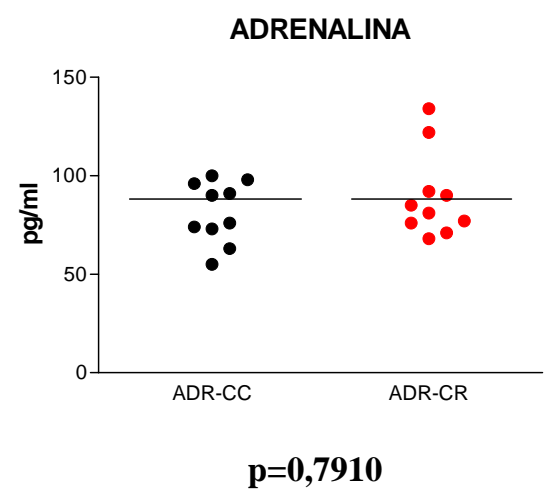

$\mathbf{E}$

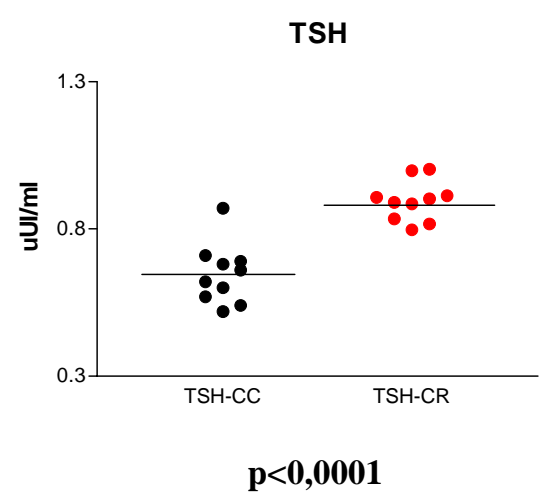

B

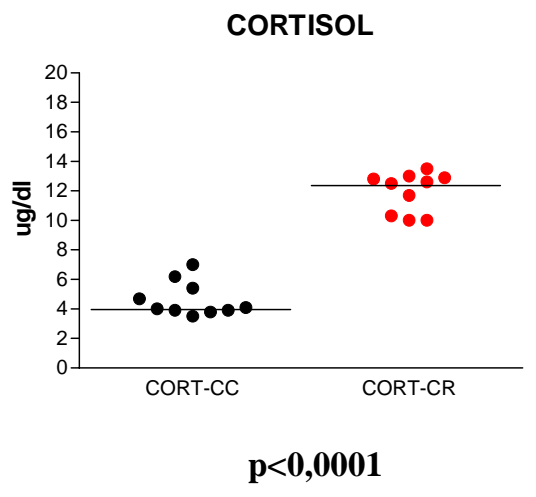

D

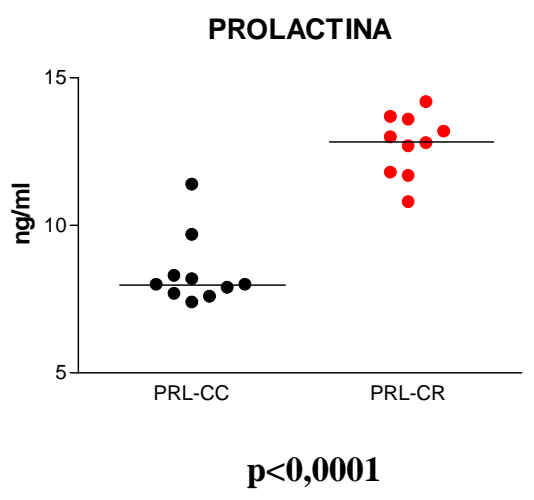

$\mathbf{F}$

GH

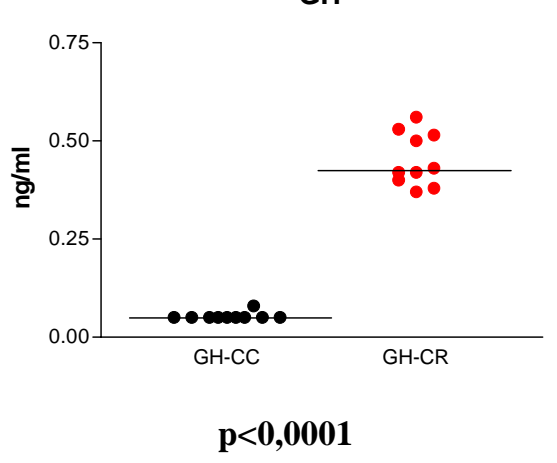

Figura 12 - variações hormonais em função do tempo do sujeito 4 submetido à recuperação de memórias traumáticas, expressas em medianas. Mann-Whiney, U teste, $\mathrm{p}<0,005$.

$\bullet-\bullet$ - condição controle (CC).

$\bullet-\bullet$ - condição de recuperação (CR). 
Resumo: instante 0: início do Relaxamento. 41 minutos: início do Aprofundamento. 49 minutos: fim do aprofundamento (o sujeito dormiu). A partir dos 50 minutos: Recuperação, quando ocorrem as vivências. Dos 50 minutos aos 85 minutos: MMT. Dos 85 aos 90 minutos: Decisão e Redecisão. Aos 100 minutos: inicia-se a Desprogramação. 110 minutos: Programação Positiva. 115 minutos: início do Retorno e Finalização.

Observações: as vivências foram experimentadas com forte conteúdo emocional referido pelo sujeito. Durante a $\mathrm{CR}$, não se observou agitação psicomotora, tendo o sujeito permanecido em repouso. O sujeito referiu sentir fome durante a vivência. No fim dos procedimentos, o sujeito se sentia bem, orientado no espaço e no tempo, com bom contacto com o ambiente. Foi submetido a acompanhamento psicoterápico subseqüente.

Resultados das dosagens hormonais: a Tabela IV mostra os resultados das dosagens hormonais realizadas no sujeito 4, em ambas as condições (CC e CR).

Gráficos representativos das dosagens hormonais: as figuras 10,11, e 12 exibem os gráficos representativos das variações hormonais observadas em ambas as condições (CC e CR).

Descrição das curvas de secreção hormonal: as condições de chegada ao laboratório na CC e na CR são expressas pelos valores observados aos -30 minutos.

\subsection{1. АСТН}

Condição controle (CC) e Condição de recuperação (CR): os valores referentes à CR são mais elevados dos que os da $\mathrm{CC}$, no instante de chegada ao laboratório. Após repouso de 30 minutos, ambas as curvas se igualam e seguem juntas, em estabilidade, até o final dos procedimentos. A queda total de secreção do ACTH na curva da CC, entre os instantes de 0 a 120 minutos, é de 10,20 \%. A queda total de secreção do ACTH na curva da CR entre os instantes de 0 a 120 minutos é de $15,3 \%$. 


\subsubsection{Cortisol}

Condição Controle (CC): após repouso de trinta minutos, observa-se redução da secreção do cortisol de $17,21 \%$. A partir do instante 0 , a secreção hormonal permanece constante até os 60 minutos. Entre os 60 e os 75 minutos, ocorre elevação de 54,28\% de secreção hormonal. Segue-se redução equivalente, com ascensão total até o final dos procedimentos de $51,21 \%$ em relação ao instante de 0 minuto.

Condição de Recuperação (CR): não se observa variação de secreção hormonal significativa entre os -30 e 0 minutos. A partir daí, a secreção hormonal permanece constante, até os 45 minutos, quando, então, reduz-se lentamente até se estabilizar, aos 120 minutos. A redução de secreção hormonal entre 0 e 120 minutos é de 21,87\%. Durante todo o tempo, os valores de secreção do cortisol se mantiveram cerca de três vezes mais elevados em relação aos observados na CC.

\subsubsection{Adrenalina}

Condição Controle (CC): observa-se elevação de secreção hormonal de 15,54 \% entre -30 e 0 minutos. A partir desse instante, ocorre lenta subida dos níveis de adrenalina, com um aumento de $52,38 \%$ entre 0 e 45 minutos, seguida pela relativa estabilização dos valores até o instante de 90 minutos, quando ocorre queda de 15,55 \% em relação ao instante de 75 minutos. Então, ocorre nova elevação dos níveis hormonais, observando-se, aos 105 minutos, seus valores máximos, o que representa um aumento de 31,57 \% em relação ao instante de 90 minutos, sendo $55,55 \%$ acima dos valores observados no instante de 0 minuto. Até o final dos procedimentos, a secreção hormonal permanece constante.

Condição de Recuperação (CR): a condição de chegada ao laboratório é de 10,6 \% acima dos valores observados na CC. Com o repouso de 30 minutos, ocorre redução de 37,7 $\%$ de secreção hormonal, com ambas as condições (CC e CR) se iniciando em valores equivalentes. Então, a secreção de adrenalina prossegue constante, com pequena oscilação 
positiva aos 45 minutos, o que representa um aumento de $21,05 \%$ em relação ao instante de 0 minuto. Segue-se pequena queda, seguida por novo aumento de secreção hormonal, com um valor máximo atingido aos 105 minutos, o que representa um aumento de 76,31 \% em relação ao instante 0 . Segue-se queda rápida de $36,56 \%$ em relação ao valor máximo observado aos 105 minutos e somente de $10,52 \%$ acima do valor observado no instante 0 .

\subsubsection{Prolactina}

Condição Controle (CC): observa-se redução de 11,8 \% na secreção de prolactina entre -30 e 0 minutos. Essa queda prossegue até os 45 minutos, com uma redução de $23,71 \%$ em relação ao instante 0 . A partir desse instante, a secreção hormonal permanece constante até o final dos procedimentos. A queda total de secreção de prolactina entre 0 e 120 minutos é de $14,43 \%$.

Condição de Recuperação (CR): a secreção de prolactina permanece praticamente inalterada durante o repouso de 30 minutos. Então, ocorre uma queda da secreção hormonal, representando uma redução de 23,71 \% entre 0 e 45 minutos. A partir daí, durante a vivência, ocorre elevação da secreção de prolactina, atingindo um máximo aos 75 minutos, valor igual ao observado no instante 0 , com um incremento de $23,71 \%$. Desse instante em diante, ocorre redução progressiva da secreção hormonal, até o final dos procedimentos (queda de 21,16 \% entre os 75 e os 120 minutos), atingindo um valor final que representa uma redução de 20,58 $\%$ entre 0 e 120 minutos.

\subsubsection{TSH}

Condição Controle (CC): ocorre queda de 18,39 \% na secreção hormonal entre -30 e 0 minutos. A partir daí, até os 45 minutos, observa-se queda lenta dos valores de TSH de $19,71 \%$ entre 0 e 45 minutos. Então se observam duas ondas de secreção hormonal: uma pequena oscilação positiva do TSH entre 45 e 60 minutos de 8,7 \%, e uma outra, de 27,77\%, 
entre os instantes 90 e 105 minutos, atingindo, aos 120 minutos, os valores mínimos de secreção de TSH, o que representa uma queda, em relação ao instante 0 , de 26,76 \%.

Condição de Recuperação (CR): a secreção de TSH na condição de chegada ao laboratório não se altera com o repouso de 30 minutos. A partir daí, a curva de secreção de TSH da CR segue um perfil descendente até os 60 minutos, com uma redução total de $18 \%$ entre 0 e 60 minutos. A seguir, ocorre uma oscilação positiva de secreção hormonal entre os 60 e os 120 minutos, com um aumento máximo de 9,86\% em relação ao instante de 60 minutos, atingindo, aos 120 minutos, um valor cerca de $20 \%$ menor do que o do início dos procedimentos.

\subsubsection{GH}

Condição Controle (CC): a curva representativa da secreção de GH não se altera durante todo o procedimento, situando-se abaixo do limite inferior dos valores de referência do ensaio, apresentando uma elevação de $60 \%$ entre os instantes de 105 e 120 minutos.

Condição de Recuperação (CR): a secreção de GH praticamente não se altera com o repouso de 30 minutos, no entanto se situa em valores sensivelmente mais elevados do que os observados na CC. A curva da secreção do GH durante todo o procedimento é descendente e homogênea, atingindo os valores mais baixos aos 120 minutos, com uma redução de 30,18 \% em relação ao instante 0 . Ao longo de todo tempo, o nível de secreção de GH na CR se mostrou, em média, 8 vezes maior do que na $\mathrm{CC}$.

\section{Análise estatística}

Os resultados da análise estatística acham-se expressos no Quadro IV.

4.5. SUJEITO 5 - HLVF - sexo masculino, 59 anos. Diagnóstico pelo SCID/DSMIV: Transtorno de Ansiedade Generalizado (300.02). - BDI = 08 - HAM-A 11. Tipo Matutino do GMDRB. 
QUADRO IV - Sujeito 4 - valores de $\boldsymbol{p}$ : C-teste, Mann-Whitney (U-teste), p<0,05

\begin{tabular}{|c|c|c|}
\hline C-teste & U-teste (00-120) & U-teste (45-120) \\
\hline & 9 pontos & 6 pontos \\
\hline
\end{tabular}

$\begin{array}{lcccc}\text { Hormônio } & \text { CC } & \text { CR } & \text { CC x CR } & \text { CCxCR } \\ \text { ACTH } & \mathbf{0 , 0 0} & \mathbf{0 , 0 0} & 0,6581 & 0,8095 \\ \text { Cortisol } & 0,32 & \mathbf{0 , 0 0} & <\mathbf{0 , 0 0 0 1} & 0,6991 \\ \text { Adrenalina } & \mathbf{0 , 0 3} & 0,28 & 0,7910 & 0,0780 \\ \text { Prolactina } & \mathbf{0 , 0 3} & \mathbf{0 , 0 2} & <\mathbf{0 , 0 0 0 1} & \mathbf{0 , 0 4 5 0} \\ \text { TSH } & 0,36 & \mathbf{0 , 0 4} & <\mathbf{0 , 0 0 0 1} & 0,4230 \\ \text { GH } & 0,69 & \mathbf{0 , 0 0} & <\mathbf{0 , 0 0 0 1} & \mathbf{0 , 0 0 2 2}\end{array}$

Em negrito, os resultados estatisticamente significativos.

00-120 - (minutos) intervalo de valores utilizados para a análise estatística 45-120 - (minutos) intervalo de valores utilizados para a análise estatística 
Resumo: instante 0: início do Relaxamento. 15 minutos: início do Aprofundamento:30 minutos: fim do aprofundamento (sujeito dormiu). A partir dos 41 minutos: Recuperação, na qual ocorre a vivência. Dos 41 minutos aos 70 minutos: MMT. Aos 75 minutos: Decisão. Aos 90 minutos: identificação da Redecisão. Aos 92 minutos: inicia-se a Desprogramação. Aos 105 minutos: Programação Positiva. Aos 110 minutos: início do Retorno e Finalização.

Observações: durante todas fases, não se observou agitação psicomotora. O sujeito permaneceu em repouso. No fim do aprofundamento, na CR, o sujeito dormiu. No final dos procedimentos, o sujeito se sentia bem, orientado no espaço e no tempo, com bom contato com o ambiente. Foi submetido a acompanhamento psicoterápico subseqüente. Nível de intensidade da vivência: muito alto (referido pelo sujeito).

Resultado das dosagens hormonais: a Tabela $\mathrm{V}$ mostra os resultados das dosagens hormonais realizadas no sujeito 5, em ambas as condições (CC e CR).

Gráficos representativos das dosagens hormonais: as figuras 13, 14 e 15 exibem os gráficos representativos das variações hormonais observadas em ambas as condições (CC e $\mathrm{CR})$.

Descrição das curvas de secreção hormonal: as condições de chegada ao laboratório na CC e na CR são expressas pelos valores observados aos -30 minutos.

\subsection{1. АCTH}

Condição Controle (CC): a condição de chegada ao laboratório permanece constante após o repouso de 30 minutos. Depois, a secreção do ACTH exibe um perfil homogêneo com pequenas oscilações, até o final dos procedimentos, em valores praticamente indistinguíveis dos observados no instante 0 , com pequena uma queda de $4,34 \%$.

Condição de Recuperação (CR): a condição de chegada ao laboratório permanece constante após o repouso de 30 minutos. Observa-se uma tendência ascendente da curva de 


\section{TABELA V}

Resultados do sujeito 5 - dosagens hormonais, médias, desvios padrão, erros padrão, medianas e intervalos de confiança CC - condição controle CR - condição de recuperação
DP - desvio padrão
DP - erro padrão
IC - intervalo de confiança

Os cálculos estatísticos foram realizados utilizando-se os valores observados entre os instantes de 0 e 120 minutos

\begin{tabular}{|c|c|c|c|c|c|c|c|c|c|c|c|c|}
\hline $\begin{array}{c}\text { Tempo } \\
\text { min }\end{array}$ & $\begin{array}{r}\text { CTH-CC } \\
\mathrm{pg} / \mathrm{ml}\end{array}$ & $\begin{array}{r}\text { ACTH-CR } \\
\mathrm{pg} / \mathrm{ml}\end{array}$ & $\begin{array}{r}\text { ADR-CC } \\
\mathrm{pg} / \mathrm{ml}\end{array}$ & $\begin{array}{r}\text { ADR-CR } \\
\mathrm{pg} / \mathrm{ml}\end{array}$ & $\begin{array}{r}\text { CORT-CC } \\
u g / d l\end{array}$ & $\begin{array}{r}\text { CORT-CR } \\
u g / d l\end{array}$ & $\begin{array}{r}\text { PRL-CC } \\
\mathrm{ng} / \mathrm{ml}\end{array}$ & $\begin{array}{r}\mathrm{PRL}-\mathrm{CR} \\
\mathrm{ng} / \mathrm{ml}\end{array}$ & $\begin{array}{r}\text { TSH-CC } \\
\mathrm{uUl} / \mathrm{ml}\end{array}$ & $\begin{array}{r}\text { TSH-CR } \\
\mathrm{uUl} / \mathrm{ml}\end{array}$ & $\begin{array}{r}\mathrm{GH}-\mathrm{CC} \\
\mathrm{ng} / \mathrm{ml}\end{array}$ & $\begin{array}{r}\mathrm{GH}-\mathrm{CR} \\
\mathrm{ng} / \mathrm{ml}\end{array}$ \\
\hline-30 & 90,00 & 99,00 & 99,00 & 99,00 & 13,50 & 14,80 & 5,80 & & & 1,745 & 0,13 & 0,24 \\
\hline 0 & 92,00 & 98,00 & 90,00 & 87,00 & 13,20 & & 4,90 &, 20 & & 1,193 & ,08 & 0,12 \\
\hline 15 & 8,00 & 95,00 & 87,00 & 81,00 & & & 4,90 & 4,60 & & & ,07 & 0,08 \\
\hline 30 & & & & 0 & & & & & & & & 0,07 \\
\hline 45 & 00 & 3,00 & 0 & 00 & 1,80 & & & 3.8 & & 263 & &, 13 \\
\hline 60 & & 0 & & & & & & & & & & 0,48 \\
\hline 75 & & & & & & & &, 80 & & & & 2,09 \\
\hline 90 & , 00 & 0 & 93, & & 80 & & & 30 & & & & 4,02 \\
\hline & & & & & & & & & & & & 4,71 \\
\hline & & & 0 & & & & & 30 & & & 09 & 5,34 \\
\hline Iédia & 7,2220 & 100,5600 & 85,3330 & 9,6670 & 3,1890 & 10,0220 & 0440 & 8780 & 1,5960 & 1,3930 & 033 & 8930 \\
\hline & 1890 & 4,5580 & 12,1860 & 11,3910 & 0480 & 1,8450 & 509 & 2,0270 & 0,1009 & 0,2287 & 0,0296 & 2,2150 \\
\hline$P$ & 8296 & 1,5190 & 4,0620 & 3,7970 & 3494 & 0,6150 & 0,0503 & 0,6755 & 0,0034 & 0,0762 & 0,0099 & 0,7382 \\
\hline & 88,0000 & 100,0000 & 90,0000 & 98,0000 & 12,8000 & 9,7000 & 5,1000 & 4,6000 & 1,6220 & 1,2770 & 0,0900 & 0,4800 \\
\hline$C<95 \%$ & 85,3090 & 97,0520 & 75,9660 & 90,9110 & 12,3830 & 8,6040 & 4,9280 & 4,3200 & 1,5190 & 1,2170 & 0,0806 & 0,1910 \\
\hline$>95 \%$ & 89,1350 & 104,0600 & 94,7000 & 108,4200 & 13,9950 & 11,4400 & 5,1600 & 7,4360 & 1,6740 & 1,5690 & 0,1261 & 3,596 \\
\hline
\end{tabular}


A

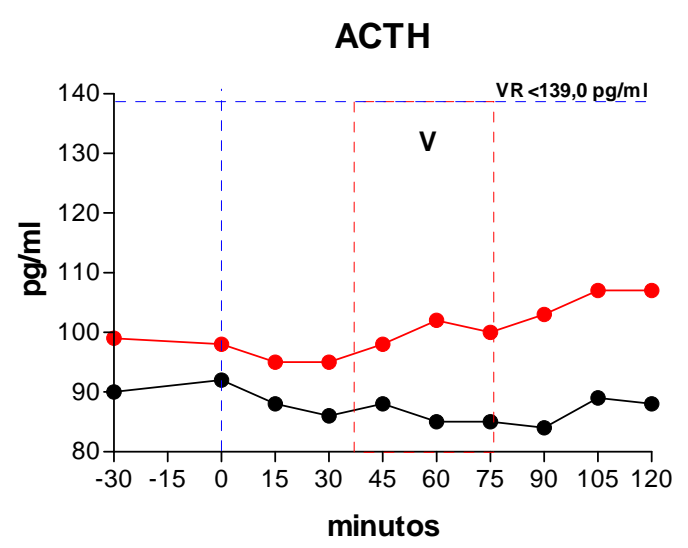

C

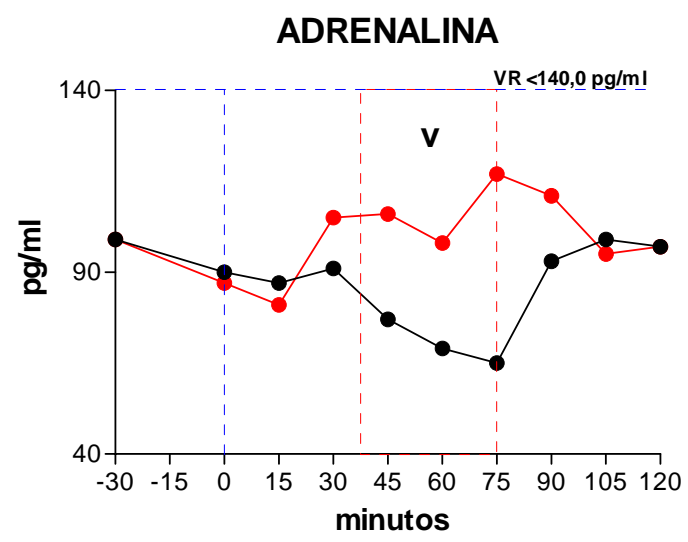

$\mathbf{E}$

TSH

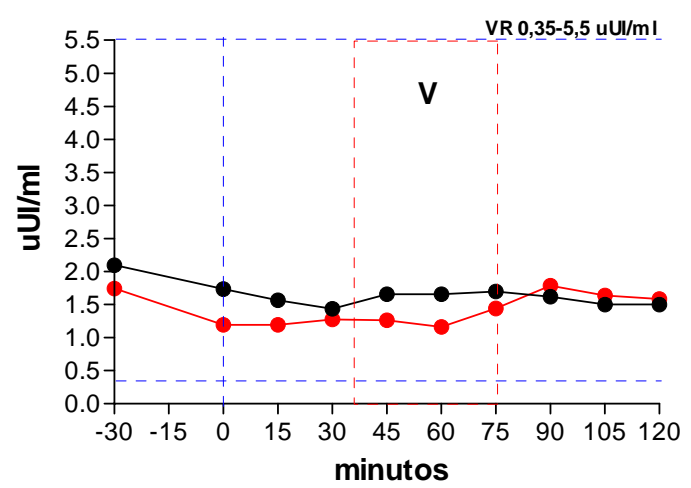

B

\section{CORTISOL}

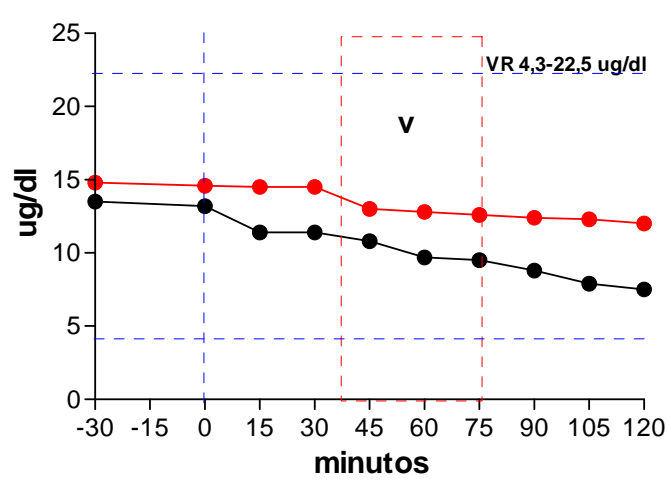

D

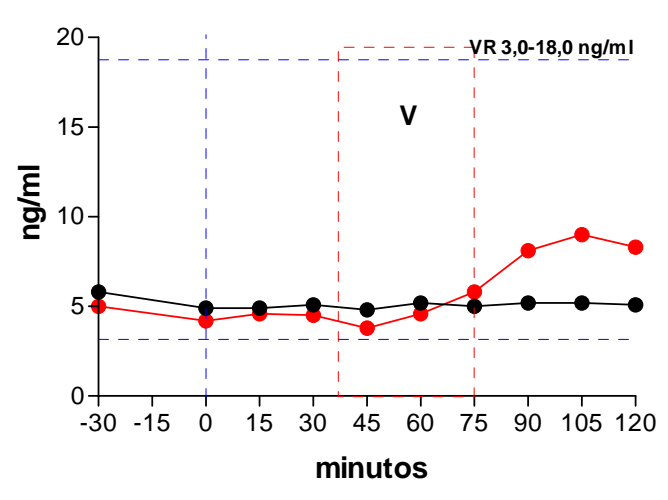

$\mathbf{F}$

GH

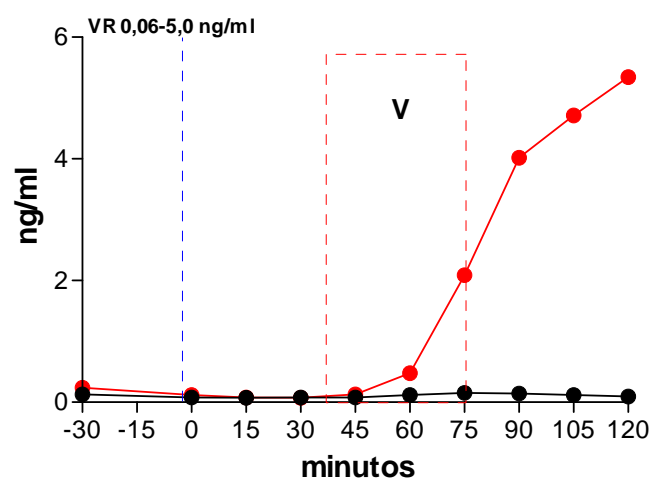

Figura 13 - curvas de tempo e resposta das variações hormonais do sujeito 5 submetido à recuperação de memórias traumáticas, .

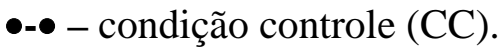

$\bullet-\bullet$ - condição de recuperação (CR).

V - vivência.

VR - valores de referência para o ensaio 
A

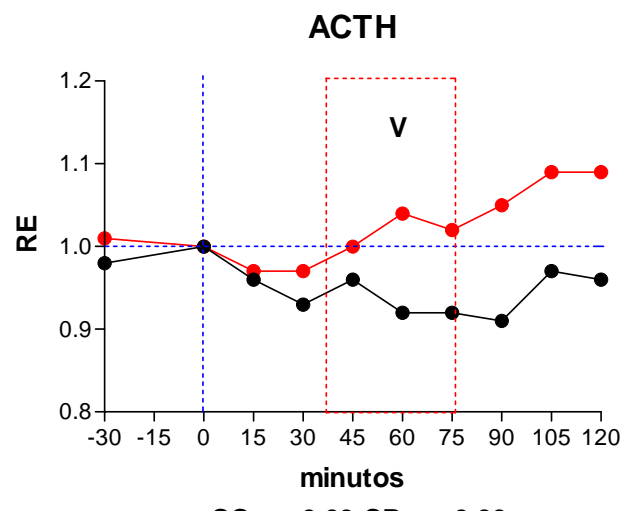

CC: $p=0,09$ CR: $p=0,00$

C

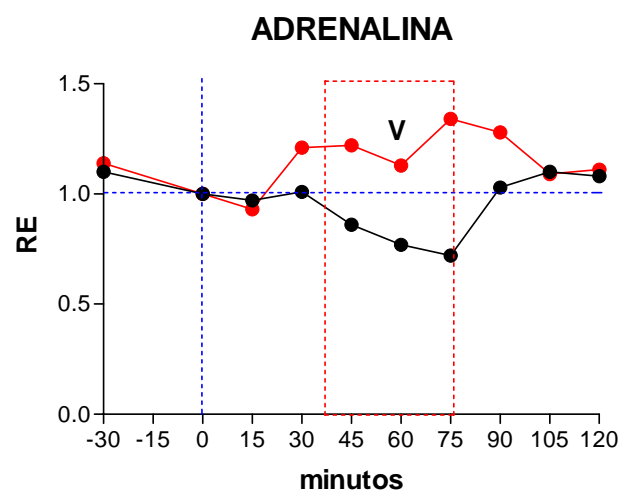

CC: $p=0,04$ CR: $p=0,11$

E

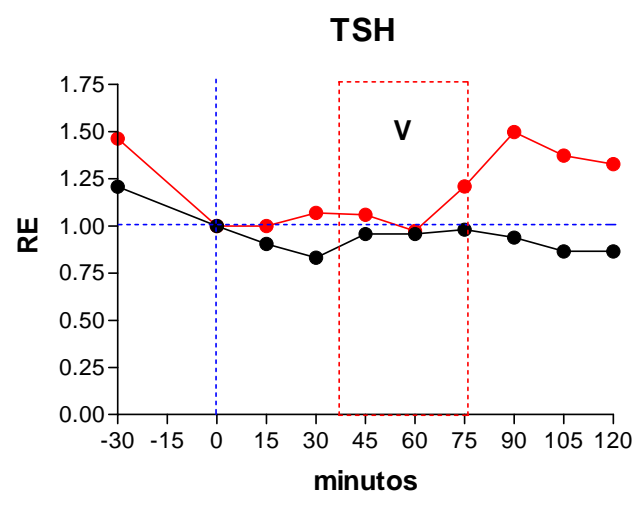

CC: $p=0,15$ CR: $p=0,01$
B

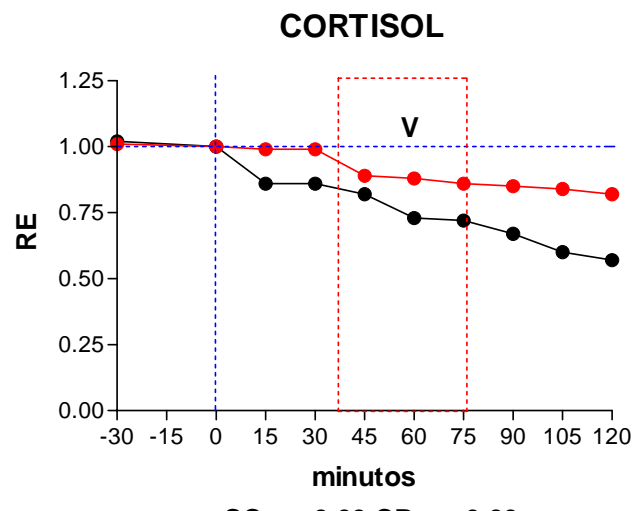

CC: $p=0,00$ CR: $p=0,00$

D

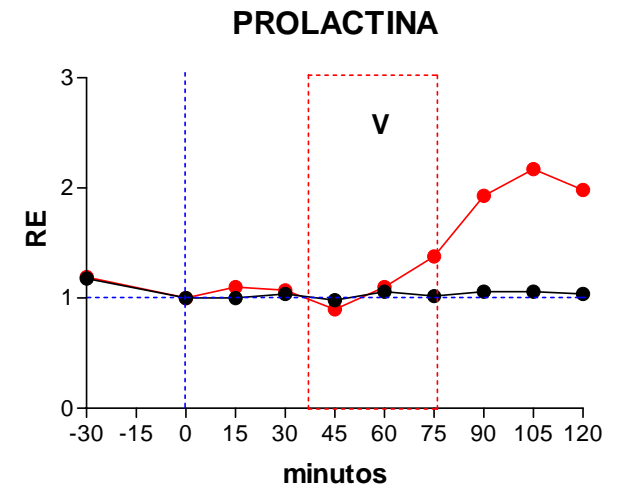

CC: $p=0,44$ CR: $p=0,00$

F

GH: CCXCR

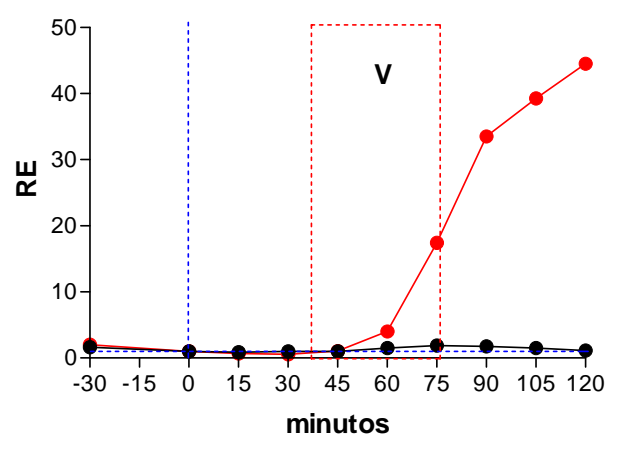

CC: $p=0,01$ CR: $p=0,00$

Figura 14 - curvas rescalonadas de tempo e resposta das variações hormonais do sujeito 5 submetido à recuperação de memórias traumáticas.

$\bullet-\bullet$ - condição controle (CC).

$\bullet-\bullet$ - condição de recuperação (CR).

V - vivência. 
A

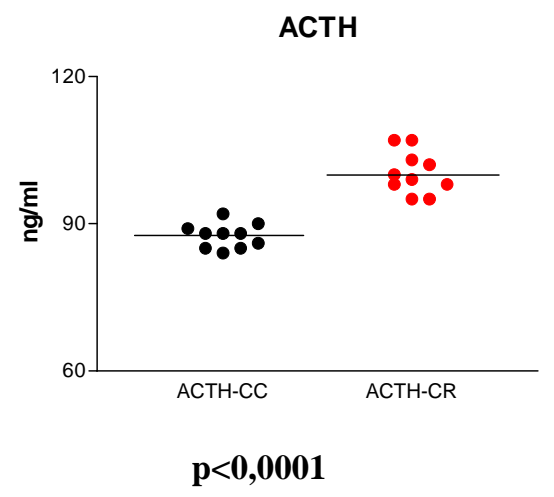

C

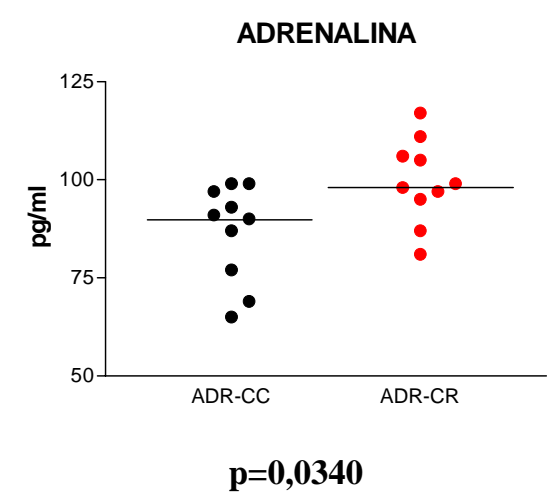

$\mathbf{E}$

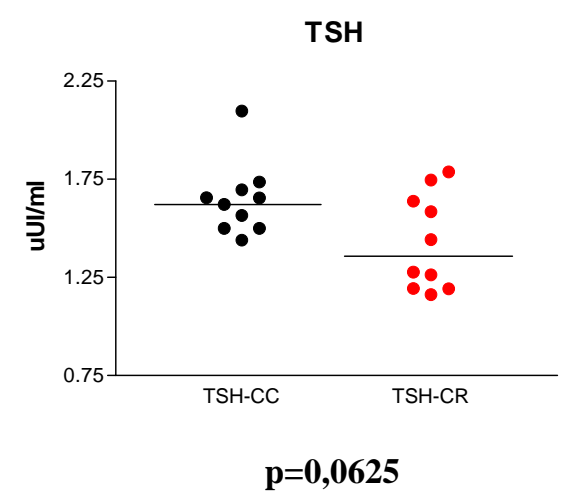

B

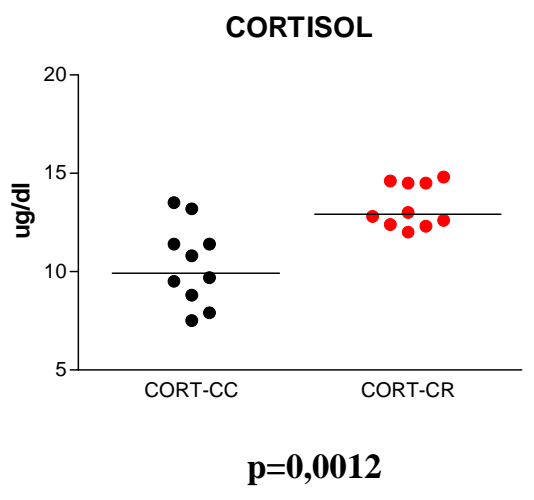

D

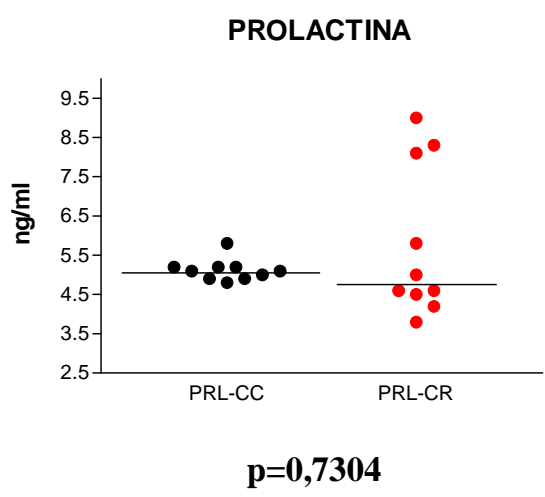

$\mathbf{F}$

GH

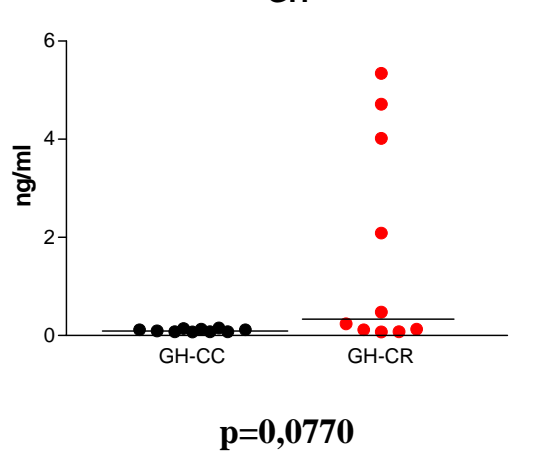

Figura 15 - variações hormonais do em função do tempo do sujeito 5 submetido à recuperação de memórias traumáticas, expressas em medianas. Mann-Whiney, U teste, $\mathrm{p}<0,005$.

$\bullet-\bullet$ - condição controle (CC).

•-• - condição de recuperação (CR). 
secreção do ACTH ao longo da CR, situando-se, ao final dos procedimentos, 8,08\% acima dos valores observados no instante 0 .

\subsubsection{Cortisol}

Condição Controle (CC): após o repouso de 30 minutos, a secreção de cortisol permanece estável. Depois, observa-se queda constante e homogênea, até atingir o valor mínimo observado aos 120 minutos, representando uma queda de 43,18 \% em relação ao instante 0

Condição de Regressão (CR): a condição de chegada ao laboratório equivale à da CC. A partir daí, a curva de secreção de cortisol segue constante, apresentando uma queda de $13,69 \%$ entre 0 e 75 minutos. A curva de secreção permanece em queda constante até atingir o valor mínimo observado aos 120 minutos, com uma queda, em relação ao instante 0 , de 17,8 \%. Chama a atenção o fato de que durante toda a CR os valores de secreção do cortisol se situam acima dos valores de referência do ensaio.

\subsubsection{Adrenalina}

Condição Controle (CC): durante o repouso de 30 minutos, observa-se queda de 9,09 \% na secreção de adrenalina. A partir daí, a produção hormonal se estabiliza até os 30 minutos, seguida por nova queda, que prossegue até os 75 minutos, representando uma redução de 27,77 \% em relação ao tempo 0 . Então, ocorre novo incremento de secreção hormonal que atinge, aos 105 minutos, um valor 52,3\% acima dos observados aos 75 minutos. Aos 120 minutos, o valor atingido é de 7,77\% acima dos observados no instante de 0.

Condição de Recuperação (CR): a curva de secreção de adrenalina segue a curva da CC até os 15 minutos, quando, então, ocorre uma subida, atingindo, aos 45 minutos, um valor $21,83 \%$ mais elevado que o observado no tempo 0 . Entre 45 e 75 minutos, ocorre uma queda de $10,38 \%$ na secreção hormonal. Em seguida, nova subida da secreção hormonal, atingindo 
um máximo aos 75 minutos, o que representa um incremento de 34,48\% em relação ao instante 0 e 44,44\% em relação aos 15 minutos. Então, a secreção hormonal decresce, e a curva da CR se encontra com a curva da CC aos 105 minutos, correndo juntas até o final dos procedimentos.

\subsubsection{Prolactina}

Condição Controle (CC): a condição de chegada ao laboratório se situa ligeiramente acima do limite inferior dos valores de referência para o ensaio. A partir daí, durante todo o procedimento, permanece constante.

Condição de Recuperação (CR): o perfil de secreção de prolactina segue o perfil de secreção observado durante a CC. Somente aos 75 minutos é que a curva se altera, apresentando aumento na secreção hormonal, atingindo um máximo aos 105 minutos, de $114,85 \%$ em relação ao instante 0 .

\subsubsection{TSH}

Condição Controle (CC): após o repouso, e até os 30 minutos, ocorre queda constante da secreção hormonal, quando atinge o valor mais baixo observado durante os procedimentos: queda de 17,06 \% em relação ao instante 0 . A partir daí, a curva de secreção de TSH permanece praticamente constante até o final do procedimento com uma queda de $13,8 \%$ em relação ao instante 0 .

Condição de Recuperação (CR): A condição de chegada ao laboratório é de 16,75 \% abaixo do observado na CC. Com o repouso de 30 minutos, ocorre queda de 31,06\% na secreção hormonal. Os valores permanecem constantes e inferiores aos observados durante a CC. Somente aos 60 minutos, a secreção hormonal aumenta, ultrapassa os valores observados durante a CC, atingindo, aos 90 minutos, o maior valor observado, o que representa um incremento de 95,65 \% em relação ao instante de 45 minutos, 114,28\% em relação ao instante 
0 e 136,84 \% em relação do instante de 60 minutos. Então, segue o perfil de secreção da CC, até o final dos procedimentos, num valor 97,61 \% acima do valor observado no instante 0 .

\subsubsection{GH}

Condição Controle (CC): a secreção de GH, a partir do instante de chegada ao laboratório, exibe uma onda positiva entre os instantes de 45 e 120 minutos, com um incremento de cerca de $87 \%$ na secreção hormonal entre 45 e 75 minutos.

Condição de Recuperação (CR): a secreção de GH, a partir do instante de chegada ao laboratório permanece constante até os 45 minutos, dentro da fase de vivência, quando a curva de secreção hormonal apresenta progressivo aumento, que se acelera até os 120 minutos, num valor que excede o limite superior dos valores de referência para o ensaio, representando um incremento de $4350 \%$ em relação ao instante 0 .

\section{Análise estatística}

Os resultados da análise estatística acham-se expressos no Quadro V.

4.6. SUJEITO 6 - ASTR - sexo masculino, 52 anos. Diagnóstico pelo SCID/DSMIV: Fobia social (300.23) - BDI $=1-$ HAM-A $=1$. Tipo Matutino do GMDRB.

Resumo: instante 0: início do Relaxamento. 30 minutos: início do Aprofundamento: a partir dos 45 minutos dá-se a vivência, incluindo o MMT, que ocorre aos 104 minutos. Aos 105 minutos: identificação da Decisão e Redecisão. 120 minutos: fim dos procedimentos.

Observações: durante o Relaxamento e o Aprofundamento: sujeito com dificuldades de relaxar (levemente gripado). Dos 76 aos 105 minutos, o sujeito apresentou leve agitação psicomotora, sem comprometer os processos destinados à coleta de material, pois permaneceu deitado. Seguindo o protocolo, a coleta de material para as dosagens hormonais foi interrompida com a amostra de 120 minutos, antes das fases de Desprogramação, Programação Positiva, Retorno e Finalização. No fim dos procedimentos, o sujeito se sentia bem, orientado no espaço e no tempo, com bom contacto com o ambiente. Foi submetido a 
QUADRO V - Sujeito 5 - valores de $\boldsymbol{p}$ : C-teste, Mann-Whitney (U-teste), p<0,05

\begin{tabular}{lcccc} 
& \multicolumn{2}{c}{ C-teste } & U-teste $(00-120)$ & U-teste (45-120) \\
& & & 9 pontos & 6 pontos \\
Hormônio & CC & CR & CC x CR & CCxCR \\
ACTH & 0,09 & $\mathbf{0 , 0 0}$ & $<\mathbf{0 , 0 0 0 1}$ & $\mathbf{0 , 0 0 2 2}$ \\
Cortisol & $\mathbf{0 , 0 0}$ & $\mathbf{0 , 0 0}$ & $\mathbf{0 , 0 0 1 2}$ & $\mathbf{0 , 0 0 6 5}$ \\
Adrenalina & $\mathbf{0 , 0 4}$ & 0,11 & $\mathbf{0 , 0 3 4 0}$ & $\mathbf{0 , 0 0 4 3}$ \\
Prolactina & 0,44 & $\mathbf{0 , 0 0}$ & 0,7304 & 0,0649 \\
TSH & 0,15 & $\mathbf{0 , 0 1}$ & 0,0625 & $\mathbf{0 , 0 0 4 3}$ \\
GH & $\mathbf{0 , 0 1}$ & $\mathbf{0 , 0 0}$ & 0,7770 & $\mathbf{0 , 0 4 1 1}$ \\
\hline
\end{tabular}

Em negrito, os resultados estatisticamente significativos.

00-120 - (minutos) intervalo de valores utilizados para a análise estatística 45-120 - (minutos) intervalo de valores utilizados para a análise estatística 
acompanhamento psicoterápico subseqüente. Nível de intensidade da vivência: muito alto (referido pelo sujeito).

Resultado das dosagens hormonais: a Tabela VI mostra os resultados das dosagens hormonais realizadas no sujeito 6 , em ambas as condições (CC e CR).

Gráficos representativos das dosagens hormonais: as figuras 16,17 e 18 exibem os gráficos representativos das variações hormonais observadas em ambas as condições (CC e $\mathrm{CR})$.

Descrição das curvas de secreção hormonal: as condições de chegada ao laboratório na CC e na CR são expressas pelos valores observados aos -30 minutos.

\subsubsection{ACTH}

Condição Controle (CC): após o repouso de trinta minutos, o nível de ACTH não se altera, mantendo-se constante até os 45 minutos dos procedimentos, quando apresenta perfil ascendente, com dois picos de secreção. O primeiro, aos 60 minutos, representando um incremento de 5,2 \% e aos 90 minutos, representando um incremento de 7,14 \%, em relação ao instante 0 . Após essa elevação, a secreção de $\mathrm{ACTH}$ decai para atingir um valor apenas $3,77 \%$ acima do valor inicial.

Condição de Recuperação (CR): até o instante de 30 minutos, apesar do perfil descendente, a variação observada não é significativa em relação ao instante de 0 minuto. Entre os 30 e os 45 minutos, a secreção de ACTH sobe 4,26 \%, representando um aumento de apenas 3,0 \% em relação ao instante de 0 minuto. A partir daí a secreção do ACTH permanece constante durante toda a vivência, retornando ao valor inicial aos 120 minutos dos procedimentos. 


\section{TABELA VI}

Resultados do sujeito 6 - dosagens hormonais, médias, desvio padrão, erro padrão, medianas e intervalos de confiança CC - condição controle $\quad$ CR - condição de recuperação

DP - desvio padrão EP - erro padrão IC - intervalo de confiança

Os cálculos estatísticos foram realizados utilizando-se os valores observados entre os instantes de 0 e 120 minutos.

$\begin{array}{crrrrrrrrrrrr}\text { Tempo } & \text { ACTH-CC } & \text { ACTH-CR } & \text { ADR-CC } & \text { ADR-CR CORT-CC CORT-CR } & \text { PRL-CC } & \text { PRL-CR } & \text { TSH-CC } & \text { TSH-CR } & \text { GH-CC } & \text { GH-CR } \\ \text { min } & \mathrm{pg} / \mathrm{ml} & \mathrm{pg} / \mathrm{ml} & \mathrm{pg} / \mathrm{ml} & \mathrm{pg} / \mathrm{ml} & \mathrm{ug} / \mathrm{dl} & \mathrm{ug} / \mathrm{dl} & \mathrm{ng} / \mathrm{ml} & \mathrm{ng} / \mathrm{ml} & \mathrm{uUl} / \mathrm{ml} & \mathrm{uUl} / \mathrm{ml} & \mathrm{ng} / \mathrm{ml} & \mathrm{ng} / \mathrm{ml} \\ -30 . & 98,30 & 101,20 & 29,00 & 28,00 & 8,90 & 10,10 & 7,10 & 7,00 & 1,336 & 1,338 & 0,10 & 0,11 \\ 0 & 98,00 & 99,70 & 31,00 & 36,00 & 9,00 & 10,70 & 6,20 & 8,30 & 1,332 & 1,345 & 0,09 & 0,10 \\ 15 & 98,70 & 98,50 & 30,00 & 35,00 & 8,60 & 10,50 & 6,20 & 8,00 & 1,327 & 1,345 & 0,09 & 0,13 \\ 30 & 99,50 & 98,70 & 29,00 & 33,00 & 9,30 & 10,10 & 6,50 & 7,60 & 1,328 & 1,358 & 0,07 & 0,08 \\ 45 & 98,20 & 102,70 & 31,00 & 32,00 & 9,20 & 9,60 & 6,10 & 7,50 & 1,326 & 1,360 & 0,08 & 0,10 \\ 60 & 103,10 & 101,30 & 30,00 & 29,00 & 9,10 & 9,70 & 6,30 & 6,90 & 1,330 & 1,342 & 0,07 & 0,10 \\ 75 & 99,80 & 100,70 & 30,00 & 28,00 & 8,70 & 10,30 & 6,40 & 7,00 & 1,331 & 1,340 & 0,11 & 0,09 \\ 90 & 105,00 & 100,50 & 30,00 & 31,00 & 8,60 & 10,00 & 6,00 & 7,10 & 1,326 & 1,335 & 0,08 & 0,09 \\ 105 & 102,30 & 101,20 & 27,00 & 30,00 & 9,30 & 10,20 & 6,10 & 7,20 & 1,329 & 1,338 & 0,09 & 0,10 \\ 120 & 101,70 & 99,80 & 28,00 & 29,00 & 9,10 & 11,00 & 5,80 & 7,60 & 1,327 & 1,337 & 0,10 & 0,11 \\ \text { Média } & 100,7000 & 100,3400 & 29,5560 & 31,4440 & 8,9890 & 10,2330 & 6,1780 & 7,4670 & 1,3280 & 1,3440 & 0,0867 & 0,1000 \\ \text { DP } & 2,4390 & 1,3310 & 1,3330 & 2,7890 & 0,2848 & 0,4528 & 0,2108 & 0,4690 & 0,0022 & 0,0089 & 0,0132 & 0,0141 \\ \text { EP } & 0,8131 & 0,4435 & 0,4444 & 0,9296 & 0,0949 & 0,1509 & 0,0703 & 0,1563 & 0,0007 & 0,0030 & 0,0044 & 0,0047 \\ \text { Mediana } & 99,8000 & 100,5000 & 30,0000 & 31,0000 & 9,1000 & 10,2000 & 6,2000 & 7,5000 & 1,3280 & 1,3420 & 0,0900 & 0,1000 \\ \text { IC }<95 \% & 98,8250 & 99,3220 & 28,5310 & 29,3010 & 8,7700 & 9,8850 & 6,0160 & 7,1060 & 1,3270 & 1,3380 & 0,0765 & 0,0891 \\ \text { IC>95\% } & 102,5700 & 101,3700 & 30,5800 & 33,5880 & 9,2080 & 10,5810 & 6,3400 & 7,8270 & 1,3300 & 1,3510 & 0,0968 & 0,1109\end{array}$


A

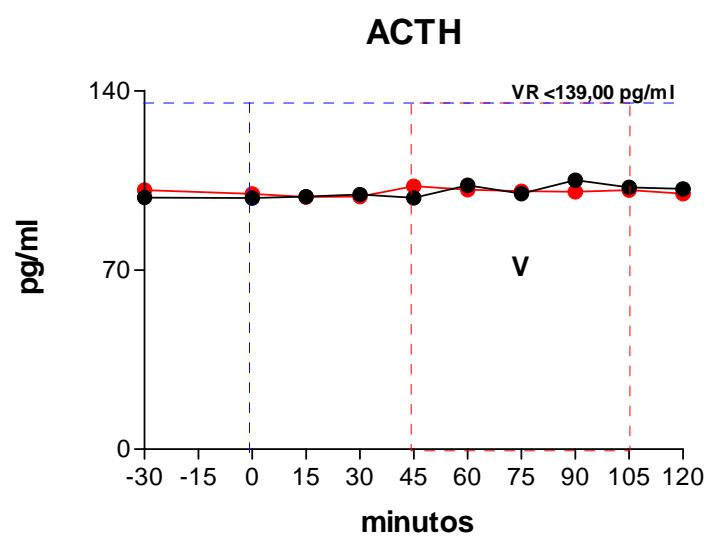

C

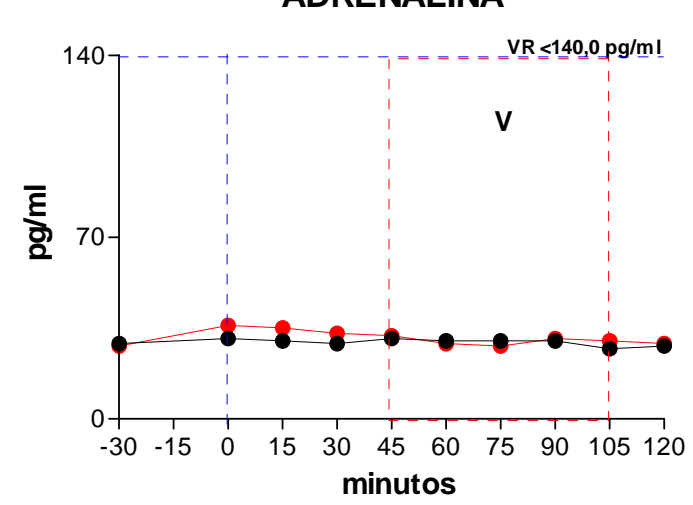

$\mathbf{E}$

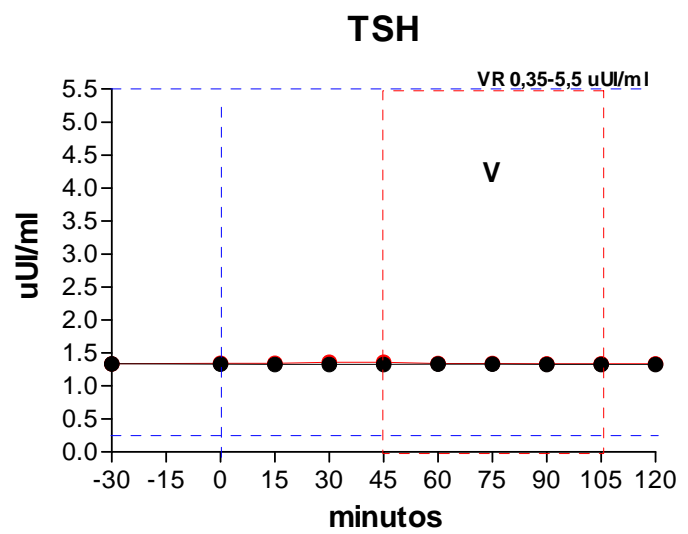

B

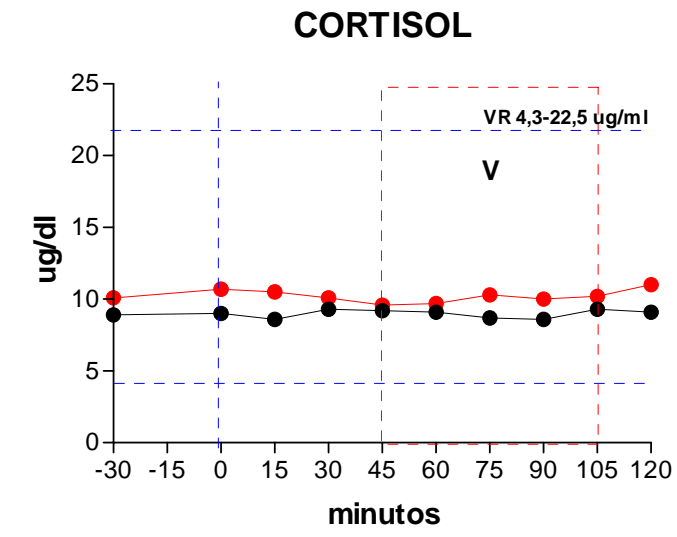

D

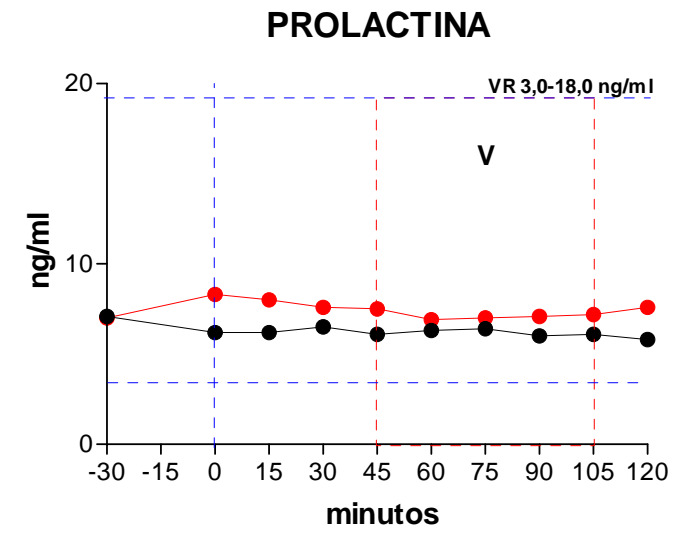

$\mathbf{F}$

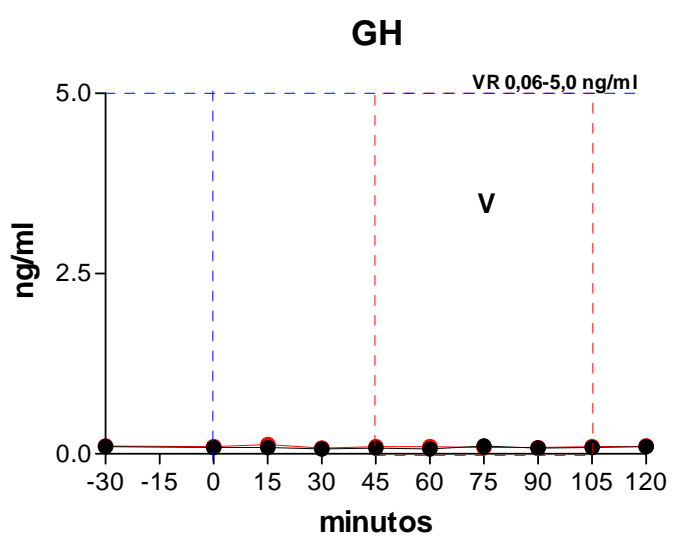

Figura 16 - curvas de tempo e resposta das variações hormonais do sujeito 6 submetido à recuperação de memórias traumáticas, .

$\bullet-\bullet$ - condição controle (CC).

$\bullet-\bullet$ - condição de recuperação (CR).

V - vivência.

VR - valores de referência para o ensaio 
A

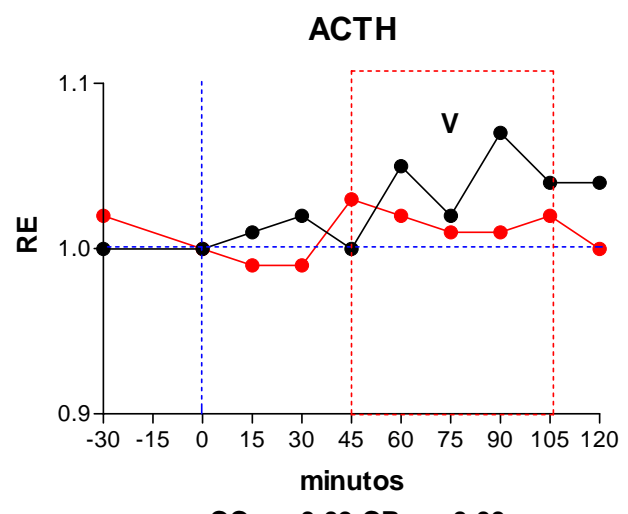

CC: $p=0,09$ CR: $p=0,00$

C

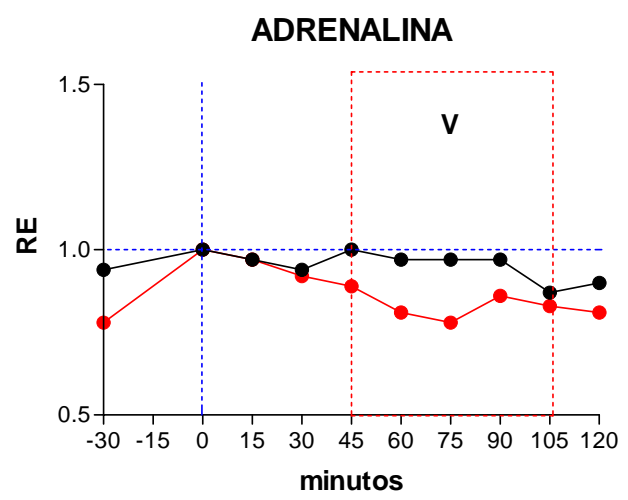

CC: $p=0,04$ CR: $p=0,11$

$\mathbf{E}$

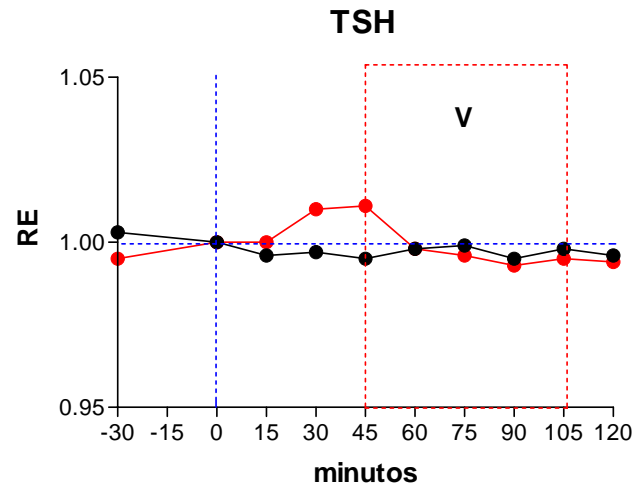

CC: 0,15 CR: $p=0,01$
B

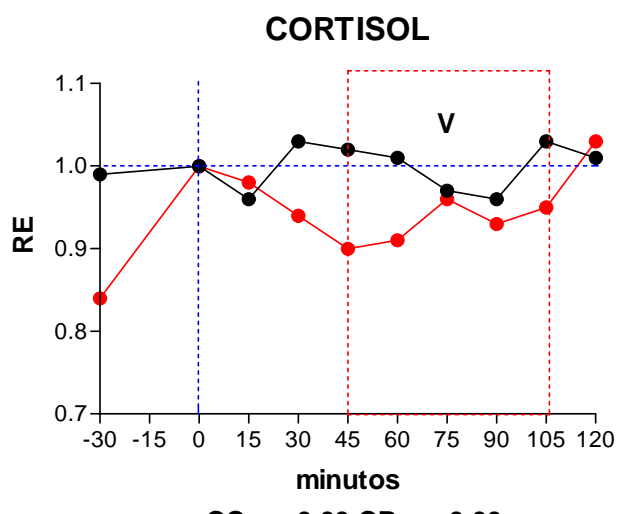

CC: $p=0,00$ CR: $p=0,00$

D

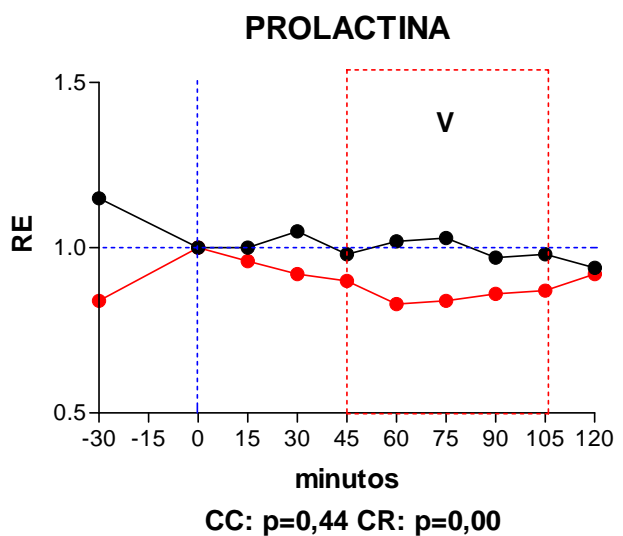

$\mathbf{F}$

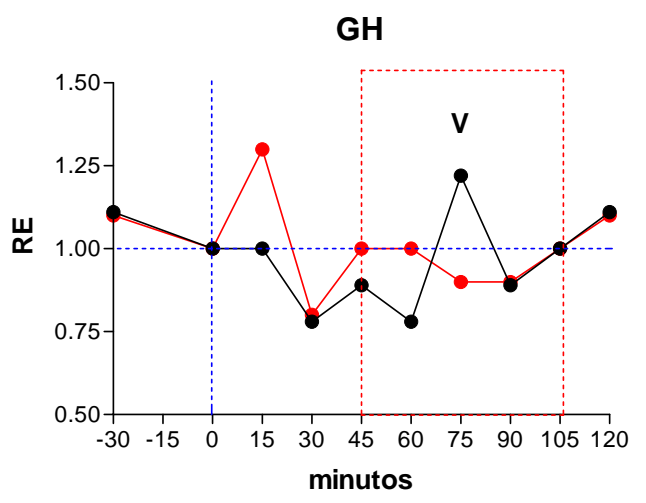

CR: $p=0,01$ CR: $p=0,00$

Figura 17 - curvas rescalonadas de tempo e resposta das variações hormonais do sujeito 6 submetido à recuperação de memórias traumáticas.

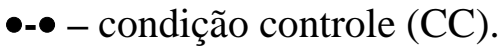

$\bullet-\bullet$ - condição de recuperação (CR).

V - vivência. 
A

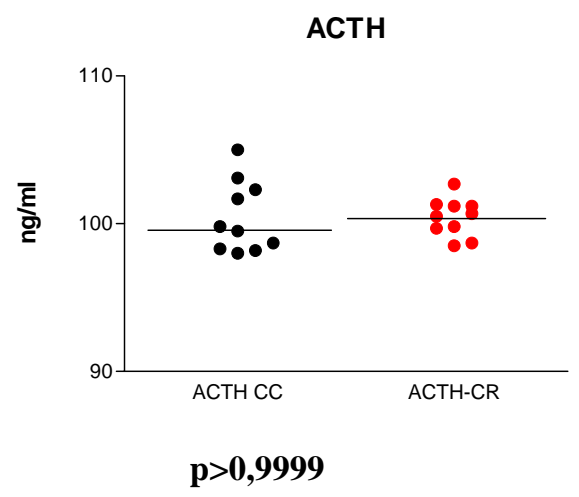

C

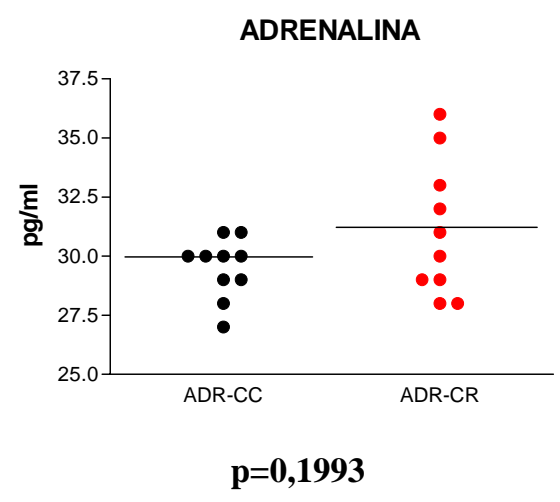

$\mathbf{E}$

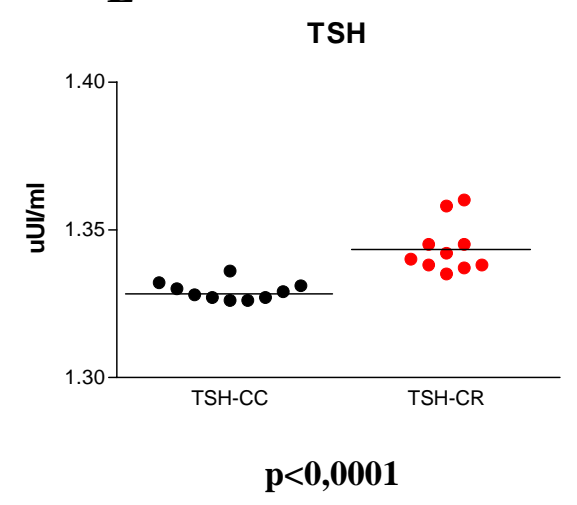

B

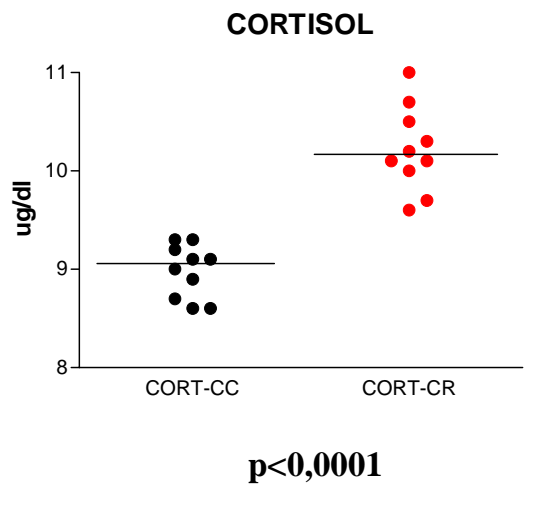

D

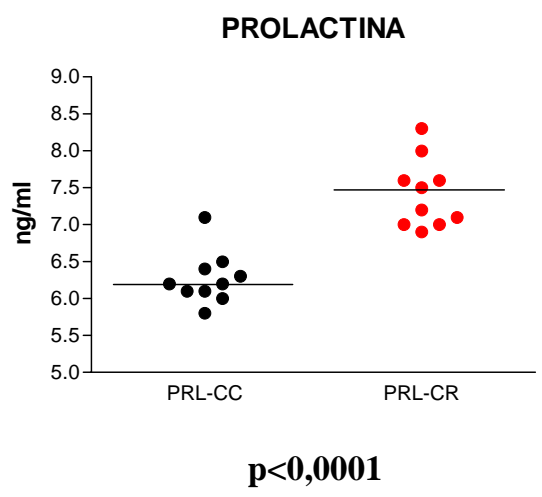

$\mathbf{F}$

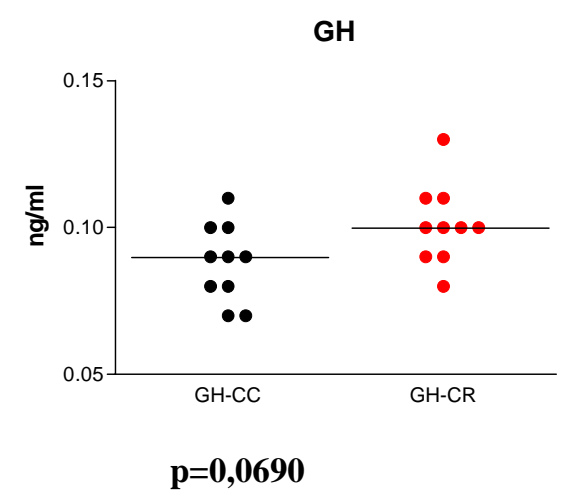

Figura 18 - variações hormonais em função do tempo do sujeito 6 submetido à recuperação de memórias traumáticas, expressas em medianas. Mann-Whiney, U teste, $\mathrm{p}<0,005$.

$\bullet-\bullet$ - condição controle (CC).

•-• - condição de recuperação (CR). 


\subsubsection{Cortisol}

Condição Controle (CC): a condição de chegada ao laboratório não se alterou significativamente após o repouso de trinta minutos e manteve-se relativamente constante até o final dos procedimentos.

Condição de Recuperação (CR): a condição de chegada ao laboratório é 13,48\% mais elevado do que o ponto correspondente da curva da CC. Após o repouso de trinta minutos, observa-se elevação da secreção hormonal de 5,94 \%. A partir daí, com um perfil mais elevado do que a curva da $\mathrm{CC}$, a secreção do cortisol cai progressivamente até os 45 minutos, atingindo um valor $10,28 \%$ mais baixo do que o observado no início dos procedimentos. Aos 30 e aos 45 minutos, os valores observados são indistinguíveis dos mesmos valores observados na CC. Então, a partir dos 45 minutos, o perfil de secreção do cortisol inverte-se, tornando-se ascendente durante toda a vivência, até atingir o valor máximo observado aos 120 minutos, representando uma elevação de 14,58 \% em relação aos 45 minutos, e sendo indistinguível do valor observado no início dos procedimentos.

\subsubsection{Adrenalina}

Condição Controle (CC): a condição de chegada ao laboratório não se altera significativamente após o repouso de trinta minutos e mantém-se em queda até os 120 minutos, quando atinge um valor de apenas $14,81 \%$ menor do que no instante 0 minuto.

Condição de Recuperação (CR): a condição de chegada ao laboratório é indistinguível do ponto correspondente da curva da CC, elevando-se $28,57 \%$ durante o repouso de trinta minutos. A partir daí, com um perfil mais elevado do que a curva da $\mathrm{CC}$, a secreção da adrenalina cai progressivamente até os 75 minutos, atingindo um valor idêntico ao valor de chegada, ao laboratório, isto é, $28,75 \%$ mais baixos do que o valor observado no instante 0 . Dos 75 aos 90 minutos, a secreção da adrenalina sofre um aumento de 10,71\% e, 
depois, apresenta nova queda até o fim dos procedimentos, representando uma redução total de 19,44\% em relação instante 0 .

\subsubsection{Prolactina}

Condição Controle (CC): durante o repouso de trinta minutos, observa-se queda da secreção hormonal de 12,67 \%. A partir daí, a curva de secreção de prolactina exibe um perfil médio descendente, atingindo o valor mínimo observado nessa condição aos 120 minutos, representando uma queda de $6,45 \%$ em relação ao instante 0 .

Condição de Recuperação (CR): durante o repouso de trinta minutos, observa-se elevação da secreção de prolactina de 18,57 \%. A partir do instante 0 , os níveis de prolactina diminuem 16,86 \% até os 60 minutos. Então, sofrem uma deflexão positiva, coincidente com a vivência, passando a ser ascendentes, atingindo, aos 120 minutos, valores 10,44 \% acima dos observados aos 60 minutos, mas $8,43 \%$ mais baixos do que os observados no instante 0 .

\subsubsection{TSH}

Condição Controle (CC): a partir do instante de chegada ao laboratório, a secreção de TSH se mantém constante durante e até o final dos procedimentos.

Condição de Recuperação (CR): a condição de chegada ao laboratório é indistinguível do ponto correspondente da curva da CC. A partir daí, ocorre um perfil de secreção de TSH ligeiramente ascendente, atingindo, aos 45 minutos, o valor máximo observado durante os procedimentos da $\mathrm{CR}$, representando um aumento de $1,11 \%$ em relação ao instante 0 . Entre 45 e 75 minutos, os valores caem $1,47 \%$ e, a seguir, correm paralelamente aos valores observados na curva da CC.

\subsubsection{GH}

Condição Controle (CC): a partir do instante de chegada ao laboratório, incluindo o repouso de 30 minutos, o perfil de secreção do GH é descendente até os 60 minutos. Entre os 60 e os 75 minutos, ocorre aumento de $57,14 \%$ o que atinge um valor de $22,22 \%$ maior do 
que o observado no instante 0 . Então, entre 75 e 90 minutos, ocorre nova queda de $27,27 \%$ da secreção do GH. Assim, o perfil da curva de secreção se inverte, com aumento da secreção do $\mathrm{GH}$, atingindo, aos 120 minutos, um valor $11,0 \%$ acima do observado no instante de 0 minuto.

Condição de Recuperação (CR): observa-se uma redução de secreção de GH de 9 \% após o repouso de 30 minutos, valores indistinguíveis dos pontos correspondentes da curva da CC. Entre o instante de 0 e 15 minutos, ocorre uma elevação de $30 \%$ da secreção do GH. Entre os 15 e os 30 minutos, a curva de secreção do GH se reduz, atingindo, aos 30 minutos, valor indistinguível do observado na curva da CC. Entre os 30 e 45 minutos, a secreção do GH apresenta aumento de $25 \%$, atingindo valor idêntico ao observado na condição de chegada. A partir deste momento, até os 90 minutos, a secreção do GH se mantém constante, apresentando um segmento ascendente no final dos procedimentos, entre os 90 e os 120 minutos, o que representa, entre esses tempos, um aumento de $22,22 \%$. A secreção do GH só é maior do que o observado na curva da $\mathrm{CC}$ aos 15 minutos e entre os 45 e os 60 minutos.

\section{Análise estatística}

Os resultados da análise estatística acham-se expressos no Quadro VI. 
QUADRO VI - Sujeito 6 - valores de $\boldsymbol{p}$ : C-teste, Mann-Whitney (U-teste), p<0,05

\begin{tabular}{|c|c|c|}
\hline \multirow[t]{2}{*}{ C-teste } & U-teste (00-120) & U-teste (45-120) \\
\hline & 9 pontos & 6 pontos \\
\hline
\end{tabular}

\begin{tabular}{lcccc} 
Hormônio & CC & CR & CCxCR & CCxCR \\
ACTH & 0,09 & $\mathbf{0 , 0 0}$ & $>0,9999$ & 0,1082 \\
Cortisol & $\mathbf{0 , 0 0}$ & $\mathbf{0 , 0 0}$ & $<\mathbf{0 , 0 0 0 1}$ & 0,0651 \\
Adrenalina & $\mathbf{0 , 0 4}$ & 0,11 & 0,1993 & $\mathbf{0 , 0 0 4 3}$ \\
Prolactina & 0,44 & $\mathbf{0 , 0 0}$ & $<\mathbf{0 , 0 0 0 1}$ & $\mathbf{0 , 0 0 4 3}$ \\
TSH & 0,15 & $\mathbf{0 , 0 1}$ & $<\mathbf{0 , 0 0 0 1}$ & 0,5200 \\
GH & $\mathbf{0 , 0 1}$ & $\mathbf{0 , 0 0}$ & $\mathbf{0 , 0 6 9 0}$ & 0,7477 \\
\hline
\end{tabular}

Em negrito, os resultados estatisticamente significativos.

00-120 - (minutos) intervalo de valores utilizados para a análise estatística 45-120 - (minutos) intervalo de valores utilizados para a análise estatística 
O passado existe na memória. O futuro, nas possibilidades.

Tudo o que temos é o aqui e o agora, sempre mutáveis e transitórios.

5. DISCUSSÃO 


\section{Discussão}

Os resultados comuns observados entre os sujeitos, sua relação com os sentimentos, emoções e sensações vivenciados durante a Rec-Mem, assim como as relações entre os diferentes hormônios serão discutidas no item 5.2. "Discussão Geral".

\subsection{Discussão Individual}

Todos os sujeitos são do cronotipo matutino (Tabela VII). Portanto, podem ser minimizadas as possíveis diferenças de ritmos de secreção hormonal como fatores de interferência nas respostas observadas.

A análise e a discussão dos resultados obtidos será feita de duas maneiras:

1. análise qualitativa

2. análise quantitativa

A análise qualitativa será feita através da simples observação dos perfis de secreção hormonal enquanto séries temporais em ambas as condições (CC e $\mathrm{CR}$ ), procurando se estabelecer explicação causal do fenômeno em função das características de sua manifestação com relação às diferentes fases dos procedimentos.

A análise quantitativa será feita através de testes estatísticos.

O método estatístico aplicável para séries temporais, especialmente desenhado para a avaliação de casos individuais (C-teste), permite a análise de cada curva de secreção hormonal de maneira isolada e independente, em termos do significado estatístico de sua tendência, medida por valores de $\boldsymbol{p}$. Tem grande valor na análise de séries temporais consecutivas, isto é, quando a condição controle é imediatamente seguida pela condição onde se introduz a variável a ser estudada. No presente estudo, dadas as características impostas pela técnica de Rec-Mem utilizada (TRV) houve um intervalo de 7 dias entre CC e CR para os sujeitos do sexo masculino e 5 semanas para os do sexo feminino, tornando impossível a comparação, por este método, entre a CC e a CR por não serem consecutivas, limitando-se 
somente à análise de cada condição individualmente. Assim, não será feita a comparação entre as curvas de secreção hormonal da CC e da CR por este método.

O teste de comparação de secreção hormonal como um todo (Mann-Whitney, U-teste), constitui um poderoso instrumento para comparar médias de secreção de cada hormônio em ambas as condições ( $\mathrm{CC}$ e $\mathrm{CR}$ ), porém desvinculadas de sua expressão temporal. A comparação de secreção hormonal será feita de duas formas: entre os instantes de 0 e 120 minutos para ambas as condições ( $\mathrm{CC}$ e $\mathrm{CR})$ e, dadas as características dos procedimentos da Rec-Mem, também será feita, quando aplicável, a comparação de secreção hormonal entre os instantes de 45 e 120 minutos, excluindo-se assim a influência dos procedimentos iniciais da técnica, isto é, Relaxamento e Aprofundamento que, em princípio, reduzem a secreção dos diferentes hormônios; com isto, serão comparados os valores de secreção hormonal com o sujeito em repouso (CC) e os observados exclusivamente durante a vivência e as fases finais dos procedimentos $(\mathrm{CR})$.

É possível, assim, pela análise qualitativa da sua expressão temporal, se estabelecer comparações e relações entre os perfis de secreção dos diversos hormônios em ambas as condições (CC e CR) em cada sujeito, assim como, quantitativamente, por meio da medida de tendências das séries temporais (C-teste) e pela comparação das médias de secreção hormonal (Mann-Whitney, U-teste).

Mesmo assim, devido à complexidade dos fenômenos envolvidos, suas particularidades e expressão funcional, as limitações impostas pela metodologia utilizada, a temporalidade das amostras obtidas e os testes estatísticos utilizados, com suas particularidades e limitações, nem sempre aquilo que se observa claramente pode ser medido.

Note-se que, em alguns dos resultados, os valores de $\boldsymbol{p}$ se situam não muito acima do limiar de significância estatística $(\mathrm{p}<0,05)$. Esse fato, aliado à expressão temporal dos fenômenos que, em alguns casos, indica a ocorrência de resposta ao estresse a despeito de 
ausência de significado estatístico, sugere fortemente que essas diferenças se devem às vivências experimentadas pelos sujeitos. A ausência de significado estatístico, se tomada como elemento isolado, pode, simplesmente, mascarar a sua existência.

Por isso, será a somação de ambas as formas de se avaliar os resultados que definirá a natureza dos fenômenos observados.

Devem também ser tomadas em conta as inevitáveis particularidades da metodologia utilizada. Vejamos:

A técnica utilizada (TRV) é uma técnica de psicoterapia concebida para a recuperação das memórias traumáticas; portanto, há que se ter o cuidado de não só recuperar tais memórias com o objetivo de se estudar as respostas hormonais, como também de preservar sua finalidade. Suas particularidades foram, portanto, preservadas, mesmo que possam eventualmente ter tido influência não só no resultado das dosagens como também na análise quantitativa dos fenômenos.

Uma dessas particularidades é o fundo musical, tal como definido em Material e Métodos, como parte integrante da técnica. Para reduzir o número de variáveis, estabeleceu-se que o mesmo fundo musical fosse também aplicado, indistintamente, na condição de repouso (CC) em todos os sujeitos; isto, porque tanto o estresse físico quanto o psicológico são influenciados pela música.

Uma revisão meta-analítica sobre o tema sugere que a música, isoladamente, assim como associada a técnicas de relaxamento assistido, é capaz de reduzir os níveis de alerta e de estresse em humanos, cuja resposta parece guardar relações com a idade, com o tipo de estresse, com o tipo de técnica de relaxamento utilizada e com a preferência musical do indivíduo (PELLETIER, 2004). A música clássica produz efeito significativo sobre a pressão arterial após o estresse quando comparada com outros tipos de música e com o silêncio (CHAFIN et al., 2004), o que sugere influências sobre a resposta simpática. Por outro lado, o 
cortisol salivar apresenta menor elevação diante do estresse, assim como o nível de percepção à dor é mais reduzido em pacientes que ouvem música quando submetidos a colonoscopia do que o grupo controle (UEDO et al., 2004). O cortisol salivar aumenta durante o estresse psicológico, fato que não se apresenta na presença de música (KHALFA et al., 2003). A resposta da testosterona à música apresenta dimorfismo sexual, diminuindo em homens e aumentando em mulheres. Nenhuma diferença quanto ao sexo foi observada quanto ao cortisol nas mesmas condições (FUKUI; YAMASHITA, 2003).

O estado de alerta ou de consciência do indivíduo é determinante para a resposta neuroendócrina ao estresse, pois a anestesia geral sob condição musical em procedimentos cirúrgicos não influencia a resposta ao estresse (MIGNEAULT et al., 2004). Os níveis de cortisol e a amplitude do seu ritmo circadiano se reduzem durante a exposição à música em técnicas de relaxamento, assim como a temperatura corporal (RIDER et al., 1985).

Assim, é possível que o fundo musical utilizado durante os procedimentos em ambas as condições $(\mathrm{CC}$ e $\mathrm{CR})$ possa ter tido influência sobre a resposta dos diferentes sujeitos, o que é particularmente importante na $\mathrm{CR}$, podendo ter contribuído para menores níveis de secreção hormonal, influenciando negativamente os resultados dos testes de comparação de secreção hormonal como um todo (Mann-Whitney, U-teste).

Por outro lado, a técnica empregada para a recuperação de memórias traumáticas se divide em três fases gerais distintas, conforme exposto anteriormente:

1. Relaxamento (Relaxamento e Aprofundamento),

2. Vivência (Momento Mais Traumático, Decisão e Redecisão),

3. Procedimentos Subseqüentes (Desprogramação e Reprogramação Positiva, Retorno e Finalização). Estes se destinam não só à re-estruturação e re-significação dos elementos da vivência, como também a recondução à condição inicial de vigília. 
As fases de Relaxamento e de Aprofundamento são exercidas com a finalidade de se reduzir ao mínimo os estímulos sensoriais que agem em contraponto com a emergência dos conteúdos psíquicos. Elas têm, assim, aliadas à influência do fundo musical, em princípio, o efeito de reduzir a secreção hormonal, fato que se repete nas fases finais da técnica.

É somente durante a vivência que ocorrem os estímulos que podem exercer ação estimuladora sobre a secreção hormonal.

Por isso, tomando o sujeito em sua condição de repouso (CC) em relação a essas três fases distintas, está se comparando, na verdade, a CC com três situações fisiologicamente diferentes nas quais somente a vivência é a variável estudada. Como são de naturezas diferentes (primeira e terceira fases, como inibição da secreção hormonal, e segunda fase, de estímulo), é bem possível que esse fato tenha tido influência sobre os resultados estatísticos, particularmente nos métodos de comparação de secreção hormonal como um todo.

Outro fator complicador da análise dos resultados é representado pelo tempo de latência de resposta hormonal, significando que níveis hormonais observados numa determinada fase dos procedimentos podem bem representar a resposta decorrente de um estímulo ocorrido numa fase anterior. Por exemplo, entre o início da secreção do ACTH e a resposta do córtex suprarenal medida pela secreção de cortisol existe um tempo de latência de cerca de quinze a trinta minutos (MILUK-KOLASA et al., 1994). Este fato, aliado às características temporais das coletas (a cada quinze minutos) impossibilita o estabelecimento de relações temporais mais precisas dos fenômenos, fato agravado pelo pequeno número de dosagens obtidas em cada fase (três para as fases de Relaxamento e Aprofundamento, três para a fase de Vivência e três para as fases finais dos procedimentos). Por isso, em alguns casos, foram desconsiderados os valores referentes a estas fases para a comparação de médias de secreção hormonal, restringido-se o cálculo aos valores obtidos durante a vivência e fases subseqüentes. 
Portanto, as curvas de tempo e resposta apresentam características particulares que dificultam cálculos estatísticos, ressaltando-se assim o valor da análise qualitativa como um dos elementos de definição do que realmente tenha ocorrido.

5.1.1. SUJEITO 1 - CMM, 49 anos, sexo feminino.

As respostas observadas nesse sujeito estão representadas pela Tabela I e pelas Figuras 1, 2 e 3 de A a F.

5.1.1.1. ACTH (Figuras 1-A, 2-A e 3-A): a despeito do fato do C-teste indicar ausência de significado estatístico das tendências das curvas da $\mathrm{CC}$ e na $\mathrm{CR}$ ( $\mathrm{p}=0,24$ e $\mathrm{p}=0,22$ respectivamente, para um $\mathrm{p}<0,05$ ), sugerindo que as flutuações observadas sejam devidas ao acaso, a diferença das médias de secreção hormonal em ambas as condições (CC e CR) para os valores entre 0 e 120 minutos é significativa (Mann-Whitney, U-teste, $p<0,0015$ ) (Quadro I).

São observados valores mais elevados na $\mathrm{CR}$ em relação à $\mathrm{CC}$ entre os -30 e os 15 minutos, sugerindo maior estresse da condição de chegada ao laboratório e/ou antecipatório aos procedimentos da CR. No entanto, as curvas de secreção hormonal rescalonadas exibidas na Figura 2-A mostram que as variações relativas de secreção de ACTH se situam em patamares diferentes, sugerindo que o nível geral de estresse devido aos procedimentos, a despeito do esclarecimento prévio prestado ao sujeito, foi mais intenso na $\mathrm{CC}$ do que na $\mathrm{CR}$; nesta, o sujeito já conhecia a natureza do experimento. A eficiência do relaxamento inicial da técnica contribuiu para a variação negativa de secreção de ACTH observado até os 15 minutos, quando se dá o início da variação positiva mais expressiva observada na CR.

$\mathrm{Na}$ CR, o fim do Aprofundamento só é atingido aos 40 minutos. No entanto, observase aumento da secreção hormonal já a partir dos 15 minutos, atingindo um valor máximo aos 30 minutos, um pouco acima dos limites superiores dos valores de referência para o ensaio (Figura 1-A), no fim do Relaxamento e início do Aprofundamento. $\mathrm{Na} \mathrm{CC}$ todos os valores 
flutuaram dentro destes limites. Tal fato é indicativo de estimulação hipofisária precoce, ou antecipatória, já que a vivência foi experimentada pelo sujeito somente entre os 40 minutos e os 75 minutos, durante os quais a curva de secreção é descendente. Esse segmento descendente, apesar de se manter em valores mais elevados em relação aos valores da curva da $\mathrm{CC}$, evolui para o retorno progressivo aos valores observados na CC. Essa queda progressiva da curva da CR sugere a somatória da atenuação fisiológica ao estímulo estressor com os procedimentos destinados à recondução do paciente à condição de vigília.

Houve, assim, estímulo para a secreção do ACTH que antecedeu à vivência, possivelmente como resultado do início da emergência dos conteúdos que a compuseram.

5.1.1.2. Cortisol (Figuras 1-B, 2-B e 3-B): igualmente, enquanto o C-teste indica que as flutuações hormonais observadas em ambas as condições não são estatisticamente significativas $(\mathrm{p}=0,13$ para a $\mathrm{CC}$ e $\mathrm{p}=0,59$ para a $\mathrm{CR}$ ), a diferença das médias de secreção hormonal em ambas as condições (CC e CR) para os valores entre 0 e 120 minutos é significativa (U-teste, $\mathrm{p}<0,0106)$ (Quadro I).

O repouso de 30 minutos é suficiente para conduzir o sujeito de uma situação de estresse de chegada ao laboratório a uma condição de repouso de secreção hormonal tanto na CC quanto na $\mathrm{CR}$.

O perfil da curva da CC sugere o ritmo circadiano de secreção do cortisol. A curva da CR segue inicialmente o mesmo perfil, para apresentar aumento de produção hormonal entre os 45 e os 60 minutos, com atraso fisiológico de 30 minutos em relação à curva do ACTH (Figura 1-A), indicando estimulação do eixo HPA (MILUK-KOLASA et al., 1994).

Os valores observados na $\mathrm{CR}$ podem ter sido atenuados pelo conhecimento prévio do sujeito sobre a natureza do experimento. A secreção hormonal decresce a partir do fim da vivência, aos 75 minutos e, apesar de se manter em valores mais elevados em relação aos valores da CC, finalmente atinge valor indistinguível do observado na curva da CC aos 120 
minutos. Tal resultado sugere, igualmente, a somatória da influência dos procedimentos destinados a reduzir o estresse gerado pela vivência, com o decréscimo esperado pela manifestação do ritmo circadiano do cortisol, mais a extinção do efeito estressor sobre a secreção hormonal.

Os resultados estão concordantes com a secreção do ACTH e indicam resposta do eixo HPA à vivência.

5.1.1.3. Adrenalina (figuras $1-\mathrm{C}, 2-\mathrm{C}$ e $3-\mathrm{C}$ ): o $\mathrm{C}$-teste indica que a flutuação levemente ascendente da curva da $\mathrm{CC}$ é estatisticamente significativa $(\mathrm{p}=0,03)$ enquanto que a flutuação observada na $\mathrm{CR}$ não é estatisticamente significativa $(\mathrm{p}=0,24)$. Concordantemente, a diferença de secreção hormonal em ambas as condições (CC e CR) para os valores entre 0 e 120 minutos não é significativa (Mann-Whitney, U-teste, $p=0$,2888) (Quadro I), embora tenha sido observada grande elevação da secreção de adrenalina a partir dos 45 minutos na CR. Mesmo se testando somente os valores observados a partir dos 45 minutos em ambas as condições (CC e CR), não se observa significância estatística (Mann-Whitney, U-teste, $\mathrm{p}=0,5887)$.

A análise estatística da diferença de secreção hormonal mascara a manifestação temporal do fenômeno, claramente exibida nas Figuras 1-C, 2-C e 3-C, assim como a influência particular de cada fase da técnica (a curva é decrescente durante as fases de Relaxamento e Aprofundamento, fortemente ascendente durante a vivência e descendente durante as fases finais da técnica). Ao observá-lo em função do tempo, no entanto, vemos que a curva da $\mathrm{CR}$ apresenta, a partir dos 45 minutos, súbito e intenso aumento, atingindo um valor máximo aos 60 minutos $(263,63 \%$ em relação ao instante 0 e $661,9 \%$ em relação aos 45 minutos) ultrapassando os valores do coeficiente de variação intra-ensaio, o limite superior dos valores de referência para o ensaio e em muito o valor do instante de chegada ao 
laboratório (estresse de chegada). Em nenhum instante durante a CC se observa fenômeno comparável.

Essa elevação pode também representar o efeito da elevação do fluxo do cortisol através do sistema porta córtico-medular da suprarenal, aumentando a síntese de adrenalina pela estimulação da fenil-etanolamina-n-metil-transferase (WURTMAN, 2002). Por outro lado, a elevação da secreção de adrenalina parece se associar com o tipo de trauma sofrido pela paciente, evocado pela RM entre os 40 minutos e os 75 minutos, com o Momento Mais Traumático que ocorre entre os 45 e os 60 minutos, sendo caracterizado por raiva intensa, irritação (agressão física e verbal), medo, solidão, frustração, sensação de perda (do filho, para o marido) e forte sentimento de rejeição: agressões físicas e psicológicas intensas e repetidas, que podem sugerir uma resposta do tipo luta-ou-fuga. Subseqüentemente, a secreção de adrenalina cai para valores mais baixos do que os valores observados na CC aos 105 e 120 minutos (queda de 68,18 \% em relação ao instante 0 e a menos de $10 \%$ dos valores observados aos 60 minutos). Essa queda no final dos procedimentos da CR indica a importância dos procedimentos destinados a reduzir o estresse gerado pela vivência, associada à extinção da resposta autonômica ao estresse.

Chama a atenção o fato de que a adrenalina apresenta aumento com atraso de 30 minutos em relação ao ACTH, quando seria de se esperar o oposto: como resposta ao estresse, ocorre rápida ativação autonômica seguida por excitação mais lenta do eixo HPA (WOLF, 2003), o que sugere desacoplamento temporal entre respostas autonômicas e neuroendócrinas. Essa inversão pode ser devida a estímulo temporalmente diferenciado dos neurônios do sistema CRH, pois o disparo de neurônios extra-hipotalâmicos que expressam o CRH pode não ser concomitante ao das células neurosecretoras do hipotálamo (GRAEFF, 2003) e a própria expressão gênica do CRH nos neurônios que constituem a via de saída do sistema hipocampo-amigdalóide (núcleo central da amigdala e no núcleo instersticial da stria 
terminalis) parece estar temporalmente dissociada da observada no núcleo paraventricular (SCHULKIN et al., 1998).

Houve, assim, estímulo de secreção de adrenalina pela medula suprarenal em decorrência dos conteúdos experimentados pelo sujeito durante a vivência.

5.1.1.4. Prolactina (Figuras 1-D, 2-D e 3-D): as flutuações observadas nas curvas de secreção hormonal medidas pelo $C$-teste não são estatisticamente significativas $(p=0,31$ na $\mathrm{CC}$ e $\mathrm{p}=0,20$ na $\mathrm{CR}$ ). A diferença das médias de secreção hormonal em ambas as condições (CC e CR) para os valores entre 0 e 120 minutos também não é significativa (Mann-Whitney, U-teste, $\mathrm{p}=0,3865$ ) (Quadro I). Para os valores entre 45 e 120 minutos, também não é significativa (Mann-Whitney, U-teste, $\mathrm{p}=0,1320$ ).

Nota-se que as curvas da CC e da CR são quase indistinguíveis do instante de chegada ao laboratório até os 30 minutos dos procedimentos. A curva da CC apresenta inexplicável elevação aos 45 minutos, dado que o repouso foi obtido de maneira adequada. É possível que represente a expressão de pulsatilidade espontânea de secreção hormonal. A curva da CR prossegue em queda até os 45 minutos, o que sugere o efeito dos procedimentos de Relaxamento e Aprofundamento sobre a secreção hormonal.

Coincidente com a vivência ocorre aumento da secreção hormonal de 262,96\% entre os 45 e os 75 minutos, ultrapassando sensivelmente não só o coeficiente de variação intraensaio, como também o limite superior dos valores de referência para o ensaio, expressando forte variação positiva da secreção hormonal (Figura 2-D), indicando tratar-se de resposta de secreção de prolactina aos seus conteúdos e ao estresse gerado por eles. Em nenhum momento durante a CC se observa fenômeno comparável. Observe-se que o valor aos 120 minutos, apesar do estresse que o antecedeu, é indistinguível do observado na CC, numa queda de $61,22 \%$ entre os 75 e os 120 minutos, mantendo-se, no entanto, em valores superiores aos dos 
observados na CC, o que sugere tratar-se da somatória da extinção da resposta de secreção hormonal ao estresse com os efeitos dos procedimentos finais da técnica.

A importância da qualidade emocional da vivência revela-se pelo fato de que o sujeito experimentou raiva e humilhação intensas que parecem ser determinantes da resposta hormonal (SOBRINHO, 2003). A disputa pelo filho com o ex-marido poderia estar teoricamente associada a aspectos psiconeuroendócrinos relativos à maternidade; no entanto, a indução de uma situação imaginária de amamentação sob estado hipnoidal não foi capaz de provocar respostas na secreção de prolactina (SOBRINHO, 2003).

Os dados indicam resposta da prolactina aos conteúdos da vivência.

5.1.1.5. TSH (Figuras 1-E , 2-E e 3-E): as tendências das curvas de secreção hormonal em ambas as condições não são estatisticamente significativas (C-teste, $p=0,07$ para a CC e p =0,60 para CR), enquanto que a comparação das médias de secreção hormonal em ambas as condições (CC e CR) para os valores entre 0 e 120 minutos é significativa (Mann-Whitney, U-teste, $\mathrm{p}=0,0305)$ (Quadro I).

A curva da CC apresenta um padrão de variação negativa homogênea (Figura 2-E), com exceção de um acréscimo positivo aos 105 minutos, possivelmente representando a manifestação de um pulso isolado de liberação hormonal; sua tendência decrescente é significativa e expressa a redução circadiana de secreção hormonal. A curva da CR mostra valores iniciais mais baixos do que os da CC (menor nível de estresse de chegada ao laboratório) e, a seguir, apresenta um perfil oscilante com tendência de variação positiva (Figura 2-E), com valores mais elevados de secreção hormonal, sem exibir a expressão circadiana observada na curva da CC: algo impediu que ela se manifestasse. A secreção hormonal apresenta oscilações positivas aos 45,75 e 105 minutos, possivelmente devidas à coincidência dos instantes da coleta com picos espontâneos de secreção hormonal, mas é claramente ascendente a partir do início da vivência: entre os 30 (fim do Aprofundamento) e 
os 105 minutos, ocorre uma elevação de 150 \% na secreção hormonal. Somente aos 105 minutos, iniciaram-se as fases de Retorno e de Finalização, com a devolução do sujeito ao estado normal de vigília aos 120 minutos.

Tal resultado indica estímulo da secreção do TSH hormonal devida aos conteúdos da vivência.

5.1.1.6. GH (Figuras $1-\mathrm{F}, 2-\mathrm{F}, 3-\mathrm{F})$ : a tendência decrescente de secreção de GH na CC é estatisticamente signficativa (C-teste, $\mathrm{p}=0,01$ ) representando a influência repouso obtido pelo sujeito após a condição de estresse de chegada ao laboratório. $\mathrm{Na} \mathrm{CR}$, o valor de $\boldsymbol{p}$ se situa um pouco acima do limite de significância estatística $(p=0,06)$ : a tendência da curva na CR não é estatisticamente significativa, com um valor de $\boldsymbol{p}$ levemente acima do limite da significância estatística. A diferença entre as médias de secreção hormonal em ambas as condições (CC e CR) para os valores entre 0 e 120 minutos não é significativa (MannWhitney, U-teste, $\mathrm{p}=0,8941$ ) (Quadro I).

Os valores de secreção do $\mathrm{GH}$ aos -30 minutos $\mathrm{CC}$ é sensivelmente mais elevado dos que os da CR, e possivelmente são devidos aos ao estresse de chegada ao laboratório e efeitos da movimentação física sobre a secreção hormonal. Após o repouso, tais valores apresentam clara tendência descendente, concordante com os resultados do C-teste.

As curvas de secreção hormonal na CC e da CR são praticamente indistinguíveis até o final dos procedimentos (Figura 1-F), mas se situam em patamares de variação hormonal diferentes, se bem que muito próximos (Figura 2-F). As variações relativas decrescentes de secreção de GH na CC apresentam-se com uma intensidade maior do que a observada na CR. Nesta condição, a variação relativa é negativa durante as fases de Relaxamento e Aprofundamente, havendo uma variação positiva a partir do início da vivência (dos 45 aos 75 minutos) após o que novamente decresce, ao longo das fases finais da técnica. Isto significa que algo impediu que a variação de secreção de $\mathrm{GH}$ na $\mathrm{CR}$ fosse igual à da $\mathrm{CC}$, tornando a 
queda não estatisticamente significativa no C-teste. Este algo pode representar a influência do conteúdo emocional da vivência sobre a secreção do GH. Com efeito, se abstrairmos os instantes de 0,15 e 30 minutos em ambas as condições (para a CR, os instantes relativos aos processos de Relaxamento e Aprofundamento) e submeter os valores restantes (45, 60, 75, 90 105 e 120 minutos) em ambas as condições (CC e CR), exatamente aqueles que se referem à vivência e fases subseqüentes, à análise quantitativa, obteremos valores estatisticamente significativos (Mann-Whitney, U-teste, $\mathrm{p}=0,0022$ ), demonstrando ter existido maior secreção de GH durante estes instantes na CR do que na CC.

Os dados obtidos, assim, indicam resposta de secreção do GH à vivência.

\subsubsection{Resumo:}

Os resultados observados nesse sujeito indicam resposta do eixo HPA, da prolactina, do TSH, do GH e da medula suprarenal aos conteúdos da vivência.

5.1.2. SUJEITO 2 - APVR, 31 anos, sexo feminino.

As respostas observadas nesse sujeito estão representadas pela Tabela II pelas Figuras de 4,5 e 6 , de A a F.

5.1.2.1. ACTH (Figuras 4-A, 5-A e 6-A): as tendências das curvas em ambas as condições são estatisticamentes significativas (C-teste, $p=0,00$ para a $\mathrm{CC}$ e $\mathrm{p}=0,03$ para a $\mathrm{CR}$ ). A diferença de secreção hormonal em ambas as condições (CC e CR) para os valores entre 0 e 120 minutos é significativa (Mann-Whitney, U-teste, $\mathrm{p}<0,0001$ (Quadro II). Concordantemente, se excluirmos os valores de secreção hormonal relativos aos instantes 0 , 15 e 30 minutos em ambas as condições (CC, repouso; CR, Aprofundamento e Relaxamento) e testarmos estatisticamente os valores remanescentes em ambas as condições (CC e CR) relativos à vivência e fases subseqüentes, encontraremos resultados igualmente significativos (Mann-Whitney, U-teste, $\mathrm{p}=0,0249$ ). 
Observa-se na curva da CC, um perfil de secreção homogêneo e ascendente, fato não concordante com condição de repouso. Com efeito, nessa condição, o sujeito se emocionou com lembranças sobre as quais não conseguiu se recordar ao voltar ao estado de vigília. Esta é a explicação possível para o perfil da curva da $\mathrm{CC}$, o que sugere estímulo da secreção adenohipofisária de ACTH às memórias espontaneamente evocadas e depois esquecidas.

O perfil de secreção na curva da CR é semelhante, homogeneamente ascendente, atingindo um máximo aos 60 minutos, com a diferença de que nesta condição houve o fenômeno de Rec-Mem. Segue-se queda discreta ao passar pelas fases de Decisão, Redecisão, Desprogramação, Programação Positiva, Retorno e Finalização. Nas curvas rescalonadas de secreção hormonal (Figura 5-A) observa-se melhor o fenômeno com intensa variação positiva de secreção hormonal a partir do início da Rec-Mem. Como este perfil ascendente é estatisticamente significativo, tudo indica que seja devido a estimulação de secreção adenohipofisária de ACTH relativo aos conteúdos da vivência, particularmente quando comparado ao perfil observado durante a CC, onde ocorreu emergência espontânea de memórias emocionais subseqüentemente esquecidas.

Se compararmos o perfil de secreção do ACTH na CR em relação ao perfil de secreção do cortisol na mesma condição (Figura 4-B), veremos que os dados não são indicativos de estimulação do eixo HPA, apesar da oscilação positiva observada entre os 45 minutos e 75 minutos, em plena vivência, de natureza intensamente traumática, com sinais clínicos de resposta autonômica (taquicardia aos 38 e aos 48 minutos). $\mathrm{O}$ aspecto ascendente da curva do cortisol a partir dos 90 minutos (melhor visto na Figura 5-B) é sugestivo de reação do córtex suprarenal a esta onda positiva de secreção do ACTH, ocorrendo com o atraso fisiológico esperado (MILUK-KOLASA et al., 1994).

Por outro lado, é comum observar-se a inibição da resposta do eixo HPA no transtorno do estresse pós-traumático (TEPT) que se manifesta por baixa secreção de cortisol urinário, 
assim como plasmático, em pacientes submetidos pela segunda vez ao mesmo tipo de trauma (YEHUDA et al., 1995; RESNIK et al., 1995), associado à hiperativação da resposta autonômica (vide discussão da adrenalina). Considera-se que essa inibição se deva à exacerbação da retroalimentação negativa do cortisol devido a receptores hipersensíveis situados no hipocampo, no hipotálamo e na hipófise (GRAEFF, 2003), o que parece estar associada ao aumento da vulnerabilidade ao desenvolvimento do TEPT. A redução do volume hipocampal observada na TEPT tem sido relacionada com as anormalidades da resposta do eixo HPA encontradas nesse transtorno. Os presentes achados experimentais, sugerindo resposta do eixo HPA semelhante ao que se observa no TEPT, levanta especulações cabíveis sobre as relações entre o estado anátomo-funcional de estruturas neuroendócrinas relacionadas ao eixo HPA, à pré-disposição ao TEPT, à natureza das memórias traumáticas recuperadas e, eventualmente, ao tema que esteja sendo tratado durante um processo de RecMem.

O sujeito é portador de Fobia Social (SCID/DSM-IV (300.23). A vivência de uma situação traumática imaginária intencionalmente induzida foi capaz de produzir respostas autonômicas, mas não neuro-endócrinas (CAVINI-FERREIRA et al., 2002; CAVINIFERREIRA et al, 2003). Tudo parece indicar, portanto, que não importa o contexto da vivência, mas sim a natureza de seu conteúdo emocional. Respostas neuroendócrinas e autonômicas nessas situações levantam questões a serem respondidas por futuros projetos de pesquisa.

Os resultados indicam resposta de secreção do ACTH aos conteúdos da vivência.

5.1.2.2. Cortisol (Figuras 4-B, 5-B e 6-B): a tendência decrescente das curvas de secreção do cortisol tanto na CC quanto na CR são estatisticamente significativas (C-teste, $\mathrm{p}=0,00$ na $\mathrm{CC}$ e $\mathrm{p}=0,00$ na $\mathrm{CR}$ ). Não fora o aspecto ascendente e significativo da curva de secreção do ACTH em ambas as condições, seria possível se admitir a manifestação 
circadiana da secreção do cortisol. Valem, portanto, as considerações feitas anteriormente sobre as características de secreção do cortisol no TEPT (YEHUDA et al., 1995; RESNIK et al., 1995). A diferença de secreção hormonal em ambas as condições (CC e CR) para os valores entre 0 e 120 minutos é significativa (Mann-Whitney, U-teste, $\mathrm{p}<0,0001$ ) (Quadro II), no entanto claramente devida ao fato de que a curva de secreção hormonal na CC se situa num patamar mais elevado do que na CR. O rescalonamento das curvas de secreção hormonal (Figura 5-B) indica que a variação de secreção hormonal em relação ao instante de chegada se equivale em ambas as condições, com exceção do segmento final ascendente na CR.

A análise temporal do fenômeno mostra que as curvas da $\mathrm{CC}$ e da $\mathrm{CR}$ não guardam relação com as curvas do $\mathrm{ACTH}$, a não ser o segmento final ascendente da curva do cortisol na $\mathrm{CC}$, como resposta ao pico máximo de $\mathrm{ACTH}$ atingido aos 60 minutos. Na verdade, a curva do cortisol na CC se situa em valores significativamente mais elevados que os da curva da $\mathrm{CR}$ (na curva da CC, observam-se os valores iniciais entre -30 e 30 minutos acima dos limites dos valores de referência para o ensaio, indicando estresse de chegada ao laboratório, a despeito de nenhum fato significativo tenha sido relatado pelo sujeito que se relacionasse causalmente com estes valores), possivelmente representando o estado funcional do sujeito numa condição estudada cinco semanas antes que, num outro patamar, se repete na CR. .

No estresse crônico se observam níveis basais de cortisol elevados, com baixa resposta a estressores agudos. O fenômeno da habituação, com variabilidade de respostas individuais, poderia ser invocado caso o sujeito apresentasse história compatível com esta hipótese (WÜST et al., 2005) e se houvesse fenômeno semelhante na curva da CC do ACTH.

Vale a pena ressaltar o segmento ascendente da curva da CR, entre 90 e 120 minutos, sugerindo reação do córtex supra-renal ao valor elevado da curva da CR do ACTH observado entre os 45 e 90 minutos, representando atraso fisiológico da resposta adrenocortical, já que a ocorrência do Momento Mais Traumático ocorreu entre os 38 e 75 minutos, o que se insere 
dentro da relação temporal entre o estímulo estressor e a resposta do cortisol (MILUKKOLASA et al., 1994). Este fato, isoladamente, sugere, mas não é conclusivo, resposta do córtex suprarenal aos conteúdos da vivência,

5.1.2.3. Adrenalina (Figuras 4-C, 5-C e 6-C): as flutuações de secreção hormonal na $\mathrm{CC}$ não são estatisticamente significativas ( $\mathrm{C}$-teste, $\mathrm{p}=0,54)$, enquanto que na $\mathrm{CR}$, são estatisticamente significativas (C-teste, $\mathrm{p}=0,01$ ). Apesar disso, a diferença de secreção hormonal em ambas as condições (CC e CR) para os valores entre 0 e 120 minutos não é significativa (Mann-Whitney, U-teste, $\mathrm{p}=0,1710$ ) (Quadro II), mesmo levando-se em consideração apenas os pontos relativos à vivência e procedimentos subseqüentes, ou seja, os tempos entre 45 e 120 minutos (Mann-Whitney, U-teste, $\mathrm{p}=0,4704$ ).

A despeito destes valores de $\boldsymbol{p}$, a expressão temporal fenômeno na $\mathrm{CR}$ mostra aumento rápido e intenso da secreção de adrenalina a partir dos 30 minutos, atingindo o seu valor máximo aos 90 minutos (tangenciando o limite superior dos valores de referência para o ensaio), sensivelmente mais elevado do que o observado no mesmo instante na $\mathrm{CC}$, e ocorrendo ao longo da vivência. O Momento Mais Traumático ocorreu entre os 38 e os 75 minutos, com sinais objetivos de ativação autonômica, representada por taquicardias. Esta diferença significativa se mantém aos 105 minutos, caindo para valores ainda mais elevados do que os da $\mathrm{CC}$ aos 120 minutos.

As variações relativas de secreção hormonal na $\mathrm{CR}$ visualizadas na Figura 5-C conferem significado estatístico ao fenômeno de natureza claramente ascendente a partir dos 30-45 minutos (C-teste, $\mathrm{p}=0,01$ ), em plena vivência, o que indica resposta da medula suprarenal aos seus conteúdos.

Os dados também indicam inversão temporal da ativação dos neurônios produtores de CRH responsáveis pela estimulação autonômica e do eixo HPA (GRAEFF, 2003; SCHULKIN et al.,1998; WOLF, 2003). 
5.1.2.4. Prolactina (Figuras 4-D, 5-D e 6-D): em ambas as condições (CC e CR) a tendência das curvas de secreção de PRL é descendente. Na CC esta tendência revela um valor de $\boldsymbol{p}$ no limite da significância estatística (C-teste, $\mathrm{p}=0,05$ ), mas na $\mathrm{CR}$ é estatisticamente significativa (C-teste, $\mathrm{p}=0,00)$ e, apesar de a diferença de secreção hormonal em ambas as condições (CC e CR) para os valores entre 0 e 120 minutos ser significativa (Mann-Whitney, U-teste, $\mathrm{p}<0,0001$ ) (Quadro II), exprime, provavelmente, atenuação fisiológica ao estresse de chegada ou expressão de ritmo circadiano de secreção hormonal.

A variação relativa de secreção hormonal em ambas as condições é mais bem visualizada na Figura 5-D, onde se observa que na CC o nível de atenuação foi mais lento do que na $\mathrm{CR}$, provavelmente expressando o nível geral de estresse experimentado na CC, a despeito dos esclarecimentos prévios prestados ao sujeito. O nível de atenuação mais rápido observado na CR provavelmente expressa o fato de que o sujeito já conhecia a natureza do experimento.

Outra condição que poderia teoricamente explicar as ausências de respostas da prolactina (assim como as do cortisol) ao estresse experimentado pelo sujeito seria o hipotireoidismo, pois os hormônios da tireóide são necessários para que haja resposta apropriada da prolactina e da corticosterona ao estresse (RODRIGUEZ et al., 2003). No entanto, não existiram elementos clínicos prévios ao experimento que pudessem fazer supor a sua presença.

$\mathrm{O}$ aspecto qualitativo emocional do estresse experimentado durante a Rec-Mem (raiva e humilhação) parece ser crítico para o estímulo de secreção hormonal (SOBRINHO, 2003). Apesar de o sujeito ter experimentado situação sugestiva de humilhação, não houve manifestação de raiva.

Portanto, os dados obtidos não indicam resposta de prolactina em função da vivência experimentada pelo sujeito. 
5.1.2.5. TSH (Figuras 4-E, 5-E e 6-E): as tendências exibidas pelas curvas de secreção hormonal são estatisticamente significativas (C-teste, $p=0,00$ para a $C C, p=0,01$ para a $C R$ ). A diferença de secreção hormonal entre CC e CR para os valores entre 0 e 120 minutos é significativa (Mann-Whitney, U-teste, $\mathrm{p}=0,0003$ ) (Quadro II).

As curvas de secreção de TSH em ambas as condições apresentam um perfil descendente a partir do instante de chegada ao laboratório, tornando-se indistinguíveis a partir dos 60 minutos e apresentando estabilização, a partir dos 75 minutos até o final dos procedimentos. Entre os instantes de chegada ao laboratório até os 90 minutos, a curva de secreção de TSH na CC se situa em valores um pouco mais elevados do que os observados na CR. Tudo indica, em ambas as curvas, a expressão do perfil circadiano de secreção do TSH. A Figura 5-E revela a variação relativa de secreção hormonal em ambas as condições, mostrando atenuação mais rápida na $\mathrm{CC}$ do que na $\mathrm{CR}$; ambas, no entanto, são estatisticamente significativas e provavelmente expressam a secreção circadiana do TSH.

Uma possível especulação sobre a ausência de resposta do TSH à vivência se baseia no que se observa no TEPT, onde ocorre aumento de T3 live, T4 total e TBG, sem alterações do T4 livre e do TSH. Como o T3 livre tem grande potência biológica, a ausência de resposta do TSH ao estresse talvez tenha se devido à retroalimentação negativa exercida pelo T3 livre sobre a adenohipófise (WANG; MASON, 1999).

Não houve, assim, resposta do TSH aos conteúdos da vivência.

5.1.2.6. GH (Figuras 4-F, 5-F 6-F): a análise das tendências das curvas de secreção de GH mostra que elas são estatisticamente significativas ( $C$-teste, $p=0,00$ para a CC e p=0,01 para a $\mathrm{CR}$ ), no entanto com significado diferente, pois enquanto na $\mathrm{CC}$ o perfil de secreção é descendente a partir de valores de chegada ao laboratório situados acima dos valores de referência para o ensaio, expressando progressivo repouso atingido pelo sujeito após o estresse de chegada, na CR é constante a partir da condição de chegada, no limite inferir dos 
valores de referência para o ensaio, ao que se soma a influência do relaxamento e do aprofundamento sobre a secreção hormonal, é ascendente a partir dos 45 minutos. Aqui, o mascaramento estatístico sobre a natureza temporal da resposta se manifesta com clareza: a diferença das médias de secreção hormonal em ambas as condições (CC e CR) para os valores entre 0 e 120 minutos não é significativa (Mann-Whitney, U-teste, p = 0,07962) (Quadro II). No entanto, se excluirmos os valores entre 0 e 30 minutos (repouso na CC, e Relaxamento e Aprofundamento na CR), e testarmos os valores subseqüentes em ambas as condições (CC e CR), obteremos resultados estatisticamente significativos (Mann-Whitney, U-teste, $\mathrm{p}=0,0022)$.

Os estresses físicos, metabólicos e psicológicos, são potentes estimuladores da secreção do $\mathrm{GH}$, havendo diferenças sexuais no perfil de pulsatilidade do GH, onde homens apresentam picos mais altos e mais freqüentes, com níveis basais mais baixos, e as mulheres apresentam picos mais altos e menos freqüentes, como níveis basais mais altos (GIUSTINA; VELDHUIS, 1998), além da manifestação de picos espontâneos de GH que ocorrem durante o dia, ao acaso, sendo, no entanto, mais freqüentes durante as primeiras fases do sono, onde se manifestam de maneira uniforme (WINER et al., 1990). A partir dos 45 minutos ocorre enorme aumento de secreção do GH temporalmente associado à vivência, ultrapassando os limites superiores dos valores de referência para o ensaio. Os dados observados também sugerem a existência de uma possível relação com o perfil de secreção da adrenalina: os receptores $\alpha-2$ e $\beta$-2 adrenérgicos são estimuladores putativos da secreção $\mathrm{GH}$ e de somatostatina respectivamente (GIUSTINA; VELDHUIS, 1998). Sob estresse, tanto GHRH quanto somatostatina são lançados na circulação porta-hipofisária, sendo a secreção final do GH o resultado "líquido" deste balanço (CATALDI et al., 1994). Neste sujeito, a liberação do GH se dá a partir dos 45 minutos, com rápido incremento a partir dos 60 minutos, coincidente com o rápido aumento de secreção de adrenalina, que começa a partir dos 30 minutos. 
A Figura 5-F revela com clareza as variações relativas de secreção hormonal.

Dado que tanto na $\mathrm{CC}$ quanto na $\mathrm{CR}$ o sujeito permaneceu em decúbito dorsal, em repouso, podem-se excluir os efeitos de exercício físico como fatores estimuladores da resposta do GH a partir dos 45 minutos. Como o TSH se manteve sem alterações significativas, pode-se, também, excluir ação estimuladora do TRH sobre a secreção do GH, observada em experimentos e em condições fisiopatológicas em seres humanos (GIUSTINA; VELDHUIS, 1998).

A rigor, não se pode excluir a hipótese de que esta elevação possa representar pulso espontâneo de liberação do GH.

No entanto, a pulsatilidade que caracteriza a secreção do $\mathrm{GH}$, apesar de ocorrer ao acaso durante o dia, é observada principalmente durante o sono (WINER et al., 1990). Durante o dia, podem ocorrer um ou dois picos agudos de secreção de GH normalmente cerca de 3 a 4 horas após as refeições. Se adicionarmos a estas observações a ocorrência do mesmo perfil de secreção nos sujeitos 3 e 5, sempre durante a CR, com relação a aspectos fortemente emocionais que caracterizaram as diferentes vivências, esta hipótese fica mais distante, indicando fortemente que a elevação da secreção do GH observada durante a CR tenha representado, na verdade, resposta aos conteúdos da vivência. 


\subsubsection{Resumo}

Os dados observados neste sujeito indicam estimulo do eixo HPA, da medula suprarenal e do GH em associação com a vivência.

5.1.3. SUJEITO 3 - RCM, 46 anos, sexo feminino.

As respostas observadas no sujeito em questão estão representadas pela Tabela III e pelas Figuras 7, 8 e 9 de A a F.

5.1.3.1. ACTH (figuras 7-A, 8-A e 9-A): enquanto que na CC o perfil de secreção de $\mathrm{ACTH}$ não é estatisticamente significativo (C-teste, $\mathrm{p}=0,31$ ), na $\mathrm{CR}$ é estatisticamente significativa (C-teste, $\mathrm{p}=0,02$ ), com um perfil ascendente a partir dos $45-60$ minutos. A análise estatística da diferença de médias de secreção hormonal para os valores entre 0 e 120 minutos é significativa (Mann-Whitney, U-teste, $\mathrm{p}=0,0188$ ) (Quadro III), no entanto isto decorre dos valores mais elevados de secreção hormonal durante a CC.

As curvas da $\mathrm{CC}$ e da $\mathrm{CR}$ apresentam condições de chegada ao laboratório extremamente semelhantes, apesar do intervalo de 5 semanas entre as condições, com comportamentos semelhantes até os 45 minutos. $\mathrm{Na} \mathrm{CC}$, observa-se pico de secreção aos 75 minutos, com elevação final da secreção hormonal aos 120 minutos, e este perfil não guarda relação com a curva da CC do cortisol (Figura 7-B), a qual expressa o ritmo circadiano do hormônio. A elevação de secreção de ACTH entre os 45 minutos e 75 minutos é inexplicável, já que o sujeito não referiu qualquer conteúdo emocional ou lembrança durante essa fase. $\mathrm{O}$ final ascendente da secreção de ACTH observado entre os 105 e 120 minutos pode ser interpretado, possivelmente, como o resultado do retorno do sujeito à condição de vigília.

A elevação observada aos 30 minutos em ambas as condições se confunde. Na simples expressão temporal do fenômeno, observa-se perfil ascendente de secreção hormonal na CR a partir dos 60 minutos, coincidente com o Momento Mais Traumático o qual ocorre entre os 68 e os 75 minutos. 
A Figura 8-A exibe as variações relativas de secreção de ACTH. As oscilações observadas na CC são de tal ordem que não constituem um padrão, o que define o resultado estatístico. As variações relativas observadas na CR são homogeneamente ascendentes a partir dos 60 minutos, o que coincide com o Momento Mais Traumático.

Este fato, aliado à significância estatística da tendência da curva de secreção de ACTH na CR, apesar de não conclusivos, sugere estimulação da secreção do ACTH pelos conteúdos da vivência.

5.1.3.2. Cortisol (Figuras 7-B, 8-B e 9-B): a tendência decrescente do perfil de secreção de cortisol é estatisticamente significativa (C-teste, com p=0,00 para $\mathrm{CC}$ e $\mathrm{CR}$ ), exibindo o perfil da expressão do ritmo circadiano de secreção hormonal, responsável pelos resultados estatísticos. Concordantemente, a diferença de médias de secreção hormonal em ambas as condições ( $\mathrm{CC}$ e $\mathrm{CR}$ ) para os valores entre 0 e 120 minutos também não é significativa (Mann-Whitney, U-teste, $\mathrm{p}=0,7572$ ) (Quadro III), mesmo quando se exclui os valores observados entre 0 e 30 minutos (Mann-Whitney, U-teste, $p=0,6307$ ). Assim, as curvas de secreção hormonal da $\mathrm{CC}$ e da $\mathrm{CR}$ são indistinguíveis do início ao fim dos procedimentos.

A Figura 8-B exibe as variações relativas da secreção hormonal em ambas as condições e exibe perfis de variação negativa concordante com a expressão circadiana da secreção do cortisol.

Note-se a baixa auto-estima referida pela paciente durante a vivência, particularmente entre os 45 e os 68 minutos, que pode estar relacionada com a ausência de resposta do eixo HPA ao estresse. Com efeito, a baixa auto-estima parece afetar a resposta neuroendócrina ao estresse em voluntários submetidos a tarefas envolvendo sucesso e frustração experimentalmente induzidos, o que indica uma correlação negativa, estatisticamente significativa, entre os níveis da resposta do cortisol com essas tarefas e a auto-estima na 
condição de "fracasso“, mas não na condição de "sucesso", o que depende, naturalmente, da percepção subjetiva sobre o significado individual do que sejam "fracassos" e "sucessos" (PRUESSNER et al., 1999).

Assim, não houve resposta do córtex suprarenal aos conteúdos da vivência a despeito dos resultados obtidos com o ACTH, ressaltando-se o fato de que as mesmas considerações relativas ao TEPT anteriormente feitas para o sujeito 2 podem, em princípio, ser aqui aplicadas (YEHUDA et al., 1995; RESNIK et al., 1995).

5.1.3.3. Adrenalina (Figuras 7-C, 8-C e 9-C): a análise das tendências das curvas de secreção de adrenalina indica resultados estatisticamente significativos (C-teste, $p=0,01$ para a $\mathrm{CC}$ e $\mathrm{p}=0,00$ para a CR). A diferença das médias de secreção hormonal para os valores entre 0 e 120 minutos, não é significativa (Mann-Whitney, U-teste, p=0,7910) (Quadro III).

As curvas de secreção hormonal são quase indistinguíveis do início ao fim dos procedimentos, exibindo um perfil de onda positiva de secreção, com valores máximos da CC atingidos aos 60 minutos, no limite superior dos valores de referência para o ensaio, com os valores máximos da $\mathrm{CR}$ atingidos um pouco mais tarde, aos 90 minutos (o Momento Mais Traumático ocorreu entre os 45 e os 68 minutos), num valor que excede o limite superior dos valores de referência para o ensaio. Ambas as curvas apresentam valores ainda elevados aos 105 e 120 minutos.

A Figura 8-C, que mostra as variações relativas de secreção hormonal, exibe o fenômeno mais claramente, mostrando uma clara decalagem entre as curvas da CC e da CR a partir dos 60 minutos, isto é, houve variação relativa crescente de secreção hormonal mais intensa na $\mathrm{CR}$ do que na $\mathrm{CC}$ a partir dos 30 minutos, mantendo-se após os 60 minutos, o que é coincidente com a manifestação do MMT.

O perfil obtido com a curva da $\mathrm{CC}$ não tem explicação aparente, mesmo porque o sujeito não referiu emoção ou lembranças experimentadas durante a condição. Debita-se tal 
fato a uma condição de repouso não apropriadamente obtida: nessa linha de pensamento, uma hipótese seria também a de se admitir excitação autonômica devida ao desconhecimento que o sujeito tinha sobre os procedimentos adotados na $\mathrm{CC}$, isto é, punção venosa e coleta de material (fato já conhecido durante a CR); ou seja, houve estímulo de secreção de ACTH. Na CR, os níveis mais baixos de secreção de adrenalina entre os instantes 0 e 30 minutos podem expressar a ação dos procedimentos relativos ao Relaxamento e ao Aprofundamento.

No entanto, se tomarmos a curva da CR isoladamente, com tendência estatisticamente significativa ( $\mathrm{C}$-teste, $\mathrm{p}=0,00$ ), observa-se, a partir do início dos 30 minutos, um aumento sensível da secreção de adrenalina, que ultrapassa os limites superiores dos valores de referência para o ensaio, um máximo atingido aos 90 minutos, subseqüente à vivência que se manifestou entre os 45 e os 68 minutos, mantendo-se em valores significativamente mais elevados que os do instante 0 , inclusive no final dos procedimentos.

Com efeito, se excluirmos os valores entre instantes 0 e 30 minutos $(\mathrm{CC}$, repouso e $\mathrm{CR}$, Aprofundamento e Relaxamento) e testarmos quantitativamente os valores subseqüentes (vivência e procedimentos finais da técnica) encontraremos valores estatisticamente significativos (Mann-Whitney, U-teste, $\mathrm{p}=0,0450$ ), indicando, ao se admitir como estresse antecipatório o perfil da curva da CC, resposta autonômica aos conteúdos da vivência..

5.1.3.4. Prolactina (Figuras 7-D, 8-D e 9-D): as tendências das curvas de secreção de PRL mostram-se estatisticamente significativas (C-teste, $p=0,00$ para a CC e $p=0,02$ para a CR). A diferença de secreção hormonal para os valores entre 0 e 120 minutos, é significativa (Mann-Whitney, U-teste, $\mathrm{p}<0,0001)$ (Quadro III).

Observa-se perfil descendente da secreção de prolactina na CC, expressando a somatória do repouso atingido com a expressão circadiana de secreção hormonal. O perfil da curva da $\mathrm{CR}$, flutuando num patamar mais elevado do que o da CC, depois de apresentar aumento durante o repouso de 30 minutos que precedeu o início dos procedimentos, é 
sensivelmente mais elevado do que o da curva da $\mathrm{CC}$ e descendente durante as fases de Relaxamento e de Aprofundamento. O patamar mais elevado da secreção de prolactina na CR pode ser explicado por um estado funcional diferente do que o observado na $\mathrm{CC}$, pois houve uma diferença de cinco semanas entre os procedimentos. A Figura 8-D, expressando as variações hormonais relativas ao instante 0 , exibe curvas de variação hormonal praticamente indistinguíveis.

Como a prolactina é um hormônio muito sensível ao estresse, é possível que esse aumento de secreção durante o repouso represente estresse antecipatório ao fenômeno da RecMem, estresse que se reduziu, depois, em resposta às fases de Relaxamento e de Aprofundamento. A partir dos 45 minutos, em plena vivência, que se dá entre os 45 e os 68 minutos, a secreção hormonal apresenta uma onda positiva. Na Figura 8-D observa-se que as curvas se invertem, mostrando maior variação de secreção hormonal na $\mathrm{CR}$ do que na $\mathrm{CC}$, secreção esta que atinge um valor máximo, mais ou menos estável, entre 60 e 75 minutos, para depois se estabilizar a partir dos 105 minutos.

A vivência se caracteriza por sentimento de humilhação, ressaltando que o aspecto qualitativo das emoções e de sentimentos experimentados é importante para a determinação da resposta hormonal (SOBRINHO, 2003).

Tal fato indica resposta da prolactina aos conteúdos da vivência.

5.1.3.5. TSH (Figuras 7-E, 8-E e 9-E): a tendência das curvas de secreção de TSH não é estatisticamente significativa ( $C$-teste, $p=0,10$ para a $C C$ e $p=0,36$ para a $C R$ ) assim como a diferença das médias de secreção hormonal para os valores entre 0 e 120 minutos, não é significativa (Mann-Whitney, U-teste, $p=0,7962$ ) (Quadro III), o que se repete entre 45 e 120 minutos (Mann-Whitney, U-teste, $\mathrm{p}=0,1797$ ).

A Figura 8-D mostra que as variações relativas de secreção do TSH em ambas as condições (CC e CR) são indistinguíveis ao longo do tempo. 
Não há evidências sugestivas de resposta de secreção do TSH aos conteúdos da vivência.

5.1.3.6. GH (Figuras 7-F, 8-F e 9-F): a tendência das curvas de secreção de GH é estatisticamente significativa (C-teste, $\mathrm{p}=0,00$ na $\mathrm{CC}$ e $\mathrm{p}=0,00$ na $\mathrm{CR}$ ). A diferença de secreção hormonal para os valores entre 0 e 120 minutos não é significativa (Mann-Whitney, U-teste, $p=0,3096$ ) (Quadro III), a despeito do enorme aumento de secreção de GH observada na CR a partir dos 60 minutos (em plena vivência), que ultrapassa em muito os limites superiores dos valores de referência para o ensaio. Utilizando-se dos valores de secreção hormonal entre 45 e 120 minutos (CC, repouso e CR, vivência e fases subseqüentes) obtemos resultados igualmente não significativos (Mann-Whitney, U-teste, $p=0,2403$ ).

$\mathrm{Na}$ CC existe um segmento ascendente final entre 75 e 120 minutos de cerca de três vezes e meia em relação ao valor de 75 minutos e, na $\mathrm{CR}$, um aumento de aproximadamente 84 vezes na secreção hormonal.

Na primeira parte da Figura 5-F, até os 60 minutos, as curvas de secreção hormonal praticamente se superpõem. Dos 45 minutos aos 68 minutos, dá-se a vivência, com importante conteúdo emocional. Há, assim, clara relação temporal entre ela e o estímulo de secreção do $\mathrm{GH}$, que se dá de maneira intensa a partir dos 60 minutos.

Duas hipóteses devem ser consideradas: a associação entre a elevação da secreção de adrenalina a partir dos 30-40 minutos e o grande incremento de secreção do GH a partir dos 60 minutos (GIUSTINA; VELDHUIS, 1998), ou que essa elevação represente pulso de liberação espontânea do GH, valendo aqui o que se discutiu anteriormente sobre as características dos picos de secreção de GH (WINER et al., 1990). Se observarmos, no entanto, o mesmo perfil de secreção nos sujeitos 2 e 5, com dramática elevação do GH, sempre na $\mathrm{CR}$, em associação com intensos conteúdos emocionais, e com secreção constante durante a CC, essa última hipótese fica mais distante. 
O dados indicam que a elevação da secreção do GH observada durante a CR se deu em resposta aos conteúdos da vivência.

\subsubsection{Resumo:}

Os dados observados no sujeito analisado apenas sugerem estímulo de secreção do ACTH, indicam resposta da adrenalina, da prolactina e do $\mathrm{GH}$ em associação com a vivência.

5.1.4. SUJEITO 4 - RSJ, 25 anos, sexo masculino.

As respostas observadas no sujeito em questão estão representadas pela Tabela IV e pelas Figuras 10,11 e 12, de A a F.

5.1.4.1. ACTH (Figuras 10-A, 11-A e 12-A): as tendências das curvas de secreção hormonal são estatisticamente significativas (C-teste, $p=0,00$ para $C C$ e $C R$ ). A diferença das médias de secreção hormonal entre 0 e 120 minutos, não é significativa (Mann-Whitney, Uteste, $\mathrm{p}=0,6581$ ) (Quadro IV), que se repete para os valores entre 45 e 120 minutos (MannWhitney, U-teste, $\mathrm{p}=0,8095)$.

O repouso prévio de 30 minutos é suficiente para que a secreção hormonal se inicie em valores indistinguíveis. As curvas de secreção hormonal correm juntas do início ao fim dos procedimentos, de aspecto descendente, sugerindo expressão circadiana do hormônio, exceto pelo valor de chegada ao laboratório na $\mathrm{CC}$, sensivelmente mais elevada do que no instante correspondente na CR (maior estresse de chegada ao laboratório).

A Figura 11-A mostra variações relativas de secreção do ACTH indistinguíveis ao longo dos procedimentos.

Dadas as características da vivência, pode se especular que tenha havido inibição do eixo HPA de maneira semelhante à observada no TEPT (YEHUDA et al., 1995; RESNIK et al., 1995).

Não existem evidências de resposta do ACTH aos conteúdos da vivência. 
5.1.4.2. Cortisol (Figuras 10-B, 11-B e 12-B): o perfil de secreção hormonal exibido na $\mathrm{CC}$ não é estatisticamente significativo ( $\mathrm{C}$-teste, $\mathrm{p}=0,32)$ e o da $\mathrm{CR}$ é estatisticamente significativo ( $\mathrm{C}$-teste, $\mathrm{p}=0,00$ ). A diferença das médias de secreção hormonal para os valores entre 0 e 120 minutos, é significativa ( $\mathrm{M}<\mathrm{ann}$-Whitney, U-teste, $\mathrm{p}<0,0001)$ (Quadro IV), mas entre 45 e 120 minutos não é estatisticamente significativa (Mann-Whitney, U-teste, $\mathrm{p}=0,6991)$.

O perfil da curva da CC representa o estado de relaxamento em que o paciente se encontrava durante todo o procedimento, em relação de causalidade com a curva da CC do ACTH (Figura 11-A), sugerindo expressão circadiana de secreção hormonal.

A curva relativa à $\mathrm{CR}$ se apresenta num patamar significativamente mais elevado do que a curva da $\mathrm{CC}$, o que pode representar estados fisiológicos diferentes; no entanto, todos os valores se inserem dentro dos limites de referência para o ensaio. Isto pode expressar o resultado da diferença de sete dias entre um e outro procedimento. O perfil da curva da $\mathrm{CR}$ exibe aspecto descendente também sugestivo do ritmo circadiano de secreção hormonal a partir dos 45 minutos, exceto pelo fato de não exibir redução significativa durante as fases de Relaxamento e de Aprofundamento, o que também é observado na curva da CR para o ACTH (Figura 7-A), e de não exibir modificações significativas durante e após a vivência, o que é concordante com a curva da CR observada para o ACTH.

Assim, a despeito do fato de as curvas da CC e da CR diferirem de maneira estatisticamente significativa, a análise temporal do fenômeno indica ausência de resposta do cortisol à vivência.

5.1.4.3. Adrenalina (Figuras $10-\mathrm{C}, 11-\mathrm{C}$ e $12 \mathrm{C}$ ): as tendências de secreção hormonal são estatisticamente significativas (C-teste, $\mathrm{p}=0,00$ para $\mathrm{CC}$ e $\mathrm{CR}$ ) e a diferença das médias de secreção hormonal para os valores entre 0 e 120 minutos, não é significativa (U-teste, 
$\mathrm{p}=0,7910$ ) (Quadro IV). Para os valores entre 45 e 120 minutos, o valor de $\boldsymbol{p}$ se situa um pouco acima do limite de significância estatística (Mann-Whitney, U-teste, $p=0,0780$ ).

A curva da $\mathrm{CC}$ exibe um perfil ascendente, o que aponta para que tenha havido ativação autonômica ao longo da CC. Essa ativação é inexplicável, já que o repouso foi satisfatório e o sujeito não referiu qualquer lembrança ou emoção durante a referida condição. Fica a possibilidade de que a ativação seja decorrente do estresse gerado pelos procedimentos de coleta de material a cada 15 minutos.

Os valores de adrenalina na curva da CR mostram aumento de secreção hormonal entre os 60 e os 105 minutos, com rápida queda para valores indistinguíveis dos observados aos 120 minutos na curva da CC. O fenômeno pode ser melhor visto em termos de variação relativa de secreção hormonal na Figura 11-C que exibe perfil ascendente de variação a partir dos 60 minutos.

A Rec-Mem produziu vivência caracterizada por intenso conteúdo emocional, quando a raiva e o medo foram emoções dominantes entre os 56 aos 85 minutos. É possível, apesar dos dados não serem conclusivos, que essa elevação tenha se devido a resposta da medula suprarenal à vivência

5.1.4.4. Prolactina (Figuras 10-D, 11-D e 12-D): as tendências observadas nas curvas de secreção hormonal são estatisticamente significativas (C-teste, $p=0,03$ para a CC e $p=0,02$ para a CR). A diferença das médias de secreção hormonal entre 0 e 120 minutos é significativa (Mann-Whitney, U-teste, p <0,0001) (Quadro IV). Entre 45 e 120 minutos, continua sendo estatisticamente significativa (Mann-Whitney, U-teste, $\mathrm{p}=0,0450$ ).

Ambas as curvas são descendentes até os 45 minutos e situadas em patamares diferentes. A curva da $\mathrm{CC}$ então se torna ascendente até os 120 minutos (incremento de $14,43 \%$ em relação ao instante 0 ). É possível que este incremento se deva ao progressivo retorno à condição de vigília. Dado que houve um espaço de sete dias entre a $\mathrm{CC}$ e a CR, a 
diferença de seus patamares se torna compreensível, mesmo porque todos os valores se situam dentro dos limites dos valores de referência para o ensaio.

A curva da CR, após pequena queda durante as fases de Relaxamento e de Aprofundamento, mostra uma onda positiva de secreção a partir dos 45 minutos, atinge um máximo aos 75 minutos (23,41\% maior que os valores do instante 0$)$, e depois se reduz até o final dos procedimentos. A Figura 11-D exibe melhor este fenômeno.

O segmento da curva da $\mathrm{CR}$ que representa aumento da secreção de prolactina é coincidente com a vivência, na qual raiva (SOBRINHO, 2003) e medo foram emoções dominantes. Tal fato sugere resposta da prolactina ao estresse gerado pela vivência.

5.1.4.5. TSH (Figuras 10-E, 11-E e 12-E): a flutuação observada na curva de secreção de TSH na CC não é estatisticamente significativa (C-teste, $p=0,36$ ) mas, na $C R$, é estatisticamente significativa (C-teste, $\mathrm{p}=0,04)$. A diferença das médias de secreção hormonal para os valores entre 0 e 120 minutos, também é significativa: Mann-Whitney, U-teste, p $<0,0001$ (Quadro IV); porém, entre 45 e 120 minutos, esta diferença se torna estatisticamente não significativa (Mann-Whitney, U-teste, $p=0,4230$ ).

O perfil de ambas as curvas é semelhante ao observado na secreção de prolactina. A curva da CC é descendente ao longo do tempo, o que sugere expressão circadiana de secreção hormonal. A pequena elevação observada entre os 90 minutos e os 105 minutos pode representar a coincidência da coleta com um pico espontâneo de secreção hormonal. A curva da CR se situa num patamar mais elevado (CC e CR realizadas com sete dias de intervalo) e apresenta um segmento ascendente de secreção do TSH de cerca de $10 \%$ a partir dos 60 minutos (vivências com intenso conteúdo emocional entre 56 e 85 minutos), com queda subseqüente durante das fases finais dos procedimentos.

Tal perfil sugere resposta do TSH aos conteúdos da vivência; no entanto não são conclusivos para ela. 
5.1.4.6. GH (Figuras $10-\mathrm{F}, 11-\mathrm{F}$ e $12-\mathrm{F})$ : a tendência da curva de secreção de GH na CC não é estatisticamente significativa (C-teste, $\mathrm{p}=0,69$ ); na $\mathrm{CR}$ é estatisticamente significativa (C-teste, $\mathrm{p}=0,00$ ), e a diferença das médias de secreção hormonal para os valores entre 0 e 120 minutos, é significativa (Mann-Whitney, U-teste, $\mathrm{p}<0,0001$ ) (Quadro IV); entre 45 e 120 minutos, continua significativa (Mann-Whitney, U-teste, $\mathrm{p}=0,0022$ ).

É possível que o patamar de secreção de GH mais elevado na CR seja devido tanto ao fato de $\mathrm{CC}$ e $\mathrm{CR}$ terem sido realizadas com intervalo de sete dias quanto ao estresse antecipatório aos procedimentos destinados à Rec-Mem. Se compararmos, no entanto, as curvas de secreção de adrenalina com as de $\mathrm{GH}$, nos pacientes 2,3 e 5 vemos que o incremento de secreção do GH, possivelmente por estimulação $\alpha-2$ adrenérgica (GIUSTINA; VELDHUIS, 1994) se dá sempre com um atraso de 15 a 30 minutos em relação ao aumento da secreção da adrenalina. Como o aumento significativo de adrenalina nesse paciente se deu aos 105 minutos, e os procedimentos se encerraram aos 120 minutos, não se pode saber se este aumento ocorreu.

A Figura 11-F exibe as variações relativas observadas em ambas as condições.

Não houve resposta do GH aos conteúdos da vivência.

5.1.4.7. Resumo: os dados observados no sujeito observado sugerem estímulo de secreção da prolactina e TSH em associação com a vivência, e discutível estimulação da medula suprarenal.

5.1.5. SUJEITO 5 - HLVF, 59 anos, sexo masculino.

As respostas observadas no sujeito observado estão representadas na Tabela V, pelas Figuras 13, 14 e 15, de A a F.

5.1.5.1. ACTH (Figuras 13-A, 14-A e 15-A): na CC, as flutuações de secreção do ACTH não são estatisticamente significativas (C-teste, $p=0,09)$ enquanto que a tendência ascendente observada na $\mathrm{CR}$ é estatisticamente significativa ( $\mathrm{C}$-teste, $\mathrm{p}=0,00)$. A diferença 
das médias de secreção hormonal entre 0 e 120 minutos é significativa (Mann-Whitney, Uteste, $\mathrm{p}<0,0001$ (Quadro V), assim como para os valores entre 45 e 120 minutos (MannWhitney, U-teste, $\mathrm{p}=0,0022$ ).

As curvas das condições CC e CR são distintas do início ao fim dos procedimentos. Enquanto que a curva da CC exibe um perfil estável, a curva da CR é descendente até o final do Relaxamento e do Aprofundamento, aos 30 minutos, quando o paciente dormiu. A partir daí, a curva exibe um perfil ascendente de secreção hormonal, com um pequeno pico durante a vivência (dos 45 aos 70 minutos), seguido por aumento da secreção de ACTH até o final dos procedimentos, aos 120 minutos, com valores sensivelmente mais elevados do que os da curva da CC.

Tal fenômeno se revela por meio da Figura 14-A, onde a variação positiva de secreção de ACTH se revela com toda a clareza.

A vivência desse sujeito é de conteúdo extremamente violento e com intenso conteúdo emocional a partir dos 41 minutos. Assim, os resultados observados são indicativos de estimulação da produção hipofisária de ACTH como resposta aos conteúdos da vivência.

5.1.5.2. Cortisol (Figuras 13-B, 14-B e 15-B): o aspecto descendente das curvas de secreção hormonal observado nas CC e CR deste sujeito é estatisticamente significativo (Cteste, $\mathrm{p}=0,01$ para a $\mathrm{CC}$ e $\mathrm{p}=0,00$ para a $\mathrm{CR}$ ). A diferença das médias de secreção hormonal para os valores entre 0 e 120 minutos é significativa (Mann-Whitney, U-teste, $p=0,0012$ ) (Quadro V); entre 45 e 120 minutos, o valor de $\boldsymbol{p}$ se situa ligeiramente acima do limite de significância estatística (Mann-Whitney, U-teste, p=0,0065).

As curvas de secreção hormonal na $\mathrm{CC}$ e na $\mathrm{CR}$ iniciam-se em valores muito próximos, a partir do instante 0 . Observa-se fenômeno comparável de decalagem discutido para o ACTH nas curvas da $\mathrm{CC}$ e da $\mathrm{CR}$ para o cortisol, numa sugestiva relação de causalidade. 
Embora ambas as curvas sejam descendentes, sugerindo expressão circadiana de secreção hormonal e enquanto que a curva de secreção do cortisol na CC é descendente a partir do início dos procedimentos numa razão de queda mais intensa, sugerindo expressão do ritmo circadiano, na curva da $\mathrm{CR}$ observam-se valores mais elevados na $\mathrm{CR}$ em relação à $\mathrm{CC}$ a partir dos 15 minutos, valor este que se amplia até os 120 minutos, numa razão de queda mais suave, sugerindo atenuação da expressão circadiana. A Figura 14-B exibe este fenômeno mais claramente, sugerindo que as variações relativas de secreção hormonal na CR não se deram na mesma intensidade que na CC.

A ausência de um aumento significativo de secreção de cortisol em resposta ao aumento de secreção de ACTH pode significar possível resposta do eixo HPA devida a uma situação do tipo TEPT (YEHUDA et al., 1995; RESNIK et al., 1995), ou relativa à baixa autoestima (PRUESSNER et al., 1999) apresentada pelo sujeito.

Tomando em conjunto as secreções de ACTH e cortisol na CR, assim como a decalagem entre as curvas de ambos os hormônios em ambas as condições (CC e CR), há evidências indicativas da estimulação eixo HPA na $\mathrm{CR}$ em resposta à vivência.

5.1.5.3. Adrenalina (Figuras $13-\mathrm{C}, 14-\mathrm{C}$ e $15-\mathrm{C}$ ): a análise das tendências indica que enquanto na CC ela é estatisticamente significativa (C-teste, $p=0,04$, na $C R$, a despeito da clara diferença entre as curvas, é atribuível ao acaso (C-teste, $\mathrm{p}=0,11)$. Mas a diferença das médias de secreção entre 0 e 120 minutos é significativa (Mann-Whitney, U-teste, p=0,0340 (Quadro V), que se acentua entre 45 e 120 minutos (Mann-Whitney, U-teste, $\mathrm{p}=0,0043$ ), principalmente se considerando que ambas as curvas se iniciam em valores praticamente indistinguíveis.

A partir dos 15 minutos, a curva da CC é descendente até os 75 minutos, quando sofre abrupta elevação, atingindo valores, aos 105 e 120 minutos, indistinguíveis dos valores observados na curva da $\mathrm{CR}$, se estabilizando em valores comparáveis aos observados no 
instante de 0 minuto. É possível que esta elevação do segmento final da curva da CC seja devido ao progressivo retorno do sujeito à condição de vigília.

A curva da CR é ascendente, já a partir dos 15 minutos, na fase de Relaxamento, apresentando dois períodos de aumento de secreção hormonal: um, entre os 15 e os 45 minutos, justamente durante a fase em que o sujeito dormiu por breves instantes. Durante estes breves momentos o sujeito não referiu ter experimentado qualquer manifestação emocional ou lembranças que pudessem se relacionar com este perfil ascendente de secreção hormonal, mas pode-se especular, tal como na secreção do ACTH do sujeito 1, que represente a emergência do material psíquico que iria atingir o plano da consciência algum tempo depois. O outro período de elevação de secreção hormonal se dá entre os 60 minutos e os 75 minutos. Os valores atingidos entre os 15 e os 90 minutos são bem mais elevados do que os observados na $\mathrm{CC}$, se aproximando bastante do limite superior dos valores de referência para o ensaio. Este perfil ascendente e irregular da secreção de adrenalina é coincidente com os aspectos mais traumáticos e emocionais experimentados pelo sujeito, sugerindo forte relação com a Rec-Mem, a partir dos 41 minutos. Vê-se que a raiva foi emoção constante ao longo destes dois picos de secreção hormonal.

A partir 75 minutos, as curvas tendem a se igualar e se tornam indistinguíveis, devido à queda dos valores da curva da CR e elevação dos valores ascendentes da curva da CC. Esta queda dos valores de secreção hormonal da curva da CR sugere tratar-se da somação da extinção da resposta ao estresse com o resultado dos processos destinados a reconduzir o sujeito ao estado normal de vigília.

A Figura 14-C exibe claramente o fenômeno por meio das variações relativas de secreção hormonal.

Estes fatos indicam a estimulação autonômica da medula supra-renal como resposta aos conteúdos da vivência. 
5.1.5.4. Prolactina (Figuras 13-D, 14-D e 15-D): as flutuações hormonais observadas na curva de secreção de prolactina na CC não são estatisticamente significativas (C-teste, $\mathrm{p}=0,44$ ) enquanto que a tendência fortemente ascendente da secreção hormonal observada a partir dos 45 minutos é estatisticamente significativa ( $\mathrm{C}$-teste, $\mathrm{p}=0,00$ ). Apesar disso, diferença entre as médias de secreção hormonal entre 0 e 120 minutos, não é significativa: Mann-Whitney, U-teste, $\mathrm{p}=0,7304$ (Quadro V).

Observando o fenômeno em função do tempo, vemos que as curvas de secreção hormonal seguem paralelas até os 75 minutos, com a curva da CR correndo em valores inferiores aos da curva da $\mathrm{CC}$, apresentando uma pequena queda até os 45 minutos, representando o resultado dos procedimentos de Relaxamento e Aprofundamento. A partir daí, a curva da CR exibe aumento de secreção hormonal que se torna muito mais elevado do que os observados, ponto a ponto, na curva da CC. É, assim, a partir dos 45 minutos, em plena vivência (que ocorreu a partir dos 41 minutos), que se observa elevação intensa da secreção de prolactina (aumento de 114,85 \%) atingindo um valor máximo aos 105 minutos.

Com efeito, se excluirmos os valores entre 0 e 30 minutos $(\mathrm{CC}$, repouso e $\mathrm{CR}$, Relaxamento e Aprofundamento), encontraremos resultados levemente acima do limite de significância estatística (Mann-Whitney, U-teste, $\mathrm{p}=0,0649$ ).

A Figura 14-D mostra claramente o fenômeno.

Isto indica resposta aos conteúdos da vivência, adicionando-se o fato de que a raiva foi emoção predominante (SOBRINHO, 2003).

5.1.5.5. TSH (Figuras 13-E, 14-E e 15-E): ocorre aqui um fenômeno comparável ao descrito para a prolactina: as flutuações observadas na curva de secreção hormonal da CC não são estatisticamente significativas $(\mathrm{C}$-teste, $\mathrm{p}=0,15)$ enquanto que na $\mathrm{CR}$, a tendência da curva é ascendente e estatisticamente significativa ( $\mathrm{C}$-teste, $\mathrm{p}=0,01$ ). Apesar disso, a diferença das médias de secreção hormonal entre 0 e 120 minutos, não é significativa (Mann-Whitney, U- 
teste, $\mathrm{p}=0,0625$ ) (Quadro V), porém, com valor de $\boldsymbol{p}$ ligeiramente acima do limite de significância estatística. Se, no entanto, excluirmos os instantes entre 0 e 30 minutos (repouso na CC e Relaxamento e Aprofundamento na CR), encontraremos resultados estatisticamente significativos (Mann-Whitney, U-teste, $\mathrm{p}=0,0043$ ), demonstrando maior secreção de TSH na CR do que na CC nestas fases.

A curva de secreção hormonal da CC apresenta, entre os tempos de 30 e 75 minutos, valores mais elevados do que os observados na curva da CR. Duas hipóteses são admissíveis: uma, pelo fato de CC e CR terem sido realizadas com sete dias de intervalo, portanto em estados fisiológicos diferentes (os valores das dosagens hormonais se situam dentro dos limites dos valores de referência para o ensaio); outra, que isto represente a eficiência dos processos de Relaxamento e Aprofundamento utilizados nas fases iniciais da técnica durante a CR, fenômeno comparável ao observado para a prolactina. Provavelmente, a isto se deve o valor de $p$ se situar um pouco acima dos limites de significância estatística testando todos os pontos, mas não para os relativos à vivência e procedimentos subseqüentes (Mann-Whitney, U-teste, $p=0,0043$ ), reforçando os termos da discussão anterior. Ressalte-se que o TRH é potente estimulador da secreção de ambos os hormônios, sugerindo que o mesmo fato tenha acontecido com a prolactina.

Com efeito, avaliando o fenômeno ao longo do tempo, vemos que a curva da CR apresenta forte elevação a partir dos 60 minutos atingindo um valor máximo aos 90 minutos, ao longo de um período que se superpõe, entre os 41 e os 75 minutos, à vivência experimentada pelo sujeito (incremento de 95,65\% em relação ao instante de 45 minutos, $114,28 \%$ em relação ao instante 0 e 136,84 \% em relação do instante de 60 minutos). Então, no final dos procedimentos, se situa num valor de ainda $97,61 \%$ acima do valor observado no tempo de 0 minuto. 
A Figura 14-E, mostrando as variações relativas e positivas de secreção de prolactina durante a CR exibe claramente o fenômeno, que, aliado ao fato de que a tendência da curva da CR é significativa (C-teste, $p=0,0100$ ), indica resposta do TSH aos conteúdos da vivência.

5.1.5.6. GH (Figuras 13-F, 14-F e 15-F): as tendências observadas nas curvas de secreção de GH são estatisticamente significativas (C-teste, $p=0,01$ na $C C$ e $p=0,00$ na $C R$ ). Apesar disso, a diferença das médias de secreção hormonal entre 0 e 120 minutos, não é significativa (Mann-Whitney, U-teste, $\mathrm{p}=0,0770$ ) (Quadro V). Se tomarmos apenas os valores de secreção hormonal entre 45 e 120 minutos $(\mathrm{CC}$, repouso e $\mathrm{CR}$, vivência e fases subseqüentes) obteremos resultados estatisticamente significativos (Mann-Whitney, U-teste, $\mathrm{p}=0,0043)$.

$\mathrm{Na} \mathrm{CC}$ existe uma pequena onda positiva de secreção hormonal entre os instantes de 45 e 120 minutos, com um incremento de cerca de $87 \%$ na secreção hormonal entre 45 e 75 minutos. Esta onda, inexplicável, é que confere significância estatística à tendência desta curva.

Por outro lado, observa-se aqui fenômeno comparável ao descrito para os sujeitos 2 e 3: a partir dos 45 minutos, em plena vivência, na $\mathrm{CR}$, ocorre intenso incremento na secreção do GH, ultrapassando os limites superiores dos valores de referência do ensaio aos 120 minutos, em caráter ainda ascendente, representando um incremento de $4350 \%$ em relação ao instante 0. A Figura 14-F exibe a enorme variação positiva de secreção do GH.

Levadas em conta as mesmas considerações feitas para os sujeitos 2 e 3 (WINER et al., 1990) com respeito aos picos espontâneos de liberação de GH, sua associação com intensos conteúdos emocionais da vivência, e ocorrendo sempre durante a $C R$, e a relação da estimulação dos receptores alfa- 2 e beta- 2 adrenérgicos, com resultante secreção do $\mathrm{GH}$ (CATALDI et al., 1994; GIUSTINA; VELDHUIS, 1998), com acoplamento temporal com atraso de 15 minutos em relação ao primeiro pico de adrenalina entre os 30 e os 45 minutos, e 
provavelmente reforçado pelo pico aos 75 minutos, o perfil secretório observado indica resposta de secreção do GH à vivência, reforçado pelo valor de $\boldsymbol{p}$ situado não muito acima do limite de significância estatística para os instantes entre 0 e 120 minutos, mas significativo quando se utilizam os valores entre 45 e 120 minutos, em ambas as condições (MannWhitney, U-teste, $\mathrm{p}=0,0411$ ).

Os dados indicam resposta do GH aos conteúdos da vivência.

5.1.5.7. Resumo: os dados observados neste sujeito indicam resposta do eixo HPA, da medula suprarenal, da prolactina, do TSH e do GH à vivência.

5.1.6. SUJEITO 6 - ASTR, 52 anos, sexo masculino.

As respostas observadas no sujeito em análise estão representadas pela Tabela VI e pelas Figuras 16, 17 e 18, de A a F.

5.1.6.1. ACTH (Figuras 16-A, 17-A e 18-A): as flutuações de secreção do ACTH não são estatisticamente significativas ( $\mathrm{C}$-teste, $\mathrm{p}=0,21$ para a $\mathrm{CC}$ e $\mathrm{p}=0,24$ para a $\mathrm{CR}$ ). A diferença das médias de secreção hormonal entre 0 e 120 minutos, também não é significativa (Mann-Whitney, U-teste, $\mathrm{p}>0$,9999) (Quadro VI), o que se repete para os valores entre 45 e 120 minutos (Mann-Whitney, U-teste, $\mathrm{p}=0,1082$ ).

Os perfis de secreção de $\mathrm{ACTH}$ nas curvas da $\mathrm{CC}$ e da $\mathrm{CR}$ são praticamente indistinguíveis. A curva de secreção hormonal da CC apresenta-se com oscilações a partir dos 30 minutos dos procedimentos, terminando em níveis mais elevados do que os observados no repouso de trinta minutos. Dado que o sujeito permaneceu em repouso, é possível, também, que esse perfil seja devido ao fato que o sujeito viajou a noite toda de ônibus, com sono entrecortado tendo chegado a São Paulo, proveniente do interior, e se dirigido diretamente para o laboratório, com a pequena refeição recomendada por volta das $6: 30 \mathrm{hs,} \mathrm{ou,} \mathrm{ainda,} \mathrm{ao}$ seu leve estado gripal. 
A curva da secreção do ACTH na CR se expressa de modo diferente: há uma redução pequena, porém progressiva, da secreção do $\mathrm{ACTH}$, a partir do instante de chegada ao laboratório e ao longo dos procedimentos de Relaxamento e de Aprofundamento, até os 30 minutos. Aos 15 minutos, o sujeito manifestava dificuldade em relaxar, o que pode ter impedido que a queda fosse mais acentuada. Entre 30 e 45 minutos, ocorre elevação da secreção do ACTH. A elevação coincide com o instante em que o paciente experimenta o início de sua vivência com intenso sofrimento e mal-estar, que evolui para a sensação de peso no abdome a qual se mantém até os 68 minutos, quando o sujeito identifica a origem dessa sensação: violenta agressão física. Entre os 71 os 90 minutos, as emoções são muito intensas e, aos 90 minutos, experimenta a eminência de sua própria morte. O segmento da curva de secreção do ACTH se mantém em níveis ligeiramente mais elevados do que os observados aos 30 minutos, até os 105 minutos, quando termina a vivência.

No entanto, as variações relativas de secreção hormonal observada na CC são mais intensas do que na CR (Figura 17-A).

Se os compararmos com o observado nas curvas de secreção do cortisol (Figura 17-B), vemos que o perfil de secreção do $\mathrm{ACTH}$ na $\mathrm{CC}$ pode ter sido perturbado pela noite insone. Se compararmos as curvas de secreção de ACTH e cortisol na CR, vemos que existe uma relação temporal esperada entre a elevação de secreção do ACTH, entre 30 e 45 minutos, e a elevação de secreção do cortisol, a partir dos 60 minutos.

Apesar disso, as evidências não são conclusivas para estimulação do ACTH relativa aos conteúdos da vivência.

5.1.6.2. Cortisol (Figuras 16-B, 17-B e 18-B): as tendências observadas nas curvas de secreção de cortisol são estatisticamente significativas (C-teste, $p=0,01$ para a $\mathrm{CC}$ e $\mathrm{p}=0,04$ para a CR). A diferença das médias de secreção entre 0 e 120 minutos, é significativa (MannWhitney, U-teste, $\mathrm{p}<0,0001$ ) (Quadro VI), que se repete entre 45 e 120 minutos, com um 
valor de $\boldsymbol{p}$ ligeiramente acima do limite de significância estatística (Mann-Whitney, U-teste, $\mathrm{p}=0,0651$ ). Este nível de significância estatística também se deve aos patamares diferentes de secreção hormonal entre as curvas, devido à diferença de sete dias entre os procedimentos e a estados fisiológicos de base possivelmente diferentes.

O perfil da curva de secreção do cortisol na CC segue o mesmo padrão de irregularidade observado para o ACTH na CC (figura 16-A), o que sugere estresse como elemento perturbador da expressão da atividade do eixo HPA, pelas razões já apresentadas.

É possível se estabelecer uma relação de causalidade entre as curvas do ACTH e do cortisol na CR.

Observa-se queda da secreção do cortisol entre 0 e 45 minutos de 10,28\%, que se explica pela possível somatória dos efeitos do Relaxamento e do Aprofundamento com a expressão circadiana da secreção hormonal (para o ACTH, entre 0 e 30 minutos). A variação relativa positiva de secreção do cortisol se dá a partir dos 45 minutos (Figura 11-B) (início da vivência) com o atraso esperado em relação à secreção do ACTH (ativação do eixo HPA) (MILUK-KOLASA et al., 1994). A partir daí, até o final dos procedimentos da CR, e seguindo uma relação de causalidade com curva de secreção do $\mathrm{ACTH}$, a secreção do cortisol é ascendente até os 120 minutos, representando uma elevação de $14,58 \%$ em relação aos 45 minutos, sendo indistinguível do valor observado no início dos procedimentos.

Os dados observados indicam resposta fisiológica, compatível com estimulação do córtex supra-renal aos conteúdos da vivência.

5.1.6.3. Adrenalina (Figuras 16-C, $17-\mathrm{C}$ e 18-C): as flutuações de secreção de adrenalina na $C C$ não são estatisticamente significativas $(C$-teste, $p=0,09)$ e na curva na $C R$ são estatisticamente significativas ( $\mathrm{C}$-teste, $\mathrm{p}=0,00)$. A diferença das médias de secreção hormonal entre 0 e 120 minutos, não é significativa (Mann-WhitneyU-teste, $\quad p=0,1993$ ) 
(Quadro VI); para os valores entre 45 e 120 minutos, torna-se significativa (Mann-Whitney, U-teste, $\mathrm{p}=0,0043)$.

Observa-se que a curva de secreção de adrenalina na $\mathrm{CC}$ apresenta perfil irregular e descendente até o final dos procedimentos.

A condição de chegada ao laboratório na $\mathrm{CR}$ é equivalente à da $\mathrm{CC}$, mas após o repouso de 30 minutos se eleva, possivelmente devido ao estresse antecipatório aos procedimentos. A partir do instante 0 a secreção de adrenalina se reduz, coincidentemente com o Relaxamento e Aprofundamento, prolongando-se durante a vivência até os 75 minutos quando atinge os valores observados na condição de chegada ao laboratório. Então, aos 75 minutos sofre deflexão positiva em seu perfil de $10,71 \%$ entre os 75 e os 90 minutos, em plena vivência de ameaça de morte do sujeito, aos 90 minutos (variação relativa de secreção positiva, na Figura 17-C).

Isto sugere inversão temporal de resposta do eixo HPA e da medula supra-renal ao estresse: em primeiro, o eixo HPA e depois a medula supra-renal, quando o esperado seria o oposto (WOLF, 2003), valendo aqui as mesmas considerações anteriormente feitas relativas ao disparo temporalmente diferenciado dos neurônios do sistema CRH.

Os dados observados sugerem possível estimulação da medula suprarenal na vivência, devida à relação temporal da curva de secreção hormonal e a vivência experimentada pelo sujeito, particularmente entre os 75 e os 90 minutos.

5.1.6.4. Prolactina (Figuras 16-D, 17-D e 18-D): as flutuações de secreção hormonal durante a CC não são estatisticamente significativas (C-teste, p=0,24) e, na $C R$, são estatisticamente significativas (C-teste, $\mathrm{p}=0,01$ ). A diferença entre as médias de secreção hormonal entre 0 e 120 minutos, é significativa (Mann-Whitney, U-teste, p<0,0001) (Quadro VI); que se repete entre 45 e 120 minutos (Mann-Whitney, U-teste, $p=0,0022$ ).

A curva de secreção de prolactina na CC é homogênea e descendente. 
A curva de secreção da CR situa-se em valores significativamente mais elevados já no início dos procedimentos, apesar de a condição de chegada ao laboratório ter sido idêntica em ambas as condições, representando possivelmente estresse antecipatório aos procedimentos ou a estado fisiológico diverso, devido ao intervalo de 7 dias entre os procedimentos.

Entre 0 e 60 minutos os valores de secreção de prolactina são descendentes, sugerindo acoplamento da expressão circadiana do hormônio com o efeito das fases de Relaxamento e do Aprofundamento. A partir daí, coincidente com as fases mais intensas da vivência (entre 60 e 90 minutos), o perfil se altera, tornando-se ascendente, tendência que se manifesta até os 120 minutos (a variação relativa de secreção hormonal é positiva, Figura 17-D).

Não houve sentimento de raiva, como tal, expressa pelo paciente, que pudesse se associar à secreção de prolactina (SOBRINHO, 2003), mas fortes sentimentos de hostilidade voltados contra si mesmo (sentimento de culpa, humilhação, desamparo, sensação de falsidade, hipocrisia, sentimento de autopunição com ameaça de morte e arrependimento) o que, em princípio, poderia equivaler à raiva por si mesmo.

Assim, o perfil da curva de secreção de prolactina na CR indica resposta aos conteúdos da vivência.

5.1.6.5. TSH (Figuras 16-E, 17-E e 18-E): na CC, as flutuações hormonais não são estatisticamente significativas (C-teste, $p=0,65)$ e, na $C R$, são estatisticamente significativas (C-teste, $\mathrm{p}=0,03)$. A diferença entre as médias de secreção entre 0 e 120 minutos, é significativa (Mann-Whitney, U-teste, $\mathrm{p}<0,0001$ ) (Quadro VI). No entanto, entre 45 e 120 minutos, esta diferença não é estatisticamente significativa (Mann-Whitney, U-teste, $\mathrm{p}=0,5200)$.

As curvas de secreção do TSH na CC e na CR se apresentam distintas e exibem valores idênticos na condição de chegada ao laboratório.

$\mathrm{Na} C \mathrm{C}$, a curva é constante não se alterando ao longo do tempo. 
A curva da CR apresenta aumento de secreção do TSH já a partir do instante de chegada e o início dos procedimentos, até os 45 minutos durante as fases de Relaxamento e de Aprofundamento (tal como na prolactina, a representar estresse antecipatório) que é seguido por queda até os 90 minutos, quando, então, as curvas correm paralelamente até o final dos procedimentos.

Os dados observados não são indicativos de resposta do TSH com relação à vivência.

5.1.6.6. GH (Figuras 16-F, 17-F e 18-F): as flutuações hormonais ao longo dos procedimentos não são estatisticamente significativas (C-teste, $\mathrm{p}=0,27$ para a $\mathrm{CC}$ e $\mathrm{p}=0,17$ para a CR). A diferença das médias de secreção hormonal entre 0 e 120 minutos, também não é significativa (Mann-Whitney, U-teste, $\mathrm{p}=0,0690$ (Quadro VI).

A condição de chegada ao laboratório é praticamente a mesma em ambas as condições, valores que se reduzem durante o repouso de 30 minutos.

Na CC, observa-se um pico de secreção aos 75 minutos, após o qual, a secreção de GH permanece ascendente. Na CR, observa-se inicialmente, um pico de secreção hormonal entre os instantes 0 minuto e 15 minutos, seguido por queda intensa até os 30 minutos. Entre 30 e 45 minutos, há uma elevação de $25,00 \%$ na secreção do $\mathrm{GH}$, que se constitui no segmento inicial de onda de secreção do GH que ocorre entre os 30 e os 90 minutos, antecedendo o segmento final da curva de secreção do GH (entre 90 e 120 minutos) que é ascendente. Notese que a maior intensidade da vivência se dá entre os 60 e 90 minutos, culminando com a iminência de morte do sujeito, aos 90 minutos. É a partir dos 30 minutos que a curva da CR se apresenta ascendente, seguindo de perto o perfil de secreção observado na adrenalina (figura $16-\mathrm{C})$.

Tal ocorrência sugere que o GH pode ter respondido à estimulação de receptores alfa-2 adrenérgicos sensibilizados pela adrenalina, como discutido anteriormente. A onda positiva de GH, entre os 30 e 90 minutos, é precedida por uma onda positiva de secreção de TSH que se 
dá entre os 15 e os 60 minutos, o que levanta a hipótese de que essa onda de GH possa também ter se dado como resposta à ação do TRH sobre os somatotrofos da adenohipófise (GIUSTINA; VELDHUIS, 1994).

Assim, a análise qualitativa do fenômeno é apenas sugestiva de que tenha havido resposta do GH à vivência.

5.1.6.7. Resumo: os dados observados indicam ativação do eixo HPA e de secreção de prolactina, e são sugestivos de resposta do GH e da medula supra-renal. 


\subsection{Discussão Geral}

A despeito do limitado número de casos, neste item serão discutidos aspectos gerais representados por alguns fenômenos comuns observados entre os sujeitos e as possíveis relações entre eles.

Todos os sujeitos são do cronotipo matutino (Tabela VII). Portanto, podem ser minimizadas as possíveis diferenças de ritmos de secreção hormonal como fatores de interferência nas respostas observadas.

O Quadro VII resume os resultados obtidos que serão objeto da discussão a seguir, ressaltando-se o fato de que foram utilizados critérios qualitativos e quantitativos para a análise das respostas, conforme discutido anteriormente.

Nos indivíduos responsivos, houve clara relação entre os instantes em que ocorreram as vivências e as alterações de secreção hormonal observadas (Tabela VIII e Figuras), conforme discutido, caso a caso, no item 5.1.

5.2.1. Eixo HPA: (Quadro VII, Figuras 19 a 22, Tabelas VII e VIII).

Os dados indicam ativação do eixo HPA nos sujeitos 1, 2, 5 e 6, são apenas sugestivos no sujeito 3 e negativos no sujeito 4 . Apenas no sujeito 1 os valores atingidos ultrapassaram os limites superiores dos valores de referência para o ensaio. Nos sujeitos 1, 2 e 6 observou-se o fenômeno de atraso fisiológico esperado entre o estímulo do ACTH e a resposta do cortisol (MILUK-KOLASA et al., 1994). No sujeito 3 não foi observada resposta do cortisol a despeito da curva do ACTH ter sido sugestiva de resposta ao estresse. Este fato pode representar um tipo específico de resposta do eixo HPA observado no TEPT (YEHUDA et al., 1995; RESNIK et al., 1995).

Todas as vivências foram de natureza adversa (Tabela VIII) e representando novidade (memórias traumáticas nunca recuperadas antes), constituindo situações equivalentes a estímulos agudos, o que provoca estimulação do eixo HPA, diferentemente do que se observa 
Quadro VII - Sumário das respostas hormonais à RecMem nos 6 sujeitos

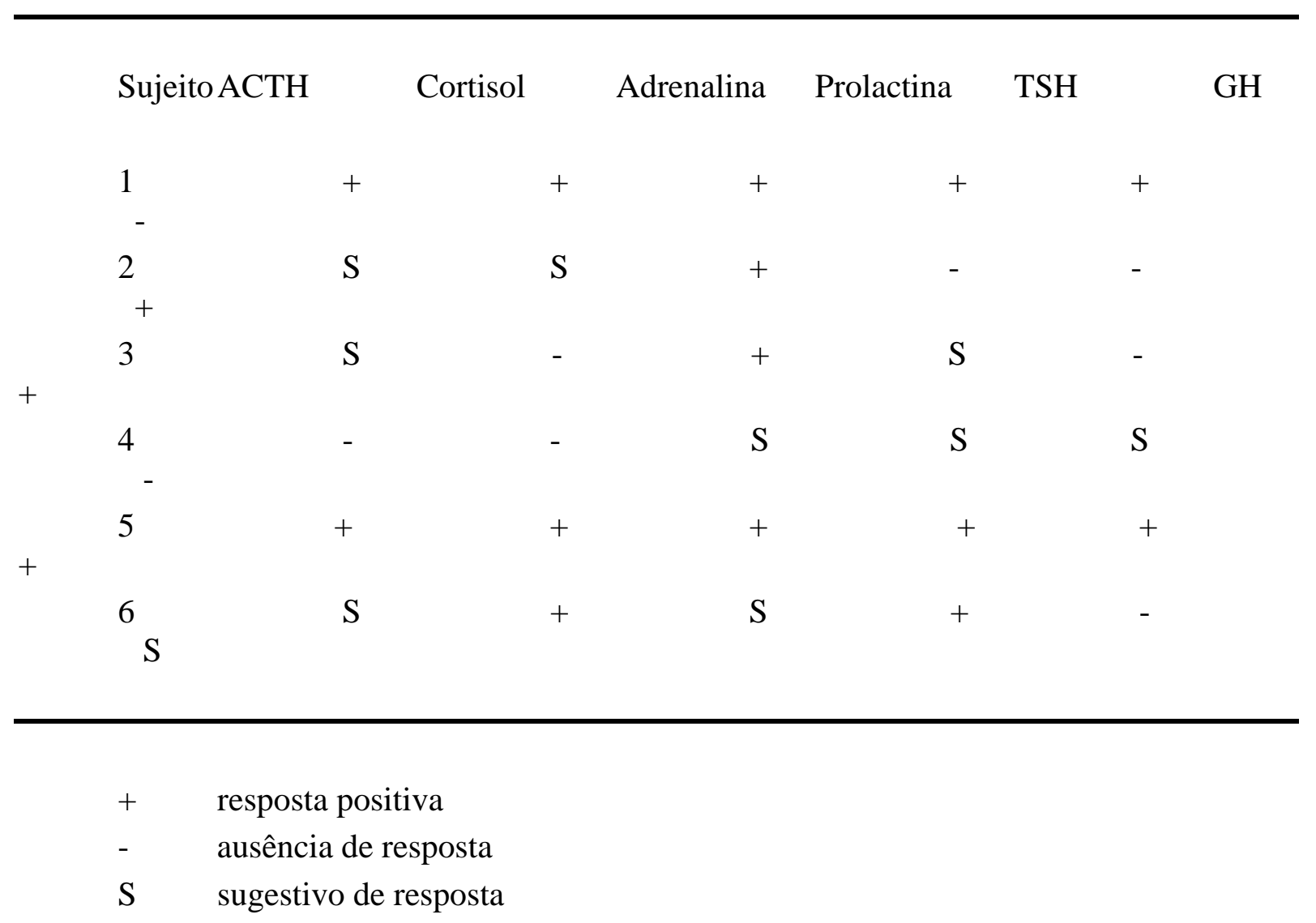


1

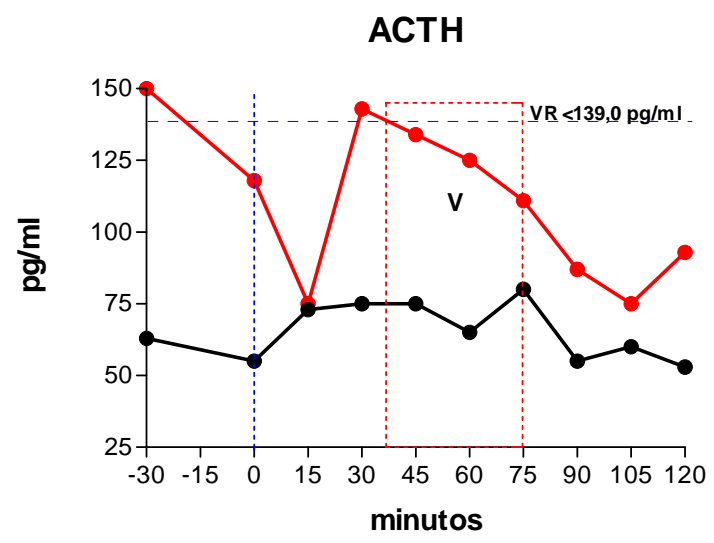

2

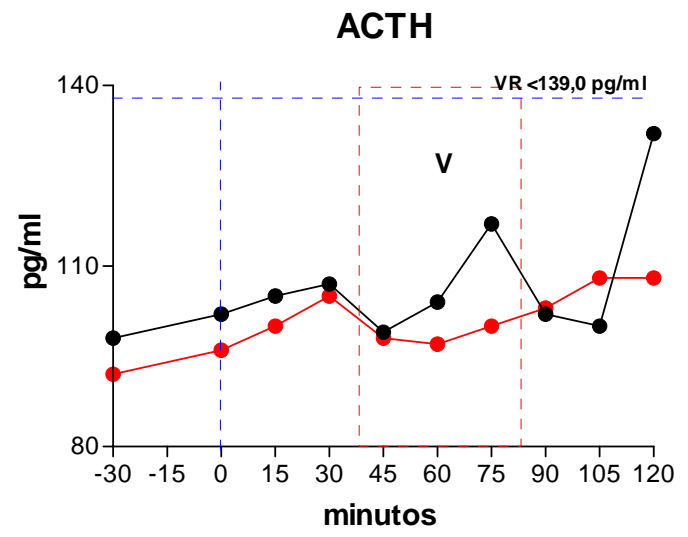

5

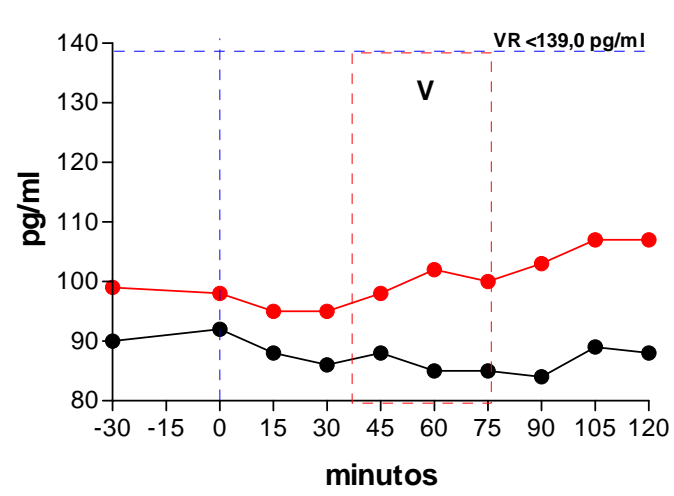

2

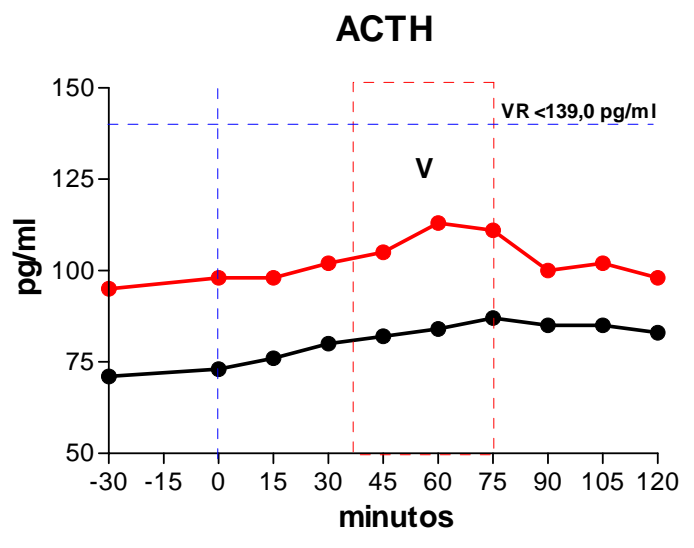

4

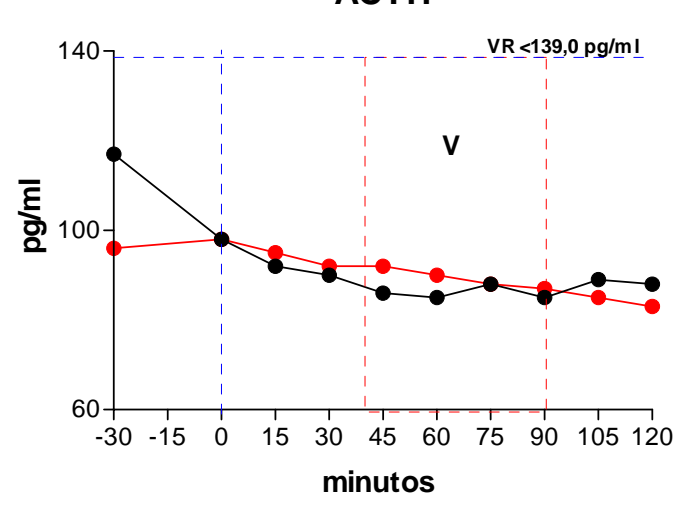

6

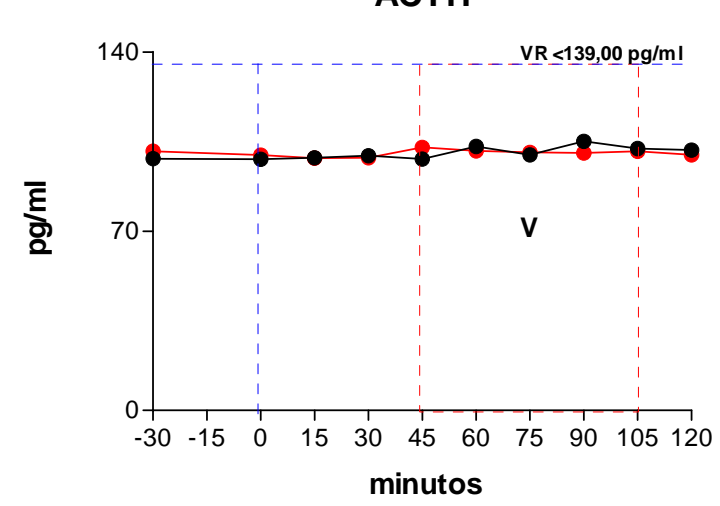

Figura 19 - curvas de tempo e resposta das variações do ACTH nos 6 sujeitos submetidos à recuperação de memórias traumáticas, .

$\bullet-\bullet$ - condição controle (CC).

$\bullet-\bullet$ - condição de recuperação (CR).

V - vivência.

VR - valores de referência para o ensaio 


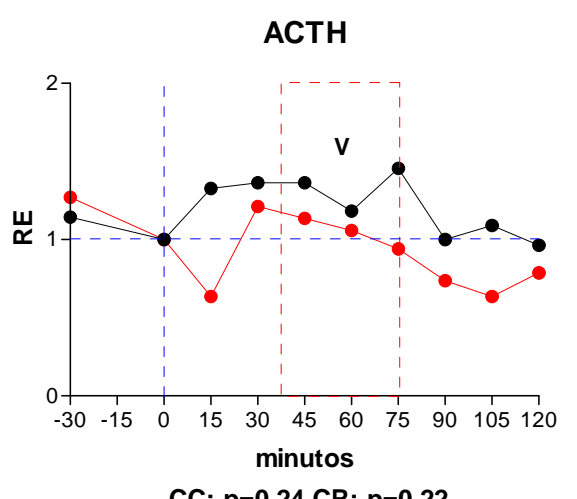

3

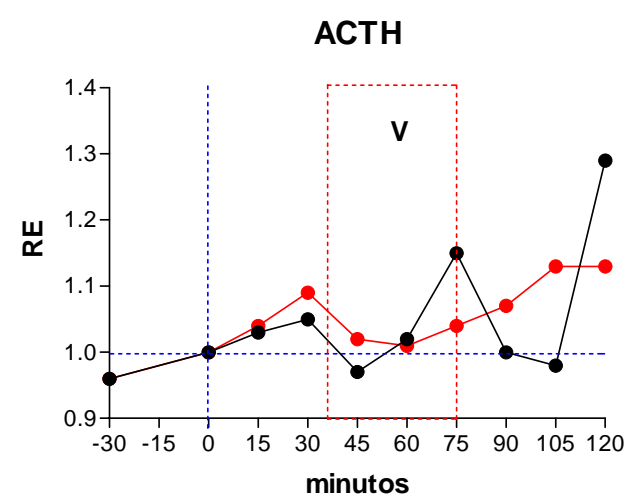

CC: $p=0,31$ CR: 0,02

5

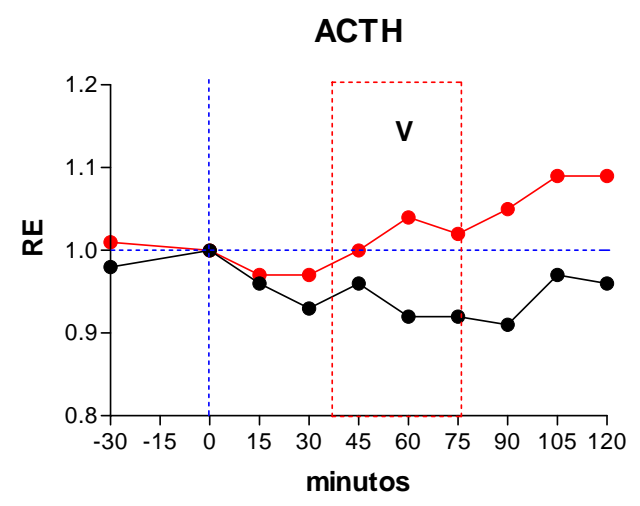

CC: $p=0,09$ CR: $p=0,00$
2

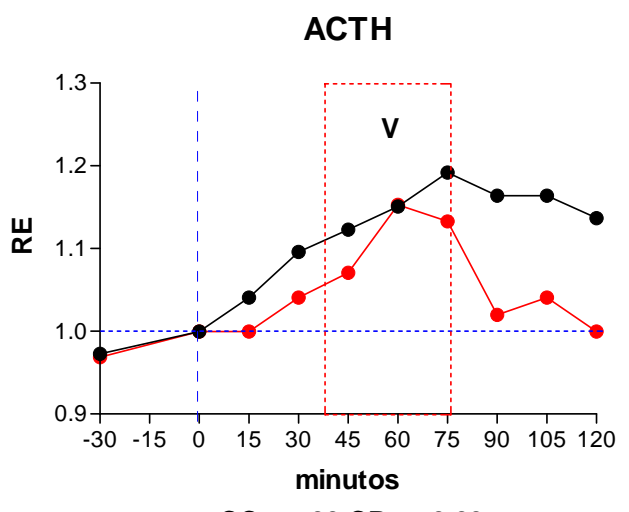

4

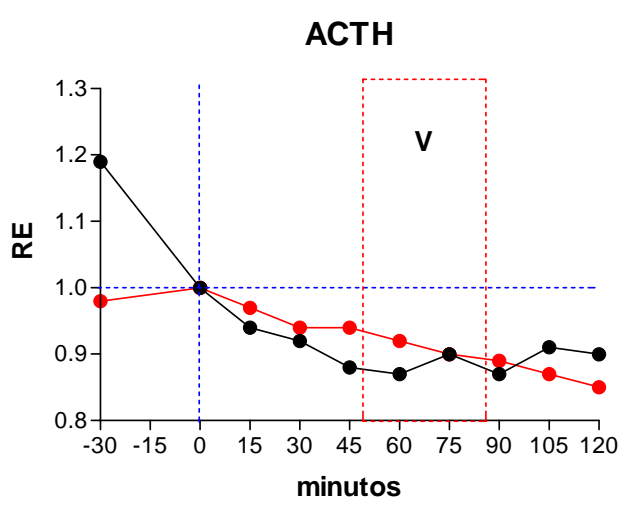

CC: $p=0,00$ CR: $p=0,00$

6

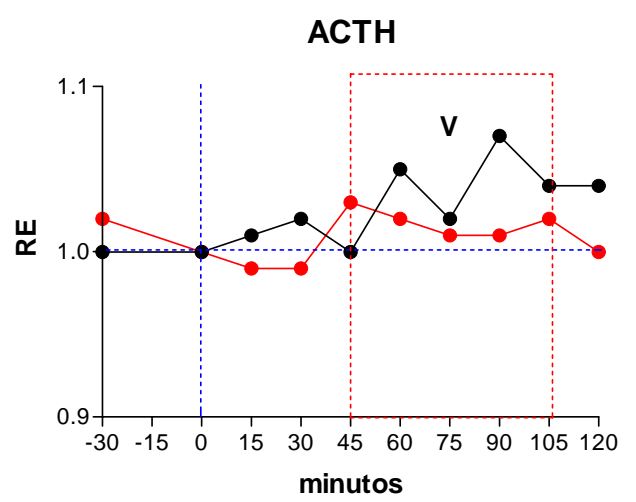

CC: $p=0,09$ CR: $p=0,00$

Figura 20 - curvas rescalonadas de tempo e resposta do ACTH nos 6 sujeitos submetidos à recuperação de memórias traumáticas.

$\bullet-\bullet$ - condição controle (CC).

•-• - condição de recuperação (CR).

V - vivência. 
1

CORTISOL

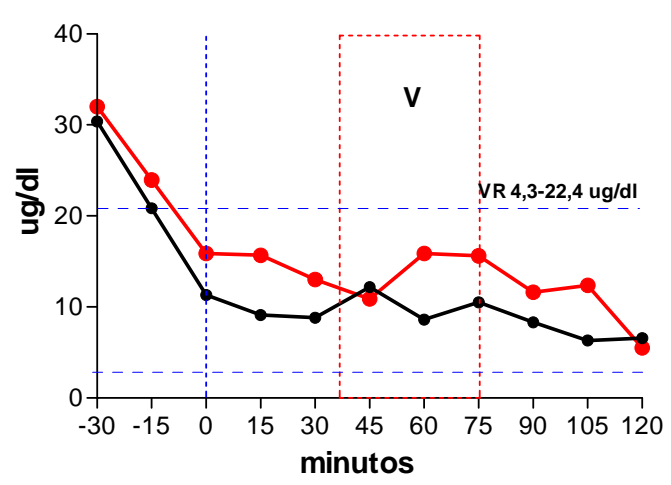

3

CORTISOL

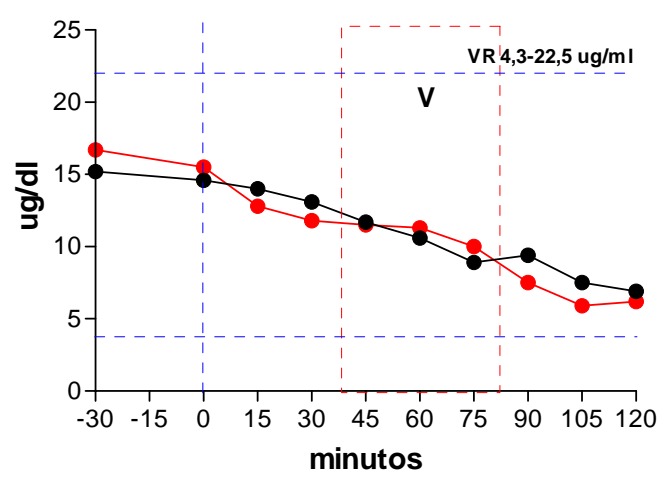

5

CORTISOL

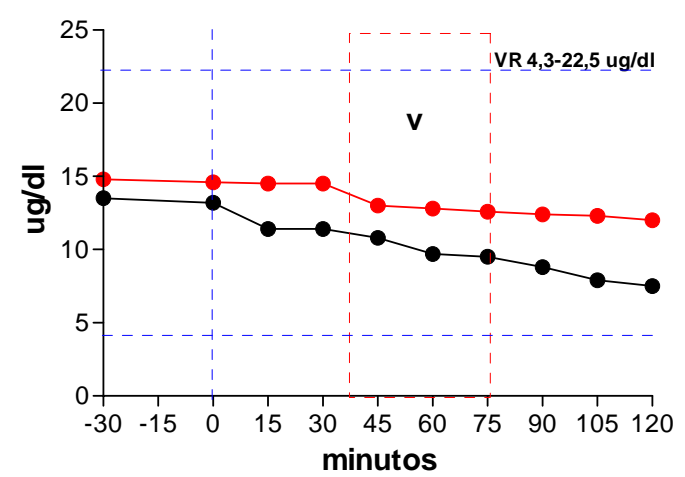

2

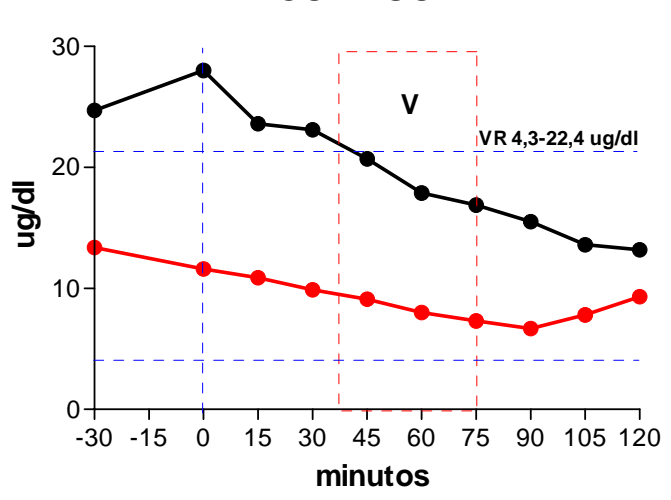

4

CORTISOL

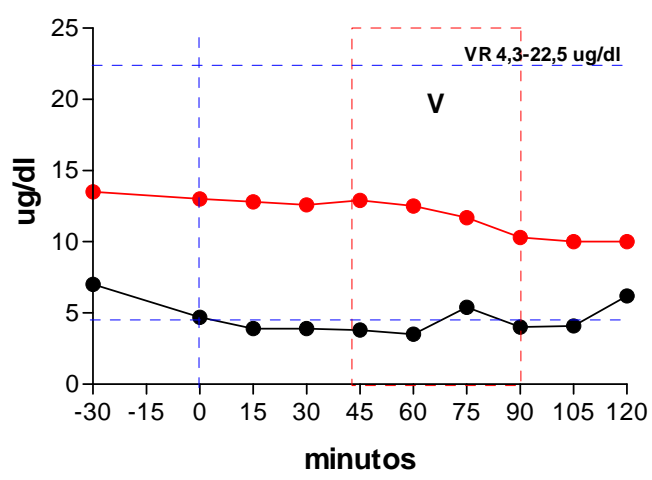

6

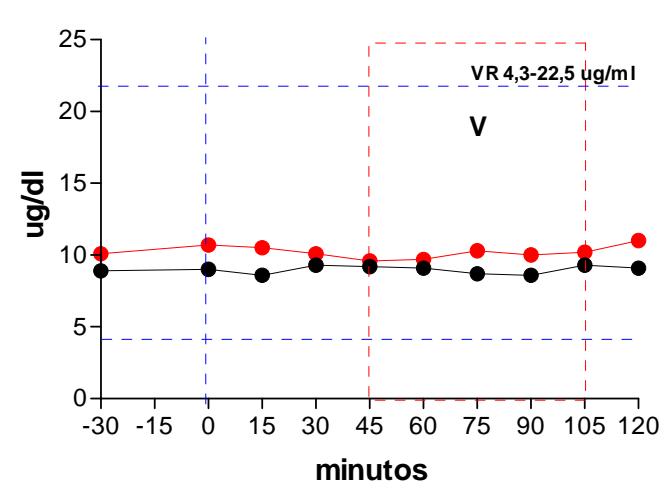

Figura 21 - curvas de tempo e resposta das variações do cortisol nos 6 sujeitos submetidos à recuperação de memórias traumáticas, .

$\bullet-\bullet$ - condição controle (CC).

$\bullet-\bullet$ - condição de recuperação (CR).

V - vivência.

VR - valores de referência para o ensaio 
1

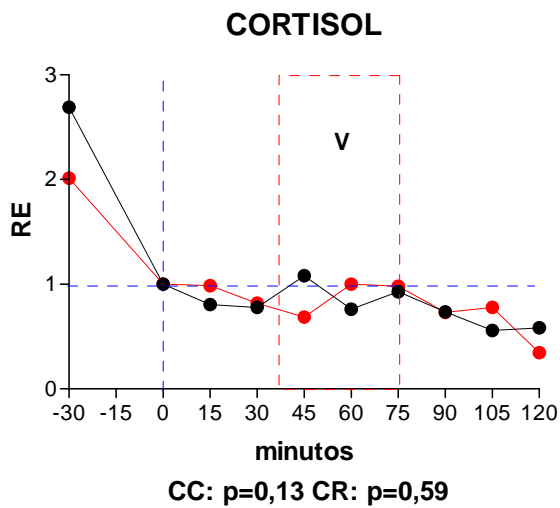

3

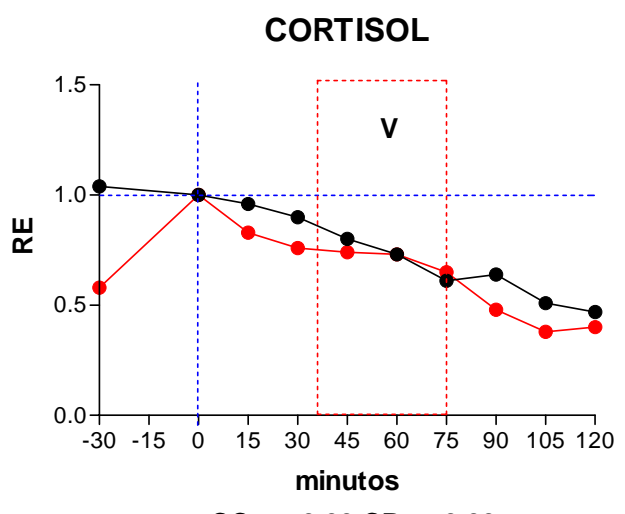

5

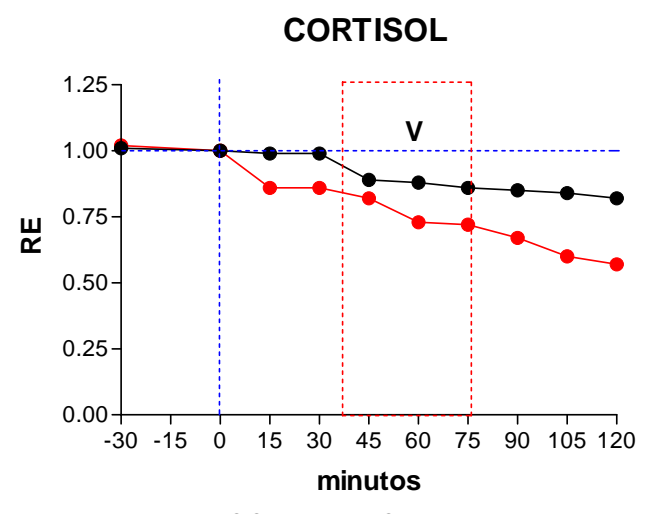

CC: $p=0,00$ CR: $p=0,00$
2

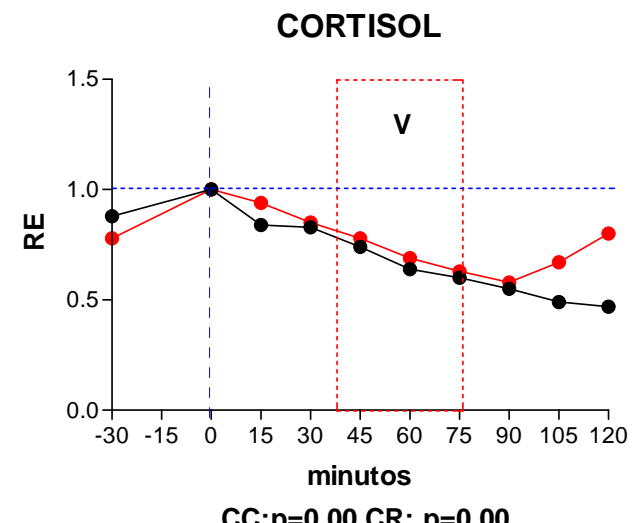

4

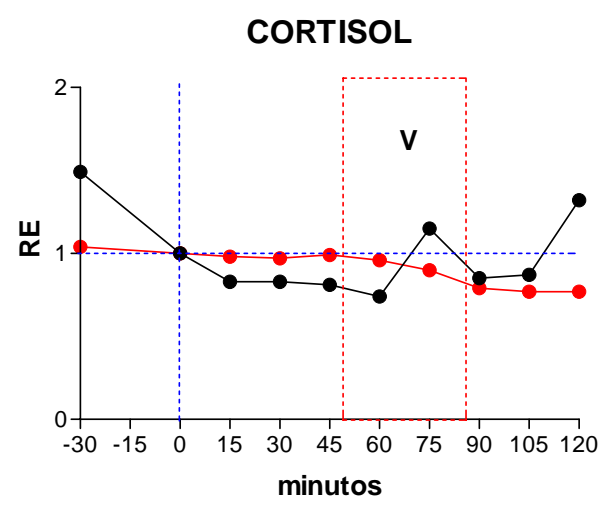

CC: $p=0,32$ CR: $p=0.00$

6

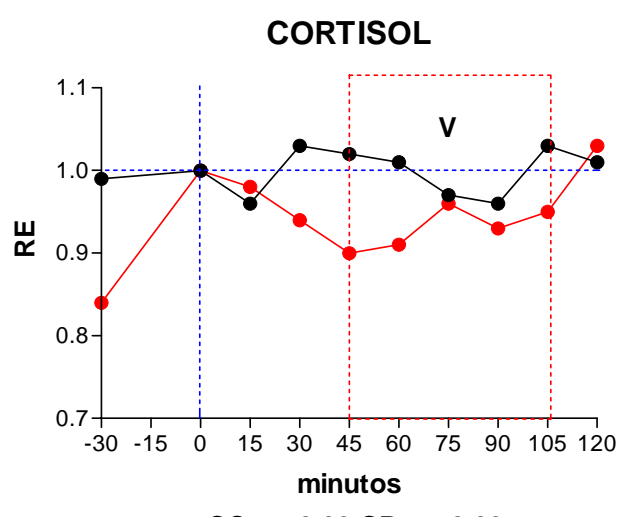

CC: $p=0,00$ CR: $p=0,00$

Figura 22 - curvas rescalonadas de tempo e resposta do cortisol nos 6 sujeitos submetidos à recuperação de memórias traumáticas.

$\bullet-\bullet$ - condição controle (CC).

$\bullet-\bullet$ - condição de recuperação (CR).

V - vivência. 
diante de estímulos crônicos (GANN, 1969), onde a resposta do córtex adrenal está, inclusive, reduzida. Nenhum dos sujeitos havia experimentado anteriormente as mesmas vivências, quer espontaneamente, quer artificialmente, o que caracteriza a novidade e exclui o fenômeno de habituação como elemento fisiológico de redução da resposta ao estresse (WÜST et al., 2005), particularmente no TEPT (YEHUDA et al., 1995; RESNIK et al., 1995). Assim, a experiência prévia do sujeito aos procedimentos de Rec-Mem não pode ser arrolada como fator de inibição da resposta.

O fenômeno de habituação poderia teoricamente ser evocado nos sujeitos 2 e 6 , portadores de FSO (Fobia Social - DSM-IV-300.23) (Tabela VII), dado o caráter da recorrência constante do distúrbio. No entanto, ambos apresentaram resposta compatível com estimulação do eixo HPA.

Os sujeitos 1 e 5, portadores de TAG (Transtorno de Ansiedade Generalizada - DSMIV 300.02) foram os que apresentaram respostas mais características, o que é compreensível, dado sua maior excitabilidade.

Somente o sujeito 4 não exibiu resposta do eixo HPA. Apresentou-se sem diagnóstico pelos critérios do SCID/DSM-IV, sem pontuação indicativa de ansiedade (HAM-A 0) e de depressão (BDI 8). Vivenciou tristeza, raiva, solidão e impotência em sua vivência. O medo foi emoção não compartilhada com ou outros sujeitos. É possível que a ausência de resposta do eixo HPA (assim como as respostas apenas sugestivas, porém não conclusivas, de secreção de adrenalina, prolactina e TSH, e ausência de resposta do GH, conforme será discutido a seguir), tenham se devido a características individuais do sujeito, da sua percepção subjetiva da vivência experimentada (PERES et al., 2005), do seu estado de auto-estima (PRUESSNER et a., 1999) e/ou a níveis mais baixos de estimulação neurofisiológica.

A resposta neurofisiológica ao estresse envolve complexas reações dentro do sistema nervoso central, tal como discutido anteriormente, onde o sistema CRH se constitui no seu 
elemento fundamental (TSIGOS; CHROUSOS, 2002) tanto para a resposta autonômica quanto para o eixo HPA. Assim, deve ser ressaltada a natureza sistêmica da resposta (BIONDI; PICARDI, 1999), onde a percepção subjetiva do elemento estressor é fundamental e a possível explicação do seu caráter individual (PERES et al., 2005). Outra explicação possível para a ausência de resposta do eixo HPA neste sujeito seria uma maior sensibilidade aos efeitos inibitórios da música, tal como referido na literatura, incluindo a preferência individual (CHAFIN et al., 2004; FUKUI; YAMASHITA, 2003; KHALFA et al., 2003; PELLETIER, 2004; RIDER et al., 1985; UEDO et al., 2004). Adicionalmente, a alteração do estado de alerta ou de consciência obtidos pelo relaxamento assistido, como parte da técnica utilizada para a Rec-Mem pode, teoricamente, ser arrolada como fator inibitório (MIGNEAULT et al., 2004), apesar deste autor ter realizado seu experimento em sujeitos anestesiados.

5.2.2. Adrenalina: (Quadro VII, Figuras 23 e 24, Tabelas VII e VIII).

Os resultados obtidos confirmam, para os procedimentos de Rec-Mem, as observações de Walter Cannon, no início do século passado (o medo, emoção que sinaliza ameaça, foi comum a todos os sujeitos, com exceção do sujeito 4), e indicam resposta da medula suprarenal nos sujeitos 1,2,3 e 5, e são sugestivos nos sujeitos 4 e 6 , em alguns casos atingindo ou ultrapassando os limites superiores dos valores de referência para o ensaio (sujeitos 1, 2 e 3).

Um dado interessante é o representado pela inversão de resposta entre o eixo HPA e a medula suprarenal, conforme já referido no item 5.1. Observou-se atraso de secreção de adrenalina em relação ao $\mathrm{ACTH}$, quando seria de se esperar o oposto: como resposta ao estresse, ocorre rápida ativação autonômica seguida por excitação mais lenta do eixo HPA (WOLF, 2003); isto é, analogicamente, tudo se passa como se a resposta autonômica representasse a mudança de um canal de televisão para outro, ou seja, a mudança de um 
1

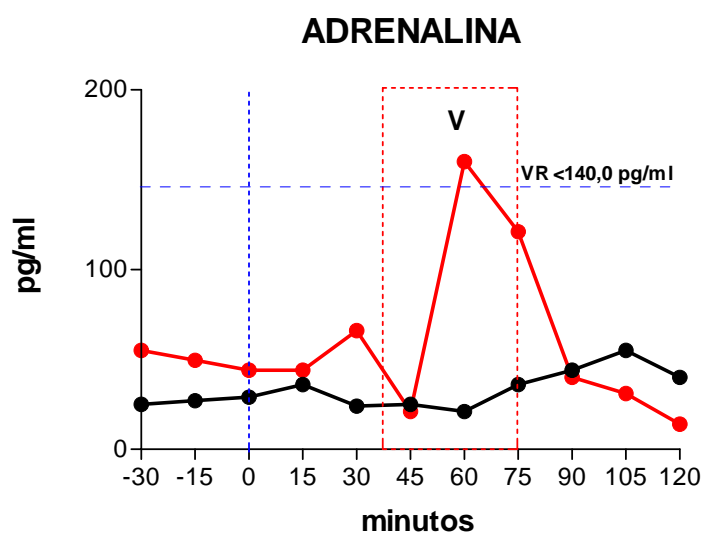

3

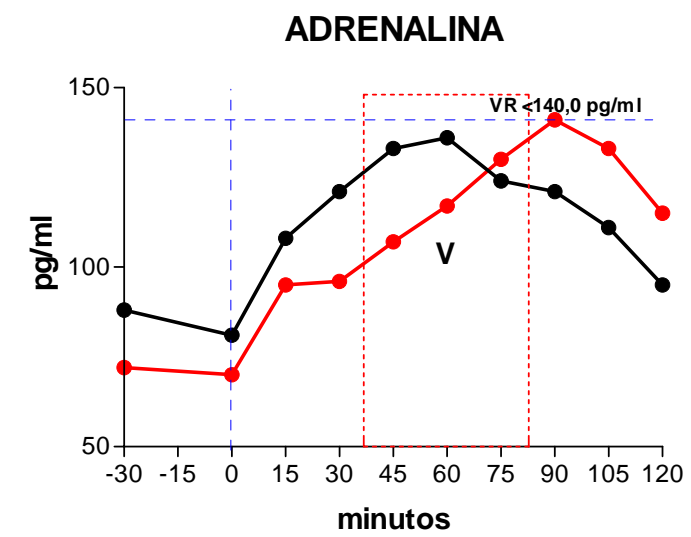

5

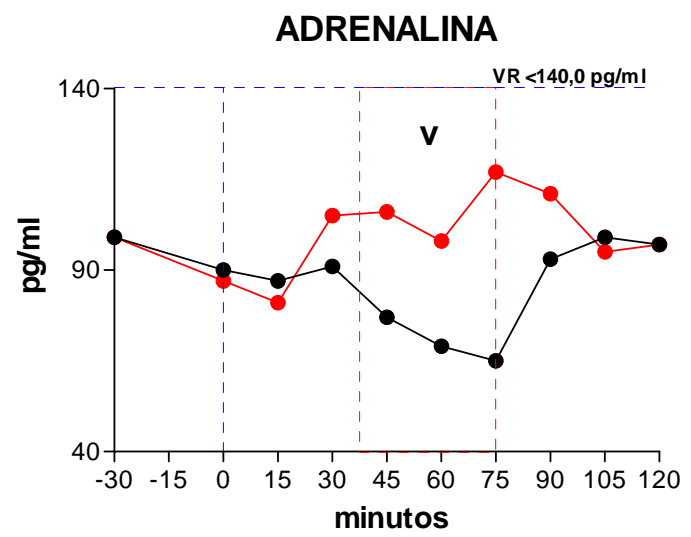

2

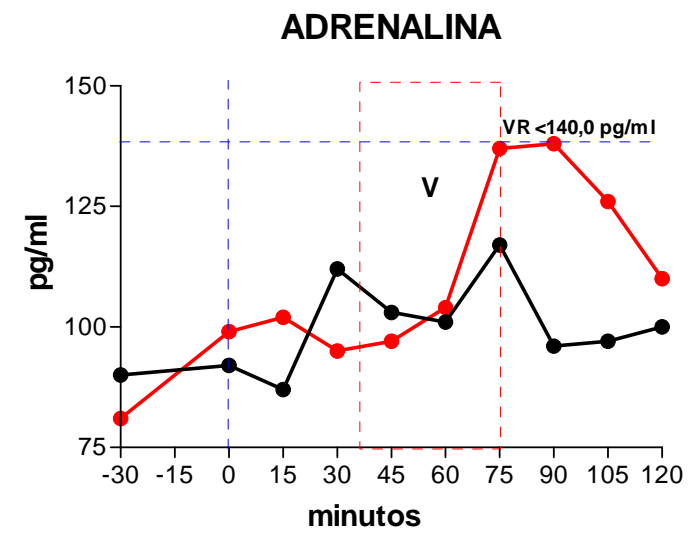

4

ADRENALINA

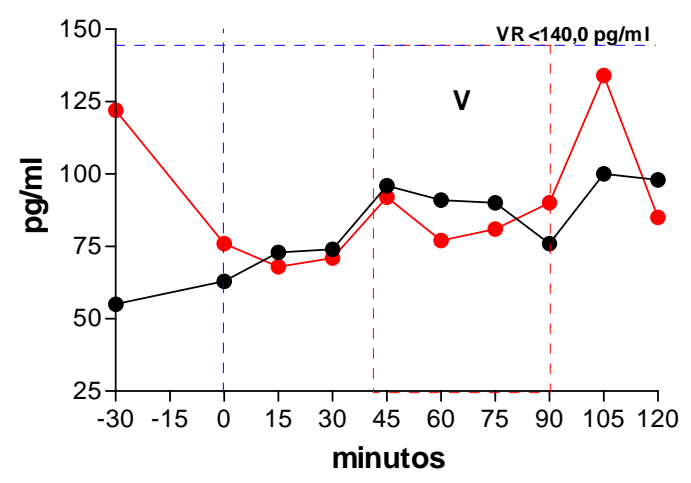

6

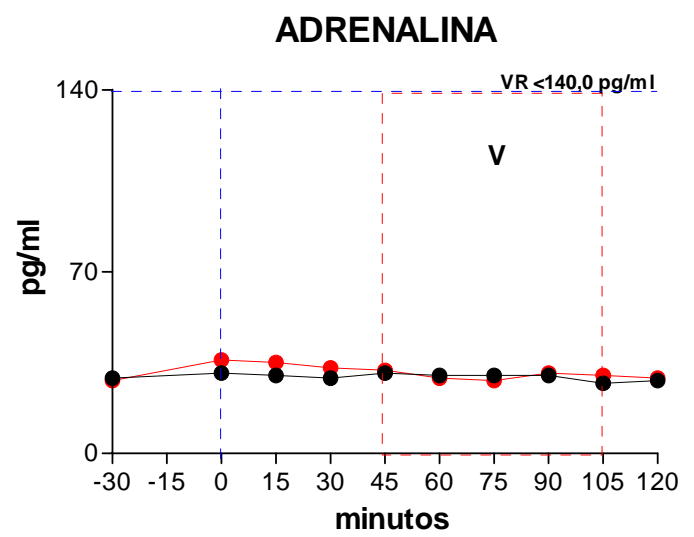

Figura 23 - curvas de tempo e resposta das variações do adrenalina nos 6 sujeitos submetidos à recuperação de memórias traumáticas.

$\bullet-\bullet$ - condição controle (CC).

$\bullet$ - - condição de recuperação (CR).

V - vivência.

VR - valores de referência para o ensaio 
1

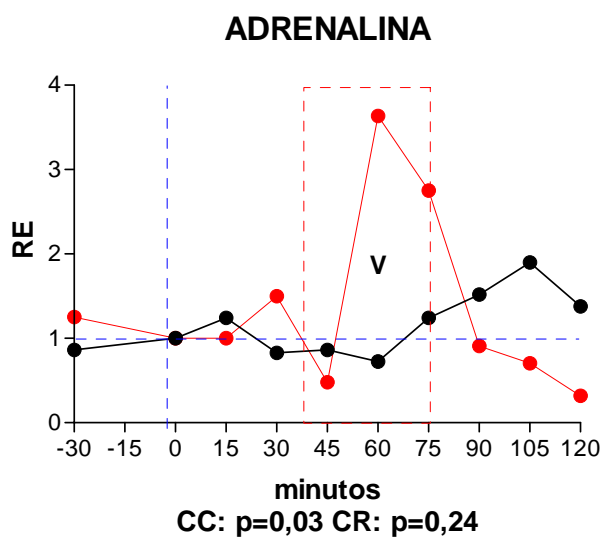

3

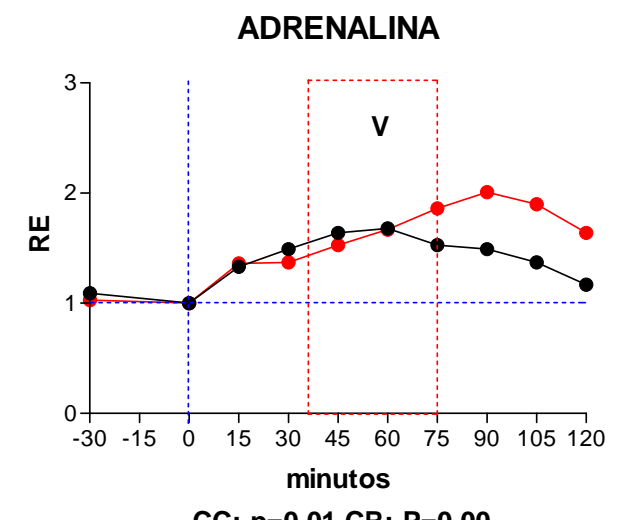

CC: $p=0,01$ CR: $P=0,00$

5

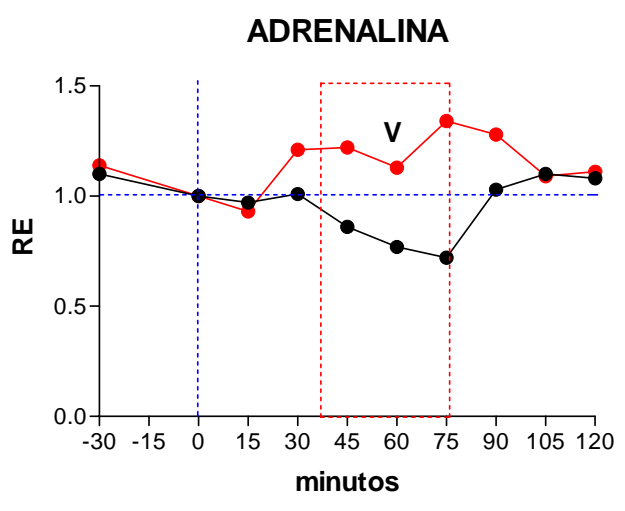

CC: $p=0,04$ CR: $p=0,11$
2

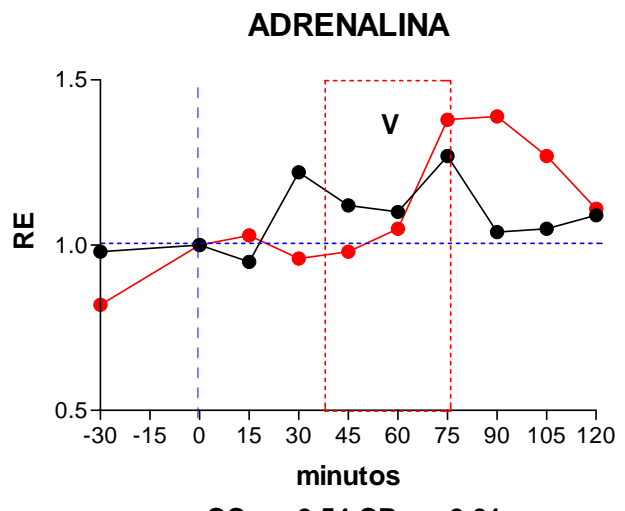

CC: $p=0,54$ CR: $p=0,01$

4

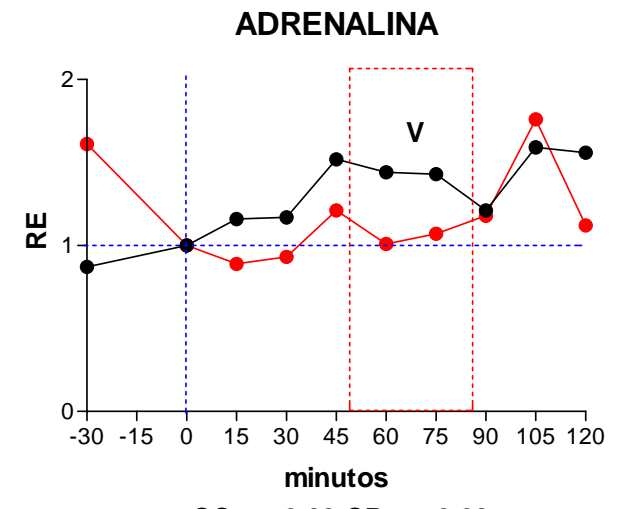

CC: $p=0,03$ CR: $p=0,28$

6

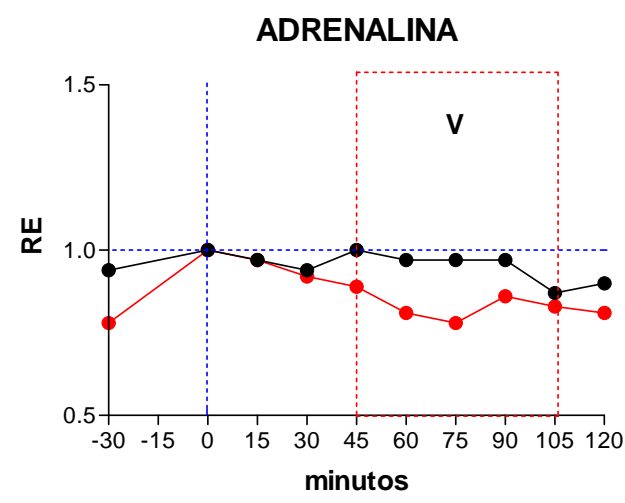

CC: $p=0,04$ CR: $p=0,11$

Figura 24 - curvas rescalonadas de tempo e resposta de adrenalina nos 6 sujeitos submetidos à recuperação de memórias traumáticas.

•-• - condição controle (CC).

$\bullet$-• - condição de recuperação (CR).

V - vivência. 
estado de alerta para outro (URSIN e ERIKSEN, 2003), ação facilitadora da tomada de decisão e de sua execução e, em seguida, o sistema neuroendócrino faria o que se faz quando se realiza o ajuste fino para melhorar a qualidade da imagem.

Com efeito, essa inversão pode ser devida a estímulo temporalmente diferenciado dos neurônios do sistema CRH. A ativação de neurônios extra-hipotalâmicos que expressam o CRH pode não ser concomitante ao das células neurosecretoras do hipotálamo (GRAEFF, 2003) e a própria expressão gênica do CRH nos neurônios que constituem a via de saída do sistema hipocampo-amigdalóide (núcleo central da amigdala e no núcleo instersticial da stria terminalis) parece estar temporalmente dissociada da observada no núcleo paraventricular (SCHULKIN et al., 1998).

Não é possível se concluir pela razão da ocorrência desta inversão no presente estudo. Mas é possível se especular sobre a emergência dos conteúdos traumáticos (previamente estocados sob a forma de memórias traumáticas) estimulando a resposta neuroendócrina mesmo antes que haja a estimulação autonômica pelo CRH.

Com efeito, diante de uma ameaça externa ao sujeito, a emoção gerada se dá através da estimulação do sistema hipocampo-amigdalóide e retransmissão do sinal por meio de suas densas conexões com o neocórtex: gera-se, por meio deste circuito, sinais que irão constituir o componente emocional da vivência.

O processo de transmissão de informações a serem estocados sob a forma de memórias nas áreas associativas polimodais do neocórtex a partir do hipocampo é mais lento, e subseqüente à vivência e à emoção por ela gerada, assim como depende da atividade do Sistema LC/NA (Locus ceruleus-noradrenérgico-autonômico), cujos neurônios são importantes para os fenômenos que determinam a formação e a consolidação da memória. Como na Rec-Mem o material já está estocado sob a forma de memória e é simplesmente evocado, talvez este fato possa explicar a inversão observada: o sinal, a partir do sistema de 
saída do complexo hipocampo-amigdalóide (núcleo intersticial da stria terminalis com suas conexões com o hipotálamo, o que inclui a resposta comportamental CRH-mediada pela substância cinzenta periaquedutal dorsal e ventral, assim como as conexões serotonérgicas entre o núcleo central da amigdala e a rafe dorsal e daí para os núcleos para-ventriculares), se daria antes da estimulação CRH-mediada dos núcleos autonômicos responsáveis pela resposta da medula supra-renal.

Os presentes dados confirmam, assim, a existência do desacoplamento temporal dos disparos dos neurônios que compõem o sistema CRH.

É possível, também, sua associação com estados que se apresentam como um TEPT parcial. Com efeito, no continuum que vai da normalidade à manifestação plena do transtorno existem estados intermediários (TEPT sub-clinico ou parcial), com anormalidades da resposta do eixo HPA (YEHUDA et al., 1995; RESNIK et al., 1995) associados à hiperexcitabilidade autonômica. A prevalência destes estados intermediários parece ser de aproximadamente $30 \%$ (WEISS et al., 1992).

Outro fato a ser considerado, como já discutido anteriormente, é que a ativação do eixo HPA pode provocar, secundariamente, aumento da secreção de adrenalina pela medula suprarenal, incrementando a resposta resultante da estimulação autonômica. Isto é, a participação da secreção do cortisol como agente estimulador da síntese de adrenalina, que se dá por meio da sua difusão pelo sistema porta córtico-medular e subseqüente estimulação da feniletanolamina-N-metil transferase (PNMT), enzima que controla a síntese de adrenalina a partir da noradrenalina (WURTMAN, 2002).

5.2.3. Prolactina (Quadro VII, Figuras 25 e 26, Tabelas VII e VIII).

No presente estudo, reforçando a idéia da participaçãp da prolactina na sobrevivência do indivíduo por meio de seu papel na homeostasia, os dados obtidos indicam resposta da 
1

PROLACTINA

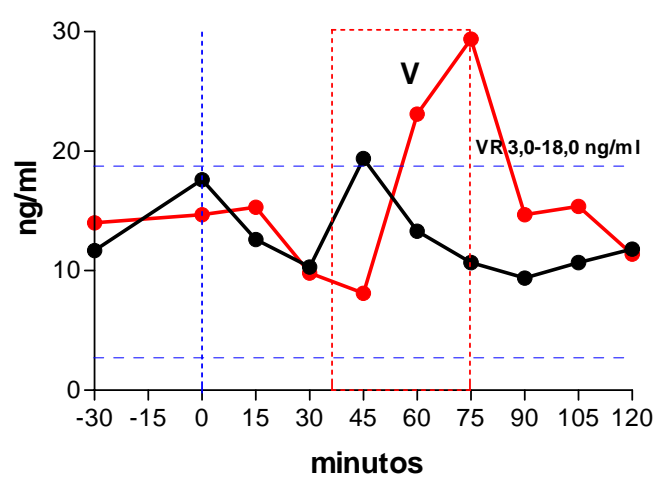

3

PROLACTINA

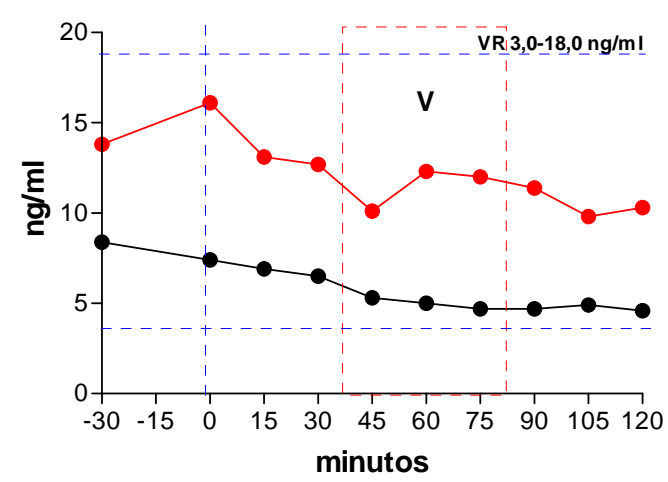

5

PROLACTINA

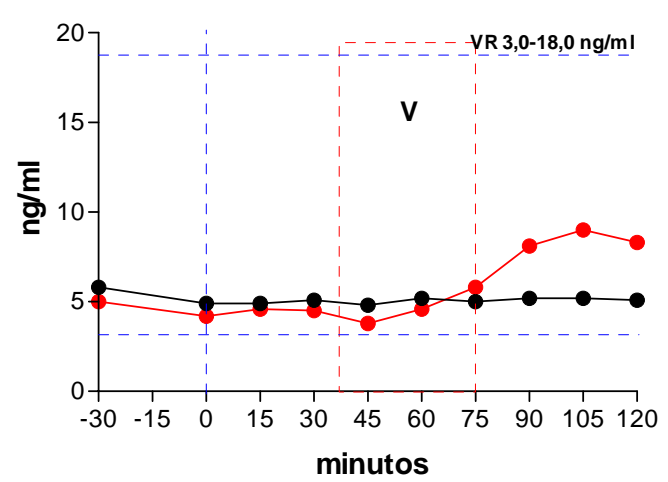

2

PROLACTINA

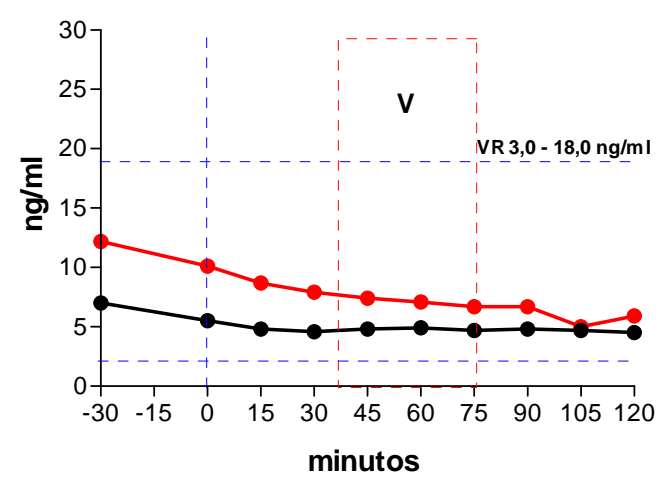

4

PROLACTINA

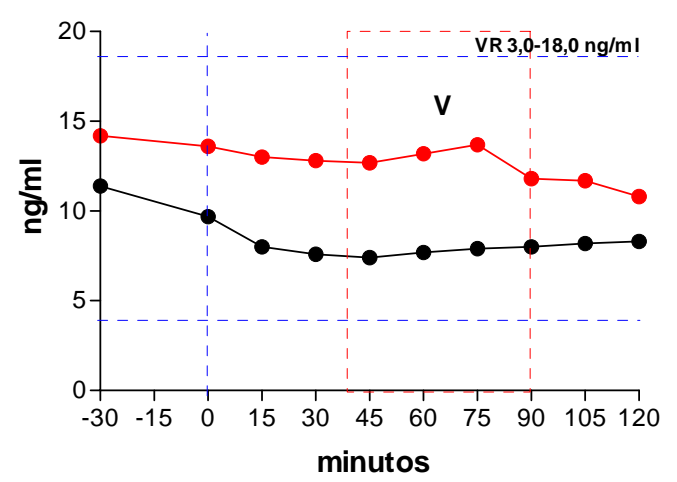

6

PROLACTINA

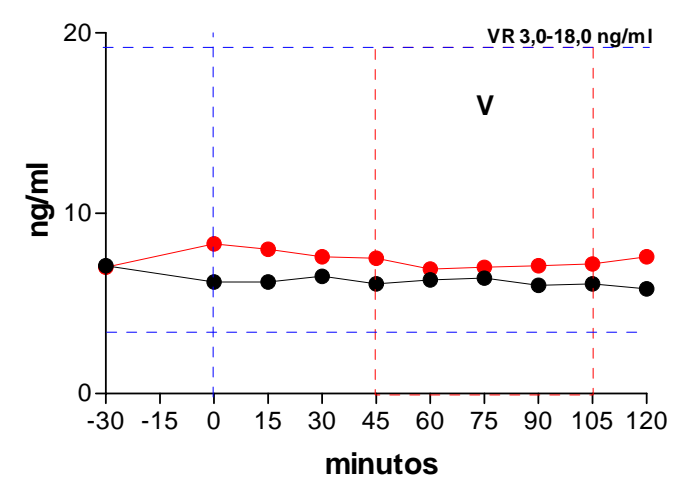

Figura 25 - curvas de tempo e resposta das variações de prolactina dos 6 sujeitos submetidos à recuperação de memórias traumáticas, .

•-• - condição controle (CC).

$\bullet-\bullet$ - condição de recuperação (CR).

V - vivência.

VR - valores de referência para o ensaio 
1

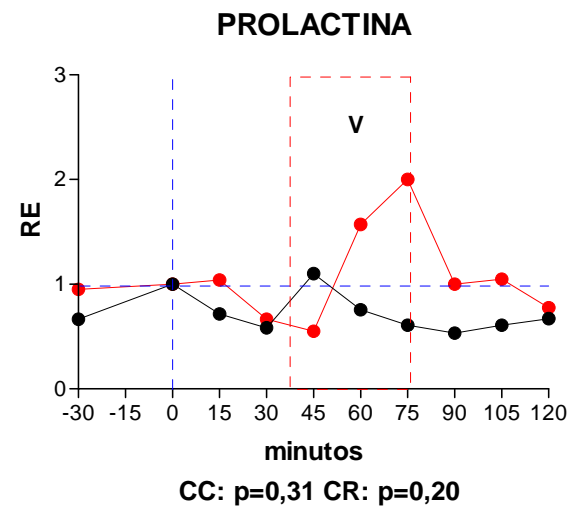

3

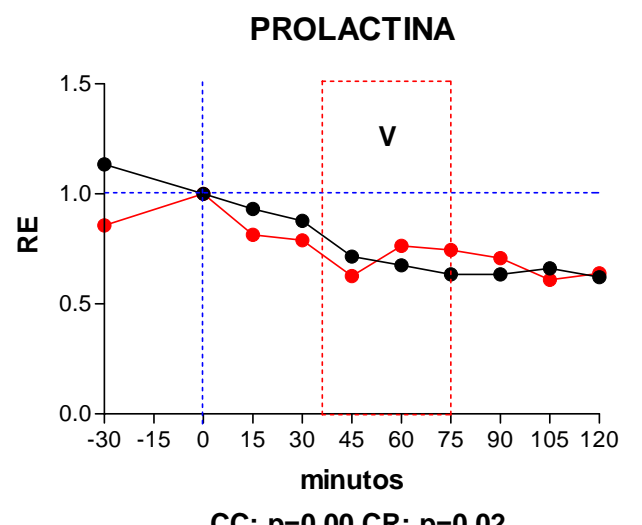

CC: $p=0,00$ CR: $p=0,02$

5

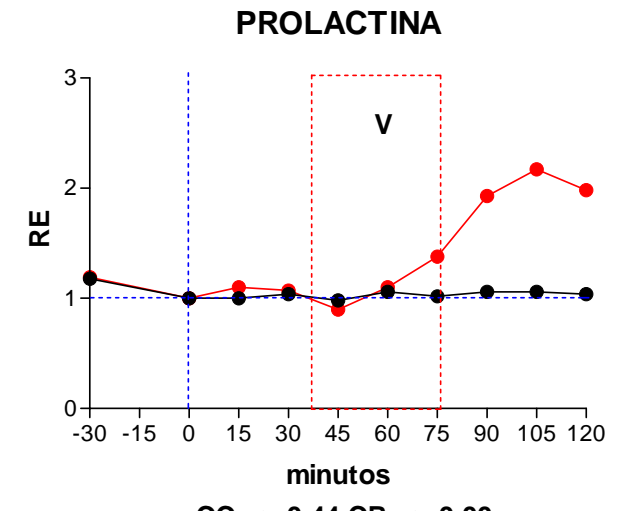

CC: $p=0,44$ CR: $p=0,00$
2

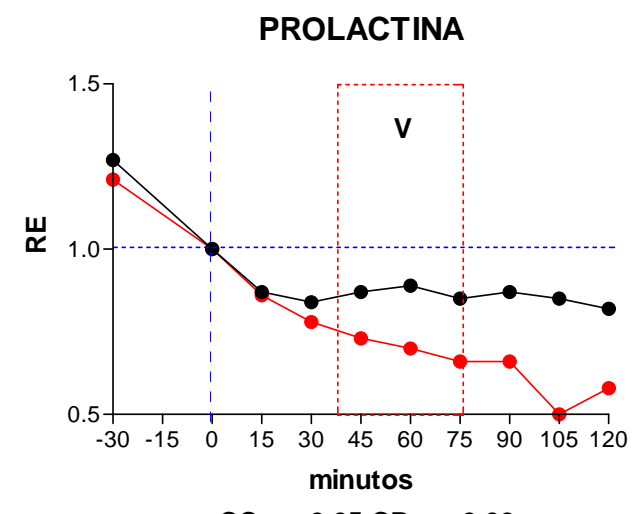

4

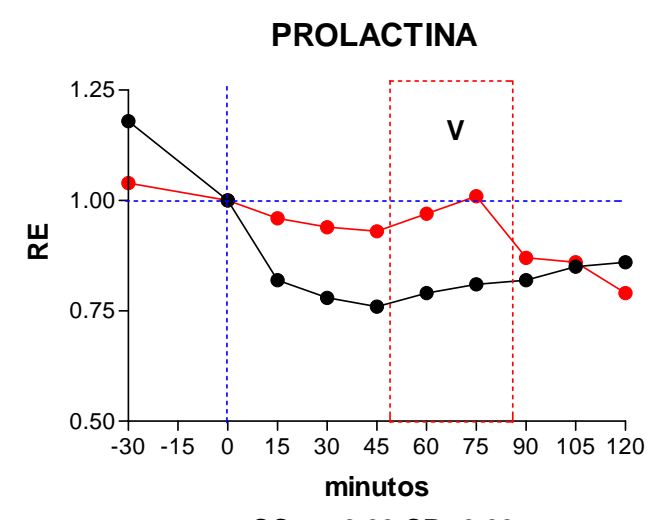

CC: $p=0,00$ CR: 0,02

6

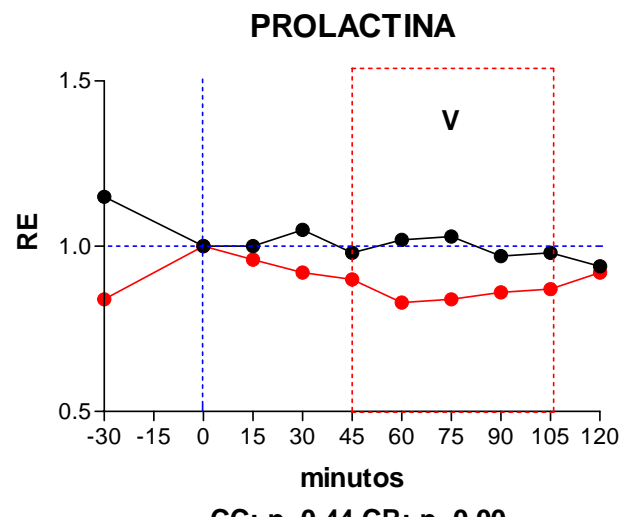

Figura 26 - curvas rescalonadas de tempo e resposta de prolactina nos 6 sujeitos submetidos à recuperação de memórias traumáticas.

$\bullet$-• - condição controle (CC).

•-• - condição de recuperação (CR).

V - vivência. 
prolactina ao estresse representado pela vivência nos sujeitos $1,3,5$ e 6 , e são sugestivos de resposta no sujeitos 4 .

No sujeito 1 a secreção hormonal ultrapassa os limites superiores dos valores de referência para o ensaio, fato que não se repetiu em nenhum dos outros sujeitos. Nos responsivos existiu clara relação entre a resposta e a manifestação temporal da vivência, com elevação da secreção hormonal sempre a partir dos 45 minutos dos procedimentos, com exceção do sujeito 6, que exibe liberação mais tardia, a partir dos 60 minutos. Nos sujeitos 3 e 4, apenas sugestivos de resposta, manteve-se o padrão de elevação a partir dos 45 minutos. Este fato pode ser teoricamente explicado pelos instantes de coleta do material, realizada a cada 15 minutos; o instante do início da elevação de secreção hormonal pode ter se dado entre coletas e só identificado subseqüentemente.

O limitado número de casos não permite estabelecer relações entre as respostas observadas e os diagnósticos obtidos pelos testes realizados previamente ao experimento.

A relação entre o tipo específico de emoção e os sentimentos experimentados (raiva e humilhação) e a secreção de prolactina, mas não com outros estados emocionais, é sugerida nos sujeitos 1,5 e 6 , responsivos, e 3 e 4 , sugestivos de resposta, particularmente associado à raiva, o que parece confirmar os dados da literatura (SOBRINHO, 2003).

Somente o sujeito 2 não apresentou nenhuma resposta de prolactina e, coincidentemente, foi o único sujeito que não experimentou o sentimento de raiva durante a vivência, conforme mostra a Tabela VIII. Os dados obtidos pelo presente trabalho não explicam conclusivamente a ausência de resposta; ressalte-se que apresentou respostas positivas envolvendo adrenalina e GH, e sugestiva para o eixo HPA.

É possível, assim, que a ausência de resposta da prolactina tenha se devido a características individuais do sujeito, da sua percepção subjetiva da vivência experimentada, e/ou a níveis diferentes de estimulação neurofisiológica. 
5.2.4. TSH (Quadro VII, Figuras 27 e 28, Tabelas VII e VIII).

Os dados obtidos indicam resposta de secreção do TSH nos sujeitos 1 e 5, no sujeito 4 são apenas sugestivos, observando-se ausência de resposta nos sujeitos 2, 3 e 6 .

Os sujeitos 1 e 5 eram portadores de TAG (SCID/DSM-IV 300.02), os sujeitos 3 e 4 não apresentavam diagnóstico, os sujeitos 2 e 6 eram portadores de FSO (SCI/DSM-IV 300.23). Isto pode significar maior incidência de resposta em indivíduos portadores de ansiedade generalizada do que nos demais.

A secreção fisiológica do TSH obedece a um reconhecido ritmo circadiano semelhante ao do cortisol, além de apresentar pequenos picos de secreção a cada 80 a 180 minutos, provavelmente devidos a descargas hipotalâmicas de TRH.

A resposta do TSH ao estresse é contraditória na literatura, conforme discutido anteriormente. Alterações de temperatura ambiente têm influência sobre a secreção do TSH: o frio estimula, o calor inibe. Alterações da secreção do TSH observadas no estresse têm sido debitadas ao metabolismo periférico do T4 (CHAN et al., 1978), mediante deslocamento de suas proteínas transportadoras, ou devido à ação de aminas biogênicas (LANGER et al., 1983). O estresse crônico também é capaz de induzir mudanças da secreção do TSH e do GH, possivelmente devido à liberação dos seus hormônios reguladores hipotalâmicos (ARMARIO, 1984; ARMARIO, 1987). Em humanos submetidos a estresse agudo durante a prática do paraquedismo também se observou elevação do TSH, sendo que esta resposta não foi afetada pela experiência prévia do indivíduo (SCHEDLOWSKI et al., 1992), isto é, não sofre o fenômeno de habituação. A elevação de TSH plasmático em humanos submetidos ao estresse de exames acadêmicos sugere existir diferença sexual da resposta do eixo hipófiso-tireoidiano ao estresse psicológico (JOHANSSON et al., 1987).

No item 5.1, para os sujeitos 2,3 e 4, foram feitas considerações teóricas sobre o TEPT relativas ao eixo HPA como explicações possíveis de seu padrão de secreção. Com 
1

TSH

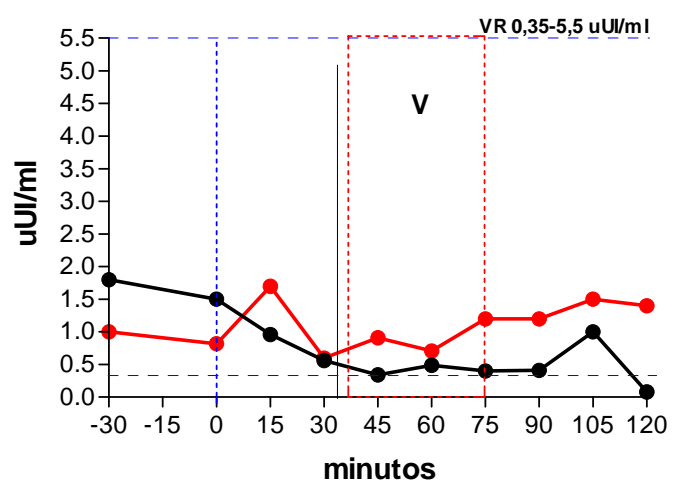

3

TSH

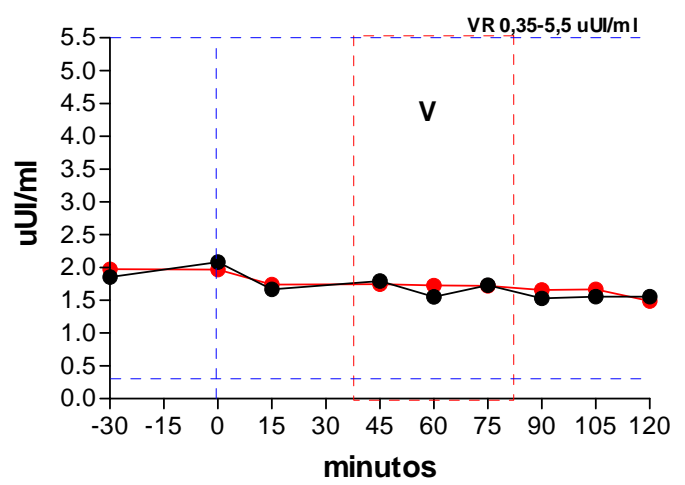

5

TSH

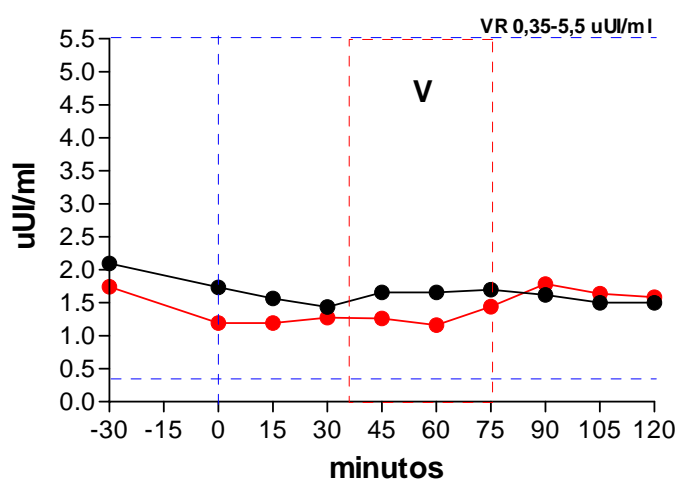

2

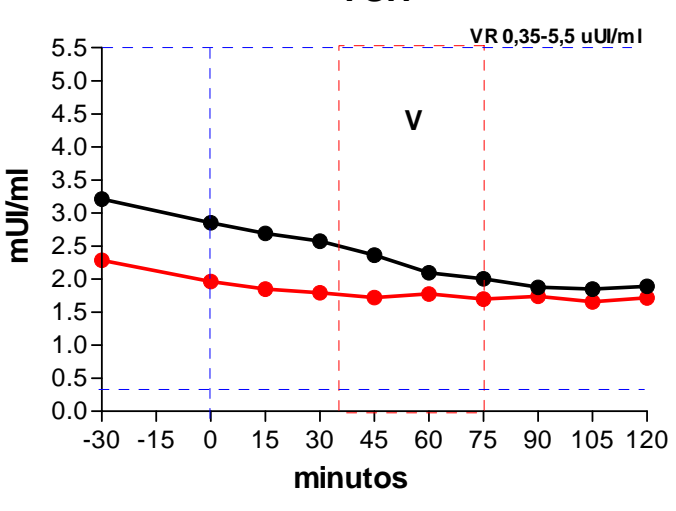

4

TSH

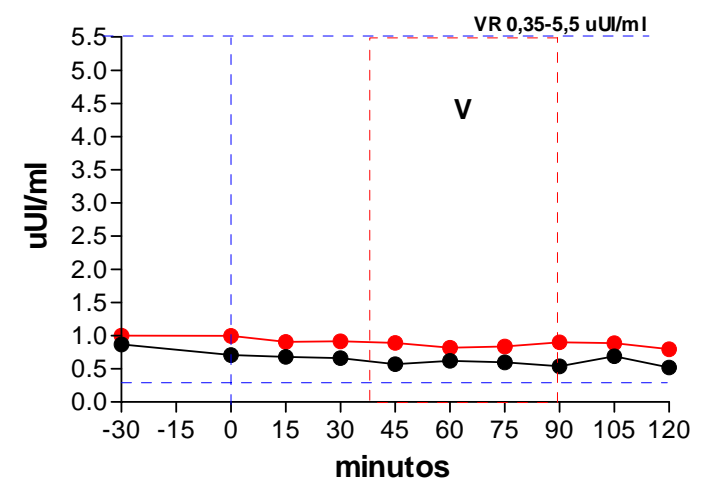

6

TSH

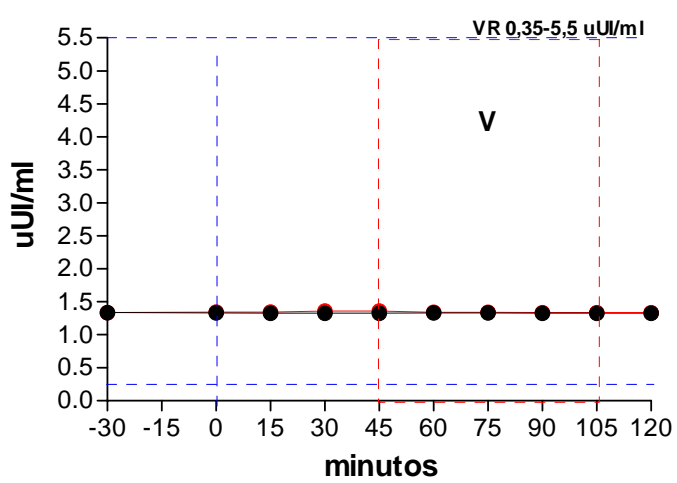

Figura 27 - curvas de tempo e resposta das variações de TSH nos 6 sujeitos submetidos à recuperação de memórias traumáticas, .

$\bullet-\bullet$ - condição controle (CC).

$\bullet$-• - condição de recuperação (CR).

V - vivência.

VR - valores de referência para o ensaio 
1

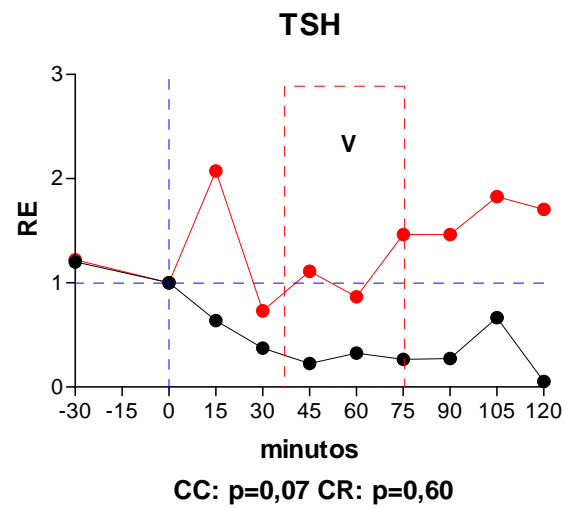

3

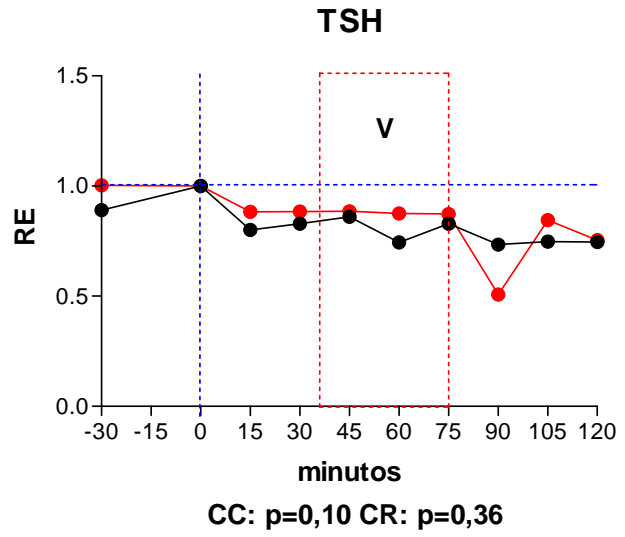

5

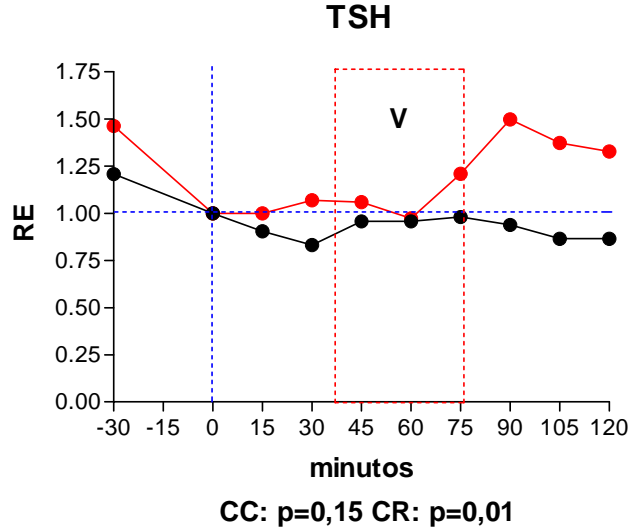

2

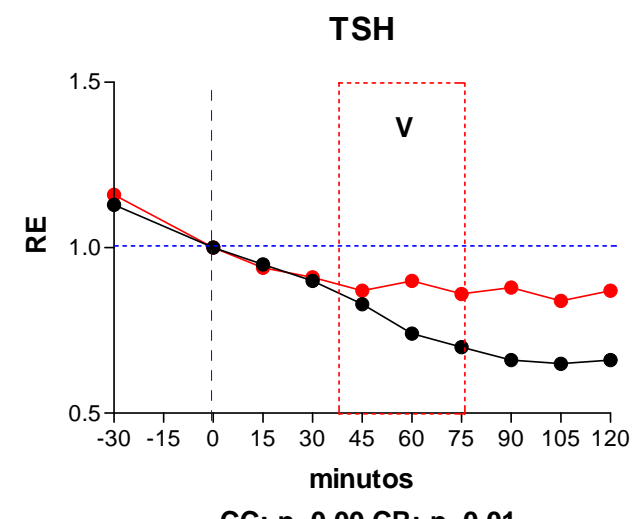

4

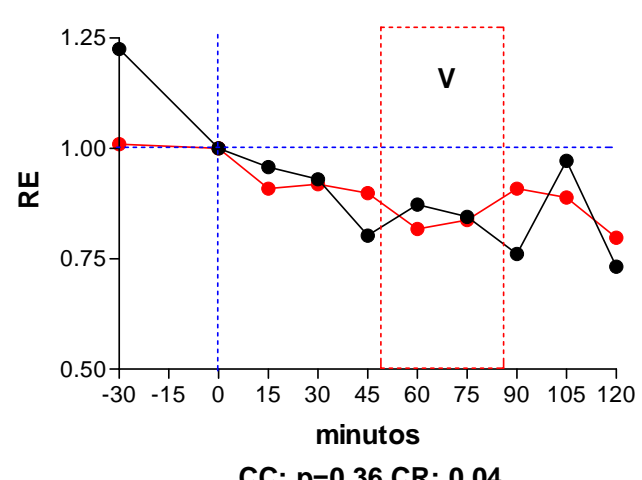

6

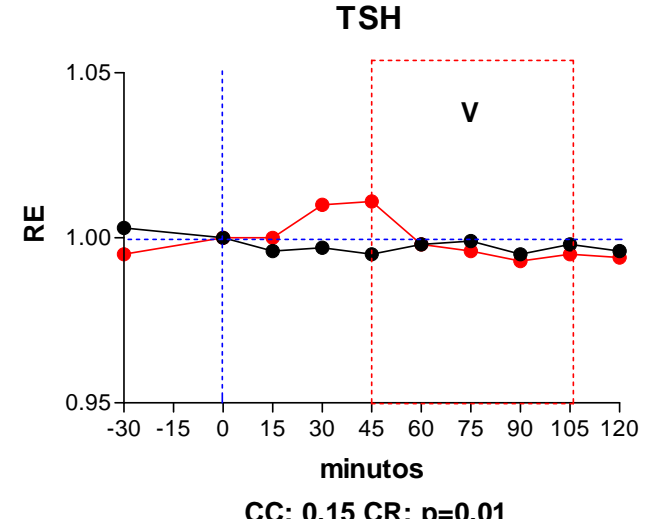

Figura 28- curvas rescalonadas de tempo e resposta de TSH nos 6 sujeitos submetidos à recuperação de memórias traumáticas.

$\bullet-\bullet$ - condição controle (CC).

$\bullet$-• - condição de recuperação (CR).

V - vivência. 
efeito, é exatamente nestes sujeitos (além do sujeito 6) que não se observa resposta do TSH ao estresse. A bem da verdade, não se pode estabelecer comparações claras entre a ausência de resposta e os diagnósticos revelados pelos testes aplicados: sujeitos 2 e 6 com FSO (SCIDDSM-IV 300.23) e sujeitos 3 e 4, sem diagnóstico.

Vale lembrar que, no TEPT ocorre aumento de T3 live, T4 total e TBG, sem alterações do T4 livre e do TSH. Como o T3 livre tem grande potência biológica, a ausência de resposta do TSH ao estresse talvez tenha se devido à retroalimentação negativa exercida pelo T3 livre sobre a adenohipófise (WANG; MASON, 1999). Com efeito, mulheres com TEPT devido a abuso sexual na infância apresentam elevação significativa tanto do T3 total quanto das proporções entre T4 livre e T3 total, entre T3 livre e T3 total, assim como redução dos níveis de TSH (FRIEDMAN et al., 2005). Talvez, especulativamente, fenômenos semelhantes tenham ocorrido nos não respondedores.

5.2.5. GH (Quadro VII, Figuras 29 e 30, Tabelas VII e VIII).

Os dados obtidos indicam resposta do $\mathrm{GH}$ ao processo de Rec-Mem nos sujeitos 1, 2,3 e 5 e são sugestivos de resposta no sujeito 6 . O sujeitos 4 não apresentou resposta.

Conforme discutido anteriormente, a secreção do GH tem, como principais fatores reguladores, o hormônio de liberação do GH (GHRH), a somatostatina (SRIF), o peptídeo liberador do GH (GHrerin) e o IGF-I (insulin-like growth factor), havendo a participação de receptores $\beta 2$-adrenérgicos e $\alpha 2$-adrenérgicos, via somatostatina e GHRH. Do balanço líquido entre impulsos estimuladores e inibidores, sua secreção se expressa por meio de um ritmo circadiano, assim como por picos espontâneos de liberação durante o dia (pouco freqüentes, ocorrendo cerca de 3 a 4 horas após as refeições, podendo ser intensos) e pelos que ocorrem durante o sono (uniformes e constantes) havendo diversidade de sua secreção segundo o sexo (CATALDI et al., 1994; GIUSTINA; VELDHUIS,1998; WINER et. al., 1990). Impulsos provenientes da amigdala, tanto estimuladores quanto inibidores, indicam a existência de 
1

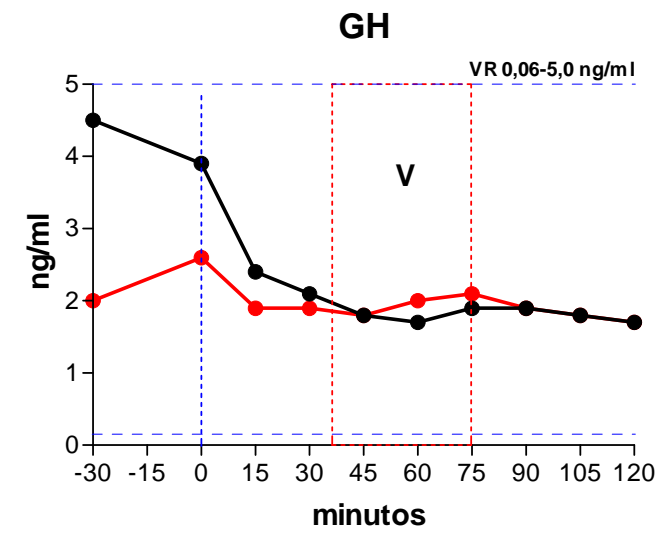

3

GH

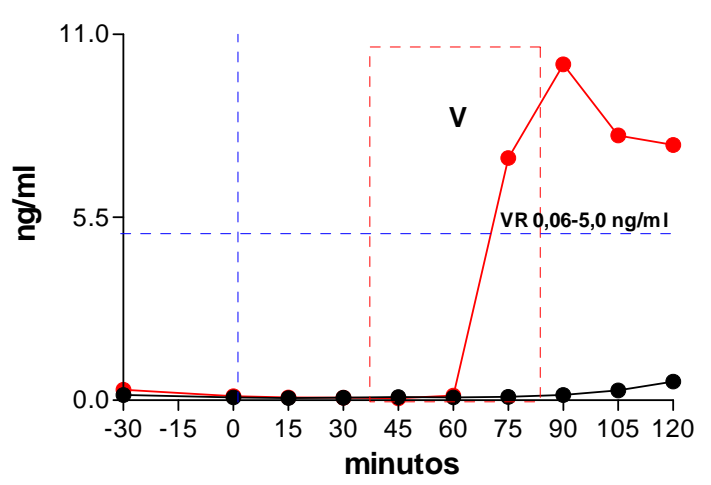

5

GH

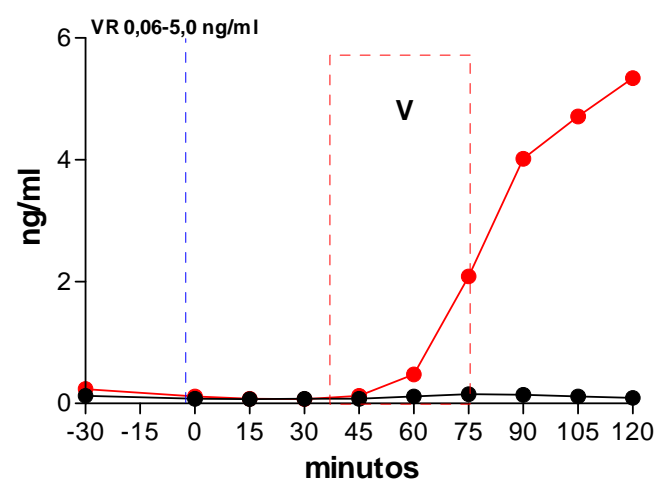

2

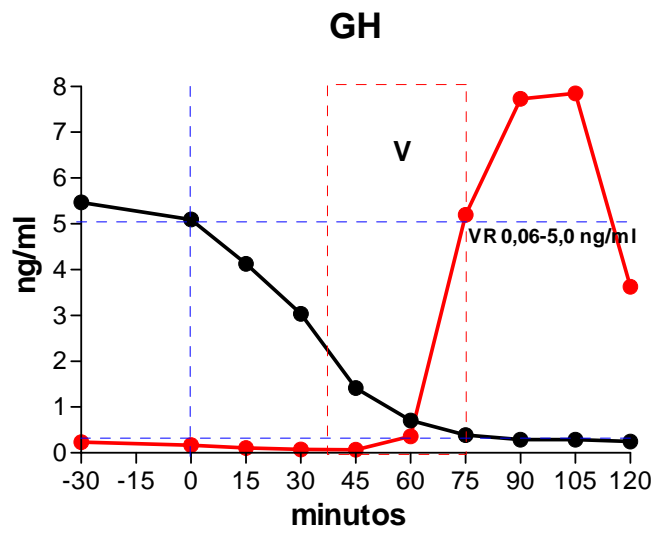

4

GH

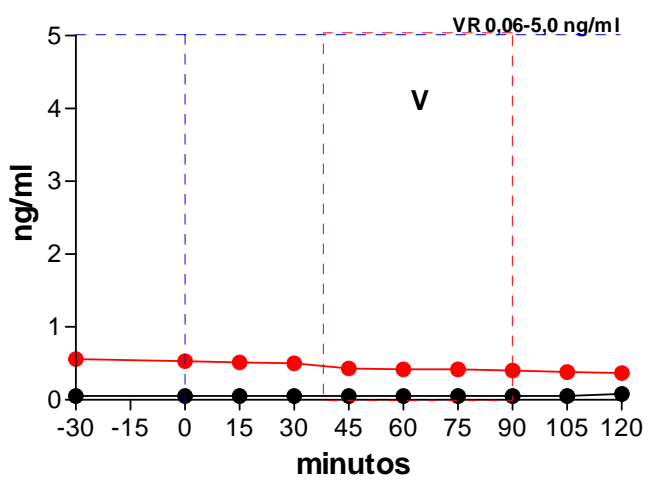

6

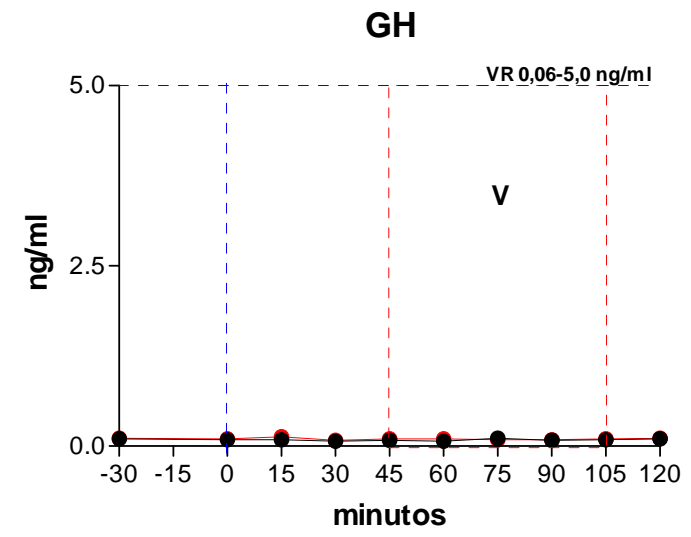

Figura 29 - curvas de tempo e resposta das variações de GH nos 6 sujeitos submetidos à recuperação de memórias traumáticas, .

$\bullet$-• - condição controle (CC).

$\bullet$-• - condição de recuperação (CR).

V - vivência.

VR - valores de referência para o ensaio 
1

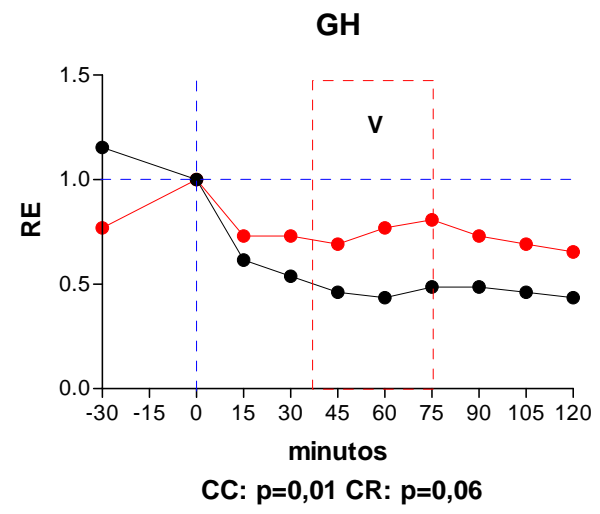

3

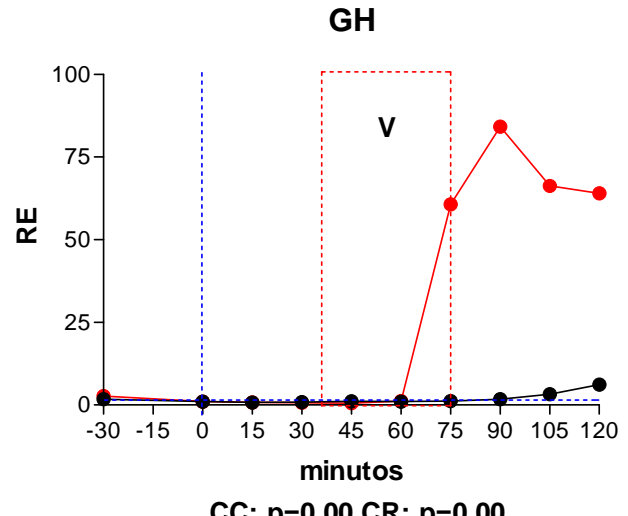

5

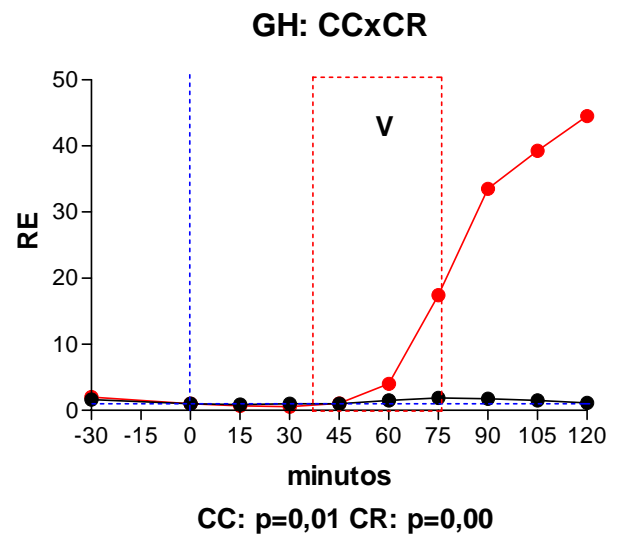

2

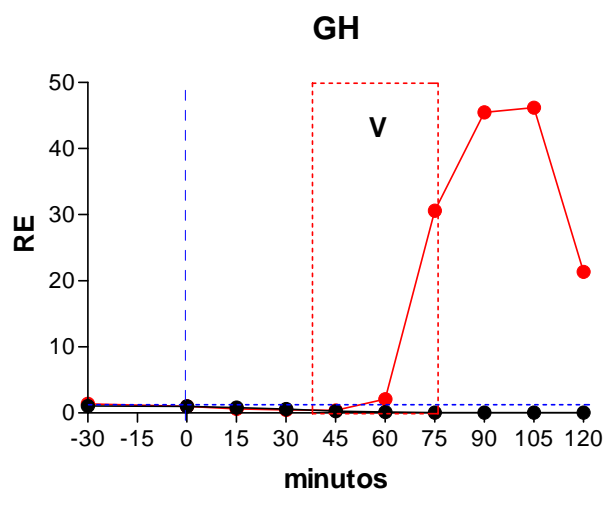

CC: $p=0,00$ CR: $p=0,01$

4

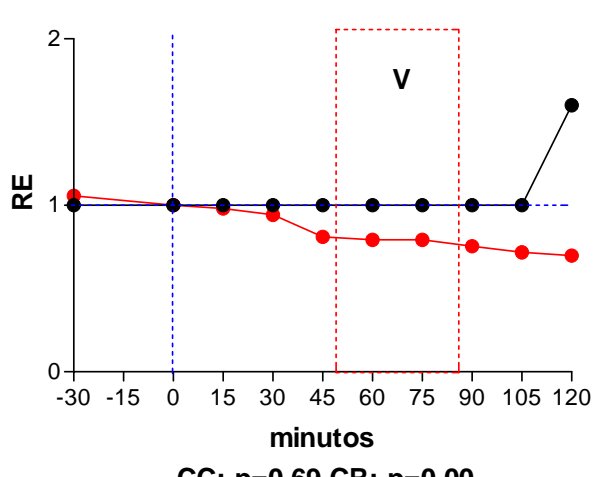

6

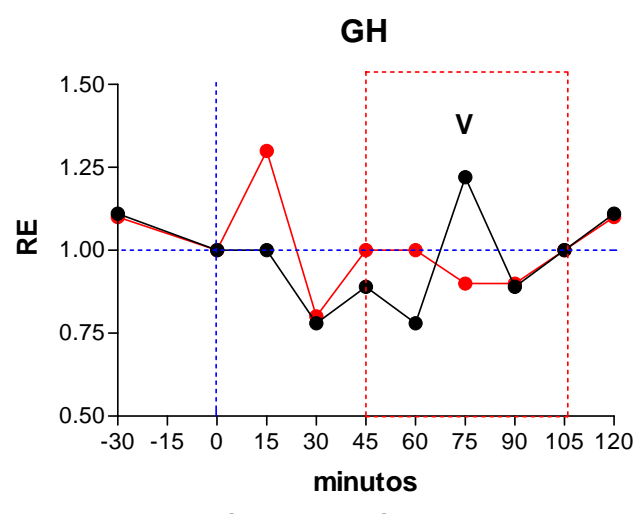

CR: $p=0,01$ CR: $p=0,00$

Figura 30- curvas rescalonadas de tempo e resposta de TSH nos 6 sujeitos submetidos à recuperação de memórias traumáticas.

$\bullet-\bullet$ - condição controle (CC).

$\bullet-\bullet$ - condição de recuperação (CR).

V - vivência. 
bases emocionais das respostas do GH ao estresse. Muito importante, nesta resposta, é a relação existente entre a secreção de adrenalina e a do GH, via estimulação de receptores $\alpha 2$ adrenérgicos. A resposta do $\mathrm{GH}$ ao estresse parece depender, também, da ação central de adrenomedulina que aparentemente atua por meio da estimulação do CRH (TAYLOR; SAMSON, 2004). Outros hormônios podem influenciar a secreção de GH, tais como estrógenos, progesterona, testosterona, TSH, hormônios tireoidianos, TRH e glicocorticóides.

Os sujeitos 2,3 e 5 apresentaram secreção de GH de um modo muito intenso, com início coincidente com a manifestação emocional da vivência. Se compararmos as curvas de secreção de adrenalina e GH nestes sujeitos, vemos que existe uma relação temporal entre elas, com o início da secreção de GH se dando sempre com um atraso de 15 a 30 minutos. Este fato, tal como já discutido no item 5.1, sugere relação entre ambos os hormônios, em concordância com a literatura (CATALDI et al., 1994; GIUSTINA; VELDHUIS,1998).

Os dados obtidos para os sujeitos 4 e 6 são apenas sugestivos de resposta de adrenalina sem resposta conclusiva para o GH (apenas sugestivo no sujeito 6).

Embora o reduzido número de casos, cada um deles representa uma resposta póstraumática particular. Nossos resultados permitem sugerir que a resposta hormonal à recuperação de memórias traumáticas é individual. Aparentemente, a resposta deve-se às características psicológicas de cada indivíduo, às suas vivências prévias, ao estado emocional existente durante a experiência traumática, às suas vivências pós-traumáticas, sendo todas elas, talvez, as principais variáveis, entre tantas outras, que modificam as reações do indivíduo ao trauma psicológico. O nome da situação: "transtornos do estresse pós-traumático" indica muito bem o que pode ser esperado. É evidente que cada situação traumática induz uma resposta de estresse individual que depende da situação na qual esta aconteceu, do acervo psicológico prévio e das experiências posteriores. 
Por todos os motivos expostos pensamos que seria utópico encontrar uma resposta hormonal patognomônica à recuperação de memórias traumáticas. 
Você deseja isso uma vez mais, e inumeráveis vezes mais?

(Nietzsche)

6. CONCLUSÕES 


\section{Conclusões}

6.1. A recuperação de memórias traumáticas, obtida pela metodologia utilizada, representa uma forma de estresse psicológico que é capaz de produzir respostas autonômicas e neuroendócrinas.

6.2. Neste sentido, a revivenciação de tais memórias, em seu caráter estressor, equivale a um trauma de origem externa ao sujeito.

6.3. Tais respostas são de caráter individual, afetando diferentes hormônios de maneira diversa, sem apresentar padrão de resposta comum entre os sujeitos.

6.4. Isto indica a existência de sistemas de controle autonômico e neuroendócrino que operam de maneira diferenciada na resposta a este tipo de estresse.

6.5. Este fato expressa, no complexo sistema neurofisiológico de resposta ao estresse, a influência das características individuais dos sujeitos, da sua percepção subjetiva dos traumas e/ou de níveis diferentes de estimulação neurofisiológica. 
Voltar-se para a luz significa voltar-se para o que permite ver e entender.

(Gustavo Pinto)

7. REFERÊNCIAS 
ABE, K. Modulation of hippocampal long-term potentiation by the amygdala: a synaptic mechanism linking emotion and memory. Jpn J. Pharmacol,. Vol. 86, n. 1, p.18-22, 2001.

ALLIOT, J.; GIRDY, N. Acquisition of matching-to-sample task in young and middle-aged male and female rats. Neuroreport, n. 2, p. 101-104, 1991.

ALLIOT, J.; NAUTON, P.; BRUHAT, M.A. Administration of LHRH analog can improve working memory in aged female rats. Psychoneuroendocrinology, vol 18, n. 8, p. 543-550, 1993.

ANDERSON, G.W. Thyroid hormones and the brain. Frot Neuroendocrinol, vol . 22, n. 1, p. $1-17,2001$.

ARMARIO, A.; CASTELlANOS, J. M.; BALAXH, J. Effect of acute and chronic psychogenic stress on corticoadrenal and pituitary-thyroid hormones in male rats. Horm Res, vol. 20 , n. 4 , p. 241-245, 1984.

ARMARIO, A.; GARCIA-MARQUEZ, C.; JOLIN, T. The effect of chronic intermittent stress on basal and acute stress levels of TSH and GH, and their response to hypothalamic regulatory factors in the rat. Psychoneuroendocrinology, n. 5, p.399-406, 1987.

BAUER, M.; WHYBROW, P. C. Thyroid hormone, neural tissue and mood modulation. World J Biol Psychiatry, vol. 2, n. 2, p. 56-69, 2001.

BAUM, H. B.; KATZNELSON, L.; SHERMAN, J.C.; BILLER, B.M.; HAYDEN, D.L.; SCHOENFELD, D.A.; CANNISTRARO, K.E.; KLIBANSKI, A.. Effects of physiological growth hormone $(\mathrm{GH})$ therapy on cognition and quality of life in patients with adult-onset $\mathrm{GH}$ deficiency. J Clin Endocrinol Metab, vol 89, n. 9, p. 3184-3189, 1998.

BECKMAN, M. American Association for the Advancement of Science Meetings - False memories, true pain. Science, vol 299, n. 5611, p. 1305, 2004.

BIONDI, M.; PICARDI, A. Psychological stress and neuroendocrine function in humans: the last two decades of research. Psychother Psychossom,. vol. 63, n. 3, p. 114-150, 1999.

BOLE-FEYSOT, C.; GOFFIN, V.; EDERLY, M.; KELLY, P.A. Prolactin (PRL) and its receptor: actions, signal transduction pathways and phenotypes observed in PRL receptor knockout mice. Endocr Rev, 19: 225-268, 1998.

BRESLAU, N., DAVIS, G.C.; ANDRESKI, P.; PETERSON, E. Traumatic events and posttraumatic stress disorder in an urban population of young adults. Archives of General Psychiatry 48, 216-222, 1991.

BUCHANAN, T. W.; LOVALLO, W. R. Enhanced memory for emotional material following stress-level cortisol treatment in humans. Psychoneuroendocrinology, n. 26, p.307-317, 2001.

BURMEISTER, L. A. GANGULI, M.; DODGE, H.H.; TOCZEK, T.; DEKOSKY, S.T.; NEBES, R.D. Hypothyroidism and cognition: preliminary evidence for a specific defect in memory. Thyroid, vol. 12, p. 1177-1185, 2001. 
CAHILL, L.; ALKIRE, M. T. Epinephrine enhancemente of human memory consolidation: interaction with arousal at encoding. Neurobiology of Learning and Memory, n. 79, 79:194198, 2003.

CATAldi, M.; MAGNAN, E.; GUILlaumE, V.; DUTOUR, A.; SAUZE, N.; MAZZOCCHI, L.; CONTE-DEVOLX, B.; OLIVER, C. Acute stress stimulates secretion of GHRH and somatostatin into hypophysial portal blood of conscious sheep. Neurosci Lett., vol. 178, p.103-106, 1994.

CAVINI-FERREIRA, R.; SINGAL, W. Correlação entre doenças psiquiátricas e doenças endócrinas: uma experiência de oito anos no atendimento endocrinometabólico de pacientes da área da saúde mental. Rev Bras Med, n. 51, p. 730-736, 1994.

CAVINI-FERREIRA, R. Psiconeuroendocrinologia da depressão: análise de 72 pacientes. Rev Bras Med Psicossomática, vol. 3, n. 3, p. 39-44, 1999.

CAVINI-FERREIRA, R.; PERES, J.F.P.; PERES, M.J.M.P.; NASELLO, A.G. Autonomic and neuroendocrine responses to imaginary traumatic situation. XII Congresso Interno NAP, NeC, USP, 2002.

CAVINI-FERREIRA, R.C.; PERES, J.F.P.; NASELLO, A.G. Imaginary traumatic situation and real traumatic memory retrieval: comparative automomic and neuroendocrine responses a preliminary study. XIII Congresso Interno NAP, NeC, USP, 2003.

CHAFIN, S.; ROY, M.; GERIN, W.; CHRISTENFELD, N. Music can facilitate blood pressure recovery from stress. Br J Health Psychol., Vol. 9, Pt 3, p. 393-403, 2004.

CHAN, V.; WANG, C.; YEOUNG, R. T. Pituitary-thyroid responses to surgical stress. Acta Endocriol (Copenh), vol 88, n. 3, p. 490-498, 1978.

CHEN, M. F.; CHIU, T. H.; LEE, E. H. Y. Noradrenergic mediation of the memoryenhancing effect of corticotrophin-releasing factor in the locus coeruleus of rats. Psychoneuroendocrinology, vol 17, n. 2/3, p. 113-124, 1992.

CONTE-DEVOIX, B.; GUILLAUME, V.; GRINO, M.; BOUDOURESQUE, F.; MAGNAN, R.; CATALDI, M.; OLIVER, C. Stress. Neuroendocrine aspects. Enchepale, vol.19 Spec. n. 1, p.143-146, 1993.

DE KLOET, E. R.; VREUGDENHILL, M.; OITZL, M.S., JOELS, M. Brain corticosteroid receptor balance in health and disease. Endocrine Reviews, n. 19, p. 269-301, 1998.

DEIJEN, J. B.; DE BOER, H., VAN DER VEEN, E. A. Cognitive changes during growth hormone replacement in adult men. Psychoneuroendocrinology, vol. 23, n. 1, p. 45-55, 1998.

DELITALA, G.; TOMASI, P.; VIRDIS, R. Prolactin, growth hormone and thyrotropinthyroid hormone secretion during stress states in man. Bailleres Clin Endocrinol Metab, vol. 1, n. 2, p.391-414, 1987.

DELMONTE, M.M. Retrieved memories of childhood sexual abuse. British Journal of Medical Psychology, vol 73, p. 1-13, 2000. 
DRAGO, F.; BOHUS, B.; GISPEN, W.H.; VANREE, J. M.; SCAPAGNINI, U.; DE WIED, D. Behavioral changes in short term and long term hyperprolactinemic rats. Dev Neurosc, n. 16, p. 417-427, 1983.

DSM-IV - Manual Diagnóstico e Estatístico de Transtornos Mentais, trad. Ayse Batista; 4a . ed., Porto Alegre: Artes Médicas, 1995.

DEVITO, W.J. - Distribution of immunoreactive prolactin in the male and female rat brain: effects of hypophysectomy and intraventricular administration of colchicine. Neuroendocrinology, vol. 47, p. 284-289, 1988.

EMANUELE, N. V.; METCALFE, L.; WALLOCK, L.; TENTLER, J.; HAGEN, T.C.; BEER, C.T.; MARTINSON, D.; GOUT, P. W.; KIRSTEINS, L.; LAWRENCE, A. M.. Extrahypothalamic brain prolactin: characterization and evidence for independence from pituitary prolactin. Brain Res, vol. 421, p. 255-262, 1987.

FISHER, L.A. Cortisotrophin-releasing factor: endocrine and autonomic integration of responses to stress. TIPS, n. 10, p. 189-193, 1989.

FREEMARK, M; DRISCOLL, P.; ANDREWS, J.; KELLY, P.A.; ROYSTER, M. Ontogenesis of prolactin receptor gene expression in the rat olfactory system: potential roles for lactogenic hormones in olfactory development. Endocrinology, n. 137, .34-942, 1996.

FREEMARK, M.; NAGANO, M.; EDERY, M.; KELLY, P. A. Prolactin receptor gene expression in the fetal rat. J Endocrinol, vol. 144, p. 285-292, 1995.

FRIEDMAN, M.J.; WANG, S.; JALOWIEC, J.E.; MCHUGO, G.J.; MCDONAGH-COYLE A. Thyroid hormone alterations among women with posttraumatic stress disorder due to childhood sexual abuse. Biol Psychiatr,. n. 57vol. 10, p, 1186-1192, 2005.

FOOTE, S.L.; BLOOM, F.E.; ASTON-JONES, G. Nucleus locus ceruleus: new evidence of anatomical and physiological specifity. Physiol Rev, n. 63, p. 844-914,1983.

FUKUI, H.; YAMASHITA, M. The effects of music and visual stress on testosterone and cortisol in men and women. Neuro Endocrinol Lett. vol. 24, n. (3-4), p. 173-180, 2003.

FUXE, K.; HÖKFELT, T.; ENEROTH, P.; GUSTAFSSON, J. A.; SKETT, P. Prolactin-like immunoreactivity: localization in nerve terminals of rat hypothalamus. Science, n. 196, p. 899-900, 1977.

GANN, D.C. Parameters of the stimulus initiating the adrenocortical response to hemorrhage. Am NY Acad Sci, n. 156, p. 740-755, 1969.

GARCIA-SEGURA, I. M.; CHOWEN, J. A.; NAFTOLIN, F. Endocrine glia: roles of glial cells in brains actions of steroid and thyroid hormones and in the regulation of hormone secretion. Frontiers in Neuroendocrinology, n. 17, p. 180-211, 1996. 
GILBERTSON, M. W.; SHENTON, M.E.; CISZEWSKI, A.; KASAI, K.; LASKO, N. B.; ORR, S. P.; PITMAN, R. K. Smaller hippocampal volume predicts pathologic vulnerability to psychological trauma. Nat Neurosci., vol. 5, n. 11, p. 1242-1247, 2002.

GIBBS, M.E.; SUMMERES, R.J Role of adrenoceptor subtypes in memory consolidation. Progress in Neurobiology, n. 67, p.345-391, 2002.

GIUSTINA, A.; VELDHUIS, J. D. Pathophysiology of the neuroregulation of growth hormone secretion in experimental animals and the human. Endocrine Reviews, vol. 19, n. 6, p. 717-797, 1998.

GOFFIN, V.; BINART, N.; TOURAINE, P.; KELLY, P. A. Prolactin: the new biology of an old hormone. Annu. Ver. Physiol, n. 64, p. 47-67, 2002.

GONSALVES, B.; PALLER, K.A. Mistaken memories: remembering events that never happened. Neuroscientist, n. 8, p. 391-395, 2002.

GOULD, E.; WOOLLEY, C, S.; MCEWEN, B. S. The hippocampal formation: morphological changes induced by thyroid, gonadal and adrenal hormones. Psychoneuroendocrinology, vol. 16, n. 1-3, p. 67-84. 1991

GOULD, E.; WOOLLEY, C. S. et al., Gonadal steroids regulate dendritic spine density in hippocampal pyramidal cells in adulthood J Neurosci., N. 4, p.1286-1291, 1990-a.

GOULD, E.; ALLAN, M. D.; McEWEN, B. S. Dendritic spine density of adult hippocampal pyramidal cells is sensitive to thyroid hormone. Brain Res., vol.525, n. 2, p. 327-9, 1990-b.

GOULD, E.; WOOLLEY, C. S.; McEWEN, B. S. Short-term glucocorticoid manipulations affect neuronal morphology and survival in the adult dentate gyrus. Neuroscience, vol. $37, \mathrm{n}$. 2, p. 367-75, 1990-c.

GRAEFF, G. Bases biológicas do transtorno do estresse pós-traumático. Rev Bras Psiquiatr, vol. 25, Supl. I, p. 21-24, 2003.

HALL, J.; THOMAS, K.L.; EVERITT, B.J. Fear memory retrieval induces CREB fosforilation and Fos expression within the amygdala. Eur J Neurosci., vol. 13, n. 7, p. 1453$1458,2001$.

HAMID, S. A.; BAXTER, G. F. Adrenomedullin: regulator of systemic and cardiac homeostasis in acute myocardial infarction. Pharmacol Ther, vol. 105, n. 2 , p. 95-112, 2005.

HANSON, J.D.; LARSON, M.E.; SNOWDOWN, C.T. The effects of control over high intensity noise on plasma cortisol levels in rhesus monkeys. Behav. Biol., n. 16, p. 333-340, 1976.

HARLAN, R.E.; SHIVERS, B.D.; FOX, S.R.; KAPLOVE, K.A. SCHACHTER, B.S.; PFAFF, S.W. Distribution and partial characterization of immunoreactive prolactin in the rat brain. Neuroendocrinology, vol. 49, p. 7-22, 1989. 
HARRIS, G.W. Neural control of the pituitary gland. Physiol.Rev, n. 28, p. 139, 1948.

HENLEY, W. N.; KOEHNLE, T. J. Thyroid hormones and the treatment of depression: an examination of basic hormonal actions in the mature mammalian brain. Synapse, vol. 27, n. 1, p. 36-44, 1997.

HENNESSY, J. W.; LEVINE, S. Stress, arousal and the pituitary adrenal system: a psychoendocrine model. Prog Psychobiol Pshysiol Psychol, 8, 1979.

HODDES, E.S. Effect of growth hormone on memory in mice. Sleep, vol 1, n. 3, p. 287-297, 1979.

HOGERVORST, E.; BOSHUISEN, M.; RIEDEL, W.; WILLEKEN, C.; JOLLES, J. 1998 Curt P. Richter Award. The effect of hormone replacement therapy on cognitive function in elderly women. Psychoneuroendocrinology, vol. 24, n. 1, p. 43-68, 1999.

HOGERVORST, E.; YAFFE, K.; RICHARDS, M.; HUPPERT, F. Hormone replacement therapy for cognitive function in postmenopausal women. Cochrane Database Syst Rev n. 3, CD003122, 2002.

HOGERVORST, E.; DE JAGER, C.; BUDGE, M.; SMITH, A.D. Serum levels of estradiol and testosterone and performance in different cognitive domains in healthy elderly men and women. Psychoneuroendocrinology, vol, n. 3, p. 405-421, 2004.

HOLGER, U.; ERIKSEN. H. R. The cognitive activation theory of stress. Psychoneuroendocrinology, vol. 29, n. 5, p. 567-592, 2004.

HORNE, J.A; OSTBERG, O. A self-assesssment questionnaire to determine morningnesseveningness in human circadian rythms. International Journal of Chronobiology, vol. 4, p. 97-110, 1976.

HUCKLEBRIDGE, F. The impact of psychosocial stress on immune function in the athletic population. Exerc Immunol, Rev n. 7, p. 5-17, 2001.

IZQUIERDO, I. Mecanismo das memórias. In: Complexidade e Caos. Organização H. Moisés, Nussenveig, Rio de Janeiro: Ed. UFRJ/COPEA. p. 185-190, 1999.

IZQUIERDO,I. A modulação das memórias: influencia do nível de alerta, do nível de ansiedade e do estado de ânimo. Memória, p. 63-71, Porto Alegre: Artmed, 2002

IZQUIERDO, I. A arte de esquecer. Cérebro, Memoria e Esquecimento, Rio de Janeiro: Vieira@Lent, 2004.

IZQUIERDO, J.; MEDINA, J. H. Role of the amygdala, hippocampus and entorhinal cortex in memory consodilation and expression. Braz J Med Biol Res, vol 26, n. 6, p. 573-579, 1993.

JOHANSSON, G. et al., Examination stress affects plasma levels of TSH and thyroid hormones differently in females and males. Psychosom Med., vol. 49, n. 4, p. 390-396, 1987. 
KANDELL, E.R. Learning and memory. In: Principles in neuroscience, NY: McGraw-Hill, p. $1227,2000$.

KANDELL, E.R. Learning and memory. In: Principles in neuroscience, NY: McGraw-Hill, p. $1237-1238,2000$.

KHALFA, S. Effects of relaxing music on salivary cortisol level after psychological stress. Ann N Y Acad Sci, n. 999, p. 374-376, 2003.

KÖHRLE, J. Thyroid hormones metabolism and action in the brain and pituitary. Acta Medica Austrica, VO. 27, P. 1-10, 2000.

LANGER, P.; VIGAS, M.; KVETNANSKY, R.; FOLDES, O.; CULMAN, J. Immediate increase of thyroid hormone releasing firing acute stress in rats: effect of biogenic amines rather than that of TSH? Acta Endocrinol (Copenh), vol. 104, n. 4, p. 443-439, 1983.

LEICHTMAN, M.D.; WANG, Q.; DAVIERS, K.I. Sharing memories and telling stories: American and Chinese mothers and their 3-years-olds. Memory n. 8, p. 159, 177, 2000.

LOFTUS, E.F. Memory distortion and false memory creation. Bulletin of the American Academy of Psychiatry and Law. n. 24, p. 281-295, 1996.

LOFTUS, E.F.; POLAGE, D.C. Repressed memories. When are they real? How are they false? Psichiatric Clinics of North America, vol. 22, p. 61-70, 1999.

MAREN, S. Long term potentiation in the amygdala: a mechanism for emotional learning and memory. Trends Neurosci., vol. 23, n. 8, p. 345-346, 2000.

MASON, J.W. A historical view of the stress field. J.Hum.Stress, n. I, p. 6-12, 1975.

McEWEN, B.S. Stress and hippocampal plasticity. Annu Rev Neurosci,. vol 22, p. 105 - 122, 1999.

McGAUGH, J.L.; McINTYRE, C.K.; POWER, A.E. Amygdala modulation of memory consolidation: interaction with other brain systems. Neurobiology of Learning and Memory. vol 78, p. 539-552, 2002.

McGAUGH, J.L. Memory consolidation and the amygdala: a systems perspective. Trends Neurosci, vol 25, n. 9, p. 456-461, 2002.

McGAUGH, J.L.; GOLD, P.E. Hormonal Modulation of Memory. In: Psychoendocrinology, Ed. Brush \& Levine, Academic Press Inc, p. 305-340, 1989.

MCINTYRE, C.K.; POWER, A.E.; ROOZENDAAL, B.; MCGAUGH, J.L. Role of basolateral amygdala in memory consolidation. Ann N Y Acad Sci., n. 985, p. 273-293, 2003.

MENNEMEIER, M.; GARNER, R. D.; HELLMAN, K. M. Memory, mood and measurement in hypothyroidism. J Clin Exp Neuropphysiol, vol 53, n. 4, p. 234-239, 1998. 
MIGNEAULT, B.; GIRARD, F.; ALBERT, C.; CHOUNIARD, P.; BEAUDREAULT, D.; PROVENCHER, D.; TODOROV, A.; RUEL, M.; GIRARD, D. C. The effect of music on the neurohormonal stress response to surgery under general anesthesia. Anesth Analg., vol 98, n. 2, p.:527-532, 2004.

MILUK-KOLASA, B.; OBMINSKI, Z.; STUPNICKI, R.; GOLEC L. Effects of music treatment on salivary cortisol in patients exposed to pre-surgical stress. Exp Clin Endocrinol., vol. 102, n. 2, p.118-120, 1994.

MORA, S.; NASELLO, A.G.; MANDELLI-LOPES, M.; DIAZ-VELIZ, G. LHRH and rat avoidance behavior: influence of castration and testosterone. Physiol Behav vol. 30, n. 1, p. 19-22, 1983.

MORA, S.; NASELLO, A.G. TRH on rats conditioned avoidance behavior: interaction with brain catecholamines. Pharmacol Biochem Behav vol. 13, n. 1, p. 137-139, 1980.

MONZANI, F.; PRUNETI, C.A.; DE NEGRI, F.; SIMONCINI, M.; NERI, S.; DI BELLO, V.; BARACCHINI MURATORIO, G.; BASCHIERI, L. Preclinical hypothyroidism: early involvement of memory function, behavioral responsiveness and myocardial contractility. Minerva Endocrinol, vol. 16, n. 3, p. 113-118, 1991.

NASELLO, A.G.; BYDLOWSKI, C.R.; FELICIO, L.F. The effect of LHRH on rato conditioned avoidance behavior: interaction with brain catecholamines. Pharmacol Biochem Beha. vol 37, n. 4, p. 639-642, 1990.

NAGANO, M.; KELLY, P. A. Tissue distribution and regulation of rat prolactin receptor gene expression. Quantitative analysis by polymerase chain reaction. J Biol Chem, n. 269, p. 13337-13345, 1994.

NUCKSOLLS, K.B.; CASSEL, J.; KAPLAN, B.H. Psychosocial assets, life crisis and the prognosis of pregnancy. Am. J. Epidemiol, n. 95, p. 431-441, 1972.

PELLETIER, C. L. The effect of music on decreasing arousal due to stress: a meta-analysis. $J$ Music Ther, vol. 41, n. 3, p.192-214, 2004.

PERES, J.F.P.; MERCANTE, J.P.P.; PRIETO-PERES, M.J.; NASELLO, A.G. Psychological dynamics affecting traumatic memories: implications in psychotherapy. Psychology and Psychotherapy: Theory, Research and Practice, 2005.

PETRUSZ, P.; MERCHENTHALER, I. The corticotrophin-releasing factor system - in: Neuroendocrinology, Nemeroff, C.B., ed., Boca Ratón: CRC Press, p.129-183, 1992.

PHILLIPS, S.M.; SHERWIN, B. B. Effects of estrogen on memory function in surgically menopausal women. Psychoneuroendocrinology, vol.17, n 5, p. 485-495, 1992-a.

PHILLIPS, S.M.; SHERWIN, B. B. Variations in memory function and sex steroid hormones across the menstrual cycle. Psychoneuroendocrinology, vol. 17, n. 5, p. 497-506,1992-b. 
PRUESSNER, J. C.; HELLHAMMER, D. H.; KIRSCHBAUM, C. Low self-steem, induced failure and the adrenocortical stress response. Personality and Individual Differences., n. 27, p. 477-489, 1999.

RESNIK, H. S.; YEAHUDA, R.; PITMAN, R. K.; FOY, D. W. Effect of previous trauma on acute plasma cortisol levels following rape. Am j Psychiatry, n. 152, p. 1675-1677, 1995.

RIDER, M.S.; FLOYD, J.W.; KIRKPATRICK, J. The effect of music, therapy, and relaxation on adrenal corticosteroids and the re-entrainment of circadian rhythms. J Music Ther, vol. 22, n. 1, p. $46-58,1985$.

RIGTER, H.; VAN RIEZEN, H.; DE WIED, D. The effect of ACTH and vasopressin analogs on $\mathrm{CO}_{2}$ induced retrograde amnesia in rats. Psysiol Behav, n. 13, p. 381-338, 1974.

RIGTER, H. Vasopressin and memory. The influence of prior experience with the training situation. Behav Neural Biol, n. 34, p 337-351, 1982.

RODRIGUEZ, T.; ALBUQUERQUE-ARAUJO, W.I.; REIS, L.C.; ANTUNESRODRIGUES, J.; RAMALHO, M. J. Hypothyroidism attenuates stress-induced prolactin and corticosterone release in septic rats. Exp. Physiol, vol. 88, n. 6, p. 755-760, 2003.

ROOZENDAAL, B. Stress and memory: opposing effects of glucocorticoids on memory consolidation and memory retrieval. Neurobiol Learn Mem, vol. 78, n. 3, p. 578-595, 2002.

ROSE, R.M.; JENKINS, C.D.; HURST, M.; LIVINGSTON, L.; HALL, R.P. Endocrine activity in air traffic controllers at work. I. Characterization of cortisol and growth hormone levels during the day. Psychoneuroendocrinology, n. 7, p. 101-111, 1982.

SAPOLSKY, R. M. Stress, the Aging Brain and the Mechanism of Neuron Death. Cambridge, MA: MIT Press, 1992.

SAPOLSKY, R. M. Chickens, eggs and hippocampal atrophy. Nat Neurosci., vol. 5, n. 11, p. 1111-1113, 2002.

SCHACHTEL, E.G. On memory and childhood amnesia. Psychiatry, n. 10, p. 1-26, 1947.

SCHEDLOWSKI, M.; WIECHERT, D.; WAGNER, T.O.; TEWES, U. Acute psychological stress increases plasma leves of cortisol, prolactin and TSH. Life Sci, n. 17, p. 1201-1205, 1992.

SCHELLING, G. Effects of stress hormones on traumatic memory formation and the development of posttraumatic stress disorder in critically ill patients. Neurobiol Learn Mem, vol. 78, n. 3, p. 569-609, 2002.

SCHNEIDER-RIVAS， S.; RIVAS-ARANCIBIA. S.; VAZQUEZ-PEREYRA， F.; VAZQUEZ-SANDOVAL, R.; BORGONIO-PEREZ, G. Modulation of long term memory and exctintion responses induced by growth hormone $(\mathrm{GH})$ and growth hormone releasing hormone (GHRH) in rats. Life Sci, vol 56, n. 22, p. 433,441, 1995. 
SCHULKIN, J.; GOLD, P. W.; McEWEN, B. S. Induction of corticotrophin releasing hormone gene expression by glucocorticoids: implications for understanding the states of fear and anxiety in allostatic load. Psychoneuroendocrinology, n. 23, p. 219-243,1998.

SCHWARTZ, J.; CHERNY, R. Intracelular communication within the anterior pituitary influencing the secretion of hypophysial hormones. Endocrine Reviews, vol. 13, n. 3, p. 453$475,1992$.

SIAUD, P.; MANZONI, O.; BALMEFREZOL, M.; BARBANEL, G.; ASSENMACHER, I.; ALONSO, G. The organization of prolactin-like-immunoreactive neurons in the rat central nervous system. Light and electron-microscopic immunocytochemical studies. Cell Tissue Res, vol. 255, p. 107-115, 1989.

SILVA, E.J.; FELICIO, L.F.; NASELlO, A.G.; ZAIDAN-DAGLI, M.; ANSELMOFRANCI, J.A. Prolactin induces adrenal hypertrophy. Braz J Med Biol Res, vol. 37, n. 2 p.193-199, 2004.

SOBRINHO, L. G. Prolactin, psychological stress and environment in humans: adaptation and maladaptation. Pituitary, vol. 6, n. 1, p. 35-39, 2003.

TAYLOR, M.; SAMSON, W. K. A possible mechanism for the action of adrenomedullin in brain to stimulate stress hormone secretion. Endocrinology, vol.145, n. 11, p.4890-4896, 2004.

TORNER, L.; NEUMANN, I. D. The brain prolactin system: involvement in stress response adaptations in lactation. Stress, vol. 5, n. 4, p. 249-257, 2002.

THOMPSON, S. A., Localization of immunoreactive prolactin in ependyma and circumventricular organs of rat brain. Cell Tissue Res, vol. 225, p. 79-93, 1982.

THORNTON, P. L.; INGRAM, R. L.; SONNTAG, W. E. Chronic (D-Ala2)-growth hormone releasing hormone administration attenuates age-related deficits in special memory. $J$ Gerontol A Biol Sci Med Sci, vol 55, n. 2, p. 106-102, 2000.

TREMONT, G.; STERN, R.A. Use of thyroid hormones to diminish the cognitive side effects of psychiatric treatment. Psycopharmocol Bull, vol. 33, n. 2, p. 273-280, 1997.

TRYON, WW, 1982. A simplified time-series analysis for evaluating treatment interventions. J Appl Behav Anal, vol. 15, p. 423-429, 1982

TSIGOS, C.; CHROUSOS, G.P. Hypothalamic-pituitary-adrenal axis, neuroendocrine factors and stress. - J Psychosom Res. Oct;53 n.4 pp 865-871, 2002

UEDO, N.; ISHIKAWA, H.; MORIMOTO, K.; ISHIHARA, R.; NARAHARA, H.; AKEDO, I.; IOKA, T.; FUKUDA, S. Reduction in salivary cortisol level by music therapy during colonoscopic examination. Gastroenterology, vol. 51, n. 56, p. 451,453, 2004.

URSIN, H.; BAADE, E., LEVINE, S. (eds) Psychobiology of Stress: A study of coping men. New York: Academic Press, 1978. 
VALLE, W.; SPIESS, J.; RIVIER, C.; RIVIER, J. Characterization of a 41-residue ovine hypothalamic peptide that stimulates secretion of corticotrophin and beta endorphin . Science, n. 213 , p. $1394,1981$.

VAN DE KAR, L. D.; BLAIR, M. L. Forebrain pathways mediating stress-induced hormone secretion. Front Neuroendocrinol, vol. 20, n.1, p.1- 48, 1999.

VERA-LASTRA, O.; JARÁ, L. J.; ESPINOZA, L. R. Prolactin and automimmunity. Autoimmunity Reviews, vol 1, n. 6, p. 360-364, 2002.

XAVIER, G.F. in: Neuropsicologia Nitrini Caramelli Mansur (ed) p. 108, 1996.

YEHUDA, R.; KAHANA, B.; BINDER-BRYNES, K.; SOUTHWICK, S.M.; MASON, J.W.; GILLER, E.L. Low urinary cortisol in holocaust survivors with TSTP. Am J Psychiatry, n. 152, p. 982-986, 1995.

YOUNG, L.C. On randomness in ordered sequences. Annals of Mathematical Statistics, vol. 12, p. 153-162, 1941.

WEISS, D.S.; MARMAR, C.R.; SCHLENGER, W.E.; FAIRBANK, J.A.; JORDAN, B.K.; HOUGH, R.L.; KULKA, R.A. The prevalence of lifetime and partial stress disorder in Vietnam Theater veterans. Journal of Traumatic Stress , vol. 5, n. 3, p. 365-376, 1992.

WANG, S.; MASON, J. Elevation of serum T3 levels and their association with symptoms in World War II with veterans combat-related with Post Stress Traumatic Disorder: replication of findings in Vietnam Combat Veterans. Psychosomatic Medicine, n. 61, p. 131-138, 1999.

WHALIN, A.; WAHLIN, T.B.; SMALL, B.J.; BACKMAN, L. Influences of thyroid stimulating hormone on cognitive functioning in very old age. J Gerontol B Psychol Sci Soc Sci, vol 53, n. 4, p. 234-239, 1998.

WHYBROW, P.C.; PRANGE, A. J. Jr. A hypothesis of thyroid-catecholamine-receptor interactions. Its relevance to affective illness. Arch Gen Psychiatry, vol 38, n. 1, p. 106-113, 1981.

WILSON, J. H. Prolactin in rats is attenuated by conespecific touch in a novel environment. Cog Affect Behav Neurosci, n. 2, p. 199-205, 2001.

WINER, L.M.; SHAW, M.A.; BAUMAN, G. Basal growth hormone levels in man: new evidence for rithmicityof growth hormone secretion. J Clin Endocrinol Metab n. 70, p. 1678$1686,1990$.

WOLF, T. O. HPA-axis and memory, Best Practice \& Research Clinical Endocrinology and Metabolism, vol 12, n.. 8, p. 287-299, 2003.

WURTMAN, R.J. Stress and adrenocortical control of epinephrine syntesis. Metabolism, vol 51, n. 6, Suppl (1), p.11-14, 2002. 
WÜST S.; FEDERENKO, I.S.; VAN ROSSUM, E.F.; KOPER, J.W.; HELLHAMMER , D.H.. Habituation of cortisol responses to repeated psychosocial stress - further characterization and impact of genetic factors. Psychoneuroendocrinology, vol. 30, n. 2, p. 211, 200, 2005. 
Por que tanta tristeza diante do último lampião da rua?

(Mário Quintana)

8. ANEXOS 
INSTITUTO NACIONAL DE PESQUISA E TERAPIA REESTRUTURATIVA VIVENCIAL PERES

RUA MAESTRO CARDIM, 887-PARAISO- SÄO PAULO- SP-BRASIL

CEP : : 01323-001 - Fone (0xx11) 3288-6523/Fax(0xx11) 3284-8929

São Paulo,03 de Agosto de 2000

IImo.(a).Sr.(a).

Dr. Régis Cavini Ferreira

O Comitê de Ética em Pesquisa do Instituto Nacional de Pesquisa Reestruturativa Vivencial Peres, reunido no dia $\mathbf{0 3 / 0 8 / 2 0 0 0}$ no cumprimento de suas atribuições, após revisão do seu projeto de pesquisa "Respostas Autonômicas e Neuroendócrinas à Recuperação de Memórias traumáticas" emitiu parecer segundo os termos da Resolução 196/96 do Ministério da Saúde, enquadrando-o na seguinte categoria :

[X ] Aprovado ( Inclusive o TCLE);

[ ] Com pendência (há modificações ou informação relevante a serem atendidas em 60 dias, enviar as alterações em duas cópias);

[ ] Retirado (por não ser reapresentado no prazo determinado);

[ ] Não aprovado

Em obediência ao que determina a Resolução 196/96, Solicitamos a V.S informar sobre o andamento do seu Projeto a cada seis meses, isto é, se já foi concluído, se foi Suspenso ou se ainda está em andamento; neste último caso Comunicar qual o tempo previsto para conclusão do mesmo.

Contando com a sua colaboração, subscrevemo-nos.

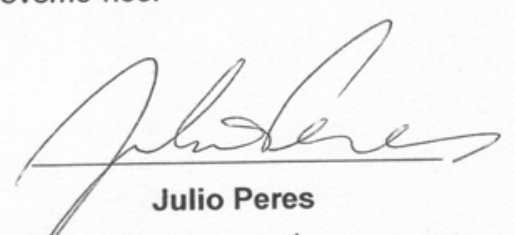

Presidente do Comitê de Ética em Pesquisa 
Tabela VII

Resultados dos testes psicológios e cronotipagem

\section{Sujeito SCID/DSM-IV HAM-A BDI Cronotipo}

$\begin{array}{llcll}\mathbf{1} & \text { TAG-300.02 } & 12 & 0 & \mathrm{M} \\ \mathbf{2} & \text { FSO-300.23 } & 17 & 8 & \mathrm{M} \\ \mathbf{3} & \text { Sem Diagnóstico } & 7 & 0 & \mathrm{M} \\ \mathbf{4} & \text { Sem Diagnóstico } & 0 & 3 & \mathrm{M} \\ \mathbf{5} & \text { TAG-300.02 } & 11 & 8 & \mathrm{M} \\ \mathbf{6} & \text { FSO-300.23 } & 1 & 1 & \mathrm{M}\end{array}$

TAG - Transtorno de Ansiedade Generalizada FSO - Fobia Social

M - matutino 


\section{Tabela VIII - comparação entre as vivências}

\section{Sujeito Emoções, sensações e sentimentos experimentados durante a vivência}

tristeza, raiva, solidão, medo, frustração, rejeição, sensação de perda

medo, constrangimento, frustração, desproteção, confusão mental

tristeza, medo, impotência, culpa, vergonha, angústia, insegurança, baixa auto-estima

tristeza, raiva, abandono, solidão, impotência

raiva, tristeza, culpa, medo, orgulho, horror, sensação de poder

medo, raiva,culpa, solidão, egoismo, dúvida, arrependimento, ansiedade
Tempo (min)

45-70

38-79

38-75

$50-90$

41-75

45-105 